UNIVERSIDADE DE SÃO PAULO

FACULDADE DE EDUCAÇÃO

VIVIANE BARBOZA FERNANDES

O quilombo e a escola de Barro Preto, em Jequié, Bahia: vicissitudes e sentidos de identidade 
VIVIANE BARBOZA FERNANDES

\title{
O quilombo e a escola de Barro Preto, em Jequié, Bahia: vicissitudes e sentidos de identidade
}

\author{
Versão Corrigida \\ (Versão original encontra-se na unidade que aloja \\ o Programa de Pós-graduação) \\ Tese apresentada à Faculdade de Educação da Universidade de \\ São Paulo para a obtenção do título de Doutora em Educação. \\ Área de concentração: Psicologia e Educação \\ Orientadora: Prof $^{\mathrm{a}} \mathrm{Dr}^{\mathrm{a}}$ Maria Cecília Cortez Christiano de \\ Souza
}

São Paulo 
AUTORIZO A REPRODUÇÃO E DIVULGAÇÃO TOTAL OU PARCIAL DESTE TRABALHO, POR QUALQUER MEIO CONVENCIONAL OU ELETRÔNICO, PARA FINS DE ESTUDO E PESQUISA, DESDE QUE CITADA A FONTE.

Catalogação na Publicação

Serviço de Biblioteca e Documentação

Faculdade de Educação da Universidade de São Paulo

$371.98 \quad$ Fernandes, Viviane Barboza

F363q O quilombo e a escola de Barro Preto, em Jequié, Bahia: vicissitudes e sentidos de identidade / Viviane Barboza Fernandes; orientação Maria Cecília Cortez Christiano de Souza. São Paulo: s.n., 2017.

251 p.; anexos; apêndice

Tese (Doutorado - Programa de Pós-Graduação em Educação. Área de Concentração: Psicologia e Educação) - - Faculdade de Educação da Universidade de São Paulo. Versão Corrigida.

1. Quilombo 2. Escola 3. Identidade 4. Educação I. Souza, Maria Cecília Cortez Christiano de, orient. 
FERNANDES, V. B. O quilombo e a escola de Barro Preto, em Jequié, Bahia: vicissitudes e sentidos de identidade. 2017. 251 f. Tese (Doutorado em Educação) - Faculdade de Educação, Universidade de São Paulo, São Paulo, 2017.

Aprovado em:

Banca Examinadora

Prof. Dr.

Instituição:

Julgamento:

Prof. Dr.

Instituição:

Julgamento:

Prof. Dr.

Instituição:

Julgamento

Prof. Dr.

Instituição:

Julgamento:

Prof. Dr.

Instituição:

Julgamento: 
À minha mãe Maria Clarice,

a Manuela, minha sobrinha, e aos participantes desta pesquisa. 


\section{AGRADECIMENTOS}

Aos participantes desta pesquisa.

À minha mãe Maria, sempre parte de mim.

Ao meu pai, Seu Vavá.

À minha tia Noélia e seus filhos.

Às minhas irmãs, Katita, Preta e Dilma.

Ao meu irmão e amigo Leo.

À minha irmã Elizangela pelo companheirismo na vida e contribuições a esse trabalho.

Ao meu anjo amigo e Pimpão Beto Bolsam.

À Tiago pelo apoio e otimismo.

Às minhas sobrinhas Gabi, Isa Maria, Iasmim e aos sobrinhos Tay, Edu e Biel.

À querida professora Maria Cecília pelo carinho, apoio, incentivo e contribuições.

Às professoras Eliane e Lia pelas valiosas contribuições nas bancas de qualificação e defesa desse trabalho.

Às professoras Lourdes e Angela pela presença e contribuições preciosas na banca de defesa. Aos amigos Carlinhos, Lia, Jailson, Juliana, Rosangela, Sônia Maria, Marlene e Meire.

Ao amigo Clodoaldo, pela amizade e colaboração ao "Abstract" deste trabalho.

Às minhas queridas amigas Virginia, Leca e Katia Fukushima.

À minha amiga "negritude" Janaina Bastos, pelo carinho e risos.

Aos meus companheiros de quatro patas Àquilis, Nina, Sofia, Julia, Kiara, em especial, à Manuela.

Aos amigos Chica, Vovóia e Molequinho.

Aos amigos que fiz nesse caminho de doutorado, em especial, Nana, Priscila, Glória, Tiago Bodê.

Aos funcionários da Pós-Graduação da Faculdade de Educação Da USP, em especial a Antônio. À professora Claudia Adametes, que revisou este trabalho.

À Secretaria de Educação do Estado de São Paulo pelo incentivo financeiro.

Aos alunos e profissionais da Escola Quilombola Colégio Estadual Doutor Milton Santos. 


\section{RESUMO}

FERNANDES, V. B. O quilombo e a escola de Barro Preto, Jequié, Bahia: vicissitudes e sentidos de identidade. 2017. 251 f. Tese (Doutorado) - Faculdade de Educação, Universidade de São Paulo, São Paulo, 2017.

Esta tese tem como base pesquisa realizada em uma comunidade quilombola urbana, denominada Barro Preto, situada em Jequié, cidade do sudoeste da Bahia, em 2015. O lócus basilar da investigação constituiu-se na escola pública de ensino fundamental estabelecida na comunidade, o Colégio Estadual Doutor Milton Santos. O estudo apoiou-se principalmente em entrevistas realizadas com sujeitos pertencentes à comunidade escolar e ao seu entorno - professores, gestores, alunos e moradores. No período compreendido pela pesquisa foi possível acompanhar, de forma privilegiada, o processo pelo qual a comunidade e a escola se definiram, respectivamente, como quilombo e como escola quilombola. $\mathrm{O}$ objetivo principal deste trabalho consistiu assim em investigar e interpretar diferentes sentidos de identidade produzidos pelos sujeitos envolvidos em tal processo. A abordagem metodológica situou-se em uma perspectiva qualitativa, mediante realização de entrevistas, produção de testemunhos e memórias, organização de grupo focal e análise de conteúdo dos discursos recolhidos. Considerando a função proeminente da escola no processo de construção de identidade, buscou-se compreender e analisar as dinâmicas, conflitos e as vicissitudes vividas neste percurso. Como resultado, constatamos que a identidade quilombola, neste caso particular, pode ser compreendida através dos sentidos produzidos pelos sujeitos em um contexto que os impeliu a refletir e a pensar sobre o significado de "ser negro" e de "ser quilombola". Esses sentidos, que se estendem para além da dimensão étnico-racial, para efeito de análise foram elencados em seis categorias principais - território; memória; ancestralidade; corpo; ato político e religião -, por meio das quais organizamos a apresentação dos temas, a discussão teórica e a análise dos dados. Evidenciou-se, nas falas dos sujeitos, que existem, entre uma parcela significativa dos moradores da comunidade (e também dentro da própria escola), tensões relacionadas à autoidentificação, dados os estereótipos e preconceitos em torno do "ser negro" e "ser quilombola". Diante dessa realidade, observou-se o papel preponderante desempenhado pela escola no combate ao racismo e na edificação de aportes para construção e afirmação da identidade negra e quilombola na comunidade maior. Em seu processo de tornar-se quilombola, a instituição tem experienciado desafios, tensões, sucessos e recuos. Ainda que cerceada pelo racismo, a escola, na pessoa de seus gestores, alunos e professores, empreendeu ações que ecoaram em seu interior e para além dele. As transformações são significativas, pois sinalizam que esse contexto escolar tem influenciado positivamente o processo de construção das identidades, especialmente aquelas relacionadas à negritude e ao quilombo. Por isso, a escola é vista pelos moradores como instituição emblemática. Como agente fundamental na afirmação da identidade negra e da identidade quilombola, a escola se configura como pequeno mocambo, onde, em meio a diferenças e conflitos, são tecidas as identificações e os laços que conjugam pertencimento e posicionamento. Uma reverberação evidente desse processo é o grau de criticidade e a forma politizada com que os alunos discutem as relações étnico-raciais.

Palavras-chave: Quilombo. Escola. Identidade. Educação. 


\begin{abstract}
FERNANDES, V. B. The quilombo and the school of Barro Preto in Jequié, Bahia: vicissitudes and senses of identity. 2017. 251 f. Thesis - Faculdade de Educação, Universidade de São Paulo, São Paulo, 2017.

This thesis is based on research done in an urban quilombola community, denominated Barro Preto, located in Jequié, city of southwestern Bahia, in 2015. The basilar locus of the investigation was constituted in the public school of elementary education established in the community, the Colégio Estadual Doutor Milton Santos. The study was supported mainly based on interviews with subjects belonging to the school community and its surroundings - teachers, managers, students and residents. During the period covered by the research, it was possible to follow, in a privileged way, the process by which the community and the school defined themselves, respectively, as a quilombo and a quilombola school. The main objective of this work was to investigate and interpret different senses of identity produced by the subjects involved in such a process. The methodological approach was based on a qualitative perspective, by means of interviews, production of testimonials and memories, focus group organization and content analysis of the discourses collected. Considering the prominent function of the school in the process of identity construction, it was sought to understand and analyze the dynamics, conflicts and vicissitudes experienced in this course. As a result, we verified that the quilombola identity, in this case, can be understood by the senses produced by the subjects in a context that impelled them to reflect and to think about the meaning of "being black skinned" and "being quilombola". These meanings, which extend beyond the ethnic-racial dimension, for analysis purposes have been listed in six major categories - territory; memory; ancestry; body; political act and religion - through which we organize the presentation of the themes, the theoretical discussion and the analysis of the data. It was evidenced, in the subjects' speeches, that there are tensions related to self-identification, given stereotypes and prejudices about "being black skinned" and "being quilombola", among a significant portion of the community residents (and also within the school itself). Faced with this reality, it is observed the preponderant role played by the school in the fight against racism and in the edification of aids for the construction and affirmation of the black and quilombola identity in the larger community. In its process of becoming a quilombola, the institution has experienced challenges, tensions, successes and draw backs. Although curtailed by racism, the school, in the person of its managers, students and teachers, undertook actions that echoed within and beyond it. The transformations are significant, as they indicate that this school context has positively influenced the process of constructing identities, especially those related to black awareness and the quilombo. Therefore, the school is seen by the residents as an emblematic institution. As a fundamental agent in the affirmation of the black identity and the quilombola identity, the school is configured as a small mocambo, where, amid differences and conflicts, the identifications and bonds that combine belonging and positioning are woven. An obvious reverberation of this process is the degree of criticality and the politicized way in which students discuss ethnic-racial relations.
\end{abstract}

Keywords: Quilombo. School. Identity. Education. 


\section{SUMÁRIO}

INTRODUÇÃO ................................................................................................................................. 9

1. CAMINHOS DA PESQUISA.......................................................................................... 20

1.1. Estruturando a pesquisa de campo........................................................................................ 20

1.2. Por que uma escola quilombola no quilombo de Barro Preto?.......................................... 21

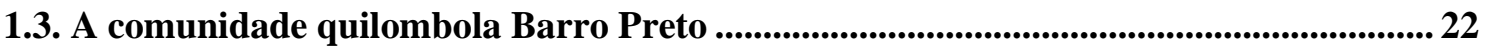

1.4. A escola Milton Santos ......................................................................................................... 23

1.5. Os participantes da pesquisa ...................................................................................................... 23

1.6. Entrada em campo …………………............................................................................................ 24

1.7. Análise dos dados ............................................................................................................... 26

2. CONTEXTUALIZANDO QUILOMBOS E O QUILOMBO URBANO DE BARRO PRETO 28

2.1. Quilombo e Comunidade remanescente de quilombo....................................................... 28

2.2. Quilombos urbanos e territórios negros................................................................................ 39

3. QUILOMBO: "O GRANDE NEGRO" ..............................................................................5

3.1. Implicações de "ser negro" no Brasil no processo de assumir-se quilombola ............... 59

3.2. Identidade quilombola: uma identidade étnica e racial..................................................... 71

4. IDENTIDADE QUILOMBOLA: UMA IDENTIDADE EM PROCESSO......................... 84

4.1. Identidade e memória ........................................................................................................... 87

4.2. Identidade e território...........................................................................................................96

4.3. Identidade e ancestralidade..................................................................................................... 108

4.4. Identidade e religião......................................................................................................... 122

4.5. Identidade, corpo e ato político ............................................................................................ 131

5. EDUCAÇÃO ESCOLAR QUILOMBOLA NO QUILOMBO ........................................... 162

5.1. Educação Escolar Quilombola ......................................................................................... 162

5.2. Vicissitudes de uma escola no processo de tornar-se uma escola quilombola ..............170

CONSIDERAÇÕES FINAIS ......................................................................................... 220

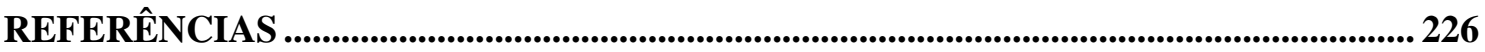

APÊNDICE A - Carta de apresentação da pesquisa ............................................................... 243

APÊNDICE B - Termo de Consentimento Livre e Esclarecido ............................................. 244

APÊNDICE C - Roteiro de Entrevista com as gestoras da escola......................................... 245

ANEXO A - Imagens da comunidade Barro Preto................................................................. 246

ANEXO B - Imagens do Colégio Estadual Dr. Milton Santos............................................. 249

ANEXO C - Certidão de reconhecimento de Barro Preto como comunidade remanescente de quilombo 


\section{INTRODUÇÃO}

A introdução é a parte de um texto de pesquisa em que o pesquisador pode falar um pouco de si, de suas escolhas e vivências. Decerto, há muitos trabalhos em que não há conexão entre a subjetividade do pesquisador e o objeto ou campo de pesquisa, no entanto, quase sempre a escolha do objeto a ser investigado constitui algo que, de alguma forma, dialoga com a compreensão de seu próprio existir.

O meu despertar pelo estudo das relações étnico-raciais deu-se após o término de minha graduação, embora já estivesse, há muito, atravessada por essas relações, como todos os brasileiros. Como filha de pai negro e mãe branca, carregava o rótulo de "mestiça" e, nas artimanhas da mestiçagem percebia, desde criança, discriminação na forma em que era tratada, ora mais amena ora mais aguda. $\mathrm{Na}$ adolescência, sentia grande indignação ao observar as desigualdades entre brancos e negros. Lembro-me de uma conversa com minha irmã em que falávamos que gostaríamos de pintar todos os brancos racistas de preto e escrever na testa de cada um a letra $\mathrm{B}$, de branco. Na conversa falávamos "Ah, mas eles não seriam vistos como nós negros, mas como, de fato são: brancos; e o castigo será terem em seu corpo a cor que desprezam e serem oprimidos, tanto quanto oprimiram os negros, por tantos e tantos anos". Devo reconhecer esse sentimento como um dos efeitos do ressentimento social, produzido pelo racismo.

Com o tempo, comecei a me questionar sobre a forma pela qual o racismo se estabelece e como surge o racista. E tudo foi se complicando ainda mais, até que um dia, para aliviar o coração, deixei de pensar, "descansei do racismo"; e fiquei assim, descansando, até a minha entrada na faculdade quando, no primeiro dia de aula, encontrei o segundo professor negro de minha vida. Lembro que, nesse dia, me senti muito feliz e pensei que as coisas poderiam mudar: “Um professor negro na faculdade!”. (Como a representação é importante!). Diante da maioria de professores e alunos brancos, esse encontro fez com que a eu imaginasse como possível a transformação da hierarquia racial existente e a possibilidade de ocupação de espaços que a sociedade proíbe aos negros.

Após a conclusão do curso, em 2005, fui procurar bases teóricas para compreender melhor as interfaces entre relações étnico-raciais e educação, já como professora que teria que lidar, em sala de aula, com essas questões. No ano seguinte, cursei a disciplina "Teorias Educacionais com Aportes nas Africanidades”, com a professora Petronilha Beatriz Gonçalves e Silva, no intuito de instrumentalizar minha prática. Atuando como professora, na Secretaria 
Estadual de Educação do Estado de São Paulo, pude perceber mais fortemente o quanto a dinâmica do sistema escolar veicula, silenciosa e cotidianamente, o racismo. Após dois anos de atividade docente, ingressei no Mestrado em Educação, na UNESP (Universidade Estadual Paulista (Unesp)/Araraquara (SP). Minha pesquisa de mestrado teve como objetivo compreender a dinâmica das relações étnico-raciais no contexto escolar, investigando as consequências do racismo na formação da identidade e nas relações cotidianas dos alunos. Buscou-se, também, investigar o conhecimento dos professores a respeito da Lei 10.639/2003 e a forma como lidavam com situações racistas. Realizei a pesquisa em uma escola de periferia da cidade vizinha, São Carlos (SP). Em 2011, um ano após a defesa da Dissertação, passei a atuar como tutora presencial do curso de "Especialização para a Educação das Relações Étnicoraciais", junto à UFSCar (Universidade Federal de São Carlos). Neste curso, havia o módulo “A face quilombola no Brasil", no entanto, nenhuma das discussões abordava o tema específico da educação escolar quilombola - esta observação gerou minhas reflexões a respeito das relações entre quilombo e educação, desdobradas nesta pesquisa de Doutorado, iniciada em 2013.

Nossa perspectiva é a de que temas vinculados às relações étnico-raciais dizem respeito à busca de nossa própria identidade, o que envolve "Compreender melhor e apreender melhor a mim mesmo: dois movimentos complementares, e sem dúvida indissociáveis. É precisamente pelo prazer de descobrir as distâncias e as diferenças que atingimos o prazer que nos proporciona o que está próximo de nós e nos é próprio" (LOPES,1994, p. 168). Trata-se de um olhar sobre traços que compõem as identidades brasileiras e, no caso específico desta pesquisa, de um olhar sobre nossas marcas africanas.

Este trabalho resulta, portanto, da necessidade de compreender efetivamente, como docente e pesquisadora, meu lugar de inserção no universo escolar, a partir do recorte das relações étnico-raciais. Muito embora o lócus de pesquisa não seja minha atuação, acredito que a compreensão destas questões em diferentes realidades auxiliam na elaboração de ferramentas eficazes de intervenção, no sentido da desconstrução do racismo e na construção positiva das identidades. O contexto escolar quilombola poderia, ainda, nos oferecer discussões e práticas com potencial de orientarem ações concernentes à educação para as relações étnico-raciais em âmbito nacional.

Nas últimas décadas, as discussões em torno de questões que envolvem identidades, diferenças e políticas públicas de promoção de equidade social têm se intensificado em decorrência, sobretudo, da atuação de movimentos sociais contemporâneos que engendram 
novas interpretações conceituais. Com seus "discursos e práticas desestabilizadoras", os movimentos possibilitam que as desigualdades sociais sejam percebidas na articulação entre as ideologias e as dimensões subjetivas, históricas, culturais, políticas e econômicas (MIRANDA, 2012). Denuncia-se que o abismo social entre determinados grupos advém da hierarquização social reatualizada, cotidianamente, através do racismo presente em toda a estrutura institucional brasileira e se desafia a ordem social normatizadora de identidades que assegura, por sua vez, bens materiais e simbólicos à população branca em detrimento das populações negra e indígena.

Nesse sentido, constituindo instrumento utilizado para a reprodução e manutenção das desigualdades sociais, a educação se torna a principal esfera de luta desses movimentos e o sistema educacional passa a ser questionado a partir de um olhar crítico que permite desnudar a violência simbólica impingida intergeracionalmente a negros e indígenas através de currículos, livros didáticos e outros dispositivos do contexto escolar.

A escola não é o berço do racismo, mas por ser espaço de formação e via de mobilidade social tem sido colocada a serviço dos grupos detentores do poder, de forma a domesticar e conformar os indivíduos a determinados papéis sociais; em outras palavras, o espaço escolar não é racialmente neutro, pois atua na produção de significados que moldam as formas como as relações se estabelecem (SILVÉRIO, 2010). Ao produzir discursos que hierarquizam as diferenças, a escola colabora para a reprodução de estigmas sociais e isso ocorre através de produções simbólicas que inferiorizam o "ser negro" e que, ao serem veiculadas no ambiente escolar, povoam o imaginário social, fazendo com que as distintas condições sociais sejam percebidas como naturais, em virtude de uma suposta inferioridade intrínseca da pessoa negra. Essas produções alimentam falsos sentidos, na medida em que alienam, dificultam ou impedem uma leitura crítica da realidade social, mas são extremante racionais e eficazes em seus propósitos. O projeto histórico que há de escola pública no Brasil acaba por atender à reprodução ideológica, corroborando para a morte simbólica e concreta da população negra.

Sabemos como, no plano concreto da vida cotidiana, a naturalização do racismo tem conduzido a desigualdades de acesso e de perspectivas. Para Rosemberg (2017, p. 133), a reflexão sobre a desigualdade de acesso no âmbito da educação deve fazer a conexão entre as dimensões socioeconômica e de pertencimento racial: “[...] quando analisamos dados educacionais de pretos e pardos, observamos que, de modo consistente, seus perfis de desvantagens (acesso, permanência e sucesso) convergem entre si, ao mesmo tempo em que divergem dos brancos". 
Compreendemos que o racismo deve ser pensado em sua vertente mais "incrustadora", a vertente institucional. Nessa perspectiva, a mesma autora argumenta que é necessário refletir sobre o modo com que o racismo se efetua no nível institucional e extrapola as relações interpessoais, ou de humilhação social. Segundo Cerqueira e Moura (2013), as instituições que compõem o Estado e a sociedade reforçam estigmas e vitimizam a população negra através de ações cotidianas e difusas. Dessa maneira, somado a outras esferas de produção do racismo, o racismo institucional produz os altos índices de morte da população negra: “[...] para cada homicídio de não negro no Brasil, 2,4 negros são assassinados, em média" (CERQUEIRA e MOURA, 2013, p. 03). Segundo os autores, o racismo mata por meio da banalização da violência, como se a vida de um negro valesse menos que a de um branco, como constatamos nas mais diversas mídias, nos âmbitos nacional. Há, ainda, a morte simbólica que, de um lado, limita ou bloqueia o acesso a oportunidades de trabalho e de crescimento profissional, e, de outro lado, incide negativamente na autoestima das pessoas negras, inibindo suas potencialidades e limitando suas aspirações.

Por muito tempo, em função de seus conteúdos eurocêntricos, a instituição escolar se produziu como um espaço de "não lugar" para o negro - é nesse sentido que os movimentos sociais de negros e de quilombolas propõem que a educação seja pensada para e pelos sujeitos a quem serve. Suas ações propõem um repensar sobre as relações étnico-raciais, as identidades individuais e coletivas, o sentido da educação e a função social da escola, compreendida como espaço privilegiado de desconstruções de estereótipos e preconceitos, no combate ao racismo. É nesse processo que uma narrativa a contrapelo se elabora, inserindo no campo educacional as questões da diversidade, da incorporação da história livre de distorções, da centralidade na cultura e da consideração das diferentes identidades presentes na escola.

O modo de se pensar políticas públicas no campo educacional ganha, assim, novos contornos, devendo as mesmas serem formuladas em diálogo com os grupos que representam, com ênfase em suas diferenças. Esse quadro diz respeito ao reposicionamento de negros, indígenas e quilombolas no território escolar e à produção de um processo de desconstrução ideológica, na medida em que as mudanças ensejam que estes segmentos sociais se pensem a partir dos seus próprios valores, história e cultura, o que não se faz sem desafios e contradições.

A partir dessa perspectiva, a pressão exercida pelos referidos movimentos sociais levou à inserção de conteúdos relativos à diversidade na LDB e a alterações nesse dispositivo, com a criação das Lei 10.639/2003 e da Lei 11.645. Estas leis serviram de base para o estabelecimento das Diretrizes Curriculares Nacionais para a Educação das Relações Étnico-Raciais. Com 
relação à educação escolar quilombola, esta foi definida pela primeira vez, em 2010, nas Diretrizes Curriculares Nacionais Gerais para a Educação Básica:

\begin{abstract}
Art. 41. A Educação Escolar Quilombola é desenvolvida em unidades educacionais inscritas em suas terras e cultura, requerendo pedagogia própria em respeito à especificidade étnico-cultural de cada comunidade e formação específica de seu quadro docente, observados os princípios constitucionais, a base nacional comum e os princípios que orientam a Educação Básica brasileira (BRASIL, 2010a).
\end{abstract}

A partir de então, outros dispositivos jurídicos se sucederam até a formulação, em 2012, das Diretrizes Curriculares Nacionais para a Educação Escolar Quilombola na Educação Básica. A proposta de uma modalidade específica de educação para comunidades remanescentes de quilombos trouxe algumas questões: o que são estas comunidades? Onde se localizam? No campo educacional, esses questionamentos lançam a necessidade de entender a trajetória histórica do conceito de quilombo na dimensão concreta da existência, no passado e no presente: sua apropriação e ressignificação nos meios jurídico, antropológico e social.

Neste ponto, é fundamental considerar que durante os períodos Colonial e Imperial houve a criminalização do quilombo, definido legalmente, em 1740, pelo órgão oficial Conselho Ultramarino como: "Toda habitação de negros fugidos, que passem de cinco, em parte despovoada, ainda que não tenham ranchos levantados e nem se achem pilões nele". Embora ainda permaneça no imaginário social, essa definição foi superada no século XX, por meio de estudos no campo da historiografia, a exemplo da obra de Édson Carneiro (1958), que definiu quilombo como luta social. Esta acepção foi apropriada pelo movimento negro a partir dos anos 1950, mas foi apenas nos anos 1970, com a obra de Abdias do Nascimento, "Quilombismo", que o termo ganhou maior abrangência, como fenômeno social, passando a conjugar manifestações culturais, religiosas, musicais, etc.

Outra acepção de destaque, apresentada por Clóvis Moura (1981), é a de quilombo como resistência política contra o sistema escravista, definição que ressaltou o protagonismo negro, colaborando para uma significação positiva do termo. Essas produções, concomitantes à luta política do movimento negro, enfatizam o quilombo como ícone de identidade e resistência negra. O termo volta a ser inserido no âmbito jurídico, com seu sentido já ressemantizado, na Constituição de 1988: “Aos remanescentes das comunidades dos quilombos que estejam ocupando suas terras é reconhecida a propriedade definitiva, devendo o Estado lhes emitir os títulos respectivos" (BRASIL, 1988).

Um segundo momento que marca essa ressemantização é o contexto de luta dos movimentos camponeses regionalmente organizados, principalmente no Pará e Maranhão, que reivindicam a abrangência do dispositivo jurídico constitucional a comunidades negras rurais, 
considerando a diversidade de suas formações (terras de preto, terras de santos, entre outras) e diferentes modos de uso e acesso à terra (doações, recebidas por serviços prestados, compradas etc). Nesse contexto há ênfase na associação entre território e quilombo (ARRUTI, 2017). Diante dessas questões, a Associação Brasileira de Antropologia propôs a seguinte definição para o termo:

\begin{abstract}
Contemporaneamente, portanto, o termo quilombo não se refere a resíduos ou resquícios arqueológicos de ocupação temporal ou de comprovação biológica. Também não se trata de grupos isolados ou de uma população estritamente homogênea. Da mesma forma nem sempre foram constituídos a partir de movimentos insurrecionais ou rebelados mas, sobretudo, consistem em grupos que desenvolveram práticas cotidianas de resistência na manutenção e reprodução de seus modos de vida característicos e na consolidação de um território próprio (O’DWYER, 2008, p. 02).
\end{abstract}

Os remanescentes de quilombos passam a ser considerados como grupo étnico diferenciado e formador da sociedade brasileira. Segundo Arruti (2009; 2017), partindo dessa interpretação, o Estado passa a atender essas comunidades por meio de políticas públicas de caráter universal, considerando sua vulnerabilidade social; somente em um segundo momento é que essas políticas se tornam diferenciadas, em conformidade com as especificidades identitárias, históricas e socioculturais dessas comunidades. Considerando essas particularidades, é estabelecido em 2003 o Decreto $n^{\circ} 4.887 / 2003$, no qual as comunidades remanescentes de quilombos são entendidas como "[...] grupos étnico-raciais, segundo critérios de autoatribuição, com trajetória histórica própria, dotados de relações territoriais específicas, com presunção de ancestralidade negra relacionada com a resistência à opressão histórica sofrida." (BRASIL, 2003). Esse decreto trouxe avanços nos planos político, conceitual e do direito, pois torna possível a autodeterminação e regulariza os procedimentos de identificação, reconhecimento, delimitação, demarcação e titulação dos territórios quilombolas (BRASIL, 2011).

Os debates a respeito do conceito de quilombo persistem nos movimentos sociais e nos meios antropológico, político e jurídico, sendo sua complexidade intensificada mediante a realidade das comunidades quilombolas. As discussões a respeito dessas formações no contexto urbano, sua existência no passado e transposição para os dias de hoje, exemplificam a plasticidade do conceito histórico de quilombo e evidenciam seu caráter processual e sua contínua construção. Assim, "O conceito de quilombo incorpora, também, grupos remanescentes de quilombolas que ocupam áreas urbanas, ultrapassando a ideia de que esses se restringem ao meio rural". 1

\footnotetext{
${ }^{1}$ Ibid., p. 14.
} 
No que concerne à implementação de políticas diferenciadas no campo da educação quilombola: "A implantação da modalidade de educação quilombola insere-se no conjunto mais amplo de desestabilização de estigmas que definiram, ao longo de nossa história, a inserção subalterna da população negra na sociedade e, consequentemente, no sistema escolar." (MIRANDA, 2012, p. 374). É neste lugar que se encontra a comunidade quilombola urbana de Barro Preto, na qual se insere a escola Milton Santos ${ }^{2}$, uma escola quilombola em um quilombo urbano de periferia. Essa comunidade se situa no município de Jequié, no Sudoeste da Bahia, a uma distância de 360 km de Salvador, na zona limítrofe entre a caatinga e a Zona da Mata, com um contingente de 151.820 habitantes (IBGE, 2010). A comunidade foi reconhecida, pela Fundação Cultural Palmares (FCP) ${ }^{3}$, como quilombo urbano, em $2007^{4}$. Neste mesmo ano, a escola foi reconhecida, pelo Ministério de Educação, como instituição de educação quilombola. Ela conta com 783 alunos, oferece turmas da $5^{a}$ série do Ensino Fundamental à $3^{\text {a }}$ série do Ensino Médio, atendendo alunos da comunidade e do seu entorno.

Desde do seu reconhecimento, a escola tem desenvolvido ações que objetivam efetivar a proposta de educação quilombola presente nas Diretrizes Curriculares Nacionais para a Educação Escolar Quilombola da Bahia. Em 2011, a instituição ganhou o selo Nacional de Igualdade Racial ${ }^{5}$ pela realização de oficinas de arte que contemplam as culturas africana e afro-brasileira. Desde 2009, a escola vem desenvolvendo projetos e eventos com o intuito de resgatar a ancestralidade e elevar a autoestima da comunidade escolar, tendo em vista a formação da identidade quilombola.

Ainda que haja o critério da autoatribuição para que uma comunidade seja reconhecida como remanescente de quilombo, frequentemente, a autoidentificação como quilombola não é

\footnotetext{
2 A escola recebeu esse nome em homenagem ao professor Milton Santos (1926-2001), importante geógrafo brasileiro, considerado um dos expoentes do movimento de renovação crítica da Geografia. Ensinou em diversas universidades na Europa, África, na América do Sul e do Norte, etc. No Brasil, lecionou na Universidade Federal da Bahia e na Faculdade de Filosofia, Letras e Ciências Humanas da Universidade de São Paulo. Deixou sua produção registrada em aproximadamente 40 livros e mais de trezentos artigos. Entre seus livros, destacam-se: Pensando o espaço do homem (1982) e Metamorfose do Espaço Habitado (1988).

${ }^{3}$ A Fundação Cultural Palmares (FCP) foi, em 1988, subordinada ao Ministério da Cultura, pela lei $n^{\circ}$. 7.768/88 (22/08/1988); tem como uma de suas atribuições a responsabilidade de encaminhar as demandas das comunidades remanescente de quilombo.

${ }^{4}$ A certidão de reconhecimento de Barro Preto como comunidade remanescente de quilombo foi publicada em março de 2007, no Diário Oficial da União26 - D.O de 13/03/2007 (Anexo C). A comunidade de Barro Preto ainda não recebeu o título definitivo de propriedade.

${ }^{5}$ O Selo de Educação para igualdade Racial foi lançado em 2010 pelo SEPPIR (Secretária de Políticas de Promoção da Igualdade Racial). Destinado a escolas, secretarias municipais e estaduais de educação, o Selo considera iniciativas exitosas na implementação das Diretrizes Curriculares Nacionais para a Educação das Relações Étnicoraciais e para o Ensino de História e Cultura Afro-brasileira e Africana.
} 
algo prontamente partilhado por todos os habitantes dessas comunidades - muitos se familiarizam com o termo "remanescente de quilombo"; designação associada às categorias negra e quilombola, ambas depositárias de um repertório de rótulos e estereótipos negativos, socialmente atribuídos à população negra. Lembremos, ainda, que toda comunidade quilombola, seja urbana ou rural, assim como toda a sociedade brasileira, está sob a influência da ordem social perversa e racista que institui a identidade branca como ideal, em detrimento de outras identidades, como a negra e a quilombola.

Nesse cenário, a escola cumpre papel imperativo dentro de comunidades quilombolas pois, por ser espaço de troca e vivências entre diferentes grupos sociais, é um espaço privilegiado de desconstrução de preconceitos e estereótipos em torno do "ser negro" e "ser quilombola". Por conseguinte, a mesma constitui lugar onde os sujeitos podem desenvolver vínculo com a denominação "remanescente de quilombos" e, ao mesmo tempo, desenvolver sentimento de pertencimento étnico-racial e comunitário.

Pensando no papel preponderante da escola na formação de sujeitos oriundos de comunidades quilombolas, o movimento negro e quilombola empreendeu ações para a criação de dispositivos educacionais específicos para a Educação Escola Quilombola. Esses dispositivos funcionam como políticas de ação afirmativa no combate ao racismo a nível educacional. Entre eles, destaca-se as Diretrizes Curriculares para Educação Escolar Quilombola que determinam e orientam uma série de ações visando a efetivação de uma educação escolar que subverte as ordens conservadora e eurocêntrica da escola.

Estas ordens têm atuado como disruptivas dos laços sociais tradicionais, uma vez que vinculam autoridade e saberes científicos alheios aos saberes dessas comunidades. As Diretrizes Curriculares Nacionais para a Educação Escolar Quilombola na Educação Básica preconizam que a educação escolar quilombola deve ser pautada na articulação entre comunidade escolar e comunidade quilombola, referenciando-se “[...] nos valores das comunidades quilombolas, como a cultura, as tradições, o mundo do trabalho, a terra, a territorialidade, a oralidade e a memória" (BRASIL, 2011, p. 31). A consideração dos saberes da comunidade como parte integrante do currículo possibilita que os sujeitos se vejam como protagonistas de sua própria história.

Nesse sentido, os sistemas de ensino devem incluir em seus currículos a conceituação de quilombo, os avanços e limites do direito dos quilombolas na legislação brasileira e os saberes sobre os movimentos negro e quilombola. Em síntese: "A Educação Escolar Quilombola não pode prescindir da discussão sobre a realidade histórica e política que envolve 
a questão quilombola no país" (BRASIL, 2011, p. 08). Reconhecer o protagonismo negro e quilombola é ponto chave para a construção político-cultural das identidades.

A representação positiva da população negra e quilombola oferece referências positivas que auxiliam no desenvolvimento de autoestima e podem atuar na afirmação da identidade. Como ressalta Silva (2005), a imagem que temos de nós mesmos (autoconceito) se encontra ligada àquela que temos do nosso grupo, o que nos conduz a defendermos ou não os valores do mesmo. A identidade quilombola, tal como a identidade negra, é um posicionamento político, não uma condição dada, mas um “vir a ser" (SOUZA, 1983, p. 77). Ou seja, ser quilombola é tornar-se quilombola. O que supõe responder afirmativamente a uma interpelação coletiva e estabelecer sentimento de pertencimento a um grupo de referência (GOMES, 2003).

Enfatizamos que, embora em alguns casos, a construção da identidade quilombola seja deflagrada de modo objetivo, através da atribuição do rótulo jurídico "remanescente de quilombos", ela é uma identidade de autoatribuição. Portanto, dizer-se quilombola é algo que cabe à própria comunidade, assim como selecionar os elementos que compõem e definem essa identidade. A construção dessa identidade se faz de modo processual, dialógico e coletivo, é tecida em função de apropriações e construções de novas significações, em contraste com indivíduos de outros grupos sociais.

Partindo da ideia de que as novas relações políticas e culturais - estabelecidas a partir do processo de reconhecimento da comunidade - e o processo vivenciado pela escola em se tornar quilombola poderiam levar à emergência de novos sentidos de identidade aos sujeitos envolvidos, procuramos investigar que sentidos de identidade quilombola são produzidos por estes sujeitos. Como objetivos específicos, propomos investigar: a participação da escola na construção dos sentidos de identidade apresentados, especialmente, pelos alunos; desafios enfrentados pela escola no percurso de efetivação de uma educação escolar quilombola; a função social da escola para a comunidade quilombola; e a relação entre identidades negra e quilombola. Cumpre ressaltar que participaram dessa pesquisa quilombolas e não-quilombolas, o que permite transpor para a mesma, o caráter dialógico e contrastivo com que as identidades são construídas.

Esperamos, portanto, que este trabalho contribua com o debate sobre a importância da educação diferenciada para comunidades quilombolas. Com relação aos participantes desta pesquisa, esperamos que a tenham como um pedacinho de suas histórias e que considerem que as interpretações aqui produzidas não são absolutas, pois suas falas guardam, ainda, outros 
sentidos, assim como são, em parte, um retrato do processo contínuo de construção de sua identidade.

Esta pesquisa está estruturada em cinco capítulos, descritos a seguir, construídos visando o diálogo simultâneo, ao longo do texto, entre os dados encontrados no campo e as referências bibliográficas.

O capítulo 1, "Caminhos da pesquisa", foi dedicado à apresentação da metodologia, do campo de pesquisa e de seus participantes.

\section{O capítulo 2, "Contextualizando quilombos e o quilombo urbano de Barro Preto",} divide-se em três tópicos. No primeiro, apresentamos a trajetória histórica dos conceitos de quilombo, discutindo brevemente sua ressemantização. Apoiamo-nos nas formulações de O’Dwyer (2008, 2009), Leite (2000; 2008), Almeida (1996) e, especialmente, de Arruti (1997; 2006). No segundo tópico, procuramos refletir sobre a constituição de quilombos urbanos e sua correlação com territórios negros, dialogando com reflexões de Rolnik (2007) e Carril (2006). No terceiro, apresentamos algumas considerações sobre o processo de reconhecimento da comunidade de Barro Preto como "comunidade remanescente de quilombo".

O capítulo 3, “Quilombo: o grande Negro", está dividido em dois tópicos complementares, nos quais discutimos as construções ideológicas do termo quilombo e a respeito do "ser negro" e "ser quilombola" em suas implicações no processo de assunção do rótulo jurídico "remanescente de quilombos" e na construção da identidade quilombola. Enfatizamos as dimensões étnico-raciais, fundamentais para pensar identidade quilombola dialogando, principalmente, com as reflexões de Poutignat e Streiff-Fenart (1998), Barth (1997), Lima (2008) e Appiah (2010), entre outros.

O capítulo 4, "Identidade quilombola: uma identidade em processo", aborda algumas das categorias que expressam os sentidos de identidade quilombola identificados nas falas dos sujeitos. Trata-se das categorias com as quais dialogamos de forma mais sistemática: memória; ancestralidade; território; corpo; e religião. Subdividimos esse capítulo em cinco tópicos. No tópico Memória, discutimos a construção da memória e sua importância na construção coletiva da identidade. Ressaltamos a memória como elemento importante para a construção da cultura quilombola e do sentimento de pertencimento identitário do grupo, em sua relação com o espaço habitado. Falamos, também, sobre o caráter político da memória, no que concerne às “memórias subterrâneas" (POLLAK, 1989). No tópico Território, abordamos o termo como uma construção simbólica que define a singularidade do grupo, indissociável da identidade. 
Discutimos, ainda, aspectos que envolvem a territorialidade, nos apoiando principalmente nas proposições de Nora (1984) e Haerter (2012). No tópico Ancestralidade, destacamos sua referência na fala dos sujeitos de pesquisa, relacionada aos elementos: território; memória; herança cultural; e corpo negro. Abordamos, a partir das proposições de Slenes (1999), sua importância na reconstituição e criação de práticas e estratégias de resistência e enfatizamos como o conhecimento acerca da trajetória histórica de opressões e resistências que envolvem a população negra no passado e no presente pode irromper em posições de empoderamento e reencontro com a ancestralidade e com o corpo negro. No tópico Religião trazemos as reflexões dos sujeitos acerca da importância desta na constituição da identidade quilombola, considerando sua dimensão histórico-cultural e enfatizamos aspectos que envolvem sua relevância na trajetória histórica da população negra.

No último tópico, Corpo e ato político, considerando o corpo como um marcador importante na identidade quilombola, uma vez que a maioria dos habitantes do quilombo é negra, discutimos as consequências da negação social do corpo negro para o processo de construção da identidade. Ressaltamos a dimensão política da identidade negra, alargando a discussão para aspectos que envolvem cultura e estética negra. Nesse tópico, dialogamos com autores como Costa (2003); Souza (1983); Nogueira (1998); Munanga (2012; 2015); Hall (1996; 2000; 2003) e Gilroy (2007).

O capítulo 5, “Educação Escolar Quilombola”, divide-se em dois tópicos: o primeiro discute o percurso da constituição da Educação Escolar Quilombola como modalidade diferenciada de educação; o segundo discute os desafios, conflitos e sucessos, vivenciados pela escola estudada, no processo de implementação de uma educação quilombola voltada para a valorização da identidade negra e quilombola. Nas considerações finais apresentamos um panorama das temáticas centrais, à luz das questões e objetivos expostos. 


\section{CAMINHOS DA PESQUISA}

\subsection{Estruturando a pesquisa de campo}

A pesquisa de campo foi estruturada a partir de uma abordagem qualitativa, mais especificamente através de um estudo de caso. Os procedimentos de coleta de dados foram fundamentados em autores que discutem esta abordagem: Triviños (1987), Lüdke e André (1986), Martins (2008), que discutem o método de estudo de caso; em Bardin (1987), que trata da análise do conteúdo; e em teóricos que sustentam o trabalho com grupos focais, como Minayo (1998), Neto (1994) e Gatti (2005).

André (2005) nota que o estudo de caso contribui para a descoberta de novos sentidos, permitindo expandir experiências e confirmar o que já se sabia. Luke e André (1986, p. 17) afirmam que "[...] o caso pode ser similar a outros, mas cada caso é ao mesmo tempo distinto, pois possui um interesse próprio, singular"; dessa forma, "o caso se destaca por se constituir numa unidade dentro de um sistema mais amplo. O interesse, portanto, incide naquilo que ele tem de único, de particular".

Seguimos as etapas de pesquisa de acordo com a divisão do estudo de caso proposta por André (2005): a fase exploratória, a fase da coleta de dados e a fase da análise dos dados. Na primeira etapa, o pesquisador entrou em contato com a situação pesquisada, localizando os sujeitos, observando a organização do local de pesquisa, com o intuito de obter informações relevantes para a estruturação das categorias de análise e dos instrumentos de pesquisa. A partir do primeiro contato refletimos sobre as seguintes questões: Como se deu o processo de reconhecimento dessa comunidade como "remanescente de quilombo"? Quais as consequências desse reconhecimento para as práticas no cotidiano escolar?

A respeito do estudo de caso, Martins (2008) nota que, após definição do tema, questões orientadoras e proposições, o autor deverá selecionar técnicas para coleta de dados necessários ao desenvolvimento e conclusões de sua pesquisa. Dessa forma, foram utilizados, como instrumentos para a coleta de dados, a entrevista aberta, a entrevista semiestruturada e o grupo focal, além de observações da escola e da comunidade que constaram no diário de campo. Devido à distância entre o campo de pesquisa e a residência da pesquisadora, algumas informações complementares foram obtidas após a realização da pesquisa de campo, através de e-mail e aplicativo de trocas de mensagens.

A entrevista aberta foi utilizada por dar mais liberdade aos participantes para discorrem sobre o assunto e, dessa forma, explorar mais amplamente o tema pesquisado, além de oferecer 
um rico material a respeito das experiências subjetivas, valores e sentimentos dos entrevistados (MINAYO, 1993; 1996). A entrevista semiestruturada, com roteiro de entrevista, foi utilizada apenas com a diretora e a vice-diretora da escola, de maneira que pudéssemos acessar algumas informações mais precisas sobre o processo de implementação de um currículo quilombola. Nesse tipo de entrevista, segundo Minayo (1996, p. 122), “[...] o entrevistador se libera de formulações pré-fixadas, para introduzir perguntas ou fazer intervenções que visam abrir o campo de explanação do entrevistado ou aprofundar o nível de informações ou opiniões".

Para Minayo (1998), o roteiro de entrevista constitui um instrumento que serve para a orientação do entrevistador, visando ampliar e aprofundar a comunicação entre entrevistador e entrevistado, de modo a permitir a apreensão do ponto de vista dos atores sociais. O roteiro de entrevista contemplou pontos centrais a serem explorados e enfatizados durante a pesquisa, relacionando-se às necessidades e características específicas da situação estudada.

A técnica do grupo focal pode ser compreendida como uma entrevista em grupo, pois oferece informações de caráter qualitativo, se fundamenta na fala e nas opiniões dos participantes, que podem divergir ou não, ocasionando o debate. Esta técnica permite: obter opiniões e perspectivas distintas sobre uma mesma compreensão de especificidades culturais para determinados grupos e para comparabilidade de diversos casos questão; aprofundar aspectos que surgem e que são considerados relevantes; e perceber as representações, comportamentos, costumes, crenças, valores, preconceitos, fatos, entre outros (GATTI, 2015).

O mesmo não constitui uma técnica que exige preparação prévia dos participantes, na medida em "[...] o que se quer é levantar aspectos da questão em pauta considerados relevantes, social ou individualmente, ou fazer emergir questões inéditas sobre o tópico particular, em função das trocas efetuadas (GATTI, 2005, p. 13). O grupo focal possibilita um processo dialógico de produções, em que os sujeitos inseridos em um mesmo contexto produzem significados ao refletirem sobre seu cotidiano. Embora o pesquisador possa intervir e aprofundar questões, os sujeitos também direcionam a dinâmica do grupo.

\subsection{Por que uma escola quilombola no quilombo de Barro Preto?}

Nosso intuito foi pesquisar uma escola em quilombo urbano, um contexto que carece de investigação e o Estado da Bahia está entre os três estados com maior número de comunidades remanescentes de quilombos do Brasil, sendo o primeiro a elaborar Diretrizes Curriculares Estaduais para a Educação Escolar (2013). A princípio, a informação que tínhamos sobre a 
escola Milton Santos era a de que ela implementaria algumas disciplinas específicas para o trato das relações étnico-raciais e efetivação das Diretrizes Curriculares Nacionais e Estaduais para a Educação Escolar Quilombola: Estudos Baianos, no Ensino Fundamental e Cultura Regional, no Ensino Médio. A intenção era acompanhar o desenvolvimento dessas disciplinas e as oficinas desenvolvidas pela escola. Tínhamos como questão de pesquisa investigar os processos educativos na escola quilombola pesquisada e sua influência na formação da identidade quilombola, no entanto, em entrevista com a diretora da escola, foi informado que as referidas disciplinas não haviam sido implementadas.

Assim, os dados obtidos nos levaram a centralizar a questão de pesquisa sobre os sentidos de identidade quilombola. Outro fato que justifica a escolha da escola é o de que seu processo de se tornar quilombola deu-se paralelamente ao processo de reconhecimento da comunidade como remanescente de quilombo. A diretora da escola participou ativamente do processo de reivindicação do reconhecimento da comunidade de Barro Preto como comunidade quilombola e integrou o grupo responsável por encaminhar documentações à Fundação Cultural Palmares, o que levou ao reconhecimento legal da mesma.

\subsection{A comunidade quilombola Barro Preto}

De acordo com dados obtidos a partir do Projeto Político Pedagógico da escola Milton Santos (2012), de documentos obtidos com Francisco, jornalista e membro da comunidade, e do IBGE (2010), a área de Barro Preto abrange vinte e duas ruas, com um total aproximado de 1.600 casas, todas com luz elétrica e $90 \%$ com saneamento básico. A população do bairro é de aproximadamente 7.150 moradores, correspondendo a cerca de $9 \%$ da população da cidade de Jequié; mais de $70 \%$ nascidos na cidade sendo, aproximadamente, $51 \%$ mulheres e $49 \%$ homens. Segundo pesquisa realizada pela escola, a maioria das pessoas da comunidade utilizase da categoria parda para se autoidentificar. Com relação à renda per capita, $80 \%$ apresenta valor inferior a um salário mínimo mensal. A maioria atua em trabalhos informais, há muitos desempregados. A comunidade é atravessada pelo rio Jequiezinho, que se encontra muito poluído.

Trata-se de um bairro muito parecido com outros de periferia: algumas residências com um pouco mais de estrutura - em sua maioria, casas muito próximas umas das outras - e muitas ruas sem calçamento. Ao andar pela comunidade, pude perceber a presença de muitas organizações religiosas, em sua maioria evangélicas; segundo os participantes da pesquisa, 
constatamos a presença de religiões de matriz africana ${ }^{6}$ na comunidade. Os depoimentos foram divergentes com relação ao número de terreiros, mas sugerem, pelo menos, dois no interior da comunidade - um deles com o nome de Marujo -, e outros em suas proximidades. Além da escola Milton Santos, existem 3 escolas de Ensino Fundamental e 1 creche. O bairro possui alguns pequenos comércios, poucos espaços de lazer (apenas três campos de futebol de chão batido) e uma unidade de saúde.

\subsection{A escola Milton Santos}

A escola conta com um número de 720 alunos, oferece turmas da $5^{\text {a }}$ série do Ensino Fundamental à $3^{\mathrm{a}}$ série do Ensino Médio, atendendo alunos oriundos da comunidade e do seu entorno. Conta com um amplo espaço físico: 9 salas de aula; 1 sala de informática; 5 banheiros; 1 sala de secretaria; 1 sala de professores; 1 sala de diretoria; 1 sala multifuncional e 1 cozinha. Há, ainda, uma área externa para as refeições, 1 quadra de esportes e 2 construções (“quiosques"), que constitui um ótimo espaço de convivência para os alunos.

Há uma entrada pelo portão principal e uma saída para carros (estacionamento interno). Em locais no interior da escola e em sua fachada está impresso o símbolo da escola, representado por um rosto negro dentro do mapa do Brasil, rodeado por elementos africanos. Além do nome da escola, o brasão traz estampada a frase: "Escola do Quilombo, no Quilombo!" Nas paredes externas há algumas frases, como: “O mundo é jornada não apenas pelo que já existe, mas pelo que pode efetivamente existir".

\subsection{Os participantes da pesquisa}

Participaram desta pesquisa: a) como membros do grupo focal: quatro alunos do Ensino Médio, Odara, Dudu, Oré, Makbo, e Muraguili uma ex-aluna e funcionária da escola. Os participantes correspondiam aos critérios definidos - estavam na escola há mais de um ano, cursavam ou tinham concluído o Ensino Médio há menos de um ano; havia, entre eles, quilombolas e não quilombolas; b) entrevistados individualmente: duas gestoras, Manuela e Maria, dois professores, Iara e Júlio, e dois moradores do bairro, Carlos e Pedro, respectivamente integrante e ex-integrante da Associação dos Moradores da comunidade

\footnotetext{
${ }^{6}$ IBGE (2010) Disponível em: < https://censo2010.ibge.gov.br/sinopseporsetores/?nivel=st >. Acesso em: 01 nov 2017.
} 
quilombola de Barro Preto). Consideramos que o grupo de entrevistados garante a abrangência de informações diversificadas e relevantes para a questão de pesquisa.

Foram, ainda, utilizadas na discussão: falas de Clarice, funcionária da escola; informações fornecidas por Francisco, jornalista da cidade e morador da comunidade de Barro Preto; e Valter Luiz dos Santos Marcelo, professor na Universidade Estadual do Sudoeste da Bahia, que realizou pesquisa sobre a cidade de Jequié. A pesquisa foi norteada pelas legislações concernentes à ética em pesquisa com seres humanos, conforme o disposto na Resolução CNS 196/96 e suas complementares. Os participantes receberam esclarecimentos quanto ao sigilo, ao anonimato $^{7}$, à privacidade e ao direito de desistência em qualquer momento da pesquisa, bem como sobre o destino do material obtido, registrado por meio áudio para fins científicos. Sua anuência formal foi firmada através da assinatura do Termo de Compromisso Livre e Esclarecido.

\subsection{Entrada em campo}

A pesquisa foi realizada nos meses de setembro e outubro de 2015 . O calor na cidade é muito forte, tanto que os moradores a chamam de "cidade do sol". Para chegar até a escola, no primeiro dia, peguei carona com uma das funcionárias com quem havia feito contato por $e$-mail e telefone. Nos dias seguintes, foi preciso recorrer ao serviço de moto taxi, pois não há transporte público para o bairro. Na primeira visita, pude acompanhar a entrada dos alunos observei e fui observada, com estranhamento, enquanto conversava com Maria, a vice-diretora da escola. Nesse dia, havia agendado entrevista com a diretora Manuela e aguardava sua chegada, mas, uma vez que o encontro foi adiado, aproveitei para conhecer o espaço e alguns professores e funcionários, de maneira a me colocar ali como pesquisadora.

Nos demais dias realizei entrevistas individuais com Manuela e com Maria, gestoras da escola, na sala de diretoria, a partir de roteiro semiestruturado (Apêndice C) a respeito dos seguintes pontos: o funcionamento da escola e sua relação com o reconhecimento da comunidade; as ações desenvolvidas para a efetivação das Diretrizes Curriculares para a Educação Escolar Quilombola; as organizações que apoiavam a escola na implementação da educação quilombola; a participação da comunidade na construção do projeto político pedagógico; e, a participação e visão dos atores escolares sobre as mudanças no tocante à forma

\footnotetext{
${ }^{7}$ Para preservar a identidade dos sujeitos participantes da pesquisa, os nomes adotados são fictícios, com exceção do professor Valter Luiz dos Santos Marcelo, que não é participante da pesquisa.
} 
como a educação proporcionada pela escola afeta a vida dos alunos e comunidades. A entrevista com Manuela me levou ao nome de Pedro, ex-integrante da Associação de Bairro e morador da comunidade que, segundo ela, poderia fornecer mais informações sobre o processo de reconhecimento da mesma.

No dia agendado para a entrevista de Pedro fiz uma longa caminhada de observação da comunidade, até chegar à sua casa. A entrevista com Pedro durou cerca de duas horas; nela busquei, principalmente, conhecer como se deu e quem participou do processo de reconhecimento da comunidade como quilombola, os desafios enfrentados e direitos adquiridos e a atuação da Associação de Moradores (que se formou a partir deste reconhecimento) na comunidade. A entrevista com Pedro nos levou a Carlos, um dos membros da Associação de Moradores, que foi entrevistado individualmente em sua residência. Esta entrevista foi orientada pelos mesmos objetivos de nossa conversa com Pedro.

Nos dias que se seguiram, retornei à escola para realizar entrevistas com professores e alunos. Foram realizadas entrevistas individuais com uma professora e um professor, na sala de informática da escola nas quais buscamos investigar como os professores viam as mudanças que estavam sendo empreendidas pela escola para implementação de uma educação quilombola: se os mesmos atuavam segundo as novas perspectivas; os meios que vinham servindo para sua preparação; e se viam mudanças nos alunos. Para tanto, utilizamos as seguintes questões norteadores: Como é trabalhar em uma escola quilombola?; Procura introduzir questões que dialogam com a proposta de educação das relações étnico-raciais, especialmente questões que envolvem quilombos, os saberes da comunidade quilombola?; O que mudou na escola depois que ela foi reconhecida como quilombola?

A entrevista, em grupo, com os alunos também ocorreu na sala de informática da escola. A princípio, a intenção era de realizar entrevistas individuais com alguns alunos e, em seguida, entrevista em grupo, através do grupo focal. No entanto, no dia da realização da primeira entrevista individual com um dos alunos, outros quiseram participar e o momento mostrou-se propício para a condução do grupo, pois além do grande interesse manifesto, estavam ali reunidas as condições que havia pensado como adequadas para a realização do grupo. $\mathrm{O}$ encontro foi configurado, conforme concepção de Bleger (1979), com flexibilidade suficiente para permitir que o campo se configurasse, o máximo possível, pelas variáveis que dependiam dos entrevistados.

Dessa forma, o encontro foi realizado a partir de um conjunto de questões que estavam orientando o meu olhar de pesquisadora, mas que não eram necessariamente colocadas ao 
grupo, pois no próprio desdobrar do encontro, nas trocas entre os participantes, elas eram abordadas. A primeira tarefa foi apresentar o tema que seria discutido. Durante o encontro, as intervenções eram feitas de acordo com o que estava sendo conversado no grupo, com o que surgia de mais significativo. O grupo permite a interação entre os sujeitos da pesquisa e o pesquisador, e entre eles próprios.

Dentre as questões que nortearam o encontro, citamos: O que é ser quilombola?; O que é ser negro?; O que sabem a respeito do reconhecimento da comunidade como remanescente de quilombo?; Como é estudar em uma escola quilombola?; O que mudou na escola após ser elevada à categoria de escola quilombola?; Quais atividades são desenvolvidas pela escola com relação à cultura e às histórias africana e afro-brasileira?

No encontro em grupo, assim como nas entrevistas individuais, exploramos o conhecimento que os participantes tinham a respeito do surgimento da comunidade. Em todos os momentos buscamos que o campo se configurasse a partir dos entrevistados, de maneira que pudessem expressar sua maneira de agir e pensar o tema pesquisado.

\subsection{Análise dos dados}

A interpretação e a análise dos dados foram realizadas com base na técnica de análise de conteúdo, proposta por Bardin (1995). O autor define análise de conteúdo como um conjunto de técnicas de comunicação, tendo como finalidade principal a interpretação dessas comunicações. Trivinôs (1987) identifica, como peculiaridades dessa técnica: a ênfase no conteúdo das mensagens para o desenvolvimento da análise; o fato das inferências do pesquisador serem realizadas a partir de uma apreciação objetiva do conteúdo das mensagens; e o fato do pesquisador possuir clareza das teorias que subsidiam o conteúdo das mensagens. $\mathrm{O}$ autor ressalta que a análise interpretativa dos dados deve estar baseada em três aspectos fundamentais: nos resultados alcançados no estudo; na fundamentação teórica; e na experiência pessoal do pesquisador.

Conforme as proposições de Bardin (1995), a organização da análise de conteúdo ocorreu nas seguintes três etapas:

A) Pré-análise: corresponde à seleção e organização do material coletado. No caso desta pesquisa, o material compreende as falas dos sujeitos, expressas por meio das entrevistas, além de dados do diário de campo. A sistematização foi realizada considerando-se objeto, objetivos e marco teórico conceitual. 
B) Descrição analítica: corresponde à etapa em que os dados são codificados. Nessa etapa, elencamos algumas categorias principais que emergiram a partir das falas dos sujeitos de pesquisa: memória, território, ancestralidade, corpo, ato político, religião. Estas categorias foram definidas a partir da consideração de que resumiam os sentidos de identidade percebidos nas falas dos participantes como mais significativos. Esta definição orientou parte das escolhas de leituras e noções que seriam discutidas, servindo de base para a organização da estrutura da tese.

C) Interpretação referencial: corresponde à etapa em que ocorre a interpretação dos dados. Nesta etapa, foram realizados o confronto e a articulação dos dados obtidos, o que permitiu criar uma síntese das ideias e representações dos sujeitos investigados. O conteúdo dos relatos foi analisado considerando as principais categorias e sentidos emergentes articulados, por sua vez, ao referencial teórico adotado em tópicos específicos. 


\section{CONTEXTUALIZANDO QUILOMBOS E O QUILOMBO URBANO DE BARRO PRETO}

\subsection{Quilombo e Comunidade remanescente de quilombo}

As construções e ressignificações em torno do termo quilombo, ao longo da história da sociedade brasileira, está vinculada a processos de luta política, construção de identidade, território e reflexões científicas. Tais processos, na atualidade, norteiam novos significados ao termo, recontextualizando-o. No entanto, a definição convencional de Quilombo como “[...] toda habitação de negros fugidos que passem de cinco, em parte desprovida, ainda que não tenham ranchos levantados nem se achem pilões neles"8 (MOURA, 1987, p. 16) ainda está ligada ao senso comum, criando dificuldades ao reconhecimento do direito das comunidades remanescentes de quilombo às suas terras.

Essa concepção genérica de quilombo foi utilizada pela legislação repressiva colonial para marginalizar e penalizar negros por sua resistência ao regime de violência da escravidão. Além disso, trata-se de uma visão deturpada, pois os quilombos no Brasil não se formaram exclusivamente a partir das fugas, mas também pela compra de terras por negros libertos, de terras entregues por antigos escravizados, de posse de terra abandonada pelos proprietários e da ocupação e administração das terras doadas por padroeiros (BRASIL, 1988).

Moura (1972, p. 11) define quilombo como “[...] a expressão mais radical de ruptura com o sistema brasileiro fundiário e escravista". Para o autor, o quilombo tem que ser visto como um elemento dinâmico, um instrumento de mobilização política e como forma de organização que atuou permanentemente no sistema nacional ${ }^{9}$. Nas palavras de Moura (1987, p. 12-13), a quilombagem no Brasil era fruto "[...] das contradições estruturais do sistema escravista e refletiam, na sua dinâmica, em nível de conflito social, a negação desse sistema por parte dos oprimidos". Sua definição confere ao quilombo um caráter de resistência ${ }^{10}$ e transformação social. Sendo assim, o quilombo deve ser entendido enquanto ferramenta

\footnotetext{
${ }^{8}$ Concepção de quilombo definida pelo Conselho Ultramarino, erigida no período colonial, no ano de 1740.

${ }^{9}$ Id., 2000.

${ }^{10}$ Segundo Moura (1981, p. 14), quilombagem não foi a única forma de resistência à escravidão, existiram outras “[...] como o assassínio dos senhores, dos feitores, dos capitães-do-mato, o suicídio, as fugas individuais, as guerrilhas e as insurreições urbanas se alastraram por todo o período. Mas o quilombo foi a unidade básica de resistência do escravo".
} 
analítica e conceitual, que não se restringe à escravidão, e como ferramenta sociocultural, cujo percurso histórico possibilita o entendimento da interação e inserção social da população negra.

As ressemantizações jurídicas em torno do termo revelam como o Estado se relaciona com este segmento social. Em 1988, temos a aprovação da Constituição Nacional que cria a designação "remanescentes de quilombos", expressa no artigo $68^{11}$ do Ato das Disposições Constitucionais Transitórias (ADCT): “Aos remanescentes das comunidades dos quilombos que estejam ocupando suas terras é reconhecida a propriedade definitiva, devendo o Estado emitir-lhes os respectivos títulos" (BRASIL, 1988).

Ao designar o termo "remanescentes de quilombos", o artigo cria sujeitos de direitos fundiários histórico-culturais, no entanto: quem são os remanescentes de quilombos? Como garantir estes direitos? Torna-se necessário, nesse contexto, definir a categoria "remanescente de quilombo", o que implica em uma revisão do termo quilombo para fins de aplicabilidade jurídica. Com este objetivo, o Ministério Público recorre à Associação Brasileira de Antropologia (ABA) e, em outubro de 1994 se forma o Grupo de trabalho sobre "Terras de Quilombos", sob a coordenação de Eliane Cantarino O’Dwyer. O mesmo elabora um documento trazendo novos significados para o termo "quilombo", numa perspectiva que o posiciona criticamente como um grupo dinâmico cuja existência está em consonância com sua capacidade de organização e relação com outros segmentos sociais.

Para Leite (2000), o documento expressa uma ressemantização do termo, que considera a variabilidade de experiências, na contrapartida da ideia estática de quilombo, que se refere ao termo como "resíduos arqueológicos de ocupação temporal ou de comprovação biológica" (O’DWYER, 2008, p. 02). Para a autora, o documento busca desfazer os vários equívocos referentes à suposta condição de "remanescente" a fim de resolver os impasses conceituais ocasionados pelo uso do termo na Constituição de 1988. Leite (2000, p. 341) observa que a categoria "remanescente" tornou-se restrita "[...] ao remeter à ideia de cultura como algo fixo, algo cristalizado, fossilizado, e em fase de desaparecimento".

Segundo Arruti (2006), o uso do termo "remanescente", pelos legisladores, foi intencional e faz parte de um arcabouço histórico de classificação de populações negras e indígenas, tendo como intuito a homogeneização e exclusão social desses grupos. O autor assinala que o termo já havia sido empregado para tratar da situação de populações indígenas

\footnotetext{
${ }^{11}$ Esta lei discute e reconhece o direito dos quilombolas a seus territórios e a obrigação do Estado em legalizar a posse, lhes emitindo os títulos de propriedade da terra. Somando-se ao artigo 68 temos os artigos 215 e 216 , os quais se dedicam sobretudo à proteção das manifestações culturais negras.
} 
do Nordeste que reivindicavam seus direitos, mas que não possuíam sinais externos que pudessem comprovar seu pertencimento, o que, por conseguinte, causava dificuldades ao seu reconhecimento jurídico enquanto tal. Neste caso, o uso do termo "remanescente" solucionou esse problema ao "[...] relativizar o exótico, o isolamento e a continuidade de uma carga cultural homogênea e autônoma" (ARRUTI, 2006, p. 81) e para representar os grupos quilombolas como restos, sobras e reminiscências do passado.

Segundo Gusmão (1996), a designação "remanescente de quilombo" parece indicar que a noção antiga de quilombo está presente no âmbito jurídico, pois este, em suas primeiras iniciativas de implementação do artigo 68, impunha como obrigatória a comprovação de uma ascendência africana através de resquícios arqueológicos ou biológicos. Esta definição restritiva cria ambiguidades à interpretação deste dispositivo legal pois, ao mesmo tempo em que reconhece os sujeitos de direito "remanescentes de quilombos", põe em risco este direito quando não reconhece a forma diversa com que se constituíram no Brasil, desconsiderando o processo identitário como algo contínuo e dinâmico.

Para Almeida (1996, p. 12), é necessária uma ressemantização do termo quilombo que coloque em dúvida a definição “jurídico-formal historicamente cristalizado", baseada em uma visão arqueológica e histórica de quilombo, à qual denomina de frigorificada. Para o autor, esta visão funciona como uma "camisa-de força" que considera quilombo como um lócus petrificado:

[...] o quilombo já surge como sobrevivência, como 'remanescente'. Reconhece-se o que sobrou, o que é visto como residual, aquilo que restou, ou seja, aceita-se o que já foi. Julgo que, ao contrário, se deveria trabalhar com o conceito de quilombo considerando o que ele é no presente. Em outras palavras, tem que haver um deslocamento. Não é discutir o que foi, e sim discutir o que é e como essa autonomia foi sendo construída historicamente. Aqui haveria um corte nos instrumentos conceituais necessários para se pensar a questão do quilombo, porquanto não se pode continuar a trabalhar com uma categoria histórica acrítica nem com a definição de 1740 (ALMEIDA, 2002, p. 53-54).

Deve-se considerar, portanto, a atualidade dos quilombos, que aparece desvinculada de seu campo de significação "original" de matriz colonial para que se redefina o que está frigorificado no senso comum: o termo "remanescente", nesse sentido, remete a reminiscências, algo que não representa os grupos cuja identidade étnica se fundamenta no que é vivido. Desta forma, podemos compreender que a reconceituação do termo corresponde a uma afirmação étnica e política dos sujeitos contemplados pelo artigo 68, sendo que estes, ao se autorreconhecerem e se autodefinirem como quilombolas ocasionam, em nível constitucional, "redefinições de seus instrumentos interpretativos", na medida em que proporcionam uma 
inversão simbólica em que "remanescente de quilombo" não exprime "sobras" do passado ou marginalidade e criminalidade, mas especificidades a serem reconhecidas (ALMEIDA, 1996).

A aprovação do referido artigo é fruto de um cenário político efervescente dos anos de 1970 a 1980, em que novos grupos sociais foram surgindo e se organizando, entre eles o Movimento Negro Brasileiro (MNU). Especificamente nos anos 1980, no contexto da "redemocratização", diversos movimentos sociais, até então subrepresentados, avançam com suas reinvindicações, entre eles os movimentos camponês, indígena e de categorias de trabalhadores (ARRUTI, 2000).

Segundo este autor, devido à pressão destas mobilizações, o Ministério da Reforma Agrária e os órgãos fundiários são obrigados a reconhecer a existência de ocupações fundiárias excluídas das categorias censitárias e cadastrais utilizadas pelos órgãos governamentais. "Entre essas ‘ocupações especiais' estavam aquelas entregues a, ou adquiridas por famílias de exescravos, ou antigos escravos organizados em quilombos, com ou sem diplomação legal" (ARRUTI, 2000, p. 104 apud ALMEIDA, 2002).

Em 1986 temos os primeiros encontros de representantes do movimento das comunidades negras rurais: no Maranhão é organizado o I Encontro de comunidades Negras Rurais e, no Pará, o I Encontro de Raízes Negras. Entre os anos 1980 e 1990 foram constantes as mobilizações populares em torno da regulamentação e efetivação do artigo 68; em 1988 ocorrem dois grandes acontecimentos políticos: o centenário da abolição e a Assembleia Constituinte, “[...] o primeiro de reavaliação e balanço sobre o passado; o segundo de projeção para o futuro - um retroalimentando o outro, e ambos produzindo uma mudança profunda na situação política dos negros brasileiros" (LEITE, 2008, p. 975).

É importante destacar que a ressignificação do termo, assim como o ingresso da categoria "remanescente das comunidades quilombolas" na constituinte de 1988 (ano em que se comemora o centenário da abolição da escravatura) foram decorrentes destes movimentos organizados pela própria população negra e quilombola, cujos agentes se apropriaram dos instrumentos jurídicos e se mobilizaram para a efetivação dos seus direitos (LEITE, 2000). Nesse contexto, parlamentares envolvidos na luta antirracista, entre eles Abdias do Nascimento $^{12}$, juntamente com militantes do Movimento Negro Unificado ${ }^{13}$, reivindicam

\footnotetext{
${ }^{12}$ Abdias do Nascimento fez parte da militância política negra sendo um dos fundadores da Frente Negra Brasileira nos anos 30 e do Teatro Experimental do Negro - TEM em 1944.

${ }^{13}$ O Movimento Negro Unificado foi criado em 1978, sendo importante para a unificação de demandas e iniciativas em torno da luta política contra a violência racial e a favor da ampliação dos direitos do povo negro. Este movimento trouxe novas pautas para discussões com um forte conteúdo de afirmação da identidade negra e reinvindicação da negritude.
} 
reparação à opressão histórica sofrida pelo povo negro diante da Assembleia Constituinte (LEITE, 2008).

Nascimento (1980) reescreve suas teses sobre "Quilombismo"14, procurando aperfeiçoá-las para fundamentar as discussões em torno de medidas necessárias à regulamentação do artigo 68. Nesse sentido, a ressemantização do termo "quilombo" pelos próprios movimentos sociais são:

[...] os princípios de liberdade e cidadania negados aos afrodescendentes, correspondendo, a cada um deles, os respectivos dispositivos legais: 1 - Quilombo como direito a terra, como suporte de residência e sustentabilidade há muito almejadas nas diversas unidades de agregação das famílias e dos núcleos populacionais compostos majoritariamente, mas não exclusivamente de afrodescendentes. [...] 2Quilombo como um conjunto de ações em políticas públicas e ampliação de cidadania, entendidas em suas várias dimensões. 3- Quilombo como um conjunto de ações de proteção às manifestações culturais específicas (LEITE, 2008, p. 970).

Segundo Arruti (2000), Abdias do Nascimento pode ser considerado um dos percursores dos processos de ressemantização e ressignificação do termo quilombo pois, ao criar a categoria simbólica ${ }^{15}$ "quilombismo", rompe com a visão tradicional, sugerindo as expressões: reunião fraterna e livre; solidariedade; convivência; comunhão existencial (NASCIMENTO, 1980). No entanto, a perspectiva frigorificada figurou entre integrantes do Movimento Negro até meados dos anos de 1990, a exemplo da definição da Fundação Cultural Palmares (FCP), em 1990 ${ }^{16}$, apresentada por Arruti (2006, p. 83): “[...] quilombos são os sítios historicamente ocupados por negros que tenham resíduos arqueológicos de sua presença, inclusive as áreas ocupadas ainda hoje por seus descendentes, com conteúdo etnográficos e culturais" 17 .

Em 1994, durante o seminário intitulado "Conceitos de Quilombos", nota-se uma modificação apresentada pela FCP: comunidades negras rurais são definidas como agrupamentos de descendentes de negros escravizados que retificam o vínculo com o passado

\footnotetext{
${ }^{14}$ Quilombismo é definido pelo autor como Movimento político dos negros brasileiros, um projeto político que visa a construção de um "Estado Nacional Quilombista", cuja finalidade não está na segregação, mas na constituição de uma sociedade democrática, em que os negros estivessem representados em todos os níveis de poder.

${ }^{15}$ Segundo Arruti (2000, p. 105), quilombo surge, no meio acadêmico, como metáfora de resistência, no ano de 1944, no Livro de Edson Carneiro, "O Quilombo de Palmares" (publicado apenas em 1947). No entanto, através de Abdias do Nascimento, quilombo se consolida como símbolo de resistência no cenário público ainda nos anos 1940. Nos anos 1970, a ideia de Quilombo como ícone de resistência negra aparece incorporada de maneira definitiva nos escritos de acadêmicos, como Clóvis Moura e outros, assim como no interior do Movimento Negro.

${ }^{16}$ Nos anos de 1990, foram empreendidas as primeiras iniciativas pela Fundação Cultural Palmares para aplicação do artigo constitucional, tendo em vista as demandas dos grupos a serem contemplados pela sua efetivação.
}

${ }^{17}$ Revista ISTOÉ, 20/06/90, p. 34 apud ARRUTI, 2006, p. 83. 
através da prática da cultura de subsistência e de manifestações culturais, com a finalidade de manter sua identidade (MOURA, 1994). Segundo o autor, trata-se de uma visão utilitária da identidade, cujo intuito é de dar um sentido de continuidade, verificada não pela presença de resquícios do passado, mas por "traços culturais" que "exaltam a etnicidade". Observa-se que esta definição, mesmo que pragmática, apresenta identidade em termos étnicos.

A referência à etnicidade também esteve presente no documento enviado pela Associação Brasileira de Antropologia (ABA) ao Primeiro Seminário Nacional das Comunidades Remanescentes de Quilombos, promovido pela Fundação Cultural Palmares, realizado em Brasília, no mesmo ano. Neste texto, a ressemantização baseia-se em novas categorias como: grupos étnicos, autoatribuição e uso comum. A abordagem conceitual tinha como intuito abarcar a pluralidade histórica dos grupos quilombolas e desenvolver instrumentos analíticos que pudessem justificar, perante os campos jurídico e administrativo, o direito à posse e título de terras, tendo em vista a consolidação dos direitos previstos no artigo 68. Nesse sentido, a proposta da $\mathrm{ABA}$ busca uma ressemantização contemporânea sobre quilombos, considerando suas novas formas significativas que, na atualidade, se expressam na luta dos movimentos sociais pela garantia da terra e reconhecimento de sua identidade (ALMEIDA, 1996).

Desse modo, compreende-se "remanescente de quilombos" como grupos organizados politicamente, cuja identidade “[...] não se define pelo tamanho e número de seus membros, mas pela experiência vivida e as versões compartilhadas de sua trajetória comum e da continuidade enquanto grupo" (O’DWYER, 2008, p. 10). Estes grupos são definidos como étnicos "[...] um tipo organizacional que confere pertencimento através de normas e meios empregados para indicar afiliação ou exclusão" (BARTH, 1969 apud O'DWYER, 2008, p. 12). Portanto, de acordo com esta perspectiva teórica, a constituição desses grupos se estabelece de modo contrativo na interação social com outros grupos, em que se identificam ou são identificados mediante as relações estabelecidas e a participação de seus membros.

Segundo Arruti (2006, p. 93) “[...] o conceito de grupo étnico impõe uma definição de remanescentes de quilombos calcada em critérios subjetivos e contextuais, marcados pela ideia de contrastividade ${ }^{18}$, por meio da qual um grupo se percebe e se define sempre pela oposição (no caso, o conflito fundiário) a um grupo". Analisando esta concepção, pode-se perceber que a formação de um grupo étnico ocorre quando o grupo passa a se definir de acordo com suas

\footnotetext{
${ }^{18}$ Neste caso, como assinala O’Dwyer (2009), a contrastividade cultural não é mais realizada pelo observador externo (o pesquisador), mas pelos próprios atores sociais, os quais selecionam as diferenças que consideram mais significativas.
} 
próprias características subjetivas, em um processo identitário que emerge diante de situações de conflito, ou seja, contrapondo-se às “[...] autoevidências intrínsecas à ideologia escravocrata e os preceitos jurídicos dela emanados" (ALMEIDA, 1996, p. 15). Trata-se de uma identidade coletivamente construída, cuja afirmação está balizada em critérios organizacionais (interesses e reinvindicações comuns) e cujo percurso se estabelece mediante atitude positiva de conversões política e simbólica de valores e estigmas sociais.

Embora reconheça a importância da categoria "grupos étnicos" pelos antropólogos como instrumento analítico, Arruti (2006) adverte sobre sua utilização sem que se considere a realidade dos grupos pesquisados, o que inviabilizaria conexões entre o grupo descrito como étnico e a categoria jurídica "remanescente de quilombo", uma vez que o campo jurídico faz do grupo étnico instrumento para fixar normas e critérios de identificação.

Esta problemática pode ser observada através da fixação da autoatribuição "remanescente de quilombo" como norma de identificação. O mesmo atou alerta, ainda, para o fato de que há casos em que a autoatribuição, nesta perspectiva, pode não existir. Nestes casos, deve haver um trabalho de ressemantização das formas de identificação (autoatribuições nativas) indiretamente relacionadas ao quilombo, para que se possa corrigir, tanto o percurso da simbologia nativa quanto da simbologia do artigo 68 , encontrando um ponto de convergência entre ambas.

Por outro lado, ao realizar um trabalho de identificação, utilizando-se da categoria de "grupos étnicos” com base em autoatribuições nativas, os pesquisadores consideram a noção contemporânea de quilombo como organizações sociais mobilizadas politicamente em torno da defesa de suas terras. Esta definição permite a operacionalização do termo "remanescente de quilombos", pois dialoga com o processo de emergência étnica em curso sem que seja, necessariamente, imperativo relacioná-lo com a noção histórica convencional. Além disso, rompe-se com a idealização e a simbolização de quilombo como “[...] "pequenas áfricas”, que poderia remeter a uma ideia de resistência cuja contrapartida seria a conservação e/ou o retorno ao passado" (ARRUTI, 1997, p. 26)

Assim, na atualidade, os remanescentes de quilombos, em suas especificidades, podem apresentar ou não "fatores primordiais": "origem ou ancestrais em comum; hábitos ou religiosidade compartilhados; vínculo territorial centenário; parentesco social generalizado; homogeneidade racial, entre outros" (ARRUTI, 2006). Nota-se que não se trata de abandonar o sentido histórico de quilombo, com relação ao reconhecimento de grupos que tiveram, de fato, sua origem, mas ampliar este sentido de forma a contemplar a diversidade das 
“comunidades negras rurais", considerando suas especificidades e modalidades distintas de uso comum da terra.

Arruti (2006, p. 90) alerta que "[...] no lugar de fuga e isolamento a ressemantização lança mão do paradigma do uso comum”; portanto, “[...] no que diz respeito à territorialidade desses grupos, a ocupação da terra não é feita em termos de lotes individuais, predominando seu uso comum ${ }^{19 "}$ (O’DWYER, 2008, p. 10). O termo "uso comum" surge a partir do estudo de Alfredo Wagner Berno de Almeida (1989), realizado na Comunidade de Frechal, no Maranhão, em $1988^{20}$, como elemento importante no processo de ressemantização. O autor caracteriza terras de uso comum como

\begin{abstract}
Situações nas quais o controle dos recursos básicos não é exercício livre e individualmente por um determinado grupo doméstico de pequenos produtores diretos ou por um dos seus membros. Tal controle se dá através de normas especificas instituídas para além do código legal vigente e acatadas, de maneira consensual, pelos vários grupos familiares que compõe uma unidade social. (ALMEIDA, 1989, p. 163)
\end{abstract}

A territorialidade relacionada ao uso comum permite contemplar domínios quilombolas de origens diversas, com denominações específicas relativas a diferentes modalidades de uso comum: Terras de Preto; Terras de Santo; Terras de Irmandade; Terras de Índio; Terras de Herança. Estes nomes advêm da autodenominação e autorepresentação de grupos que se formaram durante o sistema escravocrata e que assim se denominaram com intuito de se livrar dos estigmas de criminalidade, desordem, cultura marginal e periférica, pois "[...] admitir que era quilombola equivalia ao risco de ser posto à margem" (ALMEIDA, 1996, p. 17). O autor ressalta que este estigma é positivado quando da sua reinvindicação pública, uma vez que, ao assumirem-se quilombolas, estes grupos criam possibilidades para a sua institucionalização legal, ou seja, sua autodefinição é ponto de partida para a redefinição do significado do quilombo dentro do pensamento jurídico.

Nesse sentido, Arruti (2006, p. 86) afirma que “[...] o rótulo quilombo hoje está ligado a uma mobilização política para negar o estigma e reivindicar cidadania”. Esses grupos rompem com o silêncio emergindo como sujeitos políticos coletivos no século XX, com a aprovação do artigo constitucional, ao assumirem o "rotulo jurídico" "remanescente de quilombo". Esta categoria surge pelo mesmo ato que a instituiu como sujeito de direito: “[...] a criação do nome

\footnotetext{
19 O termo "uso comum" traz à tona referência a uma origem baseada no campesinato constituído por negros libertos e seus descendentes, no contexto da desagregação e da escravidão e de sua abolição (LEITE, 2006, p. 105)

${ }^{20} \mathrm{O}$ estudo foi uma das primeiras pesquisas realizadas em Comunidades Negras Rurais. Tornou-se muito importante na discussão acerca do reconhecimento dos grupos remanescentes de quilombos e do papel dos laudos antropológicos neste processo.
} 
está ligada ao surgimento da coisa" (ARRUTI, 2006, p. 23), onde "coisa” é a figura jurídica "remanescente de quilombo", o que não quer dizer que os sujeitos assim designados não existissem antes do surgimento do termo.

Trata-se, ainda segundo o autor, de uma identidade étnica construída e reivindicada coletivamente, que faz referência a uma realidade comprovável, ao mesmo tempo em que é produção dessa mesma realidade. Dessa forma, compreende-se esses grupos como emergentes, considerando que as condições de acesso aos novos direitos e de exercício de sua identidade não se apresentam completamente definidas, mas são delineadas por estes sujeitos e por seus concorrentes a mediadores - antropólogos, historiadores, Estado e seus ordenamentos jurídicos.

A ressemantização do termo percorreu um longo caminho, vários discursos foram produzidos entre juristas, antropólogos, representantes do legislativo e grupos quilombolas, entre outros. Nessa trajetória, o reconhecimento legal das "comunidades remanescentes de quilombo" esteve fundamentado em duas problemáticas principais: qual seria o órgão responsável por realizar a demanda desses grupos; e como seriam definidos os critérios de identificação. Visando a resolução dessas problemáticas, foram formulados decretos, leis, artigos e medidas provisórias. Em especial, em 2003, temos a promulgação do Decreto $\mathrm{n}^{\circ}$ $4.887^{21}$ que, entre outros dispositivos, atualmente “[...] regulamenta o procedimento para identificação, reconhecimento, delimitação, demarcação e titulação das terras ocupadas por comunidades remanescentes de quilombos, de que trata o Art.68 do ADCT" 22 (O’DWYER, 2009 , p. 173) ${ }^{23}$.

\footnotetext{
${ }^{21}$ Esse decreto foi antecedido pelo Decreto $\mathrm{n}^{\circ} 3.912$, publicado em 2001, que deu abertura à identificação, ao reconhecimento e à titulação das comunidades remanescentes de quilombos. No entanto, esse decreto trazia em seu artigo $1^{\circ}$ uma visão frigorificada de quilombo, ao colocar que "[...] somente pode ser reconhecida a propriedade sobre terras que: I - eram ocupadas por quilombos em 1888; II - estavam ocupadas por remanescentes das comunidades dos quilombos em 5 de outubro de 1988".
}

${ }^{22}$ Entre os dispositivos jurídicos que regulamentam o Artigo 68 do ADCT, encontram-se: a Convenção 169 da OIT, sobre Povos Indígenas e Tribais, ratificada pelo governo brasileiro (Portaria $\mathrm{n}^{\circ} 6$, de $1^{\circ}$ de março de 2004, do Ministério da Cultura/Fundação Cultural Palmares); o Decreto n ${ }^{\circ}$ 5.051, de 19 de abril de 2004; na Instrução Normativa $\mathrm{n}^{\circ}$ 20, de 19 de setembro de 2005, do Instituto Nacional de Colonização e Reforma Agrária (INCRA)/Ministério de Desenvolvimento Agrário (MDA); o Decreto no 6.040, de 7 de fevereiro de 2007, que institui a Política Nacional de Desenvolvimento Sustentável dos Povos e Comunidades Tradicionais (PNPCT).

${ }^{23}$ De acordo com o Decreto $n^{\circ} 4887 / 2003$, a Fundação Cultural Palmares é responsável por incluir e emitir certificado de inclusão no Cadastro Geral de Remanescentes das Comunidades de Quilombos daquelas comunidades que assim se designam. Após a emissão dessa certidão, a comunidade poderá requerer o seu reconhecimento junto ao INCRA, que deverá regulamentar os procedimentos administrativos para identificação, reconhecimento, delimitação, demarcação e titulação das terras ocupadas pelos remanescentes. O processo de regulamentação fundiária envolve algumas etapas: Incra realiza um estudo da área para a elaboração de um Relatório Técnico de Identificação e Delimitação (RTID) do território. Após a publicação desse relatório, abre-se a oportunidade para sua contestação. Em seguida publica-se, no Diário Oficial, o relatório definitivo. Daí tem-se a etapa de "desintrusão" - desapropriação de não quilombolas e/ou pagamento de indenização e demarcação. O processo é concluído com a concessão do título de propriedade à comunidade (coletivo, inalienável, imprescritível, 
Efetivamente, o Decreto $\mathrm{n}^{\mathrm{o}} 4887 / 2003$ determina, em seu artigo $2^{\circ}$, o direito ao autorreconhecimento e à existência dos quilombolas enquanto "[...] grupos-étnicos, segundo critérios de autoatribuição, com trajetória histórica própria, dotados de relações territoriais específicas, com presunção de ancestralidade negra relacionada com a resistência à opressão histórica sofrida" (BRASIL, 2003).

O’Dwyer (2009, p. 173) relata que o mesmo não previa a participação de antropólogos no processo de identificação, ou seja, mediante o critério de autorreconhecimento, os relatórios antropológicos não seriam mais necessários para "atestar" a identidade quilombola dos grupos que reivindicam a aplicação do artigo 68. Desta maneira, a Associação Brasileira de Antropologia (ABA), em audiência pública, defendendo sua participação no processo de reconhecimento das comunidades negras remanescentes de quilombos:

[...] defendeu que a auto-definição utilizada pelos próprios atores sociais não prescinde da realização de estudos técnicos especializados que venham a descrever e interpretar a formação de identidades étnicas no bojo do processo de reconhecimento das comunidades negras remanescentes de quilombos, na medida em que esses estudos tragam subsídios para uma decisão governamental e forneçam elementos para que o próprio grupo possa se defender de possíveis formas de intervenção estatal que possibilite apenas a reprodução das categorias sociais, sem garantir as condições para a perpetuação de padrões culturais, modos de vida e territorialidades especificas.

Segundo O’ Dwyer (2009), devido a uma ação movida pela PFL (Frente Liberal), pelo MDA (Ministério de Desenvolvimento Agrário) e pelo INCRA, é formulada uma nova Instrução Normativa n. 20 ((19/09/2005), que determina a necessidade de laudos antropológicos na elaboração de estudos e relatórios nos processos de reconhecimento. A autora sinaliza preocupação com relação ao trabalho dos antropólogos, na medida em que a administração pública tende a estabelecer manuais com normas e regras a fim de apreender ou delimitar objetivamente uma realidade que, por sua dinamicidade, não pode ser apreendida: corre-se o

impenhorável) em nome da associação dos moradores da área, que tem de ser registrado no cartório de imóveis. (Cf. Instituto Nacional de Colonização e Reforma Agrária - Disponível em: < http://www.incra.gov.br/estruturafundiaria/quilombolas> Acesso em: 01 nov 2017). Em 2016, com o governo Temer, houve muitos retrocessos com relação à política de regulamentação de terras quilombolas. Por meio do Decreto $\mathrm{n}^{\circ}$ 8.780/2016, a competência para titulação dessas comunidades foi transferida para a Casa Civil, passando o Incra a ficar subordinado ao ministério mais próximo à presidência da república. (Cf. Comissão Pró-Índio de São Paulo. Terras Quilombolas: Indefinições na política de regularização das terras quilombolas. Disponível em: <http://comissaoproindio.blogspot.com.br/2016/06/terras-quilombolas-maio-indefinicoes-na.html>. Acesso em 01 nov 2017). Segundo o Incra, existem hoje 1692 processos de regularização fundiária de territórios quilombolas. Destes, apenas 454 tiveram algum avanço burocrático. São 219 títulos expedidos para 151 comunidades, totalizando 752 mil hectares e cerca de 15,6 mil famílias beneficiadas. (Cf. Justificando - mentes inquietas pensam direito. Noticia: STF julga amanhã ação do DEM contra quilombolas. Disponível em: http://justificando.cartacapital.com.br/2017/08/15/stf-julga-amanha-acao-do-dem-contra-quilombolas/ Acesso em: 02 nov. 2017). 
risco de “[...] não gerenciar as diferenças, mas de eliminá-las por uma uniformidade jurídica que se sobrepõe a outros saberes e tradições” (O’ DWYER, 2009, p. 177).

A mesma autora refere, ainda, que, na Instrução Normativa $n^{\circ} 20$, referente às orientações sobre os procedimentos de identificação, pode-se observar uma imposição de que a eficácia desse instrumento seja alcançada através da rigorosidade. Entretanto, estas reflexões levam ao entendimento de que o rigor exigido por normas jurídicas contraria a experiência cotidiana e situações sociais estudadas pelas ciências humanas, pois elas são, em sua essência, dinâmicas e formalizadas, muitas vezes, de modo subjetivo.

A ressignificação do termo quilombo e a adoção do autorreconhecimento ${ }^{24}$ são bases fundamentais para a contestação e superação de visões deturpadas, presentes no imaginário social brasileiro, com relação à diversidade das comunidades referidas. O quilombo, hoje reivindicado como direito, traduz não apenas a luta de negros especificamente quilombolas, mas de toda a população negra brasileira. A reatualização de seus significados ocorre a partir das metamorfoses sociais, em um processo em que ele próprio engendra transformações sociais. Esse processo pode ser compreendido como forma de reação à dominação institucionalizada, conferindo ao quilombo um caráter atemporal, que foge às amarras de marcos cronológicos ou espaciais.

\footnotetext{
${ }^{24}$ Em 2004, o Partido Democratas (DEM) entrou com Ação Direta de Inconstitucionalidade (ADI 3239) contra o Decreto $\mathrm{n}^{\circ} 4.887 / 2003$, questionando o critério de autoatribuição e argumentando que, de acordo com o ADCT, a data marco de reconhecimento dos locais de ocupação deve ser dia 5 de outubro de 1988. Algumas entidades e grupos de grandes proprietários de terra se manifestam a favor do ADI 3239, afim de resguardar seus interesses. Em abril de 2012, o então ministro Cezar Peluso, presidente do STF, julgou procedente a ação do DEM. A tese defendida pelo DEM e a bancada ruralista baseia-se na visão frigorificada de quilombo, pregando que a autoidentificação levaria ao reconhecimento de comunidades que não tem relação com os habitantes de comunidades formadas por escravos fugidos. Em março de 2015, a ministra Rosa Weber rejeitou o questionamento do DEM, reconhecendo o critério de autoatribuição. Ela ressaltou que "[...] a eleição do critério de autoatribuição não é arbitrária, tampouco desfundamentada ou viciada. Além de consistir em método autorizado pela antropologia contemporânea, estampa uma opção de política pública legitimada pela Carta da República, na medida em que visa a interrupção do processo de negação sistemática da própria identidade aos grupos marginalizados". Acrescentando ainda que "[...] mostra-se necessária a satisfação de um elemento objetivo: a reprodução da unidade social que se afirmar originada de um quilombo há de estar atrelada a uma ocupação continuada do espaço ainda existente, em sua organicidade, em 5 de outubro de 1988". (Cf. Site Supremo Tribunal Federal. Disponível em: http://www.stf.jus.br/portal/cms/verNoticiaDetalhe.asp?idConteudo=288144\&tip=UN. Acesso em: $17 \mathrm{de}$ fev de 2017). Ainda que tenha votado pela constitucionalidade do Decreto $\mathrm{n}^{\circ} 4.887 / 2003$, a ministra endossou o "marco temporal". Este marco é extremamente prejudicial às comunidades quilombolas e indígenas, uma vez que desconsidera a forma injusta com que se deu a formação do território nacional e as inúmeras pressões sofridas que impuseram a algumas comunidades a necessidade de deixarem seu território original. Em agosto de 2017, o processo voltou à pauta do Supremo Tribunal Federal, mas foi adiado. $\mathrm{O}$ caso tramita em julgado e até a presente data (02 nov. 2017) não houve nova votação. Esse contexto tem atravancando o processo de titulação de várias comunidades quilombolas. Caso venha a ser aprovada, a ADI 3239 será um dos maiores retrocessos dos direitos quilombolas no Brasil. (Cf. Justificando - mentes inquietas pensam direito. Noticia: STF julga amanhã ação do DEM contra quilombolas. Disponível em: http://justificando.cartacapital.com.br/2017/08/15/stf-julga-amanhaacao-do-dem-contra-quilombolas/. Acesso em: 02 nov. 2017).
} 
O quilombo como direito se afirma, portanto, como “[...] uma espécie de potência que atravessa hoje a sociedade e o Estado - embaralhando as identidades fixas e a configuração de parentesco, do local, do regional, nacional", na medida em que integra diversas noções de direito sociais que para se efetivarem necessitam da desnaturalização dos direitos anteriores de propriedade, dos saberes supostos sobre a história (LEITE, 2008, p. 975). Nesse sentido, questiona-se a viabilidade da justiça em uma nação marcada por classificações hierárquicas, baseadas na valorização da identidade étnico-racial branca, na naturalização de estigmas e preconceitos e, por conseguinte, na exclusão social da população negra. Assim, o quilombo se apresenta como elemento insurgente, cujo processo identitário está em permanente construção.

\subsection{Quilombos urbanos e territórios negros}

Os quilombos no Brasil se constituíram das mais variadas formas, mas guardam a especificidade da necessidade das pessoas de se fixarem em determinado território, tendo em vista sua sobrevivência em meio à desigualdade e à violência raciais. Essa fixação não se limitou a territórios distantes ${ }^{25}$ para abrigo em caso de fuga, deu-se como modo de sobrevivência em locais próximos a grandes centros urbanos onde surgiram os primeiros quilombos urbanos, constituídos por:

[...] casas de pau-a-pique, construídas com barro e pequenos troncos de árvores. Plantados em clareiras na mata, os casebres eram rodeados pelas criações de cabras, galinhas, porcos e animais de estimação. Com o tempo, os quilombolas fizeram pequenas roças de milho e mandioca, sem dúvida, um traço da influência indígena. (ROCHA; LIMA, 2011).

Essas formações têm origem ainda no período colonial e, segundo Silva (2003), surgiram a partir da formação de pequenos povoados constituídos por negros libertos e fugitivos que buscavam refúgio e sobrevivência perto dos mercados e portos de cidades. A proliferação dos quilombos urbanos ocorreu, sobretudo, nas cidades portuárias, como Rio de Janeiro e Salvador, principalmente a partir de 1808, quando da chegada da família real portuguesa ao Brasil, e trouxe dinamismo à economia dessas localidades. Nesses centros urbanos, negros

\footnotetext{
${ }^{25}$ Quilombos localizados em regiões distantes das cidades e estradas, conhecidos como quilombos históricos como, exemplo: Palmares (Pernambuco); Cabula (Salvador); e Ambrósio (Minas Gerais).
} 
fugidos procuravam se misturar à massa urbana constituída por homens livres, escravos domésticos, escravos de ganho ${ }^{26}$, entre outros segmentos sociais.

A existência do escravo de ganho é uma evidência de que a escravidão não se restringiu ao espaço rural. Santos (2006) assinala que o sistema escravista tinha a escravidão urbana como parte de sua composição, evidenciando sua eficácia ao se entranhar no cotidiano da cidade, perpassando suas leis e práticas. Segundo a autora, a população cativa urbana, composta por escravos domésticos, habitava principalmente cômodos localizados nos porões, quartinhos e edículas das casas dos senhores; enquanto que os escravos de ganho, geralmente, moravam em "malocas", casas de cômodos e cortiços, construídas por eles ou alugados, em locais deteriorados do centro ou nos menos valorizados da periferia da cidade.

As atividades diárias realizadas por esses trabalhadores em situação de escravidão urbana exigiam deslocamentos constantes pelos diversos espaços da cidade; isso dificultava a identificação e captura de negros fugidos por parte das autoridades policiais. Segundo Gomes (2015, p. 09) “[...] nas cidades, os obstáculos eram grandes. Com tantos africanos e crioulos, entre becos e vielas - carregadores de carga, quitandeiras e outros tantos trabalhadores urbanos -, não era fácil identificar um fugido. Eram, ao mesmo tempo presentes e invisíveis.” Havia uma "mistura de lugares sociais" dificultando a distinção entre escravos, libertos e pretos livres, o que possibilitava uma certa camuflagem da condição social de escravo (CHALHOUB, 1988). Assim, foi possível se constituírem, no meio urbano, espaços de resistência de difícil controle social. $^{27}$

A presença dos negros fugidos nas cidades ou em situação de escravidão facilitava a mobilização desses segmentos nas ruas, o que era visto com grande temor pelas autoridades da colônia, depois do Império, que temiam a eclosão de revoltas escravas. Dessa forma, assim como aqueles localizados no interior do país (os chamados quilombos de rompimento), os quilombos urbanos sofriam com perseguições e, com o passar do tempo, também se tornaram centrais na resistência à escravidão. Alguns foram denominados de quilombos abolicionistas ${ }^{28}$, por abrigarem libertos das fazendas; várias fugas em massa foram incentivadas por ações e

\footnotetext{
${ }^{26}$ Escravo "de ganho" ou "ao ganho" é termo utilizado para se referir especificamente a negros em situação de escravidão que vendiam seus serviços nos centros urbanos, mas que tinham que entregar uma quantia estipulada previamente para seu proprietário (SANTOS, 2006).

${ }^{27}$ Id., 1990.

${ }^{28}$ Silva (2003) cita como exemplo de quilombos abolicionistas no Rio de Janeiro, os quilombos de Petrópolis, do Leblon e do Jabaquara.
} 
entidades abolicionistas como a Confederação Abolicionista, localizada no Rio de Janeiro, e os Caifazes, da cidade de São Paulo (SILVA, 2003). Caracteriza-se, assim, o quilombo abolicionista como um novo modelo de resistência à escravidão em relação aos quilombos de rompimento, representativos do modelo tradicional de resistência.

Ainda segundo o autor, no quilombo abolicionista, o contato com a sociedade envolvente era essencial e fazia parte do jogo político - suas lideranças eram homens conhecidos que intermediavam as relações entre o quilombo e a sociedade, enquanto que no quilombo de rompimento a estratégia era manter em segredo a organização interna e as lideranças, afastando-se o máximo possível da sociedade civil. Entretanto, esse afastamento não caracterizava um isolamento da sociedade, uma vez que as relações estabelecidas com o exterior eram essenciais para sua manutenção ${ }^{29}$; conforme Reis (1996, p. 332), o isolamento dos quilombos é um mito construído na historiografia oficial brasileira, na qual predomina:

\begin{abstract}
[...] uma visão do quilombo que o coloca isolado no alto da serra, formado por centenas de escravos fugidos que se uniam para reconstruir uma vida africana em liberdade, ou seja, prevalece uma concepção "palmarina" do quilombo enquanto sociedade alternativa. Um grande número de quilombos, talvez a maioria, não foi assim. Os fugidos eram poucos, se estabeleciam próximos a povoações, fazendas, engenhos, lavras, às vezes nas imediações de importantes centros urbanos, e mantinham relações ora conflituosas, ora amistosas, com diferentes membros da sociedade envolvente. Sociedade envolvente e também absorvente, no sentido de que os quilombolas circulavam com frequiência entre seus quilombos e os espaços "legítimos" da escravidão.
\end{abstract}

Concomitante ao mito do isolamento dos quilombos, foi forjado historicamente o mito de que sua existência se restringiu ao período escravocrata. No entanto, muitos quilombos se constituíram ou se reconfiguraram no contexto pós-abolição, como foi o caso de diversos quilombos urbanos que continuaram a existir, porém sofrendo transformações. Conforme alerta Rolnik (1989/2009, p. 78), quilombos urbanos eram “[...] locais ou eram cômodos e casas coletivas no centro da cidade ou núcleos semi-rurais - as roças das periferias urbanas [...]”. Eles foram se configurando pela presença da população negra nas cidades, em cortiços em áreas centrais e, primordialmente, nas periferias:

Os quilombos urbanos são formados, principalmente, por grupos que viviam ao redor de grandes cidades e foram englobados pelo crescimento urbano dos municípios, além de populações que habitavam áreas valorizadas nas cidades e que, a partir do século $\mathrm{XX}$, foram obrigados a se deslocar para áreas de periferia para dar lugar a projetos de revitalização e embelezamento ${ }^{30}$.

\footnotetext{
${ }^{29}$ Descobertas arqueológicas no Quilombo de Palmares revelam que não era isolado, pois mantinha relações com grupos ao seu entorno. Cf. FUNARI (1996).

${ }^{30}$ Texto extraído na íntegra do artigo “Quilombos Urbanos no Brasil: desafios e expectativas”. Disponível em: <http://www.ciranda.net/Quilombos-urbanos-no-Brasil?lang=fr>. Acesso em: 28 out. 2017.
} 
Com o crescimento das cidades, áreas antes periféricas, ocupadas por núcleos negros, passaram a ser centrais e, portanto, valorizadas. Os projetos de urbanização, frutos de uma política de embelezamento das cidades, adotaram como medida o deslocamento de parte importante desse grupo étnico-racial para áreas periféricas e esses quilombos foram se reconfigurando a partir de projetos de urbanização que mantinham sua marginalização.

As reflexões de Rolnik (1989/2009), ao refletir sobre a inserção da população negra nas cidades, nos permitem compreender o processo de configuração de núcleos negros urbanos, denominados "territórios negros". Segundo a autora, houve um projeto de segregação racial implementado historicamente nas cidades de São Paulo e Rio de Janeiro. Na perspectiva da autora, no caso da cidade de São Paulo, desde as primeiras décadas do século XX, o projeto de segregação urbana se configurou por meio de zoneamento social em que os abastados da sociedade abandonaram o centro da cidade e se fixaram em loteamentos com residências circundadas com muros e jardins. A população negra que habitava os cortiços, por sua vez, passou a residir também nos porões no centro da cidade "esvaziado" e em locais próximos às novas zonas habitadas por ricos.

Esse deslocamento para as zonas onde habitavam os ricos se explica pela adesão ao trabalho doméstico, uma vez que a mão de obra do imigrante europeu ${ }^{31}$ veio substituir a população negra nos trabalhos artesanal e manufatureiro. Sem oportunidade de emprego assalariado no comércio e nas indústrias, esses núcleos negros acabaram sendo caracterizados pejorativamente como redutos de marginais e de desclassificados:

Sua marginalidade era identificada com a não-proletarização de sua população, o que é imediatamente associado à idéia de desorganização, uma vez que a ocasionalidade da distribuição dos tempos de trabalho e lazer contrasta com a disciplina e regularidade do trabalho assalariado. A imagem de marginalidade é também identificada como própria da habitação coletiva: a intensidade de uma vida em grupo não-familiar e a densidade dos contatos no dia-a-dia do cortiço contrastam com a organização da casa burguesa (familiar, isolada, internamente dividida em cômodos com funções e habitantes segregados). Finalmente, a marginalidade é associada a um conjunto de gestos, um jeito de corpo. Se, para a comunidade negra, a linguagem do corpo é elemento de ligação e sustentação do código coletivo que institui a comunidade, para a classe dominante branca e cristã, a freqüência com que se dança, umbiga, requebra e abraça publicamente desafia os padrões morais. A presença dos terreiros e práticas religiosas africanas completa o estigma: candomblé é marginal

\footnotetext{
${ }^{31} \mathrm{O}$ grande contingente de mão de obra europeia no Brasil no período pós-abolição correspondeu ao ideal de construção da nação brasileira em moldes europeus. Assim, houve elaboração de discursos baseados em teorias raciais que buscavam enaltecer a cultura europeia, tida como superior, na crença de que ajudaria no progresso cultural e étnico, pois através da miscigenação seria possível extirpar o elemento negro, tido como inferior e fadado à bestialidade da escravidão.
} 
porque é "crendice", é "religião primitiva", que afronta a religião oficial (ROLNIK, 1989/2009, p. 81).

A exclusão da população negra do mercado de trabalho ocorreu concomitantemente à exclusão geográfica que foi sendo intensificada com as redefinições territorial/racial nos grandes centros urbanos através de projetos de intervenção, cuja finalidade era remodelar o espaço urbano aos moldes de cidades europeias e viabilizar o isolamento da população negra (OLIVEIRA, 2008; ROLNIK, 1989/2009). Nesse contexto, conforme a autora, essa população foi desalojada dos centros antigos da cidade e obrigada a se deslocar para outros espaços mais periféricos, o que resultou na ocupação de morros e territórios insalubres, como a várzea de rios, levando à formação das favelas. É neste sentido que se pode dizer que muitos "territórios negros" estão concentrados contemporaneamente no interior das favelas:

O compound $^{32}$ semi-rural que caracterizava o território negro nos subúrbios e morros que circundavam a cidade, no final do século [XIX], vai dar lugar, então, à habitação densa do morro, que será, a partir daí o território mais caracterizadamente negro [...] (ROLNIK, 1989/2009, p. 83).

Esses "territórios negros" guardam em seu interior manifestações culturais como as práticas de jongo, macumba, samba de roda, capoeira, culto aos Orixás. Embora tenham sofrido intensas repressões e perseguições, essas manifestações floresceram nesses espaços que, ainda hoje, mesmo estigmatizados, resistem em demarcar sua identidade guardando e reproduzindo aspectos importantes da cultura afro-brasileira. Dessa forma, "[...] ao falarmos de "territórios negros", estamos contando não apenas uma história de exclusão, mas também de construção de singularidade e elaboração de um repertório comum"33.

Ao mobilizarem aspectos específicos das culturas africana e afro-brasileira, essas comunidades revelam o caráter dinâmico da cultura, pois se mostram capazes de recriar especificidades mesmo mediante processos de segregação e dinâmicas de transformações urbanas. Tais especificidades denotam a ascendência majoritariamente negra dessas comunidades e torna mais visível a fronteira existente entre esse grupo social e aqueles que o circundam. Vemos, portanto, que esta fronteira é caracterizada tanto por diferenças culturais quanto sociais. Ressaltamos que esses espaços/territórios negros urbanos são compostos por

\footnotetext{
32 "O compound (como é denominado nos países africanos de língua inglesa), ou collectivité (nos de língua francesa), compõe-se de uma série de cômodos contíguos que dão para um pátio ou quintal comum. É geralmente habitado por uma família extensa" (ROLNIK, 1989/2009, p. 83.)

${ }^{33}$ Ibid., p. 76.
} 
grupos sociais de diferentes origens, mas sua dinâmica cultural e social é determinada pelo grupo étnico racial negro que representa a maioria.

Muitos núcleos negros surgiram a partir da reconfiguração do espaço urbano como, por exemplo, Liberdade, em Salvador; Gamboa e Serrinha, no Rio de Janeiro; e Bexiga ${ }^{34}$ e Barra Funda, em São Paulo. Essas localidades guardam especificidades culturais que possibilitam sua identificação como território urbano quilombola, em conformidade com o Decreto $\mathrm{n}^{\circ}$ 4.887/ 2003. Este decreto definiu juridicamente o que são (ou o que seriam) remanescentes das comunidades dos quilombos e estabeleceu os critérios para a regularização de terras quilombolas na medida em que alterou a abrangência do art. 68 do ADCT da Constituição de 1988, que se limitou a atribuir a propriedade definitiva das terras aos remanescentes quilombolas que as estivessem ocupando na data da promulgação da Constituição (05 de outubro de 1988$)^{35}$.

Ao identificar as resistências culturais africana e afro-brasileira como características quilombolas, esse decreto permite que grupos negros urbanos sejam reconhecidos como quilombos. Na definição das áreas como remanescentes de quilombos passa-se a considerar a presença de manifestações culturais que revelam um elo com o passado histórico, levando em conta a mobilidade desses grupos ao longo do tempo. Tal definição não se pauta apenas no território efetivamente ocupado pelos remanescentes, mas no conceito de autoatribuição ${ }^{36}$, critério que passou a determinar o processo de regularização e reconhecimento dos quilombos, abrindo caminho para que várias comunidades pudessem encaminhar pedido de reconhecimento de seu território como quilombo.

A emergência dessas comunidades quilombolas em contexto urbano ${ }^{37}$ revela que a quantidade de sítios quilombolas formados no Brasil da colônia e Império é muito maior do que

\footnotetext{
${ }^{34} \mathrm{O}$ núcleo negro do bairro do Bexiga é um exemplo, dentre outros que se originaram de antigos quilombos. Esse bairro é originário do quilombo Saracura, que se constituiu no final do século XIX às margens de um córrego do mesmo nome. O bairro do Bexiga é denominado oficialmente como bairro do Bela Vista. Cf. ROLNIK (1989/2009) e Nascimento (2014).
}

${ }^{35} \mathrm{O}$ Decreto $\mathrm{n}^{\mathrm{o}} 4.887 / 2003$ revogou o Decreto $\mathrm{n}^{\circ} 3.912 / 2001$ que previa o reconhecimento do direito à titulação em conformidade com o Art. 68 .

${ }^{36}$ Até 2017, existiam mais de 3000 mil comunidades quilombolas no país certificadas pela Fundação Palmares e cerca de 240 processos em análise, aguardando complementação de documentação ou visita técnica de certificação (Cf. Fundação Palmares. Disponível em: http://www.palmares.gov.br/comunidades-remanescentes-de-quilomboscrqs. Acesso em: 18 nov. 2017).

\footnotetext{
${ }^{37}$ No início do ano de 2007, um mapeamento dos quilombos urbanos no Brasil, realizado por membros do INCRA, da SEPPIR e do Ministério das Cidades, evidenciou que havia 44 quilombos urbanos e somente um total de nove reconhecidos e com processo de regularização fundiária aberto no INCRA (Instituto Nacional de colonização e reforma agrária). O primeiro quilombo urbano a ser reconhecido foi Quilombo de Brotas na região de Campinas,
} 
se imaginava, além de colaborar com o questionamento do mito do isolamento geográfico presente no imaginário social sobre quilombo. Esses "territórios negros" urbanos não possuem necessariamente distância geográfica com relação aos centros urbanos, mas uma distância social com relação a outros grupos sociais, considerando a equidade de direitos. Nesse sentido, as peculiaridades presentes nessas comunidades demonstram a continuidade da desfiliação social histórica impingida à população negra e, em contrapartida, sua resistência aos processos de opressão. Assim, o olhar para essas comunidades deflagra politicamente um repensar sobre a consequência da hierarquização racial na formação territorial brasileira.

Para Carril (2006a, p. 166), o surgimento de agrupamentos urbanos que se autoidentificam como quilombolas nos coloca frente ao desafio de interpretar a realidade dessas formações sociais, inclusive através de sua comparação com os quilombos rurais tradicionais. No contexto urbano, a fragmentação das formas sociais, étnicas e culturais é mais intensa, impondo hostilidade à população negra, pois no meio “[...] urbano, não se planta, não se pesca e nem se coletam frutos da mata. Na cidade fragmentada, os grupos se solidarizam para recuperar a autoestima em situações de marginalização social". No entanto, embora os quilombos rurais e urbanos se diferenciem em termos de espacialidade, segundo a autora, há algo que os unifica: a construção da identidade em meio à resistência e à escassez.

Embora cada quilombo tenha uma configuração histórico-cultural específica, sejam rurais ou urbanos, os quilombos carecem de infraestrutura básica, bens de serviço, trabalho e renda, o que é expressão da desigualdade social, fruto, por sua vez, da opressão histórica do grupo étnico-racial negro. Ainda que se considere a especificidade da construção da identidade em cada contexto, as novas formas de organização são delineadas tendo por base uma mesma revolta que se erige contra a hostilidade a que a população negra se encontra historicamente submetida.

Assim, ressaltamos que a concentração marginal da população negra no contexto social é consequência de uma política que contraria sua inserção social e a submete a um intenso processo de desapropriação e desenraizamento territoriais. Tal processo, que abrange a marginalização dos lugares ocupados - senzalas, quilombos, cortiços, favelas -, incide na consolidação desta população como coletivo subalterno. Entendemos que há uma correlação

SP, em 2004 pelo Instituto de Terras do Estado de São Paulo (Itesp). No entanto, o primeiro a ser titulado foi o Quilombo da Família Silva, localizado em Porto Alegre (RS), em 2007, e o segundo foi o Quilombo Chácara das Rosas, em Canoas (RS), em 2009. Além da comunidade Família Silva, atualmente se conhece a existência de mais quatro comunidades quilombolas no município de Porto Alegre: Alpes; Areal da Baronesa; Comunidade quilombola da Vila dos Sargentos; e Família Fidélix. Minas Gerais conta com o maior número de comunidades urbanas, entre elas a comunidades de Luízes e Mangueiras (Belo Horizonte), além de Baú (Araçuaí), Arturos (Contagem), Bairro Palmeiras (Teófilo Otoni), Tabatinga (Bom Despacho), Amaros (Paracatu), entre outros. 
simbólica e material entre cortiço, quilombo e favela, ou, conforme assinala Carril (2006b), entre quilombo e periferia. Segundo a autora, a não inserção social da população negra, após a Abolição, sobretudo no mercado de trabalho, deixou-a sem condições de produzir seus meios de subsistência e moradia, pois não possuía trabalho nem terra própria ${ }^{38}$. Assim, “[...] a reprodução dos seus meios de vida ficou condicionada às formas de superexploração, e as opções de moradia foram os cortiços e as favelas [...]" (CARRIL, 2006b, p. 58). Nesses espaços sulbaternizados a população negra forjou estratégias de sobrevivência e resistência, reelaborando coletivamente suas identidades e suas experiências sociais e culturais.

Cunha Junior (2007) alerta para a importância de se pensar espaços urbanos como construção sócio histórica e suas correlações com a pobreza urbana dos afrodescendentes. Segundo o autor, a análise da pobreza deve ser feita de modo desnaturalizado, sem o uso de generalizações, pois esta tem construção específica para cada espaço geográfico e população. Sendo assim, a pobreza não pode ser considerada como decorrente das ineficiências individual ou familiar, mas como uma produção proposital de políticas públicas. A pobreza “[...] não atinge igualmente e indiscriminadamente todos os grupos étnicos; existe substancial particularidade na produção da pobreza entre os afrodescendentes" (CUNHA JUNIOR, 2007, p. 73).

A especificidade da pobreza que atinge os afrodescendentes deve ser compreendida como construção histórica produzida por políticas públicas que visavam privilegiar eurodescendentes e desqualificar os afrodescendentes. A construção de políticas urbanas produtoras de desigualdades sociais, forjadas desde o escravismo, persistiram no contexto pósabolição atualizadas pelo racismo, agente estrutural que condiciona e limita as possibilidades de vida da população negra.

Ao deslegitimar a cultura, a história e a memória do segmento negro, a política de subalternização engendrada socialmente transforma espaços/territórios negros em ilegítimos. Ou seja, a inferiorização das manifestações culturais afro-brasileiras reforça o caráter marginal dos espaços habitados por esta população. Em contrapartida, a luta por reconhecimento de uma comunidade como remanescente de quilombo revela a resistência a esse projeto de subalternização, enquanto tentativa de ressignificação desse "não-lugar" e, sobretudo em contexto urbano, explicita a exclusão social na geografia espacial das cidades.

\footnotetext{
${ }^{38}$ A lei de terras de 1850 foi criada para que, mesmo após a abolição, os negros continuassem impedidos de possuir terras e para garantir que a população negra continuasse a servir de mão-de-obra aos grandes latifundiários. Segundo Carril (2006b, p. 58) a referida lei “[...] promoveu a separação entre os que têm condições de acesso à propriedade da terra, como mercadoria e os não-proprietários".
} 
Ao reivindicar o reconhecimento do seu território, uma comunidade quilombola está reivindicando o reconhecimento de enraizamento, ainda que "[...] o tema territorialidade no urbano indica menos terra comunitária nos lugares de encontro e mais manifestações culturais auto-identificadas" (CARRIL, 2006b, p. 41). Tais manifestações não se limitam a conteúdos culturais que demarcam diferenças, incluem a contraposição a lógicas excludentes. Assim, o quilombo se constituiu e continua a se constituir como resistência, e sua emergência em contexto urbano denuncia a segregação social-racial expressa na morfologia das cidades. Ao se mobilizarem, esses grupos politizam a relação entre identidade-território-cultura-resistências.

A noção de território ultrapassa, portanto, a dimensão de espaço geográfico, sobretudo no quilombo urbano onde não há uso comum da terra, no sentido de se plantar e colher, onde os contextos familiares parecem menos definidos e, por isso, há uma complexidade maior em seu reconhecimento, demarcação e em relação à própria construção de identidade territorial. A mobilização traz novas possibilidades à condição de "ser negro" e de "ser quilombola", requerendo redefinições que se estabelecem, no decorrer desse processo, em torno de suas necessidades. O sentimento de pertencimento ganha forma com um projeto de construção coletiva de comunidade, diante de uma organização social que implica em reconstrução da identidade e da territorialização. Neste sentido, território e identidade são, em certa medida, indissociáveis, no contexto rural ou no urbano.

A construção da identidade territorial tem um longo caminho e é preciso selecionar símbolos comuns que permitam estabelecer o pertencimento ao lugar e delinear fronteiras que ressaltem sua distinção em relação a outros grupos sociais. Nesse aspecto, é importante ressaltar que essa construção é fundamentalmente histórica, sociológica e subjetiva, pois se estabelece por meio da constituição de vínculos e pertencimentos, muito embora, em alguns casos, seja um processo deflagrado de modo objetivo através da atribuição do rótulo jurídico "remanescente de quilombos". Esse movimento tem relação com a dimensão étnico-racial e com a ascendência negra, envolvendo principalmente elementos constitutivos da identidade do grupo, como suas manifestações e organização social e ocorre na constante dialética onde o território é produto e produtor de identidade e esta é produto e produtora do território. 


\title{
2.3. Barro Preto: um bairro periférico urbano e seu reconhecimento como comunidade remanescente de quilombo
}

\begin{abstract}
“Quilombo em um lugar urbano?”. Tem esse preconceito. Mas aqui não foi o quilombo que entrou em meio urbano, mas foi o urbano que entrou no quilombo._Porque aqui, como era um lugar mais afastado, não exatamente rural, mas era mais afastado. Depois, com o tempo, com a expansão do manto urbano, que aqui foi abarcado. Foi dessa forma.
\end{abstract}

(Dudu).

O quilombo Barro Preto é um quilombo urbano, inserido na cidade de Jequié ${ }^{39}$, em uma região periférica. O surgimento de quilombos urbanos aponta desafios ao entendimento de suas características e demandas, assim como seu enquadramento em questões de direito, tendo em vista o artigo 68 e os demais instrumentos jurídicos que envolvem a questão das comunidades quilombolas. A Constituição de 1988 não findou com o estereótipo de quilombo cunhado no imaginário pós-colonial de grupos isolados, formados por negros fugidos restritos a áreas rurais, cuja resistência é vista de maneira petrificada em correspondência à negação ao sistema escravista.

As diversas formas de existência e organização dos quilombos trazem possibilidades de ressemantização do termo, considerando as especificidades de cada realidade e seu percurso, em um movimento contínuo e intercambiável, pois evidenciam que "[...] os quilombos nem sempre foram constituídos a partir de movimentos de insurrecionais ou rebelados, mas, sobretudo através de práticas cotidianas de resistência na manutenção e reprodução de seus modos de vida característicos e na consolidação de um território próprio”. (O’ DWYER, 2008, p. 10). A noção de remanescente de quilombo é reorientada a partir do Decreto $n^{\circ} 4.887 / 2003$ :

\begin{abstract}
Esta nova legislação dispensa a exigência de comprovação documental da descendência de escravos fugidos e da posse histórica ininterrupta sobre o território, desde a abolição da escravatura até a promulgação da Constituição de 1988. O novo decreto leva em consideração a impossibilidade de comprovação histórico documental, porque as comunidades se deslocavam constantemente em virtude de invasões e conflitos por terra promovidos por grileiros e fazendeiros e institui a autoatribuição como critério primordial. (MARINHO, p. 646, 2010).
\end{abstract}

\footnotetext{
${ }^{39}$ A área que corresponde hoje a Jequié fez parte do latifúndio Fazenda Borda da Mata. Essa fazenda pertencia a José de Sá Bittencourt, que a teria ganho do capitão-mor João Gonçalves da Costa (ARAUJO, 1971 apud MARCELO, 2002). Após a morte de José de Bittencourt, em 1832, a propriedade foi dívida entre seus herdeiros e a área que corresponde a Jequié - Barra de Jequié - ficou com seu filho José de Sá Bittencourt e Câmara que, mais tarde, a vende para Joaquim Fernandes da Silva. Sob o domínio desse último, o povoado ganha dinamicidade com a venda de lotes e abertura de estradas, tornando-se um pequeno centro de trocas comerciais (SANTOS, 1956 apud MARCELO, 2002). Em 1880, o povoado de Jequié é elevado à categoria de Distrito de Maracás; passa a receber imigrantes italianos, se moderniza e começa a haver um maior desenvolvimento do setor comercial. Em 1910, Jequié passa à categoria de cidade. Em 1914, uma enchente destrói quase todo o núcleo urbano, ocasionando a locomoção do centro urbano e, portanto, do comércio para as partes mais altas da cidade (ARAUJO, 1971 apud MARCELO, 2002). (Cf. ARAÚJO, Emerson P. História de Jequié. Salvador: Imprensa Oficial da Bahia. 1971. 173p.; SANTOS, Milton. A cidade de Jequié e sua Região. Revista Brasileira de Geografia, Rio de Janeiro, v.18, n.1, p. 71-112, 1956).
} 
Esse instrumento jurídico, ao deliberar quilombos como "grupos étnicos", possibilita o reconhecimento de diferentes formas de organização e suas dinâmicas particulares e nesse viés se torna possível o reconhecimento de grupos urbanos como comunidades remanescentes de quilombos. Embora distintas, as comunidades quilombolas rurais e urbanas têm como características comumente presentes: dificuldades para a efetivação de seus direitos e atendimento de suas demandas religiosas ou de ancestralidade; reivindicação da mesma origem e dividas históricas; serem compostas quase exclusivamente por pessoas que são vítimas de estigmas raciais e discriminações raciais. Os quilombos urbanos possuem uma base territorial marginalizada dos investimentos urbanos e estão marcados pelo alto índice de violência, pela presença de moradias inadequadas, pela falta de emprego, enfim, pela injustiça social que lhe impõe um imaginário social de exclusão e marginalidade. (CARRIL, 2006a).

O quilombo Barro Preto formou-se a partir do agrupamento de 600 garimpeiros negros que vieram da região de Maracás (Recôncavo Baiano) ${ }^{40}$ para trabalhar na construção da Estrada de Ferro Nazaré. A construção dessa estrada de ferro, no ano de 1914, contribuiu para a modernização e urbanização da cidade de Jequié e, além disso, a consolidou como lugar de destaque no comércio e circulação de mercadorias e pessoas (MARCELO, 2002; SANTOS, 2009). Segundo relato dos entrevistados, estes garimpeiros moravam em pequenas habitações, conhecidas como "Abarracamento", situadas distantes do centro urbano.

\footnotetext{
Maria: A gente tem dois pontos históricos aqui, que a gente gostaria que fosse transformado em patrimônio, a Caixa d'água e o Abarracamento, os dois contam a mesma história... Abarracamento foram as casas... Porque o bairro foi construído assim, a partir da construção da estrada de ferro que vem de Nazaré das Farinhas ((um município do Estado da Bahia)). Então, existe uma rua, hoje chama rua da linha, que era onde o trem passava. Esta Caixa d'água era onde o trem parava para encher as caldeiras de agua e esse Abarracamento são as casinhas, uma grudadinha na outra, onde esses negros ficavam, onde guardavam as coisas, né? [...] Elas foram construídas para esses trabalhadores negros ficarem e guardarem suas coisas, eram divididas porque acreditamos nós que vieram com suas famílias. Então, está aqui até hoje, é por isso que a gente gostaria que ele fosse um patrimônio do bairro, né? Hoje continua do mesmo jeito... A gente fez um documento... Então, a gente teve que estudar o bairro. E ele foi construído dessa forma. Os contratantes ficavam no centro da cidade, aqui era bairro, né? ... Então, construíam essa... bem longe, esses negros ficavam bem longe do centro da cidade. Eles fixavam nessas casinhas, construindo essa linha de ferro por onde o trem passava. E a Caixa d'água, é uma caixa d'água mesmo, enorme, era onde enchia as caldeiras de água quando o trem passava. Mais para frente, que já não é mais o centro da cidade, já é São Luiz, a gente tem o bairro Estação, que é onde era a estação que hoje é o corpo de bombeiro. A casa continua lá, que era a estação do trem. Então, a gente estudou, até porque a gente queria que esses dois monumentos se transformassem em nosso patrimônio do bairro, mas a gente ainda não conseguiu. Por que a gente ainda não conseguiu? Porque esses moradores ainda não reconhecem esse lugar como um patrimônio contador de história.
}

\footnotetext{
${ }^{40}$ Maracás: município que faz fronteira ao norte com a cidade de Jequié.
} 
Sua formação, a exemplo de outros quilombos urbanos, está ligada a um processo de segregação espacial, à margem de benefícios e com pouca possibilidade de mobilidade dentro do espaço. Ressaltamos, no entanto, seu aspecto de resistência pela luta de seus habitantes em constituir um território como local de moradia. Além do "Abarracamento", a depoente faz referência a outra construção histórica que ainda sobrevive ao tempo, a "Caixa d'água". Segundo a entrevistada, foi elaborado um documento pela escola solicitando a transformação dessas construções em patrimônio histórico do quilombo Barro Preto.

Esta solicitação ainda não foi atendida e, segundo Maria, a não valorização dessas construções, pela maioria dos membros da comunidade, é um fator que dificulta seu reconhecimento como patrimônio histórico. Segundo os relatos obtidos em campo de pesquisa, o bairro teria esse nome em função de seus primeiros moradores serem negros retintos; outros contam que o nome decorre da existência de uma terra (barro/argila) de cor preta nessa localidade; e há, ainda, uma outra versão, segunda a qual o nome tem relação com a cinzas de carvão que o trem descarregava na estação.

Figura 1: Fotografia do Abarracamento

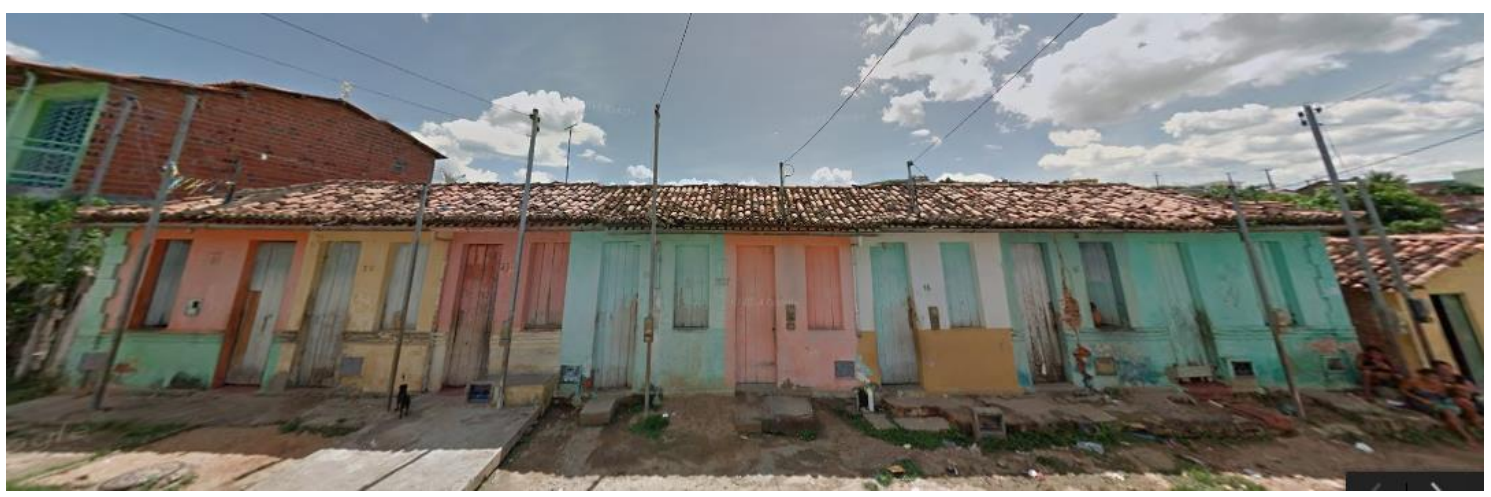

Fonte: Google Mapas. ${ }^{41}$

O processo de reconhecimento dessa comunidade como remanescente de quilombo foi desencadeado a partir de uma pesquisa de mestrado, "A Reestruturação Urbana Regional de Jequié-Bahia" (2002), desenvolvida por Valter Luiz dos Santos Marcelo, no Curso de PósGraduação em Geografia da Universidade Federal da Bahia (UFBA). Segundo Marcelo (2002, p. 41-42), o Bairro Barro Preto foi “[...] formado por 600 garimpeiros negros, que trabalhavam na construção da Estrada de Ferro, atualmente o bairro é denominado Duque de Caxias, e só

\footnotetext{
${ }^{41}$ Para visualizar a construção e conhecer o bairro Barro Preto, segue link de acesso - Google Mapas. Disponível em: <https://www.google.com.br/maps/@-13.8469767,40.0924881,3a,75y,219.93h,74.63t/data=!3m6!1e1!3m4!1syXK5JgQpnhc_TbZq9EcDew!2e0!7i13312!8i6656.> Acesso em: 31 out. 2017> Acesso em: 06 nov. 2017.
} 
durante os anos de 1990 recebeu infraestrutura urbana"42. Marcelo (2002) assinala que, nas primeiras décadas do século XX, novos núcleos urbanos são construídos, na cidade de Jequié, em função da chegada da Estrada de Ferro Nazaré, entre eles o bairro Barro Preto ${ }^{43}$.

A ferrovia parte da cidade de Nazaré, em 1871, e chega a Jequié em 1927, que então passa a se ligar ao Recôncavo Baiano e a Salvador. O autor ressalta que a ferrovia trouxe maior crescimento do comércio e atividades de serviço, mas não teve grande impacto no crescimento da cidade "[...] principalmente no entorno da Estação Ferroviária, pois os terrenos foram loteados e colocados à venda, o que possivelmente contribuiu na demora de sua ocupação, uma vez que a população de baixo poder aquisitivo não pode ocupar esta área. Na proximidade da Estação existia apenas um pequeno número de trabalhadores da ferrovia, onde alguns comerciantes instalaram armazéns e escritórios comerciais" (MARCELO, 2002, p. 42).

O mesmo autor explica, ainda, que a expansão da rodovia BR-116, a partir da década de 1940, ocasionou maior desenvolvimento de atividades comerciais e serviços no centro da cidade e em seu entorno, levando ao crescimento urbano, com surgimento de novos bairros e ruas, e ampliando outros, a exemplo do bairro Barro Preto. Segundo informações do jornalista Francisco ${ }^{44}$ e com base nos indícios fornecidos pelo trabalho de Marcelo (2002), formou-se um

\footnotetext{
${ }^{42}$ Em contato através de $e$-mail, o autor referiu que obteve essas informações através de dois jornalistas, Eusinio Soares e Eunisio, já falecidos. Acrescentou que esses trabalhadores negros eram oriundos do Recôncavo e contextualizou historicamente a construção da linha de ferro - " $[$...] O período de abertura da ferrovia é nas primeiras décadas do século XX, logo pós 'extinção do trabalho escravo' e início do trabalho assalariado, especificamente no campo, por outro lado o território baiano passava por um período de perdas políticas - com a transferência da capital para o Rio de Janeiro e perdas econômicas com a crise na produção da cana de açúcar. Por outro lado, ocorria interiorização da população e um dos elementos que contribuirão foram as aberturas das vias de transportes, para esse momento o transporte ferroviário" (MARCELO, 2017, informação pessoal). Informações recebidas por $e$-mail em 06 nov. 2017.
}

${ }^{43}$ Oscar Santana dos Santos (2011), em sua Dissertação de Mestrado, intitulada Uma viagem histórica pelas Estradas da Esperança: representações literárias do cotidiano, da região e da desativação da Estrada de Ferro Nazaré (Bahia, 19601971), faz uma análise do romance, As estradas da Esperança, de Antônio Leal de Santa Inez (1982). Segundo Santos (2011), o romance é uma narrativa da vida dos passageiros do trem que percorria a Estrada de Ferro de Nazaré e constitui uma interpretação da memória do autor, sendo, portanto, fonte histórica importante sobre a história dessa ferrovia. Conforme o autor, Antônio Leal utiliza-se de nomes reais das cidades e dos povoados por onde a ferrovia passava. Entre os nomes de povoados, Antônio Leal cita Barro Preto: “As ruas da periferia apresentavam enormes valetas, erosão no barro vermelho do que seria a calçada. A Rua Rio de Contas, a Gameleira, a Ladeira do 29, mesmo o Maracujá, de tantos pecados, tudo era sujo, pobre e esburacado. E nem se precisa falar na pobreza do Barro Preto, da Caixinha das Almas, do Mandacaru. Mas havia o trem. Jequié era porta do sertão. Era e é. Hoje, bonita e cuidada, asfaltada e limpa, já não se lembra a falta de água e de luz, mas ainda guarda algumas palhoças, nas pontas de ruas distantes, onde se dançava o pó de palha e de onde vinham os moleques esfarrapados que, por um níquel, guardavam o lugar no trem para os passageiros importantes que se levantavam na madrugada" (SANTA INEZ, 1982, p. 21-22 apud SANTOS, 2011, p. 43, itálico nosso). Cf. SANTA INEZ, Antônio Leal de. As Estradas da Esperança. São Paulo: Clube do Livro, 1982.

${ }^{44}$ Francisco integrou a comissão responsável pelo encaminhamento das documentações enviadas à Fundação Palmares. Segundo ele, essa comissão foi formada por pessoas ligadas a órgãos sociais de Jequié como, por exemplo, a Associação de Moradores, a Associação de Terreiros de Candomblé, a Secretaria Municipal de Educação, Universidade Estadual da Bahia (UESB), o Colégio Milton Santos, entre outros. 
grupo responsável pelo estudo e encaminhamento à Fundação Palmares das documentações necessárias para o processo de reconhecimento do bairro como quilombola. Após o envio da documentação e tramitação legal, foi emitida a certidão de reconhecimento desse território como comunidade remanescente de quilombo.

Os relatos dos entrevistados evidenciam que a identificação da comunidade de Barro Preto como quilombola pode ter ocorrido em função da observação de aspectos relacionados ao histórico de formação, organização e ocupação desse território. Muito embora os relatos e escritos históricos não revelem especificidades sobre esses aspectos, pode-se afirmar que essa comunidade não surgiu a partir de antigos quilombos, mas se inclui entre a diversidade de quilombos, cuja formação se estabelece mediante distintas modalidades de uso comum da terra (ALMEIDA, 1989). Para Francisco (jornalista, informação pessoal), foi o histórico de formação do bairro que trouxe evidências de que o mesmo poderia ser identificado como quilombo. Ele relata que há no bairro uma família de sobrenome "Gurunga", que seria descendente dos primeiros garimpeiros negros que vieram trabalhar na construção da estrada de ferro.

Segundo Francisco (informação pessoal), logo após o bairro receber o certificado de comunidade remanescente de quilombo, alguns membros integrantes do grupo, formado incialmente para o encaminhamento de documentações à Fundação Palmares, iniciaram uma pesquisa com os moradores para levantamento de dados que deveriam ser enviados a essa Fundação com a finalidade de fornecer informações importantes para o processo de demarcação desse território. Durante a referida pesquisa, foram realizadas entrevistas com os moradores, conforme assinala a diretora da escola Milton Santos, Manuela, em seu relato:

[...] tem também essa parte de pesquisa com os mais velhos, ela foi feita depois do reconhecimento, porque eu participei desse processo. Logo quando eu iniciei aqui em 2007, foi em 2008, nós fizemos entrevistas com os mais velhos aqui, tentamos montar, definir, quais seriam as ruas de fato que estariam pertencentes à comunidade quilombola.

As entrevistas, buscando indícios de "autorreconhecimento", foram realizadas posteriormente à emissão da certidão de reconhecimento. Ao ser questionada se percebeu "autorreconhecimento" a partir das falas dos moradores do bairro, Manuela responde:

Houve sim. Eles contavam relatos sobre a origem do povo aqui, eles se identificavam com a cultura africana, mesmo sem saber que estavam se identificando. $E$ um autorreconhecimento inconsciente, vamos colocar assim. Eles se percebiam com o legado africano e passando esse legado para seus filhos e netos, mas ainda com marcas muito branquiadas, sabe? É um pouco complicado, acho que um antropólogo, a gente estudando melhor para saber como de fato essas pessoas mais velhas se definem.

Observa-se, através do relato, que há indícios de uma identificação referente à ancestralidade negra, ancorada na formação histórica da comunidade, ainda que esses sinais 
característicos de uma autoidentificação possam parecer não demostrar um vínculo consciente com uma trajetória histórica.

Em termos de reconhecimento oficial, os instrumentos legais determinam que a autoatribuição seja empregada institucionalmente como elemento de identificação das comunidades remanescentes de quilombo. Esse direito foi regulamentado pelo Decreto $\mathrm{n}^{\mathrm{o}}$ 4887/2003, corroborado pela Convenção 169 , que, em seu artigo $1^{\circ}$, determina que "[...] a consciência de sua identidade indígena ou tribal deverá ser considerada como critério fundamental para determinar os grupos aos que se aplicam as disposições da presente Convenção". Importante mencionar que a partir desse decreto o laudo antropológico é dispensável, ocorrendo apenas em caso de contestação judicial da condição da comunidade como remanescente de quilombo.

Após o reconhecimento oficial da comunidade de Barro Preto foi criada a associação do bairro, a fim de conscientizar os moradores da importância de se reconhecerem como quilombolas, para que pudessem reivindicar os benefícios reconhecidos por direito à categoria "remanescente de quilombos". Em entrevista, o presidente da associação, na época do reconhecimento, relaciona as dificuldades na conquista de benefícios à negação dos moradores em se apropriarem do rótulo jurídico "remanescente de quilombo":

\footnotetext{
Pedro: [...] segundo o que muitas pessoas me falaram, outras pessoas estavam achando que isso era discriminação. Porque a população ainda não aderiu que isso aqui é quilombola. Acham que é uma discriminação sobre os negros, achando que eles são negros. "Acham que agora somos negros". Eu disse: "não, quilombola é uma comunidade. Onde no passado tinha todos os direitos que tem hoje e ele não usufruía de nada e hoje o Ministério da Cultura está devolvendo tudo aquilo que foi negado a eles no passado". Tanto que você vê, né? ...Quer igualdade. O que o branco tem direito o negro também tem e antigamente não era assim. E depois do reconhecimento eles estão devolvendo todas aquelas diretrizes que o negro tinha e agora a igualdade continua. E para te falar também da discriminação...continua ainda, porque a comunidade ainda não aderiu, por isso que esse projeto não avançou muito.
}

Segundo esta fala, muitos moradores sentem o reconhecimento como imposição de um rótulo, com o qual a comunidade não se identifica. Essa recusa em se autoidentificarem como quilombolas, entre outros fatores, pode estar relacionada a uma identificação negativa com o grupo étnico-racial negro decorrente da construção pejorativa atribuída historicamente a essa população. É possível que os moradores estejam compreendendo as expressões "negro" e "quilombo" como ofensivas, humilhantes e, ao se autoidentifacarem como quilombolas, estarão se assumindo enquanto negros, concordando em serem "discriminados", marcados socialmente com o estigma da inferioridade. 
Com relação à autoidentificação ou autoatribuição, é relevante ressaltar que a discussão não deve ser simplificada; deve-se considerar que este processo está ligado à possibilidade de conversões política e simbólica do conceito quilombo, à inversão de categorizações que estigmatizam e à ressignificação de sentidos negativos atribuídos socialmente ao termo "negro", "preto", ao próprio termo quilombo. Dessa forma, a autoatribuição do rótulo pode estar mais presente em comunidades já mobilizadas do que entre aquelas em fase de mobilização. No caso do bairro Barro Preto, podemos dizer que a comunidade se apresenta em processo de reconhecer-se enquanto quilombola. Neste ponto, ainda não houve apropriação, pela maioria dos membros da comunidade, do rótulo jurídico "remanescente de quilombo".

A autoatribuição é um processo de produção de identidade, envolve interações, negociações externas e internas à comunidade quilombola, a transformação de estigmas em marcas positivas das diferenças, a ressignificação e a incorporação de termos negados pelo grupo. A construção de uma identidade quilombola não se dá prontamente após o título recebido, é construída de maneira coletiva e processual, ou seja, através de um "processo quilombola" (ARRUTI, 2006, p. 45): "Um modelo processual quatripartido entre nominação, identificação, reconhecimento e territorialização. Cada um desses processos encontra-se empiricamente imbricado aos outros [...]".

Segundo o autor, o processo de nomeação trata de instituir como sujeitos de direitos aqueles pertencentes a uma dada comunidade, com determinadas características correspondentes à categoria "remanescente de quilombos", de acordo com o artigo 68 da Constituição Federal de 1988. Assim, o processo de identificação está ligado ao momento em que a comunidade percebe, mediante expectativas legais, a importância de aderir à designação "remanescente de quilombo", para que possa ser reconhecida e respaldada pelo Estado na garantia de direito. É o momento no qual as situações de opressão e exclusão da comunidade são reconhecidas pela sociedade e pelo Estado e, consequentemente, é reconhecida a necessidade legítima de reparação. Ligado a este processo está o de territorialização, que implica nas reorganizações social, política, econômica e cultural de um grupo em processo de fixação e delimitação espacial ${ }^{45}$.

Nesse contexto, pode-se dizer que o reconhecimento como quilombola fomenta elementos para a formação da identidade étnica, que se materializa de modo processual, “[...] pela referência histórica comum, construída a partir de vivência e valores partilhados" (ABA, 1994). Trata-se de uma identidade coletivamente construída através de relações estabelecidas

${ }^{45}$ Ibid., p. 46. 
com diferentes agentes e agenciamentos, onde referências culturais apresentam possibilidades de subversões, construções de fronteiras e, como indica Hall (2000, p. 108-109), "negociações com nossas rotas":

\begin{abstract}
As identidades parecem invocar uma origem que residiria em um passado histórico com o qual elas continuariam a manter uma certa correspondência. Elas têm a ver, entretanto, com a questão da utilização dos recursos da história, da linguagem e da cultura para a produção não daquilo que nós somos, mas daquilo no qual nos tornamos. Têm a ver não tanto com as questões - quem nós somos ou - de onde nós viemos, mas muito mais com as questões - quem nós podemos nos tornar, - como nós temos sido representados e - como essa representação afeta a forma como nós podemos representar a nós próprios. Elas têm tanto a ver com a invenção da tradição quanto com a própria tradição, a qual elas nos obrigam a ler não como uma incessante reiteração mas como - o mesmo que se transforma (GILROY, 1994): não o assim chamado - retorno às raízes, mas uma negociação com nossas - rotas. (itálico do autor).
\end{abstract}

Nessa perspectiva, a autoatribuição como remanescente de quilombo compreende um diálogo entre o presente e o passado, a coexistência entre o moderno e o tradicional, e se constitui como processo de identificação complexo, cujas narrativas identitárias se estabelecem de forma dinâmica, remetendo ao resgate da memória. Trata-se de um movimento gradual, marcado por tensões e conflitos construído externamente ao grupo e que carrega interpretações negativas do termo quilombo. Desta forma, a partir das entrevistas, podemos dizer que a comunidade Barro Preto encontra-se em fase de assimilação da categoria "remanescente de quilombo" e consideramos que a instituição escolar torna-se um espaço privilegiado para o processo de apropriação do termo pela possibilidade de empreender novos sentidos à designação quilombola, ressignificando estereótipos.

A percepção negativa sobre "o ser quilombola" entre moradores é evidenciada no relato de Pedro, quando se refere ao momento da escolha do nome da associação do bairro, sobre a resistência, por parte de alguns, à denominação da Associação dos Moradores de Barro Preto. Questionado pela pesquisadora sobre a identificação das pessoas do bairro como quilombolas, o entrevistado responde:

Não, exatamente porque vê que quilombolas é comunidade de preto, de negros... Porque aqui já tem o nome Barro Preto e eu não tirei o nome. Barro Preto por causa dessas cinzas da época do trem de ferro, né? Antes da eleição, nas reuniões que nós tivemos, o pessoal colocou: "Pedro, como é que vai ser o nome da associação?" "Vai ser Associação dos Moradores de Barro Preto". "Ah Não!” Eu disse: "Rapaz, a gente tem que tirar o preconceito". As pessoas têm que acostumar, todo bairro é direcionado a um sobrenome, se tirar aqui Barro Preto, não tira nunca. Que nome eu vou colocar nisso aqui? Já tem a Associação da Caixa d'água, aqui do lado. Associação de moradores Duque de Caxias? Eu estou direcionando o nome da associação a uma rua, não a uma comunidade. Que nome eu vou colocar? Eu falei: "Gente, vamos parar de besteira, nós moramos aqui há muitos e muitos anos. E isso aqui já existia há anos e anos. Nossos próprios pais nem moravam aqui, isso aqui já existia gente, depois é que viemos. Que preconceito besta é esse?" "Ah porque tudo o que acontece é Barro Preto" "E se botar Duque de Caxias, não vão falar tudo que acontece é na antiga Barro 
Preto, lá na Duque de Caxias?". Nós temos um campo ali do outro lado que o nome dele é... Andibal Pires... Sabe qual era o nome dele anteriormente? Cururu, e ninguém chama de Andibal Pires, é campo do Cururu e acabou, não tira. Não tem quem faz trocar nome de rua.

Nesse contexto, o nome Barro Preto ressaltou, na ótica dos moradores, ainda mais sua ligação ao grupo étnico-racial negro, o que, em parte, buscam negar. Em contraposição a essa recusa, acreditamos que o reconhecer-se como "remanescente de quilombo" passa pela positivação da negritude, para além do entendimento dos benefícios que se pode obter ao se assumirem como remanescentes de quilombo: é uma luta de resistência ideológica contra as construções negativas sobre o "ser negro".

Embora a escola tenha um papel fundamental na reconstrução do "ser negro" e "ser quilombola", uma organização política no bairro é de extrema importância nesse processo. Ao que podemos perceber, esta organização política encontra-se em fase de desenvolvimento na referida comunidade. Segundo os membros da associação que foram entrevistados, após o reconhecimento da comunidade como "remanescente de quilombo", as ações estavam sendo empreendidas de maneira dinâmica, com reuniões, debates e levantamento de dados, como, por exemplo, entrevistas realizadas com os moradores mais antigos, que possuíam entre 70 a 100 anos de idade.

No entanto, segundo os entrevistados, divergências internas fizeram com que o grupo de associados deixasse de ser coeso. Além disso, questões políticas, falta de apoio do poder municipal e de conscientização da comunidade também interferiram na capacidade da associação de se manter atuante após a emissão do certificado de reconhecimento.

Carlos: [...] Principal fator hoje, além dos benefícios que não chegam, é elevar esse conhecimento e essa conscientização, que ainda não tem. Muita gente ainda tem preconceito porque não tem esse conhecimento.

Pedro: Exatamente porque as pessoas da comunidade não vieram ajudar, por causa da discriminação e por motivo político também. Porque aqui quando tem um grupo que quer fazer algo de bom pelo quilombola, já entra outro grupo trazendo política para usufruir do quilombola.

Há ainda, dificuldade dos membros da associação na elaboração de projetos que poderiam beneficiar a comunidade e desconhecimento dos mecanismos necessários para a inscrição de projetos nos órgãos responsáveis. Carlos também refere a perda do apoio da diretora da escola na confecção dos projetos:

[...] Eu discutia isso com Manuela, que a gente tinha que ter um técnico, como ela tem no colégio. Porque ela faz os projetos para o colégio e é aprovado, vem. Mas o que a gente questionava era isso, a gente pedia esse apoio dela, nesse sentido de fazer um projeto. Porque os projetos lançam, mas a gente não tinha o conhecimento de quando lança...Não tinha uma equipe técnica, porque a gente trabalha, são pessoas 
comuns...Então, pelo fato dela participar de uma direção do colégio e ela já conhecer e buscar esses projetos a gente pedia dela, assim, que tivesse uma equipe que nos orientasse nesse sentido...de fazer projeto. Por exemplo, fazer um projeto para o campo do índio, fazer uma área desportiva, que tem campo de chão, entendeu? Fazer uma estrutura para o posto de saúde, a gente pedia, mas era muitas palavras e poucas ações, né? Tem que ter escrita, tudo certinho, documentação, ser legalizado...Ter uma pessoa técnica que realmente tenha conhecimento e sabe como funciona. E eu te falo, dentro da associação hoje a gente não tem ninguém capaz de fazer isso. Porque tem toda uma linguagem técnica e conhecimento...O que a gente tem hoje? Se você perguntar hoje o que a comunidade precisa e onde estão os problemas a gente vai te apontar, porque a gente vive isso aqui, mas nessa área aí, a gente não tem conhecimento. Então, a gente precisa de um suporte e era isso que a gente buscava, um suporte para a cultura dentro do bairro, projeto para esporte... Os benefícios só vêm para o colégio. O recurso que vem para a educação é um recurso diferenciado quilombola, os projetos que ela busca também são todos quilombolas, mas ela faz os projetos, ela tem uma equipe técnica que faz.

Por outro lado, a diretora mencionada afirma que não conta exatamente com uma “equipe técnica" para elaboração de projetos para requerer benefícios - os projetos realizados na escola são elaborados pela equipe gestora ou por grupos de apoio, como o ODERE, mas não contam com recursos recebidos em função do status quilombola. Ela relata que o único benefício que a escola recebe por ser quilombola corresponde ao acréscimo de trinta centavos, por aluno, para ser gasto com a merenda escolar, e que os demais recursos são semelhantes ao de qualquer outra escola.

Segundo Manuela, há programas como o "Mais Educação", criados pelo Ministério da Educação, nos quais toda escola pode se inscrever, independentemente de ser quilombola ou não e que, quando contemplada, os recursos financeiros são destinados a atividades relacionadas à aplicação dos projetos inscritos. Em entrevista, a diretora relata que era membro da associação e que se distanciou por falta de tempo hábil, diante das suas responsabilidades administrativas e pedagógicas.

\begin{abstract}
Manuela: [...] Aí, foi como eu the falei você vai cansando de ensinar o outro a fazer e precisa da parte burocrática, precisa de relatos escritos e eles têm essa dificuldade, em fazer ata, têm dificuldade em colocar no papel. [...]E eu não tenho tempo, quando eles pedem para mim esta parte legal toda comigo, só que eu tenho todas as tarefas da escola. Então, eu falei: "Gente, eu vou sair porque vocês precisam crescer. Eu acho que eu estou impedindo. Eu acho que eu sou a vaquinha, não tem a história da vaquinha? ...Eu sou a vaquinha que impede o crescimento. Eu vou sair". Aí, eu não fui mais a nenhuma reunião, deixei de frequentar as reuniões.
\end{abstract}

Hoje, a escola e a Associação de bairro fazem apenas um trabalho em conjunto: o de fornecer documentos comprobatórios e assinaturas para requerimento de benefícios como cotas para a universidade pública, entre outros:

Manuela: Alguém precisa atestar que você tem uma ancestralidade aqui no bairro. $\mathrm{E}$ quem é que atesta isso? É o presidente da associação do bairro. Eu faço a primeira etapa, você vem aqui eu vejo o seu endereço...Tem uns que eu já digo logo: "você não 
é aqui do bairro". Porque alguns eu já conheço. Mas o que teve de gente tentando lubridiar para poder conseguir as cotas é assim.... terrível. Tem muita gente que aluga a casa aqui para ter as cotas, ter acesso. Aí, quando a gente diz que não, que não tem, não quer aceitar. Aí eu faço a primeira etapa, preencho a documentação e mando para o presidente da associação de bairro, e o presidente da associação de bairro é quem atesta que ele tem raiz aqui na comunidade, que a família dele é daqui, que ele é filho de não sei quem e neto de fulano e por aí vai.

Além de uma associação fragilizada, a comunidade possui uma comissão quilombola não atuante - Pedro relata que há uma comissão quilombola formada para representar a comunidade de Barro Preto, mas que seu presidente não é membro da comunidade e não foi eleito pela mesma.

Esta pessoa teria sido indicada pelos membros integrantes da associação de bairro de maneira impositiva e improvisada, em um momento em que se fazia necessária a nomeação de um representante para participar de um encontro sobre questões quilombolas, em Brasília. Como nenhum deles poderia sair em viagem, houve a indicação. Segundo Pedro, esta pessoa é ausente, não reside na comunidade e, quando solicitada, não atende às demandas:

\footnotetext{
Não vejo nada que ele tem feito, um cara que não dá satisfação. Eu que fui representante da comunidade por quatro anos, que fiz meu sucessor, que ficamos seis anos na comunidade trabalhando por ela, se doando por ela...Um cara que entra pela janela, sem votação, sem ser escolhido pela comunidade, não dá as caras para a gente, você liga para o cara, o cara não atende. [...] A merda que deu foi isso aí. Ele se ausentou, reunião mais nenhuma, convoca-se e não aparece. Comissão malfeita, coisa sem pensar. Sabe o que foi? Fizeram por impulso, porque tinha que formar a comissão do quilombola. Ótimo, a comissão foi feita. Aí, depois bota ele ali seis meses, um ano formando a comissão e que se faça a diretoria depois, mas depois não foi feita. Aí, a quilombola está de lado perdendo, e perdendo benefícios. Porque tem projetos...Se você abre na internet aí, o que tem de projetos para uma comunidade de quilombolas, tem tudo...rede de farmácia, se você quiser colocar, quadra poliesportiva, colégio, saúde, tudo que você pensa vem. A diretoria tem que ser formada, toda ela documentada, entendeu?
}

A fala evidencia a necessidade da criação de uma diretoria quilombola composta por membros do bairro "Porque hoje não tem uma diretoria feita para que o Ministério da Cultura reconheça que realmente tem uma diretoria do quilombo urbano". Em outros momentos da entrevista, Pedro relatou sua expectativa de que a diretoria possa ser formada, após novas eleições no bairro, para a escolha de novos membros da associação dos moradores e da comissão quilombola. Segundo ele, esses representantes devem ser pessoas da comunidade, eleitas por meio do voto de moradores mais velhos que saibam das carências e dificuldades do bairro. 


\section{QUILOMBO: “O GRANDE NEGRO”.}

Ainda que se considere as múltiplas formas da existência de quilombos em terras brasileiras, assim como a presença de membros de diferentes grupos étnicos em sua composição, a experiência negra é algo que os unifica. A experiência de aquilombar-se é majoritariamente negra, pois deriva de um modelo de organização social forjado pela experiência histórica de africanos e seus descendentes ${ }^{46}$. Conforme assinalam Furtado, Pedroza e Alves (2014, p. 111), quilombo pode ser compreendido como uma "[...] manifestação típica da insubordinação negra [...] constituindo uma forma de sobrevivência e luta contra a escravidão diante das repressões evidenciadas".

Atualmente, os quilombos ainda demostram a tenacidade da população negra em tornar sua existência visível e reivindicar reconhecimento e direitos. O imaginário social sobre quilombo abrange um conjunto de representações sociais que circunscrevem o significante "negro" - o quilombo é depositário da experiência negra e, por conseguinte, do elemento negro e, nesse sentido, é um termo indissociável do termo negro.

\subsection{Implicações de "ser negro" no Brasil no processo de assumir-se quilombola}

A forma como as relações raciais se estabeleceram na sociedade brasileira nos auxilia a compreender as ambiguidades presentes em torno do significante "negro", características das ideologias raciais que especificam o "racismo à brasileira". Um racismo velado, que encontra no discurso da mestiçagem a roupagem necessária para dissimular processos de segregação e discriminação mantenedores de extrema desigualdade social. O mesmo se ancora no ideal de branqueamento para criar hierarquizações raciais baseadas em gradações da "cor”. Os discursos forjados historicamente pelo racismo servem para impedir e deteriorar a identificação do negro com a história e a cultura dos africanos e afro-brasileiros, desqualificando tudo o que pode ser identificado como sendo "negro", o que inclui o termo quilombo.

\footnotetext{
${ }^{46}$ Munanga (1995) explica que conceito de quilombo é originário da palavra Kilombo, advinda dos povos africanos bantus. Assim, podemos inferir que quilombo no Brasil se configura a partir da diáspora africana, sendo inspirado em agrupamentos de resistência, já constituídos nas sociedades africanas com o mesmo propósito - resistência e oposição à estrutura escravocrata. "Existem muitas semelhanças entre o quilombo africano e o brasileiro, formados mais ou menos na mesma época. Sendo assim, os quilombos brasileiros podem ser considerados como uma inspiração africana, reconstruída pelos escravizados para se opor à estrutura escravocrata, pela implantação de uma outra forma de vida, de uma outra estrutura política na qual se encontram todos os tipos oprimidos" (MUNANGA; GOMES, 2006, p. 71).
} 
O entendimento sobre o que é "ser quilombola" na sociedade brasileira implica, antes de tudo, reconhecer as ambiguidades e o constante exercício de construção e reconstrução do significante "negro", processo que se relaciona à negação, mas também à afirmação desta identidade social:

\begin{abstract}
No quadro das classificações sociais, a categoria "negro", no Brasil da transição do século XIX para o XX, assim como a expressão "quilombola", "preto" ou "afrobrasileiro", neste início de XXI, indica que um recorte de grupo vem se mantendo e persistindo em um longo período. Mesmo antes, quando o modo de produção colonial sustentado pela mão-de-obra escrava já esboçava o seu completo esgotamento, chegando logo depois a um ponto de verdadeira saturação, o que era identificado como sendo "negro" referia-se - mais do que isto, englobava - à experiência histórica dos africanos e seus descendentes, tratados nos séculos anteriores como sujeitos ahistóricos, negados em sua condição de humanidade. Enquanto uma expressão da identidade grupal, o significante "negro" vai somando em seu percurso tudo aquilo que advém de tal experiência, ou seja, elementos de inclusão (que mantêm o grupo unido em estratégias de solidariedade e reciprocidade), e também de segregação (ou seja: a desqualificação, a depreciação e a estereotipia). Os sentidos do termo e as experiências nele circunscritas revelam sua ambigüidade: por um lado, a marginalização; por outro, a força simbólica demonstrada no seu persistente poder aglutinador, vindo a configurar ou expressar uma identidade social, e a nortear inclusive políticas de grupos (LEITE, 2000, p. 342).
\end{abstract}

Os discursos sobre a mestiçagem sustentam o mito da democracia racial, tido como fundador da sociedade brasileira, o qual expressa a ideia de que "somos todos mestiços", comprovadamente pela "mistura" interétnica sendo, nessa medida, desnecessário identificar-se racialmente como negro, branco, entre outros. No entanto, sabe-se que a mestiçagem se fundamenta na valorização da brancura ${ }^{47}$ e se encontra balizada pelo "[...] prisma anti-negro, como meio de embranquecer a população de cor" (SANSONE, 2003, p. 286).

O mito da democracia racial e a contemplação da mestiçagem enaltecem a ideia de uma identidade nacional "mestiça", cujo efeito homogeneizador (ORTIZ, 1989) implicou no estabelecimento de um leque de terminologias de cor que dificulta o discernimento de fronteiras entre os diferentes grupos étnicos e, ao mesmo tempo, favorece a manutenção da hierarquia entre subgrupos (LEITE, 2000). Segundo Sansone (2003, p. 19), o sistema de relações raciais na sociedade brasileira, “[...] possibilitou aos indivíduos manipularem sua identidade racial e funcionou contra a mobilização [...]" do grupo étnico-racial negro, prejudicando o processo de afirmação da identidade negra. $\mathrm{O}$ autor ressalta que a maioria dos indivíduos em cujas certidões

\footnotetext{
47 A miscigenação pode ser manipulada e guardar, em sua essência, o ideal de branqueamento. Para Munanga (2015) e Sansone (2003), a problemática não está em si na mestiçagem, mas no modo como ela é utilizada. Munanga (2015) ressalta que a mestiçagem faz parte da história da humanidade e que o argumento de que há povos "puros", sem misturas, é um mito. Para Sansone (2003), a mestiçagem pode ter conotação antirracista quando não apresenta a "mistura" sob um prisma antinegro, pois pode contrapor a pureza racial, podendo, assim, ter uma função subversiva com relação a sistemas de dominação baseados na supremacia de alguns grupos em detrimentos de outros.
} 
de nascimento constam os termos pardo ou preto utiliza outros termos para se autodefinir, tais como moreno, escuro.

Em função da ideologia do branqueamento e desvalia histórica do elemento "negro", muitos tendem a não se autoidentificar, assim como muitos quilombolas não se autoidentificam da mesma maneira. No caso de Barro Preto, conforme revelam depoimentos apresentados no primeiro capítulo, há uma resistência de parte de seus moradores em se reconhecerem como pertencentes a uma comunidade quilombola, uma vez que faltam elementos de valorização positiva do que é ser negro. Segundo os relatos, essa recusa estaria associada à percepção de que "ser quilombola" implica em "ser negro", ou seja, ao assumirem-se como quilombolas, estariam simultaneamente assumindo uma ascendência negra.

Tal recusa pode ser explicada pela forma de tratamento humilhante à qual a população negra esteve submetida em tempos de escravidão e pode ser compreendida como uma tentativa de desvencilhamento de uma imagem social depreciativa. Segundo Mattos (2006, p. 111), “[...] dizer-se negro ainda é basicamente assumir a memória da escravidão inscrita na pele" sendo que “[...] a cor é a marca mais simbólica de um passado escravista”. Mas o que dizer daqueles moradores do quilombo que não carregam no corpo o estigma da cor?

Enquanto "patologia social", o racismo incide na subjetividade de negros e brancos, afetando a ambos, “[...] presos conjuntamente pelos mecanismos de 'raça' que alienam uns aos outros e amputam sua humanidade comum" (GILROY, 2007, p. 33) ${ }^{48}$. Nesse sentido, pode-se falar em "patologia do negro" e "patologia do branco", como defende Fanon (2008). Segundo o autor, a forma como o racismo afeta a subjetividade de negros e brancos é assimétrica, embora estejam igualmente inseridos em uma condição neurótica.

A subjetividade do negro seria marcada por uma ambiguidade neurótica, caracterizada pela alienação de si mesmo enquanto homem e assujeitamento ao mundo dos brancos, como efeito de um processo histórico complexo que orienta sua construção identitária. O branco, por sua vez, tem como marca de sua condição neurótica a crença em sua superioridade em relação ao negro. A ideologia dominante habita a todos, mas a branquitude ${ }^{49}$ induz a uma espécie de

\footnotetext{
${ }^{48}$ Em uma sociedade racista os corpos são descritos em função da ideia de "raça", alguns são racializados como inferiores e outros como superiores. Muito embora se tenha a comprovação cientifica de que biologicamente raça não existe, e que, portanto, não se pode dividir a humanidade em raças estanques, ainda prevalece no imaginário social a ideia de raça e os indivíduos se classificam segundo essa noção.

${ }^{49}$ Schucman (2012, p. 07), define branquitude como "[...] uma construção sócio-histórica produzida pela ideia falaciosa de superioridade racial branca, e que resulta, nas sociedades estruturadas pelo racismo, em uma posição em que os sujeitos identificados como brancos adquirem privilégios simbólicos e materiais em relação aos não brancos".
} 
"cegueira racial" "50, que, segundo Glass (2012), ao negar a ideia de raça, nega os privilégios garantidos pelo fato de "ser branco". O autor considera que, se por um lado, a premissa da raça não diz nada (moral, intelectual e socialmente) sobre uma pessoa e a cegueira racial se contrapõe à supremacia racial, por outro lado, ao propagar a raça como algo ruim - como se ser identificado racialmente fosse algo vergonhoso -, revela-se traços da própria supremacia racial, marcada pelo cinismo que nega que a ordem racial impregna a todos.

O branco não se vê ou não quer se assumir como parte de uma coletividade em que as conquistas individuais são devidas, em parte substancial, aos privilégios de seu grupo. A cegueira racial do branco não acontece simplesmente por ingenuidade, mas também por cinismo. Neste segundo caso, o sujeito esforça-se no sentido de corroborar e assegurar os privilégios simbólicos e materiais de seu grupo étnico-racial, negando o racismo e desresponsabilizando-se por sua manutenção.

Podemos dizer, emprestando termos psicanalíticos, que isso envolve uma negação de parte significativa da realidade, o que supõe alienação. Nesse tipo de funcionamento preconceituoso ocorre que o sujeito busca objetos sobre os quais pode projetar aquilo que é negado em si mesmo, como sua impotência e desamparo. Como ressalta Crochík (1996) - com base na discussão desenvolvida por Adorno e Horkheimer, a respeito da dicotomia forçafragilidade - é por isso que os objetos do preconceito são, em geral, considerados frágeis socialmente. Segundo o autor, "Dotamos o objeto do preconceito de características que devemos esquecer em nós mesmos. Assim, aquele que evoca a fragilidade, a natureza, deve ser perseguido para que a nossa força natural beire a onipotência” (CROCHÍK, 1996, p. 65). Ou seja, no caso do preconceito racial, o branco projeta no outro, o negro, o que não quer ver em si mesmo, como a inércia, o horror ao trabalho, a barbárie na desumanização do outro, a incapacidade de pensar.

Guerreiro Ramos (1957) traz importante contribuição acerca dos efeitos do racismo na subjetividade dos sujeitos brancos que evidenciam um outro tipo de negação, a da mestiçagem. Segundo o autor, essa patologia do "branco" brasileiro manifesta-se pela negação da ascendência miscigenada com negros em termos biológicos ou culturais. A recusa da ascendência miscigenada é evidenciada no relato de uma funcionária da escola, quando questionada sobre se os moradores brancos do bairro se identificavam como quilombolas.

Clarice (funcionária da escola): É raro... pode até acontecer, mas é raro. Outro dia ouvi de uma moradora dizer que não era quilombola, porque não tinha sangue negro preto, sua pele é branca, ela não gingava capoeira, não gostava de samba, não ia para

\footnotetext{
${ }^{50}$ Além da cegueira racial, Glass (2012) distingue mais quatro posições com relação à raça e ao racismo. São elas: supremacia racial, sensibilidade racial, crítica racial e antirracista.
} 
terreiro, e era do presente não do passado. Então acho que não é só não querer a cor na pele, é não admitir a cor no sangue.

Percebemos que o termo "cor" é utilizado para referir não somente à pele, mas à ascendência negra. Além de se revelar uma visão "biologizante" da questão racial, na fala o significante "negro" transcende as marcas corporais e a "cor" se revela como a principal marca do estigma na sociedade brasileira, abrangendo a cultura e as histórias africana e afro-brasileira.

Em discussão realizada a respeito das formas como o preconceito racial se manifesta, Nogueira (1954/2006, p. 292) propõe uma distinção entre "preconceito de marca", predominante na sociedade brasileira, em contraposição ao "preconceito de origem", característico da sociedade norte-americana:

Considera-se como preconceito racial uma disposição (ou atitude) desfavorável, culturalmente condicionada, em relação aos membros de uma população, aos quais se têm como estigmatizados, seja devido à aparência, seja devido a toda ou parte da ascendência étnica que se lhes atribui ou reconhece. Quando o preconceito de raça se exerce em relação à aparência, isto é, quando toma por pretexto para as suas manifestações, os traços físicos do indivíduo, a fisionomia, os gestos, os sotaques, dizse que é de marca; quando basta a suposição de que o indivíduo descende de certo grupo étnico, para que sofra as conseqüências do preconceito, diz-se que é de origem.

A diferença entre o preconceito de marca no Brasil e de origem EUA é discutido pelos alunos:

Oré: A gente é o segundo país que tem mais negros no mundo, né? Se não me engano. Dudu: O Brasil deve ser o país com maior quantidade de negros do mundo. Agora o continente africano tem mais, né? Mas o Brasil em termos de população é o maior, se não estou equivocado.

Muraguili: Não só de negros, né? De todas as culturas, de todas as etnias

Dudu: Tem uma foto que eu postei no facebook... É um turbilhão de cultura e etnia. Um turbilhão de tudo do mundo todo. Porque como é o caso da Europa... A Europa já tem a sua própria cultura, a Europa já tem assim... Como foi o caso de lá atrás aquela coisas dos assírios e dos fenícios eles já têm a formação deles, já têm os traços físicos, tudo próprio deles. Então, quando eles vieram procuraram aculturar o povo que estava aqui e os que trouxeram da África. Mas o Brasil não tem isso, o Brasil é a união, é um pouquinho dali, um pouquinho daqui, e um pouquinho de cá. Nós dois somos brasileiros porque nascemos em solo brasileiro, agora existem linhagens de vários povos aqui no Brasil. Aqui em Jequié mesmo, como é o caso, tem descendentes de negros, italianos, europeus, portugueses, é um misto muito grande.

Odara: Agora o Brasil é um país onde tem a maior quantidade de negros isso é óbvio, mas é um país eurocentrado, todo mundo quer ser branco, o raio branqueador é assim monstruoso.

Muraguili: É verdade, nessas diversas inscrições que eu faço mesmo de curso, eu pergunto: "Você se declara o que?" "Eu sou parda", "Eu sou branca", quando tem uma pessoa bem pretinha daí eu falo: "Você é preta" e ela fala: "Não eu não sou preta eu sou morena". Eu falo: "Gente você é preta, você não é morena, você é preta" Não bota aí preta não, porque eu não sou preta eu sou morena". Você vê já aquela coisa... Dudu: Da aceitação como é difícil.

Muraguili: É da aceitação da pessoa própria, assim... É horrível.

Oré: A gente estava discutindo isso em sala de aula... Quem foi que falou? ...Estava tu (aponta para Odara) e quem falou foi Lara não foi? Ela estava falando que ela se considerava negra e ela é da cor de Odara assim... um pouco mais moreninha. 
Odara: Mas tipo, é a versão do colorismo. Não sei se vocês já ouviram o colorismo!? O colorismo defende e fala que filho de negro independentemente da cor é negro.

Muraguili: Eu mesma me declaro negra.

Pesquisadora: Você é filha de negros Odara?

Odara: Não a minha mãe, mas a minha avó era negra.

Pesquisadora: E você se autoidentifica como?

Odara: Eu fico um pouco perdida. Porque às vezes eu falo: "Tá, eu me sinto negra". Mas eu fico assim: Se eu estou roubando a identidade de um negro e a pessoa não gosta, aí eu fico meio que perdida. "Você é parda". "Então, tá, eu sou parda". Porque a pessoa que tem a pele negra ela sente na pele o que é ser negra, e eu não sinto isso por ter a pele mais clara.

Muraguili: É verdade. Mesmo você vindo de linhagens de pessoas negras você não... Makbo: Mas o Brasil não olha a linhagem não, o Brasil olha a cor da pessoa mesmo. Nos Estados Unidos mesmo, eles olham a terceira geração se seu pai for negro e seu avô for negro... A pessoa pode ser branca, a pessoa bota lá se você precisar de alguma coisa... Lá você é negra. Lá você não pode desalinhar esse... essas gerações.

Podemos dizer que, para aqueles sujeitos brancos que tendem a negar sua ascendência negra, como no caso mencionado por Clarice, a "cor" da pele branca é utilizada como forma de acobertar uma origem, com receio de que esta, se revelada, os coloque em condição de desvalia? Em contraposição a esse caso, Odara, que tem a pele branca, afirma sua ascendência negra. Embora ela expresse sua vontade de se identificar como "negra", não o faz porque sabe que o corpo é um marcador importante na determinação da discriminação racial. Ou seja, ela reconhece o privilégio de sua cor. Sua vontade de se identificar como negra evidencia que ela tem identificações afetivas e culturais com o grupo étnico-racial negro. Não tem uma identidade marcada pelo corpo, mas uma identidade de solidariedade. A discussão do grupo, mais uma vez, realça a importância da cor, de maneira que o "ser negro" passa fundamentalmente pelo corpo, coincidindo com "ter sofrido preconceito".

Goffman (1985) assinala que quando o estigma é visível no corpo, a pessoa que o carrega fica em condição de desacreditado, enquanto que aquele que não o apresenta de forma visível está em condição de sujeito desacreditável, ou seja, se descoberto poderá colocar o indivíduo em condição de descrédito. Se utilizarmos a reflexão do autor sobre a condição do sujeito cujo estigma não está visível para compararmos a condição do sujeito branco de ascendência negra, veremos que ela não se aplica à sociedade brasileira. Como discutido pelos alunos, no Brasil ser branco não é estigma nem mesmo se sua ascendência for negra, nos Estados Unidos ser branco com ascendência negra é estigma.

Conforme argumenta Nogueira (1954/2006), onde prevalece o preconceito de marca, um indivíduo que possui traços "caucasoides" é considerado branco, ainda que se conheça sua ascendência ou parentalidade com pessoas negras, diferente dos Estados Unidos, onde independente do fenotípico, se a ascendência negra do indivíduo for conhecida ele será considerado negro, e, por conseguinte, será discriminado. Na sociedade estadunidense, o 
indivíduo de pele branca, de ascendência negra, pode fugir ao estigma desde que esteja em contexto em que sua ascendência não seja conhecida, enquanto no Brasil esse modelo de fuga do estigma não faz sentido. Contudo, no que tange à sociedade branca dos EUA, vale assinalar que se o sujeito é surpreendido fazendo-se passar por integrante do grupo social no qual não seria admitido, sofre profunda execração social. De modo geral, esse fenômeno, que ficou conhecido como passing, consistia em uma estratégia de integrações pessoal e social ao grupo dominante para evitar as consequências sociais do racismo, parte delas evidenciadas em políticas deliberadamente segregacionistas.

Retornando à fala de Clarice, percebemos que o imaginário da referida moradora revela o "preconceito de cor", ao sugerir uma relevância da cor de pele branca, em contraposição à “cor" de pele que revele o pertencimento étnico-racial à população negra. Há alusão à cor branca, como se esta fosse prova incontestável de uma "pureza racial”, ou seja, um sangue livre do elemento negro.

A hierarquização social baseada na cor de pele está presente no imaginário social, e opera em função da ideia de "raça" que aparece interligada à "cor". Assim, as inúmeras terminologias de cores são utilizadas como forma de se desvencilhar de um pertencimento à população negra e, consequentemente, de construções estereotipadas e estigmatizadas sobre o significante 'negro' e o 'corpo negro'. Ocorre uma espécie de racialização do significante 'negro' e do 'corpo negro', desprendida dos encaixes histórico, social e cultural, o que, na perspectiva de Hall (2003), culminou na transformação do 'negro', em uma categoria de essência (FERNANDES; SOUZA, 2016).

Nogueira (1998) salienta que, na rede de significações culturalmente construída, o ‘corpo negro' foi investido como tributário do indesejável, inaceitável, execrável, enquanto o ‘corpo branco' é relacionado a atributos morais e intelectuais positivos, identificado ao belo, puro e sagrado. Para a autora, isso ocorre, face à necessidade de estabelecer o modelo do que é desejável, a cultura define aquilo que é indesejável. O corpo negro e o corpo branco são racializados socialmente, inscritos como marca de identidade, passando a corresponder à perspectiva de uma identidade coletiva socialmente construída sobre o que é ser negro e o que é ser branco.

No que concerne à construção coletiva da identidade, recorremos à distinção proposta por Munanga (1996) entre identidade atribuída e identidade de autoatribuição. Enquanto a 
primeira abrange a seleção por um grupo de sinais diacríticos ${ }^{51}$ pertencentes a outro grupo para defini-lo, a segunda compreende a seleção destes sinais pelo próprio grupo para se autodefinir:

\begin{abstract}
Qualquer grupo humano, através de seu sistema axiológico, sempre selecionou alguns aspectos pertinentes de sua cultura para se definir em contraposição ao alheio. A definição de si (autodefinição) e a definição dos outros (identidade atribuída) tem funções conhecidas: a defesa da unidade do grupo, a proteção do território contra os inimigos externos, as manipulações ideológicas por interesses econômicos, políticos, psicológicos, etc. (MUNANGA, 2012, p. 24, itálico nosso).
\end{abstract}

Entendemos que identidade coletiva é uma categoria de definição de um grupo (MELUCCI, 2001) ${ }^{52}$, sendo “[...] algo que define fronteiras entre quem somos nós e quem são os outros" (SCHUCMAN, 2012, p. 40). Além disso, envolve uma compreensão do sujeito de acordo com a essencialização de seu grupo étnico-racial. No imaginário social, a identidade coletiva atribuída difere segundo o grupo étnico racial negro ou branco, mistificados socialmente de maneira contraposta. Enquanto o branco ganha status de superioridade, o negro torna-se paradigma de inferioridade, expressão do que é ruim ou exótico (FERNANDES e SOUZA, 2016). Os estereótipos forjados sobre o negro - representado como selvagem, estúpido, dócil - são produtos de um longo processo de fetichização implicado na construção social do "mito do negro" (FANON, 2008).

A identidade social atribuída ao negro é uma "identidade deteriorada" (GOFFMAN, 1985), baseada em estereótipos que influenciam relações e interações sociais. Atuando no processo de construção de representações sociais, essa identidade rotula e categoriza o negro, dificultando a criação de representações positivas sobre ele. Essa categorização funciona como forma de aprisionamento do negro a uma alteridade inventada e a um lugar de desacreditado que o impede de ser percebido em sua individualidade ${ }^{53}$. Nessa perspectiva, Moscovici (1978, p. 64) salienta que "[...] o racismo é o caso extremo em que cada pessoa é julgada, percebida, vivida, como representante de uma sequência de outras pessoas ou de uma coletividade”. Dessa forma, a construção da identidade pessoal pode ver-se subsumida à identidade social, que, no caso do negro, lhe impinge a marca do plural em detrimento da consideração de sua singularidade.

\footnotetext{
${ }^{51}$ Atributos pertencentes ao complexo cultural de determinado grupo, tais como religião, política, arte e visão de mundo.

${ }^{52}$ Para Melucci (2001), a identidade coletiva é algo compartilhado entre os sujeitos de uma coletividade, sendo sempre negociada e construída mediante as relações que estabelecem entre si.

${ }^{53}$ Id., 1978.
} 
É importante destacar que a singularidade da pessoa negra só é reconhecida em caráter excepcional quando ela alcança lugares sociais majoritariamente ocupados por brancos, o que é atribuído ao mérito pessoal, relacionado à sua capacidade particular. Essa situação é utilizada para reforçar o discurso da meritocracia, segundo o qual cada indivíduo pode, por esforço próprio, competir em condições de igualdade, discurso que serve, na realidade, para dissimular a desigualdade de condições e oportunidades. É como se as condições dadas a priori fossem as mesmas, isentando-se do reconhecimento da desigualdade relacionada à diferença de classe, raça, gênero. Nesse sentido, evita-se problematizar as situações de privilégio concreto ou simbólico do branco, as tratando como decorrentes de seu mérito. Inversamente, no caso da pessoa negra apresentar uma atitude socialmente reprovável, aqui o erro é visto como característico da coletividade negra.

Diferentemente, o sujeito branco "[...] quando comete algum equívoco é julgado como representante dele mesmo, e não pelo seu grupo. O negro é visto em bloco, é odiado ou tratado como coitado por representar a raça tida como reles, mas quando conquista algo, é tratado como exceção à regra" (COSTA, 2012, p. 217). Crochík (1996, p. 48) ressalta que essa generalização das características supostas de determinado grupo para todos os indivíduos que pertencem a ele é um dos elementos do preconceito: "A experiência individual, o contato com o particular, são obstados pelo preconceito".

A identidade social atribuída ao branco se alicerça em status de superioridade, que garante àqueles que correspondem a ela fenotipicamente, privilégios materiais e simbólicos em nível social (SCHUCMAN, 2012). No Brasil, a identidade branca se consolida no imaginário social como norma, influenciando na classificação racial dos sujeitos:

\footnotetext{
Normalizar significa eleger - arbitrariamente - uma identidade específica como o parâmetro em relação ao qual as outras identidades são avaliadas e hierarquizadas. [...] A identidade normal é 'natural', desejável, única. A força da identidade normal é tal que ela nem sequer é vista como uma identidade, mas simplesmente como a identidade. Paradoxalmente são as outras identidades que são marcadas como tais. (SILVA, 2000, p. 83, negrito do autor).
}

A identidade racial branca não é questionada, assim como não se questiona os privilégios daqueles que correspondem a ela, enquanto que as demais identidades são tidas como anormais e desviantes. Assim, os indivíduos tendem a ceder ao ideal de embranquecimento como tentativa de afastarem uma ancestralidade negra e se aproximarem de uma ascendência branca europeia.

Ainda com base no relato de Clarice, podemos inferir que a negação da ascendência negra não se relaciona apenas ao estigma associado à negritude e à escravidão, mas envolve 
também uma ideia "frigorificada" de quilombo (ALMEIDA, 2002). Trata-se de uma noção que compreende a formação de quilombo restrita à fuga de escravizados, desconsiderando outras formas de constituição (terras doadas, cedidas, de herança, entre outras), assim como o fato de que sua formação não se limitou ao período da vigência da escravidão. A multiplicidade de designações de quilombos - terra de parente; terra de mulheres; terra de pretos - revela o caráter plural de formação de quilombo, e evidencia não somente a especificidade inerente a cada uma dessas formações, mas demonstra que cada qual guarda " [...] uma especificidade complementar à outra, de modo a revelar a polissemia dos próprios conceitos sua realidade não fechada e comunicativa" (GUSMÃO, 1995, p. 132).

Leite (2000) assinala que a constituição do sujeito de direito "remanescente de quilombo" implica na superação de velhos estigmas e no reconhecimento do caráter heterogêneo dos grupos quilombolas, ou seja, das relações de consanguinidade entre os diferentes grupos étnico-raciais que compõe uma comunidade quilombola. $\mathrm{Na}$ sociedade brasileira foi difundida a falsa ideia de que a formação dos quilombos se restringiu ao período em que perdurou a escravidão, pois sua existência não teria mais sentido com a mudança do sistema de produção que não mais "escravizava".

Neste aspecto, o autor observa que a mudança corresponde à situação de existência dos quilombos, em que o “[...] caráter defensivo começa a mudar, em parte, com a Abolição, quando mudam-se os nomes e as táticas de expropriação, e a partir de então a situação dos grupos corresponde a outra dinâmica, a da territorialização étnica como modelo de convivência com os outros grupos na sociedade nacional" (LEITE, 2000, p. 338). O fato é que a invisibilidade social imposta aos quilombos fez com que prevalecesse no imaginário social a ideia de que eles já não existem mais, como se pode perceber na fala da moradora citada por Clarice.

Para Furtado, Pedroza e Alves (2014), o estigma da invisibilidade a que quilombo teve que se sujeitar para continuar existindo no passado é questionada pelos quilombolas, ao reivindicarem seus direitos na atualidade.

\footnotetext{
Os quilombos existentes ainda hoje no Brasil, configuram-se como tentativas de não absorção de uma identidade hegemônica. Assim como no passado colonial, a identidade quilombola se constrói, ainda atualmente, como uma identidade de luta e resistência: antes, contra a captura e a escravidão; hoje contra a invisibilidade e a negação da existência desses sujeitos enquanto quilombolas (FURTADO; PEDROZA; ALVES, 2014, p. 112).
}

A percepção negativa sobre "o ser quilombola" está associada à ideia estigmatizada de quilombo, como observa Dudu: 
término da escravidão, com a República ainda havia isso. E ainda hoje acontece. Mas se você reparar, que a escravidão foi abolida há que? Há 132 anos... mudou bastante, mas ainda a visão do quilombola...O povo fala assim: "Ah quilombola?" ...muitos não querem ser reconhecidos como tal, porque marginalizam até mesmo os quilombolas da comunidade. Então, esse processo de ressignificar a identidade é um processo lento...

Nesse contexto, a ressignificação de representações sociais sobre quilombo e o significante negro é imprescindível para a construção da identidade quilombola pois, no imaginário social, o quilombo representa o "grande negro", por ser depositário de todas as representações negativas sobre o "ser negro" na sociedade brasileira. Particularmente no caso de Barro Preto, a operatividade dessa representação negativa é evidenciada na fala de Pedro, quando menciona a dificuldade dos moradores em assumirem o rótulo jurídico "remanescente de quilombo".

[...] segundo o que muitas pessoas me falaram, outras pessoas estavam achando que isso era discriminação. Porque a população ainda não aderiu que isso aqui é quilombola. Acham que é uma discriminação sobre os negros, achando que eles são negros. "Acham que agora somos negros".

A fala revela uma associação negativa entre ser quilombola e ser negro, que pode ser evidenciada quando Pedro refere o episódio da escolha do nome da Associação do bairro, abordado anteriormente. O nome do bairro é depositário do termo "preto", tradicionalmente usado para se referir à cor do corpo negro, principal característica fenotípica utilizada para estigmatizar a população negra. Esse termo historicamente é tomado como adjetivo desqualificante, a exemplo da expressão "coisa de preto" para se referir a algo malfeito ou sujo, a uma atitude considerada inculta ou não civilizada. Se livrar do termo pode ser entendida como uma tentativa de se ver livre do estigma social, não somente relativo à cor negra, mas relativo ao bairro. Em contrapartida, a fala de Pedro, defendendo a importância de se manter o nome Barro Preto, é representativa de outro discurso vigente entre os moradores, um discurso em busca de ressignificação construída pelo grupo e não atribuída pelo outro.

Embora tenham conotações diferentes, os termos negro e preto ${ }^{54}$ são utilizados para se referir à pessoa negra, enquanto "[...] o primeiro se refere ao fenotípico negroide, e o segundo

\footnotetext{
${ }^{54}$ Guimarães (2008) oferece leitura interessante e resumida para entendermos as variações, apropriações e ressignificações dos termos negro e preto. Até o século XV, o termo negro teria sido utilizado, pelos portugueses, de maneira genérica para designar todos os povos de pele mais escura que a sua, enquanto o termo preto, anteriormente aplicado para designar os africanos subsaarianos, seria empregado para denominar os negros de pele mais escura (TINHORÃO, 1988 apud GUIMARÃES, 2008). No Brasil colônia, o termo negro foi utilizado no sentido de status social pelos portugueses para se referir aos escravos, incluindo os índios, que eram chamados "negros da terra" (MONTEIRO, 1994 apud GUIMARÃES, 2008). Na primeira metade do século XIX, o termo "negro" passou a ser utilizado para designar a cor, assim como o termo "pardo". Na metade desse mesmo século, na Bahia, o termo "preto" designava africanos, e "crioulo", negros nascidos no Brasil (CUNHA, 1985 apud
} 
à cor negra propriamente dita" (SANSONE, 2004, p. 73). No entanto, o entendimento e emprego desses termos varia de contexto para contexto, segundo Sansone (2004), que constata que o termo utilizado para se autoidentificar pode não estar relacionado somente à aparência física, mas ao estilo de vida, grau de instrução, à posição social, entre outros fatores. O autor menciona que pessoas negras de maior renda tendem a identificar-se como escuros, pardos ou morenos, enquanto que o termo preto é utilizado, majoritariamente, por pessoas negras mais pobres e que não veem perspectiva de mobilidade social, nem sempre mais escuras ou negroides que aquelas que se identificam como pardas.

Para o autor, “[...] ser de ascendência africana, pobre e até discriminado não basta, como tal, para que uma pessoa negra reivindique algum tipo de identidade negra." (SANSONE, 2004, p. 22). Por outro lado, jovens negros, que socialmente seriam vistos como pardos, utilizam politicamente a categoria preto para se identificarem como negros. Entendemos que este se trata de um processo de ressignificação do termo preto, tal qual identificamos no relato de Pedro.

Cabe ressaltar que o termo "negro" foi ressignificado pela população negra que, durante longo processo histórico, impulsionou a mobilização negra, engendrando diversas organizações com base na identidade racial e na inclusão social. A popularização do termo ocorreu a partir da ação política da Frente Negra Brasileira no início da década de 1930 (SANSONE, 2003). Mas foi especificamente com o Movimento Negro Unificado (MNU) (1978) ${ }^{55}$ que o termo passou a ter um sentido mais aglutinador e político. Como assinala, Domingues (2007, p. 115):

Para incentivar o negro a assumir sua condição racial, o MNU resolveu não só despojar o termo "negro" de sua conotação pejorativa, mas o adotou oficialmente para designar todos os descendentes de africanos escravizados no país. Assim, ele deixou de ser considerado ofensivo e passou a ser usado com orgulho pelos ativistas, o que

GUIMARÃES, 2008). Já em meados do século XIX, o termo “preto” abrange africanos e descendentes de africanos, enquanto "negro" paulatinamente deixa de ser termo utilizado para designar a "cor" passando a ser utilizado de modo racial e ainda mais pejorativo (REIS, 2000 apud GUIMAR ÃES, 2008). Nos anos que antecederam a abolição, o termo "negro" era utilizado com sentido pejorativo, enquanto "preto" ganha significado mais neutro (SCHWARTZ, 1987 apud GUIMARÃES, 2008). Guimarães (2008) assinala que, no período pósabolição, o termo "negro" continua com sentido pejorativo e ofensivo referindo-se a "escravos", enquanto "preto" se referia à "cor" e não à posição social. (Cf. TINHORÃO, J. R. Os negros em Portugal. Lisboa: Editorial Caminho, 1988; SCHWARTZ, L. M. Retrato em branco e negro: Jornais, escravos e cidadãos em São Paulo no final do século XIX. São Paulo: Companhia das letras, 1987; MONTEIRO, J. M. Negros da terra: índios e bandeirantes nas origens de São Paulo: Companhia das Letras, 1994; CASTRO, H. M. M. A cor inexistente: relações raciais e trabalho rural no Rio de Janeiro pós-escravidão. Estudos Afro-asiáticos, n. 28, 1995; REIS, J. J. De olho no canto: trabalho de rua na Bahia na véspera da Abolição. Afro-Ásia, n. 24, 2000).

${ }^{55}$ Domingues (2007), em artigo intitulado, Movimento Negro Brasileiro: alguns apontamentos históricos, faz uma análise sobre o Movimento Negro desde sua formação durante o período da República (1889) até o ano 2000. O autor divide a atuação do movimento em três fases. Segundo ele, o Movimento Negro Unificado (1978) teria sido fundado na terceira fase (1978-2000), etapa em que o protesto passa a ser mais contundente e superar abordagens assimilacionistas e conformistas presente em outras fases. Nesta etapa, segundo o autor, prevaleceu a proposta de unificação da luta de todos os setores oprimidos da sociedade e organizações antirracistas, com intuito de fortalecer politicamente o movimento negro. 
não acontecia tempos atrás. O termo "homem de cor", por sua vez, foi praticamente proscrito.

Para Sansone (2003), a popularização do termo negro não significa que a terminologia sobre a cor esteja rume para um patamar de polarização entre negros e brancos, pois novos significados sobre o termo surgem a cada nova geração. Atualmente, o termo negro se consolida como categoria sociopolítica de conotação positiva. No entanto, a polaridade branco/negro, na sociedade brasileira, ainda organiza o gradiente de cor e de status social (GUIMARÃES, 2000), assim como persistem no imaginário social estereótipos que estigmatizam o negro e que ainda cumprem a função de associá-lo à inferioridade e de delimitar lugares sociais sulbalternizados.

Cabe assinalar que a criação de significados, como propõe Hall (2006, p. 11) consiste, em parte, na tentativa de criar mundos fixos e estáveis. Entretanto, o significado "[...] é inerentemente instável: ele procura o fechamento (a identidade), mas ele é constantemente perturbado (pela diferença). Ele está constantemente escapulindo de nós”. Ou seja, dos significados atribuídos, novos surgem, independentemente de nossa expectativa ou, até mesmo, subvertendo-a. Além do significante "negro", outros termos como cultura negra, identidade negra, quilombo, identidade quilombola, entre outros, não têm conotações estáticas e específicas, são constructos sociais dinâmicos que ganham novos significados variando no tempo e espaço.

\subsection{Identidade quilombola: uma identidade étnica e racial}

Falar em identidade quilombola, pressupõe duas dimensões: étnica e racial. Cabe ressaltar que a identidade é entendida, aqui, como um processo inacabado que abrange aspectos pessoais, históricos e sociais e que compreende uma relação dialógica entre eu e o outro, entre pessoas e grupos sociais tendo, nessa medida, uma significação étnica. Considerar a dimensão étnica da identidade é reconhecer seu caráter coletivo de constituição e as complexidades que a envolvem.

Segundo Poutignat e Streiff-Fenart (1998), a identidade étnica se fundamenta na crença em uma origem comum e tem caráter processual, pois se constitui através de processos criados pelo grupo, que busca tecer uma continuidade com o passado. Para construir e manter fronteiras que o diferencie dos demais, o grupo tem de selecionar símbolos identitários, fazendo uso da sua memória histórica a fim de nomear acontecimentos fundadores de uma origem comum. Esta origem é recriada no tempo e no espaço, pressupondo “[...] que uma identidade étnica seja 
sempre de certo modo criada ou inventada [...], o que [...] não implica por isso que seja inautêntica ou que os autores que a reivindiquem possam ser taxados de má-fé" (POUTIGNAT; STREIFF-FENART, 1998, p. 165) A identidade étnica é, em parte, construída ficticiamente. Para os autores, esse passado recriado relaciona-se à memória coletiva e não a um tempo histórico propriamente dito.

No caso de Barro Preto, a origem da comunidade se relaciona a um grupo de garimpeiros negros. Há duas construções históricas apontados pelos sujeitos da pesquisa que servem para fazer a ligação com os primeiros habitantes do bairro: Abarracamento e Caixa d'água. Estas construções constituem recursos que permitem ao grupo tecer uma continuidade entre seus membros, por meio do reconhecimento e recriação de uma origem comum. No entanto, segundo Barth (1997), a etnicidade de um grupo não se define por aspectos culturais internos (valores, costumes, língua, religião, índices visuais), mas pelas fronteiras. Dessa forma, ainda que determinados aspectos culturais, como língua e religião, sejam objetivamente observáveis, não podem ser considerados atributos étnicos, a menos que sejam utilizados pelo grupo como marcadores de pertença. Uma parte significativa da comunidade Barro Preto parece hoje apoiarse nesses símbolos para recriar uma história comum entre os habitantes do presente e do passado.

As identidades étnicas são mutáveis, pois as fronteiras elaboradas pelo grupo podem sofrer transformações, na medida em que os atributos ("sinais diacríticos") selecionados para marcar oposição entre "eles" e "nós" são substituídos ou reinterpretados. Assim, a "[ ...] história comum pode ser puramente ficcional e invocada ou esquecida de acordo com as circunstâncias" (POUTIGNAT; STREIFF-FENART, 2003, p. 165). Barth (1997) alerta que, para identificar o que determina as definições e redefinições de fronteiras entre grupos, deve-se considerar as relações entre pessoas ou grupos, o modo como percebem as diferenças e a significação que lhes são atribuídas nas relações sociais. Deve-se, ainda, atentar para a maneira como as dicotomizações entre "eles" e "nós" são produzidas e mantidas e que efeito têm sobre o comportamento do grupo.

O conceito de "grupo étnico", conforme, ainda, o autor, possibilita o reconhecimento da autonomia que grupos remanescentes de quilombos têm sobre a construção de sua identidade. Ao invés de uma definição puramente antropológica e histórica baseada na descrição dos grupos, tem-se nesse autor uma análise que considera a especificidade do contexto e de aspectos subjetivos que envolvem a constituição da identidade do grupo, incluindo o modo como se percebe e se define em relação a outros grupos sociais. 
A identidade quilombola, como todas as etnicidades, é relacional, não surge espontaneamente, é algo construído, que envolve uma consciência de identidade atingida pela experiência de um sentimento que se constitui em ação, na participação do indivíduo na coletividade, no grupo, na comunidade (SANSONE, 2004). Dessa forma, no caso, a etnicidade agrega caráter mobilizador em termos de construção de identidade quilombola, correspondendo a um modo de organização e mobilização social dos sujeitos "remanescentes de quilombos" no presente. Como sugere Arruti (1997, p. 23), “[...] a adoção da identidade de remanescentes por uma determinada coletividade, ainda que possa fazer referência a uma realidade comprovável, é, com muito mais força, a produção dessa própria realidade [...]". O rótulo "remanescente de quilombo" seria uma etapa inicial do "realce" da identidade étnica, anterior à seleção de elementos para tipificar o grupo.

O domínio do realce de uma identidade étnica é delimitado pelas múltiplas fontes de estereótipos pelos quais os membros de uma sociedade definem as pessoas e as situações. Na medida em que numa sociedade pluralista, os indivíduos conhecem a existência e o conteúdo dos estereótipos que os outsiders têm sobre eles, orientam-se nesse mundo de estereótipos tentando afastar os realces que lhe são perigosos e promover aqueles que são vantajosos (POUTIGNAT; STREIFF-FENART, 1998, p. 169).

Como dito anteriormente, a maioria dos moradores da comunidade de Barro Preto está em fase de assimilação desse rótulo jurídico, pois há resistência em assumi-lo como denominação da comunidade. O realce da identidade do sujeito como "remanescente de quilombo" o torna identificável por um conjunto de estereótipos que expressam construções negativas associadas à negritude, como ignorância e marginalidade. No imaginário coletivo, a categoria "remanescente de quilombo" está associada às categorias negra e quilombola, ambas estigmatizadas por um mesmo repertório de rótulos e estereótipos socialmente atribuídos à população negra.

Nesse sentido, é importante salientar que o racismo nega aos sujeitos pertencentes à população negra o direito de auto atribuírem sua identidade, ao mesmo tempo que exerce um caráter formativo (ou de deformação) de nomeação levando-os a resistir à pertença a determinada coletividade. Como argumenta Cunha Junior (1998, p. 52) "As restrições sociais e de representação de que somos alvo dão um contorno de identidade ao grupo social [...] O racismo brasileiro utiliza o critério étnico para definir as possibilidades de representação dos afrodescendentes na sociedade".

Concordamos com a afirmação Cunha Junior (2007) de que "ser negro" não se resume à existência do racismo, sendo que o mesmo pode ser dito sobre "ser quilombola". Porém, falar em identidade negra e quilombola envolve, necessariamente, considerar as implicações do 
racismo na construção dessas identidades, tanto do ponto de vista individual quanto coletivo. É preciso, ainda, mencionar, no âmbito das culturas e das histórias africanas e afro-brasileiras, as deturpações que o racismo impingiu a essas identidades. Também seria impraticável abordar as condições de vida da população negra sem associá-las ao racismo, enquanto um dos mecanismos responsáveis pela produção e manutenção das desigualdades sociais nas esferas da economia, de poder e das relações sociais.

No caso de Barro Preto, a percepção social de seus moradores pelo restante da cidade explicita o estigma social que, de certa forma, os unifica em termos de oportunidades sociais, culturais e econômicas.

O Barro Preto sofre com todos os estereótipos e preconceitos construídos ao longo dos anos e sustentados pelas mídias. Os moradores são socialmente marginalizados. Não estão nos moldes "sociais" aceitáveis. A falta de fontes simbólicas positivas do povo negro contribui para uma baixa auto-estima [...] (Fonte: PPP/2012).

Assim, podemos entender que a identidade coletiva desse grupo quilombola está ligada à identidade negra atribuída socialmente, pois é justamente através das características físicas ligadas à sua ascendência negra, que prevalecem entre seus moradores, que a comunidade é estigmatizada.

Lima (2008) e Appiah (2010) oferecem elementos importantes para pensar a identidade negra e quilombola em termos étnico-raciais. Segundo Lima (2008), o conceito de raça é uma categoria historicamente implicada com a afrodescendência da população brasileira. Atualmente, sabemos que tanto "raça biológica" quanto "raça social" são construções socioculturais.

[...] a ciência demostrou que a raça biológica foi uma manipulação ideológica, eurocêntrica, com a finalidade de dominação, então raça biológica também foi socialmente construída, e a transição da categoria raça biológica para raça social não estabelece, por si só, suficiente autonomia dos conceitos, sendo preciso considerar também seus significados no contexto da produção científica e do imaginário social. (LIMA, 2008, p. 38).

Dessa forma, raça enquanto social permanece no imaginário coletivo e influencia o modo como as pessoas se relacionam e se classificam. Para Appiah (2010), não há como falar em racismo sem se haver com o conceito de raça, sobretudo porque ele desempenha um papel central na prática racista. $\mathrm{O}$ racismo atua como elemento que adscreve as identidades, ou seja, produz e aplica rótulo às pessoas. A construção da identidade se estabelece em um processo dialógico em que rótulos influenciam o modo como as pessoas concebem a si e aos outros. 
Nessa perspectiva, rótulos operam no processo de identificação ${ }^{56}$ “[...] através do qual um indivíduo intencionalmente constrói seus projetos de vida - incluindo seus planos para sua própria vida e sua concepção de bom - pela referência aos rótulos disponíveis, identidades disponíveis" (APPIAH, 2010, p. 130).

Ainda segundo o autor, em termos de raça, o corpo é o ponto principal utilizado para adscrever identidades, sobretudo no Brasil, em que prevalece o preconceito de marca. Nossa identidade constrói-se também em conformidade com a visão e os discursos que os outros têm e produzem sobre nós. Com base nestas reflexões, podemos entender que, na medida em que se estabelece um consenso sobre a adscrição de identidade racial a partir do corpo, o sentido da "escolha" da pessoa negra quanto à identidade racial adscrita (atribuída) ser ou não dela, se torna limitado. Dudu, por exemplo, nos lembra que é visto como negro, em qualquer lugar que frequente, por conta de seu corpo negro. Assim, sua identidade racial é formada pela personificação do corpo negro, o que conforma sua identificação com "ser negro" ainda que, em parte, essa identificação possa ser pensada como escolha, uma vez que ele pode voluntariamente organizar sua vida em torno dessa identidade.

A identidade quilombola não é uma identidade necessariamente adscrita através do corpo, pois no imaginário social ser quilombola é ser negro, mas ser negro não implica ser quilombola. Assim, dependendo do espaço frequentado, o quilombola, negro ou não negro, pode escapar a essa adscrição, uma vez que tem a opção de se identificar ou não perante o outro como tal. Dudu narra um caso em que é possível perceber a escolha, por parte de colegas, de não realçar o pertencimento à comunidade quilombola:

Dudu: Quando eu fazia cursinho lá no IERP era o Pronatec. Tinha certas pessoas da direção que tiravam sarro da gente porque atrás [da camiseta/uniforme escolar] tinha o nome "Quilombola". Eu falei: "Oh, menino está tirando sarro porquê?" E eles falavam: "Olha os quilombolas". Porque o povo fala do termo quilombola de uma forma pejorativa e muitos se sentiam incomodados, tiravam a farda [camiseta/uniforme escolar] e colocavam a farda do curso.

Pesquisadora: Meninos aqui do colégio?

Dudu: Isso aqui da escola. Porque as outras pessoas de lá usavam o termo quilombola como um termo pejorativo: "Ah seu quilombola, não sei o que", "Ah os quilombolas...". Um dia um chegou para mim e perguntou: "Vem cá, lá é como um quilombo mesmo?" Eu falei: “Como assim?”. "Lá é aquelas casas feitas de barro e tal?" Olhei para a cara dele assim e nem respondi, né? Olhei para a cara dele e acho que a minha expressão facial, o meu olhar, respondeu tudo. Olhei assim e sai.

\footnotetext{
${ }^{56}$ As identificações são construídas nas relações sociais, mediante as identificações e os posicionamentos dos indivíduos com relação aos discursos (FURTADO, M. B; SUCUPIRA, R. L.; ALVES, C. B., 2014). Quando internalizados pelos sujeitos os rótulos tendem a influenciar suas identificações e seus posicionamentos. Muitas pessoas negras, tendo em vista a internalização de rótulos negativos - que incutem a "[...] noção de 'inferioridade' do negro ou de indesejabilidade dos traços negroides [...]" (NOGUEIRA, 1954/2006, p. 296) - tendem à autonegação identitária. Daí a necessidade de contranarrativas, ou seja, de discursos, que apresentem referenciais positivos sobre o corpo, a história e a cultura negra, para que a pessoa negra tenha a opção positiva de identificação e de posicionamento com relação a sua origem étnico-racial.
} 
Pesquisadora: É aquela visão do quilombo antigo, né?

Dudu: Isso aquela visão estigmatizada.

$\mathrm{Na}$ interação social, em que estereótipos são ativados, os indivíduos conhecem sua existência e conteúdo, podendo orientar-se no sentido de afastá-los, o que explica a atitude dos meninos de retirar o uniforme da escola, cujo nome os associava à comunidade quilombola. Neste caso, a camiseta funcionou como elemento visível através do qual se pode adscrever uma identidade ao outro. Em contrapartida, se a identidade não pode ser adscrita pelo corpo, o indivíduo que deseja ser identificado como pertencente a determinado grupo étnico-racial pode utilizar elementos para marcar-se etnicamente, de maneira a levar os outros a adscreverem uma identidade para ele (APPIAH, 2010).

Compreendemos, portanto, que a identidade quilombola, assim como a identidade negra, comporta as dimensões étnica e racial. Ambas são interpretadas socialmente com o "script" negativo sobre o ser negro, a partir de narrativas que produzem imagens degradantes a respeito de seu corpo, sua história e cultura. Sendo assim, do ponto de vista étnico-racial, a identidade quilombola surge no imaginário social quase que indissociável da identidade negra. Lima (2008) relaciona o conceito de etnia aos aspectos de base material e imaterial produzidas pela população negra. A autora argumenta que:

[...] a articulação entre etnia/raça torna-se sócio-historicamente mais situado e abrangente e condizente com a multiplicidade identitária que compõe a população afro-brasileira deste país. Atende melhor aos propósitos devido ao maior distanciamento dos biologismos do passado, que ainda mantém seus resquícios no imaginário popular também se apresenta mais abrangente em acolher a diversidade de expressões das identidades negras e dos dispositivos de base africana que dinamicamente se expandiram no Brasil (LIMA, 2008, p. 39).

Para o autor, nas relações étnico-raciais, o enfoque étnico permite contemplar a multiplicidade de experiências, etnias e identidades negras reconstruídas a partir de repertórios culturais e históricos de matrizes africanas presentes na sociedade brasileira. $\mathrm{O}$ reconhecimento das referências ancestrais africanas na constituição das identidades pode auxiliar na desconstrução da visão monolítica de identidade. A autora salienta que a abordagem étnica favorece a criação de enfoques positivos com relação à história e às culturas africana e afrobrasileiras.

As identidades não podem ser mobilizadas independentememte do conteúdo cultural que lhes é associado, assim, o enfoque no caráter histórico e cultural do processo de construção identitária é fundamental para a desconstrução de rótulos sociais estigmatizantes. Dessa forma, para que uma comunidade quilombola possa assumir o rótulo jurídico "remanescente de 
quilombo" e construir sua identidade de autoatribuição, é necessário o que Poutignat e StreiffFenart (1998) denominam labelling étnico, que consiste em uma ressignificação pelo grupo do repertório caracterizado por um processo de rotulagem, pelo qual lhe é atribuído, a partir do exterior, uma identidade étnica.

[...] nas situações de dominação, frequentemente existem desníveis ou desacordos entre as identidades étnicas que os membros de um grupo se auto-atribuem e aquelas que os outros lhes conferem. O labelling étnico é então geralmente o objeto de uma relação de forças na qual o grupo étnico dominado tenta impor sua própria definição e desqualificar aquela que o grupo dominante pretende lhe impor (POUTIGNAT; STREIFF-FENART, 1998, p. 143, itálico dos autores).

Desconstruir o repertório de desqualificação é essencial para que moradores da comunidade de Barro Preto (negros e não-negros) possam superar preconceitos e desenvolver sentimento de pertencimento. No depoimento de Pedro, reconhecer-se como quilombola vai além do acionamento jurídico da categoria "remanescente de quilombo", enquanto estratégia para adquirir direitos, uma vez que envolve também a possibilidade de criação de um vínculo.

Pedro: Ser quilombola é residir em um bairro onde o Ministério da Cultura veio e comprovou que aqui é quilombola, entendeu? E para mim eu não tenho mania de dizer o branco e o preto, para mim todos somos iguais, o sangue que corre na veia do branco, corre na veia do preto, para mim é tudo comum, tudo normal... o que importa são os direitos, o sentimento de valorizar e formar a comunidade quilombola.

A fala de Pedro remete ao caráter coletivo da construção da comunidade quilombola e à importância da “[...] pertença étnica como categoria pertinente para a ação social e a crescente tendência de fazer derivar dela lealdades e direitos coletivos" (POUTIGNAT; STREIFFFENART, 1998, p. 26). A comunidade quilombola resultaria, então, da experiência compartilhada e da ação política. Conforme sugere O’Dwyer (2007, p. 46), a “[...] a afiliação étnica é tanto uma questão de origem comum como de orientação das ações coletivas no sentido de destinos compartilhados".

Durante a entrevista, foi possível perceber que Pedro considera que brancos e negros habitantes do quilombo possuem uma história em comum, mais especificamente ligada a um laço territorial da comunidade atual com os primeiros habitantes da comunidade de Barro Preto. Segundo Leite (2000), embora a terra seja uma base material importante para a manutenção das referências simbólicas, o compartilhamento de um mesmo território não é o elemento exclusivo de definição de um grupo, pois este se expressa pela dimensão relacional, ou seja, pela experiência solidária, mais do que pelo uso comum da terra. "Isto vem reafirmar que, mais do que uma exclusiva dependência da terra, o quilombo, neste sentido, faz da terra a metáfora para pensar o grupo e não o contrário" (LEITE, 200, p. 339). 
Em outras palavras:

[...] Quer dizer: a terra, base geográfica, está posta como condição de fixação, mas não como condição exclusiva para a existência do grupo. A terra é o que propicia condições de permanência, de continuidade das referências simbólicas importantes à consolidação do imaginário coletivo, e os grupos chegam por vezes a projetar nela sua existência, mas, inclusive, não têm com ela uma dependência exclusiva. Tanto é assim que temos hoje inúmeros exemplos de grupos que perderam a terra e insistem em manter-se como grupo, como o caso do Paiol de Telha, no Paraná (LEITE, 2000, p. 344-345).

Para a autora, a condição de membros do grupo é o que os identificaria como sujeitos do direito. O quilombo significaria, na atualidade, “[...] sobretudo um direito a ser reconhecido e não propriamente e apenas um passado a ser rememorado" ${ }^{\Perp 57}$. Essa concepção nos remete à fala de Pedro, anteriormente citada, na qual ele define quilombo: "quilombola é uma comunidade. Onde no passado tinha todos os direitos que tem hoje e ele não usufruía de nada e hoje o Ministério da Cultura está devolvendo tudo aquilo que foi negado a eles no passado”. Vemos que, de seu ponto de vista, os atuais moradores seriam herdeiros de direitos negados aos habitantes da comunidade no passado. Segundo o artigo $68^{\circ}$ do ADCT, a terra é um direito garantido aos "remanescentes de quilombos", que a estejam ocupando no presente, perspectiva na qual o passado é invocado e "[...] deve corresponder a uma forma atual de existência" (O' DWYER, 2002, p. 02).

Quando questionado sobre os critérios oficiais para ser considerado quilombola, Pedro coloca:

\footnotetext{
Essas regras não sabemos ainda. Mas, para mim (bate no peito), ser um quilombola é residir aqui há mais de dez anos. Não é chegou aqui com três anos e dizer "sou quilombola", só porque reside na comunidade. Ele reside sim numa comunidade quilombola, mas para ser quilombola, tem que ser nascido de dez anos atrás.
}

Afinal, deste ponto de vista, ser quilombola é residir na comunidade há mais de dez anos ou ter nascido nela há mais dez anos? Sua fala expressa a falta de definição vivenciada pelo grupo. Como estabelecer critérios precisos para definir o que é ser ou não quilombola, e pensar nos direitos a que esta definição se encontra atrelada? Essa ambiguidade é elucidativa do processo em construção pelos quais a comunidade passa, de pensar sobre sua identidade. No grupo com os alunos da escola, essa questão do ser ou não quilombola aparece na discussão a respeito das fronteiras da comunidade, em que a questão de sua demarcação geográfica é questionada - o que discutiremos mais adiante no texto.

Entendemos que, em meio à ambiguidade encontrada em sua fala, Pedro considera que para ser um quilombola não é necessariamente preciso ter nascido na comunidade (como é o

${ }^{57}$ Ibid., p. 335. 
seu caso), mas viver nela há um tempo suficiente para com ela ter estabelecido um laço de pertencimento.

O caráter permeável da fronteira étnica possibilita a mudança na identidade étnica e a assimilação de indivíduos "não-nativos". Em termos de etnicidade, é sempre possível a (re)criação de um parentesco fictício entre membros nativos e assimilados (POUTIGNAT; STREIFF-FENART, 1998). Assim como a etnicidade, o sentimento de pertencimento não é inerente ao fato de viver ou ter nascido na comunidade, pois trata-se de um processo contínuo que se relaciona ao desenvolvimento de um vínculo com os outros indivíduos pertencentes ao grupo. Esse vínculo não é inerente, mas um recurso a ser explorado:

De modo geral, importa reconhecer que qualquer que seja o grupo considerado, a questão de saber o que significa ser membro do grupo nunca se torna objeto de consenso, e que as definições de pertença estão sempre sujeitas a contestação e à redefinição por parte de segmentos diferentes do grupo. (POUTIGNAT; STREIFFFENART, 1998, p. 159).

No depoimento de Dudu, o pertencer à comunidade não aparece estritamente vinculado ao nascimento ou a um tempo determinado, mas a uma situação comum de exclusão social:

\begin{abstract}
O quilombola tinha isso, tinha aquela coisa de aderir. "Não, nos quilombos só moravam negros". Mas nos quilombos não moravam só negros, têm certos quilombos que não moravam só negros. Moravam indígenas, brancos marginalizados que eram expulsos da sociedade. Então, o quilombo tinha isso de família realmente de abraçar, de aceitação, de pegar "Olha nós também já passamos por isso. Você também passou? Vamos conosco". Então, vai se caracterizar principalmente nisso. O quilombo, como é colocado, é uma grande família, onde tudo ali era cultivado para todos, onde todos viviam em harmonia. Tinha hierarquia? Tinha. Mas o quilombo vai ser caracterizado por isso, que vai aderir as pessoas. Este negócio de estagnar, ficar ali estagnado: "Quilombo é só fulano, fulano, fulano" Eu acho errado. Eu acho errado porque vai tomar a identidade de outras pessoas. Dizer assim: "Não, você não participa não". Você vai negar a identidade de uma outra pessoa que.... Quando há fatores sociais... fatores sociais... errado eu acho é uma pessoa branca da elite vir aqui. "Ah eu sou quilombola". Até mesmo para usufruir das cotas. "Eu sou quilombola eu vou...”. Não, eu acho errado, porque daí quer tirar proveito da situação.
\end{abstract}

Dudu ressalta a composição heterogênea do quilombo relacionando-a a seu caráter agregador, característica apresentada na conceitualização de Munanga e Gomes (2004, p. 72) sobre os quilombos originários, segundo a qual o quilombo consistia em uma "[...] reunião fraterna e livre, com laços de solidariedade e convivência resultante do esforço dos negros escravizados em resgatar sua liberdade e dignidade [...]". Trata-se de uma definição tecida para se contrapor à ideia de quilombo como refúgio de escravos fugidos, difundida durante o século XVIII. Na fala de Dudu, o caráter agregador do quilombo é utilizado para tentar elaborar uma reflexão entre quilombo no presente e identidade quilombola. Para ele, não deve haver um julgamento estritamente jurídico de quem pertence, ou não, a determinado lugar e identidade, 
devendo-se levar em consideração o ponto de vista do próprio sujeito e o compartilhamento de uma mesma condição social de desigualdade.

No entanto, o "critério de assimilação" expresso por Dudu, de certa forma, fragiliza o conceito de "remanescente de quilombos", cuja ênfase recai sobre as especificidades das comunidades quilombolas com relação aos processos de resistência e sobrevivência, que remontam a uma memória de escravidão e territorialização, passível de ser reconstituída pelas redes de parentesco, afinidades, elementos históricos e culturais que configuram a malha do grupo (LEITE, 2000). A definição restrita de quilombo como lugar de excluídos, ou seja, como lugar que engloba indivíduos por sua condição comum dentro do sistema de produção, o torna esvaziado de sentido, na medida em que, entre outros aspectos, a identidade "remanescente de quilombos" é alternativa ao pertencimento de classe social.

Quando questionado sobre quais características julgava necessárias para ser quilombola da comunidade de Barro Preto, Dudu diz:

Assim não é só negro... porque já houve a mistura e tal. Mas a identidade, a cultura, que vai decidir isso. A cultura e também a história. Não só a cultura, mas você vai ter que observar de dois pontos. Vão estar assim intrínsecos, inerentes, que vai ser o fator histórico, o fator social e também o fator cultural, nisso aí. Vai ser uma mistura, uma trançazinha. Disso aí que eu acho que vai definir o que é quilombola.

Nas falas de Pedro e Dudu, o fenotípico não é ressaltado como elemento que poderia diferenciar o grupo quilombola de Barro Preto. Dudu utiliza-se do termo "mistura" referindose ao caráter miscigenado da comunidade, assinalando que o fenotípico negro não pode ser critério exclusivo para determinar quem faz parte da comunidade. Ele ressalta a importância dos aspectos históricos e culturais na decisão de quem é ou não membro do grupo. Lima (2008, p. 39) argumenta que a identidade tem um caráter histórico e cultural “[...] que demarca os conceitos de afrodescendência e etnia, imbricados na trajetória histórica dessa população [negra] em relação com outros grupos sociais".

\begin{abstract}
As identidades parecem invocar uma origem que reside em um passado Histórico com o qual elas continuam a manter uma certa correspondência. Elas têm a ver, entretanto, com a questão da utilização dos recursos da história, da linguagem e da cultura para a produção não daquilo que somos, mas daquilo no qual nos tornamos. Tem a ver não tanto com as questões 'quem nós somos' e 'de onde viemos', mas muito mais com as questões 'quem nós podemos nos tornar', 'como nós temos sido representados' e 'como essa representação afeta a forma como nós podemos representar a nós próprios' (HALL, 2000, p. 108-109).
\end{abstract}

Ser quilombola é algo que vai sendo (re)elaborado pelos sujeitos (SANTANA, 2008) e, como "ser negro", relaciona-se a um tornar-se, é "[...] preciso considerar como essa identidade se constrói no plano simbólico. Refiro-me aos valores, às crenças, aos rituais, aos mitos, à 
linguagem" (GOMES, 2002, p. 150). Ambas as identidades, negra e quilombola, possuem também uma dimensão política. Enquanto a dimensão simbólica diz respeito à construção de semelhanças e diferenças, a dimensão política é engendrada pela ação e experiência compartilhada.

Como tem sido pontuado com frequência, na comunidade quilombola de Barro Preto o preconceito em torno de uma origem negra compartilhada dificulta a adesão à designação "remanescente de quilombo". Isso indica, para fins de "autorreconhecimento", a necessidade de negros e não-negros habitantes desse território de identificarem-se com o grupo étnico-racial negro originário, reconhecendo nele sua ascendência. Essa identificação não pressupõe necessariamente identificar-se com elementos socialmente reconhecidos como pertencentes às culturas africana e afro-brasileira, mas os reconhecer e respeitar pelo seu valor histórico e agregador da comunidade.

Em termos de identificação, uma pessoa ou grupo não pode ser definido culturalmente ou receber determinadas características de pertencimento em virtude de sua identidade étnicoracial, pois "[...] nem todas as pessoas que podem ser definidas como negras num contexto específico partilham da cultura negra o tempo todo" (SANSONE, 2004, p. 23). Um erro a que se pode incorrer é atribuir uma identidade cultural aos indivíduos através de seu fenotípico. Não há uma cultura essencialmente negra ou quilombola, há elementos específicos que são partilhados de geração a geração, mas cada contexto compreende, se apropria e compartilha esses elementos de modo diferenciado, em um processo de construção e reconstrução. Existem culturas, identidades, histórias, etnias negras e quilombolas que guardam especificidades não engessadas no tempo e no espaço.

Ao contrário do que visões homogeneizadoras pronunciam, a identidade não é fixa, mas relaciona-se a um processo contínuo, em que as diferenças, como assinala Gilroy (2007), desafiam as coletividades racializadas. Esse processo envolve duas dimensões: individual (pessoal) e coletiva (intersecção das identidades coletivas). Construir a identidade coletiva não implica deixar a identidade pessoal em segundo plano, mas admitir que a dimensão coletiva é algo que também faz parte de nós. No viés político, a dimensão coletiva contempla as demandas e reivindicações por políticas públicas de reconhecimento social e combate às desigualdades sociais. Segundo Appiah (2010), para que um grupo chegue a narrativas de reivindicação de seus direitos tem que se haver, por um lado, com o combate às "velhas restrições" formuladas por discursos que elaboram um script negativo sobre ser negro e, por outro, com a promoção da ressignificação cultural desse script, recodificando-o. 
$\mathrm{O}$ autor ressalta que para prover outros modos de ser negro, este não deve reclamar o direito de ser respeitado, "embora" sua inscrição racial seja negra, mas de ser respeitado "como negro". Portanto, quando um indivíduo reivindica sua identidade negra ou quilombola está reivindicando a autonomia do seu eu, que em sua completude não pode ser definida por um rótulo. Rótulos não são dimensões pessoais do eu, pois esse não pode ser firmemente escrito pelo outro, nem constrangido por suas expectativas, mas (re)modelado pelo próprio sujeito em nível pessoal e coletivo.

A identificação como quilombola é uma escolha que pode ocorrer em um campo de significação política, a partir de uma construção coletiva que precisa contar com o que podemos chamar de "cumplicidade identitária", para que uma identidade coletiva seja autoatribuída pelo grupo. Isso não implica para um membro “[...] uma real atividade comunitária” (POUTIGNAT; STREIFF-FENART, 1998, p. 38), mas a crença subjetiva de que faz parte daquela coletividade, que apresenta características distintas de outras. "Esta ideia implica que não é o isolamento que cria a consciência de pertença, mas, ao contrário, a comunicação das diferenças das quais os indivíduos se apropriam para estabelecer fronteiras" $"$.

Essa crença subjetiva não alude a uma pertença racial, mas a uma pertença étnica, que se relaciona ao aspecto racial, mas não tem neste seu caráter fundamental. Com base na distinção realizada por Weber $(1971)^{59}$ entre pertença étnica e pertença racial, Poutignat e Streiff-Fenart (1998) apontam que a pertença racial é "realmente" fundada na comunidade de origem (parentesco biológico efetivo) e a pertença étnica envolve a crença subjetiva no vínculo na comunidade de origem (sentimento e representação coletiva).

Não pretendemos de modo algum buscar uma definição, uma verdade sobre o que é identidade negra e quilombola, pois isso seria o mesmo que desconsiderar seu caráter contínuo, dialógico e processual, mas colocar em evidencia as ambiguidades que envolvem a construção das identidades no contexto social. A identidade negra e quilombola expressa a necessidade de mudar o enfoque e ir além do combate ao racismo, pois a existência da população negra não se resume ao racismo, se estende a múltiplas formas de identificações, de produções culturais, políticas, históricas e sociais. Não consideramos raça ou etnia como conceitos únicos ou essenciais de explicação da existência e especificidades da população negra, mas como “categorias analíticas”(GUIMARÃES, 1998), que auxiliam na problematização e interpretação da produção social de diferenças sociais.

\footnotetext{
${ }^{58}$ Ibid., p. 40.

${ }^{59}$ Cf. WEBER, Max. Relations Communautaires Ethniques. In: Économie et Société, Paris, Plon, 1971.
} 
A identidade é um continuo, não se pode impor "normativas" (APPIAH, 2010) sobre ela, utilizando as categorias de raça ou etnia. As diferenças entre ser negro e ser quilombola precisam ser definidas com relação a contextos específicos, assim como histórias e culturas negras. Ser negro e ser quilombola são constructos sociais que se baseiam em uma pluralidade de fatores. Seja qual for o significado que os sujeitos confiram ao que é ser negro ou quilombola, importa reconhecer que esses sentidos são negociados interna e externamente. Pois, como assinala Sansone (2004, p. 25), “[...] o que é 'negro' para uma pessoa de fora não significa necessariamente a mesma coisa para quem está dentro do grupo, e vice-versa" - observação esta que também pode ser aplicada ao "ser quilombola".

Finalmente, vale ressaltar que é necessário deixar "[...] as argucias verbais sobre 'racialétnico' de lado e considerar simplesmente como as fronteiras são marcadas" (WALLMAN, $1978^{60}$ apud POUTIGNAT; STREIFF-FENART, 1998, p. 182), o que, no contexto de pesquisa estudado, envolve considerar os demais sentidos de ser quilombola.

${ }^{60}$ WALLMAN. The bounlaries of "race": processos of ethn city. In: England. Man, v.13, n2, 1978. 


\title{
4. IDENTIDADE QUILOMBOLA: UMA IDENTIDADE EM PROCESSO
}

Ao falarmos de identidade quilombola, é importante notar que seu desenrolar está associado ao termo jurídico "remanescente de quilombos", categoria criada a partir de uma denominação de quilombos historicamente reutilizada. A mesma não corresponde, pelo menos não originalmente, à designação utilizada por determinadas comunidades para se autoidentificarem, visto que ela foi criada através ato jurídico (Artigo 68 da Constituição Federal), que instituiu o remanescente de quilombos como sujeito de direito (ARRUTI, não datado). Segundo o autor, trata-se de uma categoria cujos termos "remanescente" e "quilombos" são aparentemente evidentes mas, de fato, obscuros.

\begin{abstract}
A Constituição fala em "remanescentes", tendo em vista uma outra noção, a de "quilombos", que por sua vez é caudatária de uma legislação repressiva de origem colonial, cuja eficácia dependia de sua generalidade e exterioridade com relação àqueles a quem se dirigia. No mais, o termo "quilombo" remete a um tipo de formação social e histórica que, a princípio, teria desaparecido com a própria escravidão e que se caracterizou justamente pela busca de invisibilidade frente ao Estado (ARRUTI, 2000, p. 115).
\end{abstract}

No entanto, o autor nos alerta que o termo "remanescente" introduz um diferencial com relação aos usos históricos e a outros presentes na Constituição Federal de 1988, trazendo uma nova visão do termo "quilombo", que deixa de ser visto como "reminiscência" de um passado, como uma "[...] continuidade concreta, material e direta com grupos históricos de negros fugidos”, para abranger as “[...] comunidades que se organizam para reivindicar esse laço” com o passado (ARRUTI, não datado, não paginado).

Pode-se dizer que o termo "remanescente de quilombo" impõe desafios ao entendimento da relação entre os diferentes grupos a serem contemplados por instrumentos jurídicos e as leis constitucionais, considerando que estas " [...] criaram realidades lá onde pretendiam apenas reconhecê-las, alterando situações de fato no plano local, ao mesmo tempo em que impondo novas questões aos seus ordenamentos jurídicos nacionais e ao campo acadêmico" (ARRUTI, 2000, p. 94). Nesse sentido, “[...] as perspectivas apenas começaram a ser delineadas e o próprio 'objeto' encontra-se em fase de definição, criando um espaço analítico ainda amorfo" (ARRUTI, 1997, p. 13).

O critério que prevalece para o reconhecimento de um grupo como "remanescente de quilombo" é o de autoatribuição pela identificação étnico-racial. No entanto, a forma jurídica de descrição deste desconsidera o caráter mutável da identidade quilombola. Como qualquer outra, a formação da identidade quilombola ocorre mediante um processo de construção e reconstrução pois, como assinala Hall (2006), as identidades não são cristalizadas no tempo. A 
identidade quilombola é uma identidade em processo, que se reconstitui e que se reconfigura ao longo do processo histórico; não é algo definido e estático, ao contrário, é dinâmico e constantemente transformado por elementos internos e externos ao grupo. Nessa perspectiva:

\begin{abstract}
A atenção na autoatribuição, nas fronteiras interétnicas, na contrastividade ou menos na situalidade identitária não dá conta da passagem entre o fenômeno de adscrição étnica (necessariamente local) do grupo (o etnômino) e a sua adesão a categoria genérica e englobante de indígena (ou de quilombola), de caráter jurídico administrativo. (ARRUTI, 2006, p. 40)
\end{abstract}

A autoatribuição não deve ser considerada fim último do processo de reconhecimento de um grupo étnico, pois o tornar-se quilombola é um processo dinâmico que não ocorre simplesmente pela adesão a um rótulo jurídico. Dessa forma, a identidade do grupo deve ser concebida como ligada ao movimento de autoconstituição do grupo (enquanto social e cultural) associado às transformações decorrentes do processo de atribuição de direitos, o que, portanto, vai além da referência à descoberta dos mesmos.

Concordamos com Arruti (1997; 2001), que considera que grupos quilombolas, além de remanescentes, devem ser pensados como emergentes, pois as fronteiras podem ser criadas e modificadas pelo próprio grupo, não podendo ser fixadas e delimitadas por rótulos jurídicos.

A importância de percebê-los como emergentes está em reconhecer que o seu lugar, porque ainda mal definido tanto com relação às condições de acesso aos seus novos direitos, quanto às condições de exercício de sua nova identidade, antes de fazer aqueles que o ocupam, ainda está por ser feito por aqueles que conseguirem ocupá-lo (ARRUTI, 1997, p. 30, itálico do autor).

A problemática levantada por Arruti (1997), a respeito das barreiras fixadas pelo rótulo jurídico, aparece na fala de um dos alunos participantes da pesquisa, Dudu, que expõe sua crítica ao caráter homogeneizador dos critérios de demarcação. Tais critérios delimitam fronteiras físicas sem abranger o caráter dinâmico e o fluxo da identidade quilombola, na medida em que reconhecem como pertencentes à comunidade apenas os habitantes da área demarcada como quilombo, limitando a eles o direito à autoidentificação.

Dudu: [...] Esses dias eu estava pensando comigo mesmo, né? Estava lendo sobre os quilombolas, indígenas... estas questões do Brasil, de demarcação. Aí, eu fui ler e tal quando Catarina naquele projeto aprovou aqui [refere-se às informações presentes no blog da escola sobre o reconhecimento do bairro como comunidade quilombola], colocou como sendo quilombola e a região como quilombola. E eu vi a descrição, algumas ruas apenas são...[...] E eu estava lendo mais sobre isso... Então, algumas ruas à margem da linha foram escolhidas agora como quilombola. Só que esta questão da cultura quilombola e de pertencimento vai transpor as barreiras físicas, já atravessou há muito tempo as barreiras físicas. Então, eu acho até de certa forma injusto você estar negando a identidade de uma pessoa dizendo assim: "Ah você mora aqui é quilombola" "Ah você não é quilombola não, tu não mora em tal rua". Eu acho que, de certa forma, isso está [...] está tomando, dizendo assim: "Você não tem o direito de pertencer essa identidade, você não tem direito de ter essa identidade". Eu acho que a identidade quilombola ela vai atravessar as barreiras físicas. Porque as famílias 
quilombolas de origem não ficaram morando só ali, se espalharam logo. Foram se espalhando, se espalhando... Hoje tem gente no bairro que não teve essa formação e nem sabe o que é isso? Tem. Mas tem aqueles que estavam presentes aqui, naquela época de viver na beira do rio, de ir lavar roupa na beira do rio, de pegar lata d'água na cabeça, de catar até ossos. Como foi o caso aqui... quando a gente passou aqui, depois que começou a construção da ferrovia agora. Vai fazer o que? Ficou ali na marginal da ferrovia, então isso começou a se espalhar. Até história que seus tios contam, que outras pessoas contam, que sua avó conta, coincide, fala da cultura, fala assim.... conta e em algum momento isso vai unir. [...] Então, como a cultura quilombola, a identidade quilombola ela vai atravessar... tipo assim, ela cresceu tanto naquela... nesse parâmetro que deu a ela, que ela transbordou, hoje ela já passou essas barreiras.

O relato de Dudu traz elementos importantes para reflexão acerca da identidade quilombola, assim como da categoria "remanescente de quilombo", pondo em evidência o fato de que a interpretação do sujeito a respeito pode ser diferente da interpretação jurídica. Ele evidencia o sofrimento envolvido no não reconhecimento da identidade do outro, concebendo que não se trata apenas da negação do direito de acesso, mas do direito de "ser", da experiência subjetiva de "pertencer" ao grupo. Sua fala evidencia que escolher quem faz ou não parte do grupo é uma decisão dolorosa. Conforme assinala Glass (2012), as lutas de um grupo para estabelecer suas próprias normas de inclusão são tão dolorosas quanto aquelas realizadas para resistir às definições externas impostas e se autodeterminar.

A afirmação da identidade e a marcação da diferença implicam, sempre, as operações de incluir e de excluir. Como vimos, dizer o que somos significa também dizer o que não somos. A identidade e a diferença se traduzem, assim em declarações sobre quem pertence e sobre quem não pertence, sobre quem está incluído e quem está excluído. Afirmar identidades significa demarcar fronteiras, significa fazer distinções entre o que fica dentro e o que fica fora. (SILVA, 2000, p. 82).

Nessa perspectiva, ao refletirmos sobre a realidade desses grupos emergentes, vale assumir o alerta de Arruti (não datado) de manter uma distância crítica em relação à categoria "remanescente de quilombos", para que não sejamos levados por uma tendência à fixação conceitual e ao descarte do seu caráter construtivista, aberto e criativo. Segundo Arruti (2001), a realidade permite desconstruir, reconstruir analiticamente e alargar na prática nossa ideia de quilombo, de remanescente e de identidade quilombola, num movimento em que os próprios rótulos jurídicos tendem à plasticidade, assim como as identidades que procuram abarcar. Tais rótulos são transformados pela realidade desses grupos, ao mesmo tempo em que a transforma, pois “[...] o que encontramos a partir de situações documentadas não são simples adaptações de memórias e identidades aos critérios estabelecidos pelo Estado, mas também uma adaptação das definições legais iniciais, sua multiplicação ou reinterpretação" (ARRUTI, não datado, não paginado). 
Por meio do depoimento de Dudu, vê-se ressaltada a importância do reconhecimento da identidade quilombola como uma identidade coletiva, marcada pelo caráter da plasticidade e atravessada por mudanças em concepções culturais e históricas no interior da comunidade. Há um movimento - atravessado por fluxos de cultura, interações e mediações - que denota o caráter fluido das fronteiras quilombo/não-quilombo, quilombola/não-quilombola:

As fronteiras entre quem é e quem não é da comunidade, quase sempre muito porosas, passam a ganhar rigidez e novos critérios de distinção, genealogias e parentescos horizontais passam a ser recuperados como formas de comprovação da inclusão ou não de indivíduos na coletividade (ARRUTI, 1997, p. 23).

\subsection{Identidade e memória}

A memória também aparece no depoimento referido como elemento central na construção da identidade quilombola. Em sua narrativa, os elementos cultural e histórico surgem interligados como aspectos importantes no alargamento dessa identidade que, por conseguinte, encontra na memória compartilhada sua fundamentação:

Dudu: Até história que seus tios contam, que outras pessoas contam, que sua avó conta, coincidi, fala da cultura, fala assim... conta, e em algum momento isso vai unir. [...] Então, como a cultura quilombola, a identidade quilombola ela vai atravessar... tipo assim, ela cresceu tanto naquela... nesse parâmetro que deu a ela, que ela transbordou, hoje ela já passou essas barreiras.

A cultura e a identidade quilombola aparecem nesta fala como construções coletivas que se relacionam às experiências social e individual de cada pessoa do grupo de maneira singular, mas, de alguma forma, coincidem, revelando repertórios comuns - ao que Furtado, Pedrosa e Alves (2014) chamam de conteúdos simbólicos-afetivos. Segundo as autoras, esses conteúdos, construídos e significados socialmente, emergem para cada indivíduo de acordo com sua experiência singular. Assim, a cultura quilombola pode ser definida como "[...] uma instância que preserva elementos culturais carregados de um passado histórico e social e que propicia um posicionamento subjetivo do sujeito ao reconhecer-se nesse passado" (FURTADO; PEDROZA; ALVES, 2014, p. 113):

[...] a subjetividade é produzida de forma simultânea no nível individual e social, com o reconhecimento da gênese histórico-social no momento de sua produção. Assim, ao considerarmos a subjetividade dos quilombolas, devemos compreendê-la não somente associada às experiências atuais do sujeito, mas como adquirindo sentido e significação dentro da constituição subjetiva da história do agente de significação. Ou seja, adquire sentido ao longo da história e por meio da transmissão de conteúdos, de forma simbólica e ao longo de gerações, por relatos de feitos heroicos, lutas, músicas, dentre outros. Os sujeitos, no caso, os quilombolas, ao denominarem-se como um grupo, e ao se reconhecerem como tal, compartilham valores, crenças e, acima de tudo, uma identidade com outros indivíduos, constituindo-se e reconhecendo-se como tal, simultaneamente. 
Esses conteúdos simbólicos formulados no contexto histórico-cultural se relacionam à continuidade com o passado e às particularidades do contexto vivido no presente. As autoras definem a cultura quilombola como instância que preserva esses conteúdos simbólicos, os quais são resgatados, vividos e transmitidos, possibilitando a construção subjetiva de um sentimento de singularidade e, ao mesmo tempo, o sentimento de pertença a um grupo com consequente compartilhamento de identidade comum. A identidade é erigida através de [...] "referência histórica comum, construída a partir de vivências e valores partilhados" (ABA, 1994). Contudo, essa referência a uma origem comum não se orienta pela noção de passado, segundo a ciência histórica, mas está representada pela memória coletiva" (POUTIGNAT; STREIFF-FENART, 1998, p. 13). O passado é presentificado através da memória coletiva, a qual não corresponde a um tempo histórico propriamente dito, devendo ser entendida como um processo (ARRUTI, 2006).

A memória coletiva é anunciada no depoimento de Dudu, quando se refere às histórias transmitidas pelos familiares de pessoas da comunidade. Cada narrativa individual sobre o passado oferece lembranças que subsistem, elementos que possibilitam a confirmação da origem comum do grupo e a reelaboração dessa memória coletiva. Em sua obra, Memória coletiva, escrita em 1950, Halbwachs (1990) ${ }^{61}$ argumenta que um grupo reencontra a imagem do seu passado por meio da história vivida. $\mathrm{O}$ autor assinala que a memória coletiva atua diretamente sobre a vida e o pensamento dos membros de um grupo, que estão ligados por lembranças em comum que lhes são particulares. Para esse autor, a memória individual tem fundamentação na memória coletiva, posto que é construída a partir das lembranças contidas no grupo social ao qual o indivíduo pertence.

Conforme pontuações de Pollak (1989; 1992) e Halbwachs (1990), compreendemos que o processo de construção da memória coletiva envolve negociação, reconhecimento e conciliação. Há conciliação entre memória individual e memória coletiva, afinal tem de haver concordância entre os testemunhos dos integrantes do grupo para que determinado aspecto ou fato possa ser reconhecido como elemento integrante da memória coletiva, o que implica em negociação e reconhecimento:

\footnotetext{
${ }^{61} \mathrm{O}$ conceito de "Memória coletiva" foi criado por Halbwachs pela sua importância ao funcionamento da vida social, tendo a função de estabelecer laços e permitindo comprovar que a sociedade funciona graças à existência de substratos comuns e de consensos entre os indivíduos. Trata-se de um conceito complexo e, posteriormente à sua elaboração, houve uma série de biografias dedicadas ao seu estudo. Há, atualmente, uma vasta bibliografia, assim como inúmeras pesquisas e novas abordagens sobre o conceito.
} 
Para que nossa memória se auxilie com a dos outros, não basta que eles nos tragam seus depoimentos: é necessário ainda que ela não tenha cessado de concordar com suas memórias e que haja bastante pontos de contato entre uma e as outras para que a lembrança que nos recordam possa ser reconstruída sobre um fundamento comum. Não é suficiente reconstituir peça por peça a imagem de um acontecimento do passado para se obter uma lembrança. É necessário que esta reconstrução se opere a partir de dados ou de noções comuns que se encontram tanto no nosso espírito como no dos outros [...]Somente assim podemos compreender que uma lembrança possa ser ao mesmo tempo reconhecida e reconstruída [...] (HALBWACHS, 1990, p. 34).

Ao ressaltar o papel do encontro e compartilhamento de histórias no processo de (re)construção da memória coletiva, o autor acima citado traz à tona uma dimensão territorial fundamental neste processo, proporcionada pelo viver de diversos sujeitos como membros de um mesmo grupo.

Quanto ao papel da negociação na construção da memória coletiva, segundo Pollak (1989), pode sofrer flutuações, dependendo do contexto em que a mesma é articulada e expressa, por isso não precisa ser compreendida de forma essencializada, ou seja, como forma fixa de definição de uma pessoa ou um grupo. Consideramos que a memória pode ser evocada a qualquer momento e, por isso, é sempre atualizada pelos sujeitos. No entanto, embora haja flutuações e transformações, há algo que permanece invariável no tempo. Assim como as identidades, as memórias não se liquefazem de modo a não se evidenciarem nelas permanências. Para Pollak (1992, p. 201), nas memórias individuais ou coletivas “[...] existem marcos ou pontos relativamente invariantes, imutáveis", “elementos irredutíveis”, os quais “[...] passam a fazer parte da essência da pessoa, muito embora outros acontecimentos e fatos possam se modificar $[\ldots] "$.

A plasticidade faz com que o grupo se abra a novas possibilidades, se reinventando e recriando uma memória coletiva, o que permite sua mobilização em torno de interesses e desejos compartilhados. Nesse sentido, a plasticidade é um elemento importante para a formação da memória coletiva de grupos que se autorreconhecem como quilombolas.

\footnotetext{
A "plasticidade identitária" formadora desses grupos permite, efetivamente, que eles "resgatem", "recuperem", elementos substantivos de identidade que passam a integrar seus processos de emergência, mas como "matérias-primas" que precisam ser manufaturadas pelas forças mobilizadas no seu interior, na forma de desejos coletivos (ARRUTI, 1997, p. 26).
}

O processo de identificação do grupo é indissociável da memória, pois a afirmação da identidade requer esforço em construir uma memória coletiva ${ }^{62}$, a partir da "[...] inevitável dispersão das memórias familiares, dos laços genealógicos, das imagens de si e dos exemplos

\footnotetext{
${ }^{62}$ Para Halbwachs (1990), a memória histórica compreende o que é aprendido e a memória coletiva, o que é vivido.
} 
de outras comunidades" (ARRUTI, não datado, não paginado). A memória familiar da escravidão se evidencia na fala de Dudu, ao relembrar narrativas familiares:

\begin{abstract}
Então, essa coisa assim da comunidade antes, olhando fotos assim tal.... Ela [avó] tem 51 anos...É que quando foi fundada aqui era uma escola rural, entre aspas, porque não tinha muitas casas ao redor e tal... Minha avó sempre... ela contava história e minha mãe passava assim, né? Não sei se passou da forma real porque com o tempo a memória se perde, né? Ela falava que a minha avó contava que a bisavó dela era escrava liberta, que criança ainda... foi liberta um tempo depois, porque ela escolheu morar lá, ela recebeu a liberdade e escolheu morar. Agora, de onde ela veio é que eu não sei exatamente, porque isso foi perdido com o tempo. A minha avó não era... devido ao que ela passou por muito tempo, ela não era muito de se abrir com a família para contar o que havia acontecido antes, aquela coisa assim de história.
\end{abstract}

Dudu ressalta que a "memória se perde”, mas ele mesmo é um lugar vivo e meio de sua transmissão. Sua narrativa revela o caráter vívido e contínuo da memória e sua capacidade de atualização mediante as lembranças transmitidas de uma geração a outra. Como afirma Nora (1984/1993, p. 09):

[...] a memória é a vida, sempre carregada por grupos vivos e, nesse sentido, ela está em permanente evolução, aberta à dialética da lembrança e do esquecimento, inconsciente de suas deformações sucessivas, vulnerável a todos os usos e manipulações, suscetível de longas latências e de repentinas revitalizações.

Nota-se que, na tentativa de descrever aspectos relacionados à comunidade, Dudu recorre a elementos históricos que se entrelaçam com a história de vida da sua família, que habita a comunidade de Barro Preto desde sua formação. Fica evidenciado que a reconstrução da memória no presente encontra como uma das principais barreiras um silenciar que nem sempre se faz pelo esquecimento.

Ainda que dinâmicas, as identidades mantêm continuidade com o passado histórico, por isso os saberes transmitidos entre as gerações são estratégias discursivas importantes. No caso de grupos quilombolas, mesmo que a identidade não tenha necessariamente uma origem concernente ao período escravocrata, possui com este uma intensa relação, que não pode ser negada (MATTOS, 2006). Entretanto, o processo de identificação leva os sujeitos do grupo ao encontro com um passado escravista doloroso que pode, consequentemente, refletir em omissão na narrativa de fatos do passado ou em esquecimentos acerca deles. Como o próprio Dudu apreende, esse pode ter sido o motivo de sua avó ser reclusa em suas narrativas.

A ausência da memória genealógica da escravidão na maioria das famílias negras brasileiras e os silêncios voluntários, relatados por muitos daqueles que se referiam diretamente a um antepassado escravo, possui um significado óbvio que não pode ser negligenciado: evidenciam a dificuldade em se construir uma identidade socialmente positiva com base na vivencia da escravidão (MATTOS, 2005, p. 54). 
Para Mattos (2006), as designações hierarquizantes, presentes na sociedade brasileira com relação à cultura e à história da população negra e, sobretudo, com relação à cor, ainda hoje fazem com que o recurso ao silêncio seja uma das formas mais usuais de se conviver com desqualificações. Por outro lado, segundo a autora, o rompimento com o silêncio se expressa na luta de grupos quilombolas que buscam reverter tal processo de hierarquização cristalizado no tempo quando reivindicam, como descendentes de escravos, políticas de reparação do Estado brasileiro. Dessa forma, ressalta-se "[...] o caráter político da memória, o fato de que sua recuperação coincide com a entrada em cena pública desses portadores de memórias marginalizadas, que trazem em seu bojo críticas, perspectivas, reinvindicações e valores que redefinem sua identidade [...]" (SOUZA, 1997, p. 285).

Pollak (1989) denomina de "memórias subterrâneas" aquelas que se referem aos grupos marginalizados e que se opõem à "memória oficial". Para o autor, essas memórias são subversivas, pois promovem uma subversão silenciosa ao atribuírem importância às "histórias subterrâneas". Segundo o autor, ao forjarem a história oficial, os opressores e algozes conduziram as vítimas ao silêncio e à renegação de si mesmas. No Brasil, a "memória oficial" representa os feitos e valores de um determinado grupo, ao mesmo tempo em que omite, marginaliza, distorce e inferioriza aqueles que caracterizam outros grupos, entre eles o grupo negro.

Essa memória limita a representação do grupo negro à escravidão, posicionando-o de forma passiva e bestial, ao mesmo tempo em que desconsidera aspectos importantes desse período histórico, escamoteando a trajetória desse grupo, sua ação protagonista na história, seu posicionamento, suas resistências, culturas e contribuições. Há um esforço em apagar a memória africana sobre a escravidão com intuito de definir um lugar subalterno à população negra e impossibilitar espaços para construções de contranarrativas ou contramemórias ${ }^{63}$.

A memória coletiva de grupos quilombolas evidencia aspectos escondidos da escravidão no Brasil, assim como demostra sua resistência contínua e histórica até os dias atuais, na luta pelo reconhecimento de seus direitos e identidades. Essas memórias dão visibilidade à existência do que Nora (1984/1993, p. 18) considera ser “[...] uma rede articulada dessas identidades diferentes, uma organização inconsciente da memória coletiva que nos cabe tornar consciente de si mesma”.

\footnotetext{
${ }^{63}$ O livro Diáspora negra e lugares de memória: a história oculta das propriedades voltadas para o tráfico clandestino de escravos no Brasil Imperial, apresenta uma abordagem do tráfico clandestino de africanos para o Brasil através da ótica de comunidades negras quilombolas, a partir de memórias que seus habitantes mantêm sobre esse passado.
} 
O processo de autoidentificação quilombola ocorre por meio da memória coletiva, pois a partir dele é que se torna possível tecer uma continuidade com o passado. Embora os grupos quilombolas não se caracterizem como reminiscência do passado, sua identidade é construída também mediante a uma reconstrução dele no presente. Segundo Silva (2012, p. 04) “[...] essa reconstrução está impregnada da leitura simbólica com categorias do presente, mais genericamente do que os [...]" membros são hoje. Assim, faz parte do processo de constituição da identidade quilombola aprender através da comunicação entre gerações, de suas memórias e diferenças históricas - aprendizagem que se inicia a partir do questionamento desse passado.

[...] é justamente essa a necessidade das gerações que se sucedem: formular novas perguntas ao passado, encontrar novas áreas de simpatia na medida em que revivem distintos aspectos das experiências de suas predecessoras. Se o passado não muda, a história, ao contrário, é feita sempre no presente e para o presente, provocada pela paisagem, condicionada pela prática social. (ARRUTI, 2006, p. 193)

Torna-se necessário elucidar as "memórias subterrâneas", recriá-las no presente, para que se possa reconstruí-las histórica e culturalmente, a fim de promover a transformação do imaginário e das representações negativas associadas a ser negro e ser quilombola.

\footnotetext{
Independente de "como de fato foi" no passado, os laços das comunidades atuais com grupos do passado precisam ser produzidos hoje, através da seleção e recriação de elementos da memória, de traços culturais que sirvam como os "sinais externos" reconhecidos pelos mediadores e o órgão que tem a autoridade de nomeação. As diferenças que podiam até então distingui-los da população local na forma de estigmas passam a ganhar positividade, e os próprios termos "negro" ou "preto", muitas vezes recusados até pouco tempo antes da adoção da identidade de remanescentes, passam a ser adotados (ARRUTI, 1997, p. 23, itálico do autor).
}

Esses "elementos da memória" podem ser acessados através da memória dos "mais velhos", as quais exercem uma função social, por impulsionarem um agir, no presente, por parte de outros membros do grupo (Silva, 2012). A "memória geracional” (Teixeira, 2010) baseada nos relatos dos "mais velhos" auxiliam os "mais jovens" em suas reelaborações e representações nos dias atuais, seja de si mesmos ou do grupo ao qual pertencem, ainda que essa memória esteja aberta, algumas vezes, às dissimulações diante de construções racistas que buscam inferiorizar o negro. Este fato está expresso na fala de Manuela, logo após ser questionada sobre a identificação do autorreconhecimento nas falas dos moradores "mais velhos" da comunidade de Barro Preto, colhidas através de entrevistas da qual ela participou.

Manuela: [...]O processo de reconhecimento, além disso que eu relatei para você, tem também esta parte de pesquisa com os mais velhos, ela foi feita depois do reconhecimento porque eu participei desse processo. Logo quando eu iniciei aqui em 2007, foi em 2008 nós fizemos entrevistas com os mais velhos aqui, tentamos montar, definir, quais seriam as ruas de fato que estariam pertencentes à comunidade quilombola[...]. 
Pesquisadora: E pelo que você observou houve um autorreconhecimento, nas falas...? Manuela: Houve sim. Eles contavam relatos sobre a origem do povo aqui, eles se identificavam com a cultura africana, mesmo sem saber que estavam se identificando. É um autorreconhecimento inconsciente, vamos colocar assim. Eles se percebiam com o legado africano e passando esse legado para seus filhos e netos, mas ainda com marcas muito branquiadas, sabe? É um pouco complicado, acho que um antropólogo e a gente estudando melhor para saber como de fato essas pessoas mais velhas se definem. Porque também eles ainda são subservientes, ainda têm um discurso de como se existisse um senhor e uma senhora que manda, a gente percebe nas pessoas mais velhas ainda, está muito forte isso. Tanto que eu acredito que está rebeldia dos jovens aqui na escola seja até uma forma de mostrar para os mais velhos de casa que eles são livres de fato, que eles podem determinar o destino, que não tem uma outra pessoa para dizer o que você deve ou não fazer. É uma forma equivocada, mas as vezes eu acho que até auxilia o mais velho a entender que ele também é empoderado, que ele também fez parte do processo, que ele é protagonista da história, porque ele ainda se vê como coadjuvante nesse processo histórico.

O racismo incide negativamente sobre a construção da identidade e da autoestima, condicionando pessoas negras a um comportamento reprimido em relação a si mesmas, ou até mesmo a se sentirem subservientes em relação aos brancos, fazendo do olhar branco o olhar com que se veem. Manuela observa na "rebeldia" dos mais jovens seu potencial em ressignificar e empoderar os mais velhos. Esse ressignificar é de suma importância para que se possa afirmar os repertórios identitários afrodescendentes, expressos cotidianamente nas vivências e no saber popular que se mantêm e seguem transmitidos entre as gerações. Além disso, cria-se a possibilidade de associar elementos da cultura e das histórias africana e afro-brasileira à memória cultural construída no bairro e de reconhecer a história do bairro e sua própria história como partes da memória social da comunidade: expressa-se, assim, o protagonismo de cada um diante deste processo.

Os relatos de Dudu e Manuela nos fazem pensar sobre o quanto nossas lembranças são inspiradas nas de outras pessoas, sobre as quais tecemos uma representação acrescentando novas lembranças, novos contornos e formas. É nesta perspectiva que se pode reelaborar a memória coletiva: buscando nas heranças da memória elementos para a superação de heranças da escravidão. Silva (2012) ressalta a importância da memória enquanto elemento de libertação que oportuniza a recriação da historiografia dos grupos quilombolas, a reinvenção de suas identidades e, por conseguinte, seu posicionamento político:

A recriação de histórias narradas e recuperadas na bibliografia e em campo remete não só às relações identitárias com o território, às relações sociais, remete principalmente a uma dor profunda de perceber-se marginalizado pela história construída pelos dominadores. Essa consciência do lugar a que foi destinado pela sociedade e a consequente determinação em mudar de lugar ou mudar este lugar, nos é informada pela memória reelaborada, reinventada num patamar de liberdade e luta política e social por seus territórios, isto é, em uma vivência de liberdade que norteia a seletividade das lembranças e que orienta a conformação de novas identidades, como a de quilombola (SILVA, 2012, p. 03). 
Os imaginários individuais e coletivos são acionados estrategicamente como elementos importantes nesse processo de identificação possibilitando, também, a transformação de grupos tidos como marginais em atores sociais. Esse processo ocorre de maneira relacional, em que o grupo se autodefine na relação com outros grupos sociais. Para Hall (2000, p. 109), a identidade está baseada na diferenciação, “[...] é mais o produto da marcação da diferença e da exclusão, do que o signo de uma unidade idêntica". Ou seja, para existir, a identidade precisa de algo exterior a ela, mas que cuja existência possibilite o seu próprio existir. Há, então, o estabelecimento de fronteiras mediante a seleção de traços culturais ${ }^{64}$ no interior do grupo, para que se diferencie de outros.

A memória possibilita essa seletividade, funcionando como um meio através do qual é possível elaborar fronteiras simbólicas. Através de fatos registrados na memória de cada indivíduo, o grupo reelabora sua historiografia formulando um campo simbólico, com significados que vão lhe dar um contorno singular. Esse campo simbólico consiste em cultura quilombola. Pensamos cultura, conforme ressalta Carneiro da Cunha (1986), não como um pressuposto, mas sim como um produto de um grupo. Quando falamos em cultura nas comunidades quilombolas, não estamos nos referindo somente às práticas e expressões acumuladas de geração em geração, mas às reelaborações que são feitas, ressignificadas, e outras que são produzidas no cotidiano do grupo. Como menciona Carneiro da Cunha (1986; 1989), a cultura é reelaborada e acrescida de novos significados:

[...] cultura original de um grupo étnico, na diáspora ou em situações de intenso contato, não se perde ou se funde simplesmente, mas adquire uma nova função, essencial e que se acresce às outras, enquanto se torna cultura de contraste (CARNEIRO DA CUNHA,1989, p. 44).

Nas relações sociais, signos e valores apreendidos no universo simbólico passam a ser compartilhados pelos membros do grupo em contraste com membros de outros, daí, o caráter contrastivo da cultura quilombola. Para Carneiro da Cunha (1986), alguns elementos culturais são forjados para se tornarem sinais diacríticos constituintes da identidade. Para a autora, a escolha desses elementos culturais depende de outros grupos, considerando que deve haver uma oposição entre sinais diacríticos selecionados como representantes do grupo e aqueles, do mesmo tipo, pertencentes a outros.

Estes aspectos estão de acordo com as definições de Oliveira (1976) sobre o caráter contrastivo da identidade. $\mathrm{O}$ autor utiliza o termo identidade contrastiva, considerando-a

\footnotetext{
${ }^{64}$ Segundo Carneiro Cunha (1986), traços culturais podem variar no tempo e no espaço sem que a identidade do grupo seja, por isso, afetada.
} 
essência da identidade, destacando que a afirmação da identidade ocorre em função da diferenciação e oposição com relação a alguma outra pessoa ou grupo. O caráter contrastivo da identidade também pode ser percebido na seguinte argumentação:

\begin{abstract}
A construção dessa nova consciência não é possível sem colocar no ponto de partida a questão da autodefinição, ou seja, da autoidentificação dos membros do grupo em contraposição com a identidade dos membros do grupo "alheio". Uma tal identificação - ("quem somos nós?" - "de onde viemos e aonde vamos?" - "qual é a nossa posição na sociedade?"; "quem são eles?" - "de onde vieram e aonde vão?" "qual é a posição deles na sociedade?") - vai permitir o desencadeamento de um processo de construção de sua identidade ou personalidade coletiva, que serve de plataforma mobilizadora. (MUNANGA, 2004a, p. 14)
\end{abstract}

Nas reflexões do autor acima citado, a afirmação da identidade está vinculada à elaboração de fronteiras simbolicamente construídas, utilizadas para definir o pertencimento a um grupo. Com base nessas considerações, podemos compreender que os grupos que se reconhecem por meio da categoria jurídica "remanescente de quilombos" estão, concomitantemente, reconhecendo-se como sujeitos de direitos e emergindo como sujeitos políticos. Essa categoria produzida externamente, quando colocada aos sujeitos quilombolas passa pelo julgo da memória, pois o grupo submete esse novo elemento aos significados elaborados e reelaborados, tendo em vista o passado e o contexto presente, podendo negá-lo ou rejeitá-lo. Ao mesmo tempo, esse novo impulsiona os sujeitos às reelaborações individual e coletiva de sua história, nas quais o quilombo surge como referência de lugar de memória que os identifica e que os leva a vasculhar, em suas lembranças, registros através dos quais possam tecer narrativas que perpassam, por sua vez, o surgimento da comunidade, sem desconsiderar seus contextos geográfico, histórico e político.

Com relação à elaboração das fronteiras, a memória funciona como um instrumento marcador de pertença, não só por figurar como elemento de construção de sentimento de identidade ${ }^{65}$, mas por seu caráter espacializado, dada sua intrínseca relação com o território. Pelo processo de produção da memória, um grupo conta sua história e se localiza no tempo e no espaço. Halbwachs (1990), reconhecia que a memória coletiva apresenta ao grupo um quadro de si mesmo, permitindo que se reconheça através de imagens sucessivas. A memória, portanto, tem como referência um espaço onde esse grupo circunscreve uma imagem de si, ao mesmo tempo em que constrói um sentido com um lugar comum.

\footnotetext{
65 Pollak (1992) reconhece a memória como fator importante na construção do sentimento de identidade, que proporciona coerência em níveis individual e coletivo.
} 
Assim, o espaço corresponde ao material em que a memória se conserva, portanto “[...] é sobre o espaço, sobre o nosso espaço - aquele que ocupamos, por onde sempre passamos, ao qual sempre temos acesso, e que em todo caso, nossa imaginação ou nosso pensamento é em cada momento capaz de reconstruir - que devemos voltar a nossa atenção [...]" (HALBWACHS, 1990, p. 143). O espaço geográfico/físico não deixou de ser uma referência para se pensar o que é o quilombo ou ser quilombola ou, ainda, ter identidade quilombola, mas deve estar ligado à história de vivência dos sujeitos naquele território. A fala de Dudu nos coloca diante dessa questão: como traçar fronteiras de um quilombo quando aqueles que estão fora da área demarcada também guardam a memória de pertencimento a este território? A questão da identidade ultrapassa a dimensão geográfica sem perder, contudo, a referência ao espaço, uma vez que a memória está a ele ligada. A memória recria a história do grupo com o espaço habitado que "[...] define o negro não como um sujeito genérico, mas sim o negro de uma comunidade ou grupo que ocupa um determinado território, uma terra que lhe pertence" (GUSMÃO, 1999, p. 145).” Dessa forma, o território se apresenta como um "marcador memorial" (ARRUTI, 2006) não só em termos materiais, mas simbólicos.

\subsection{Identidade e território}

Compreendemos território como um produto histórico-social decorrente de processos sociais e políticos, um espaço não somente material ou objetivo, mas subjetivo, envolvendo a dimensão simbólico-afetiva, posto que é fruto do vínculo afetivo e da ação coletiva de grupos humanos, espaço em que os homens tecem suas histórias, perpassadas por suas representações do mundo, do próprio grupo, de si e do "outro".

O território é constituído e ressignificado, a todo tempo, pelas relações sociais que nele se desenvolvem. Vale ressaltar que a territorialidade "[...] não provém do fato de viver num lugar, mas da comunhão que com ele mantemos" (SANTOS, 2007, p. 82), mas constitui conduta coletiva de um grupo de usar, controlar e se identificar com um lugar, convertendo-o em seu território:

\footnotetext{
O fato de que um território surge diretamente de condutas de territorialidade de um grupo social implica que qualquer território é um produto histórico de processos sociais e políticos. Para analisar o território de qualquer grupo, portanto, precisa-se de uma abordagem histórica que trata do contexto específico em que surgiu e dos contextos em que foi defendido e/ou reafirmado (LITTLER, 2002, p. 04).
}

O território deve ser compreendido em seu aspecto relacional, pois engloba as relações e conexões sociais, e de poder, entre agentes internos e externos. Assim, o desvelar sobre a 
ocupação e permanência de um grupo quilombola em determinado território revela sua resistência e estratégias de territorialização. A chamada "territorialização étnica" (LEITE, 2000) é entendida, aqui, como um processo sempre presente na trajetória histórica dos afrobrasileiros que, mesmo após a abolição, sofreram e continuam a sofrer com deslocamentos constantes, em função das segregações racial e residencial.

Silva (2012, p. 02) argumenta que, ao se organizar em prol de territorializar-se, o grupo "[...] está negando o lugar que lhe havia sido destinado, numa dada circunstância espaçotemporal, ou seja, está negando o lugar marginal que lhe havia sido designado pela sociedade abrangente"; dando continuidade às reproduções material e simbólica de seu modo de vida, o grupo estabelece condição de autonomia. A territorialização étnica tem um caráter defensivo, que se estabelece pela apropriação do espaço e luta pela continuidade da existência do grupo.

Em relação a quilombos, a compreensão da mesma vai além do entendimento de um uso comum de recursos naturais, vinculando-se, também, ao uso de um espaço compartilhado que envolve práticas sociais e reprodução de modos de vida. Disso decorre pensar a construção do território para além da referência às reproduções física e material, em termos de reprodução simbólica, fundamental na construção da identidade quilombola. Todo território guarda uma história de pertencimento apresentando-se, assim, como um "marcador memorial" (ARRUTI, 2006), importante no processo de autoidentificação. A singularidade de um grupo quilombola é evidenciada pela territorialização que, por sua vez, se vincula à sua memória coletiva. $\mathrm{O}$ território define o grupo e o sujeito pertencente a ele como singulares.

O negro faz parte de uma terra singular, uma terra que possui e da qual é possuído. Sua história nela se inscreve e ele próprio enquanto negro nela- a terra- encontra-se inscrito. Sua relação com ela é centrada em ritos, mitos, lendas e fatos. Memórias que contam a sua saga, revelam sua origem e desvendam, além da própria trajetória, a vida em seu movimento (GUSMÃO, 1999, p. 145) .

O território quilombola é uma construção em aberto, na medida em que se define em referência às relações sociais (HAESBAERT, 2006) e pode ser ressignificado conforme a construção e reconstrução das relações que o grupo desenvolve entre seus membros, com e no território, e com outros grupos. Nesse processo, o território assegura o desenvolvimento dos sentimentos de pertencimento, de identidade e de posse coletiva da terra figurando como um dado simbólico, essencial à produção da identidade quilombola.

Ao assumir-se como quilombola, o grupo inicia a produção de novos significados simbólicos e culturais no território, caracterizando uma dialética entre identidade e território, uma vez que ambos se produzem e reproduzem indissociável e constantemente. Nesse movimento cíclico, a memória funciona como um instrumento motor, ao oferecer elementos 
que recriam a história do grupo, perpassando a reafirmação de sua antiga ocupação e dando sentido ao espaço de vivência. Com a compreensão da unidade entre o que foi e o que é experenciado pelos sujeitos no contemporâneo, o espaço passa a ser visto não como simples lugar onde se mora, mas como um "valor".

O território aparece, na fala dos sujeitos da pesquisa, como marcador importante de pertencimento à comunidade quilombola. No caso da formação do bairro Barro Preto, nota-se que ainda não houve a demarcação do território quilombola por parte dos órgãos oficiais, mas houve a identificação, por parte do grupo que se formou através da Associação do Bairro, de algumas ruas como pertencentes ao território quilombola:

Dudu: [...] Então, algumas ruas à margem da linha foram escolhidas agora como quilombolas. Só que esta questão da cultura quilombola e de pertencimento vai transpor as barreiras físicas, já atravessou há muito tempo as barreiras físicas. Então, eu acho até de certa forma injusto você estar negando a identidade de uma pessoa dizendo assim: "Ah você mora aqui é quilombola" "Ah você não é quilombola não, tu não mora em tal rua". Eu acho que, de certa forma, isso está [...]está tomando, dizendo assim: "Você não tem o direito de pertencer a essa identidade, você não tem direito de ter essa identidade". Eu acho que a identidade quilombola ela vai atravessar as barreiras físicas. Porque as famílias quilombolas de origem não ficaram morando só ali, se espalharam logo. Foram se espalhando, se espalhando...

Este relato é uma crítica à demarcação feita a priori, mas também a interpretações mais rígidas que não reconhecem o crescimento do território original e a fluidez das relações e prováveis migrações de antigos habitantes. O ponto de vista de Dudu nos induz a pensar sobre a tríade entre identidade-território-memória, ao colocar em questão a situação daqueles indivíduos originários do bairro e que com ele compartilham uma memória, mas que já não o habitam.

Na fala de Dudu, o espaço geográfico/físico não deixou de ser uma referência para se pensar o que é o quilombo ou ser quilombola ou ter identidade quilombola, mas deve estar ligado à história de vivência dos sujeitos naquele território. Ou seja, a identidade está expressa como algo que ultrapassa a dimensão geográfica sem perder, contudo, a referência ao espaço, uma vez que a memória está ligada a ele. O depoimento nos leva a refletir sobre a fluidez da identidade e sobre o erro a que se incorre ao reduzi-la ou encerrá-la a uma definição ou perspectiva única e é "[...] preciso considerar o complexo do todo social. A identidade, assim como o processo de autoidentificação é fluido e se re(constrói) constantemente a partir das relações com os grupos e as diversas situações que a vida apresenta" (HAERTER, 2012, p. 57).

A identidade quilombola assume duas vertentes: uma individual, quando depende da consciência de cada membro para se reconhecer como quilombola, e ao mesmo tempo uma coletiva que para ser aceito como membro daquela comunidade precisa de sua anuência, de acordo com os critérios de pertencimento do grupo, estabelecidos coletivamente. Não cabe, portanto, a nenhum agente externo nem a rotulação nem a 
negação da identidade de um grupo étnico. Essa autoafirmação identitária diz respeito somente aos membros do grupo. Não basta apenas que um indivíduo afirme ou negue sua identidade étnica, é necessário que esta identidade seja referendada pelo coletivo (INCRA, não datado, p. 05, itálico nosso).

Embora tenha uma dimensão individual, a identidade quilombola deve se submeter ao reconhecimento do grupo. A questão que se abre é a de pensar uma proposta de definição justa, conforme a perspectiva enunciada, no sentido de conciliar demarcação geográfica e garantia de direito de afirmação da identidade para aqueles que compartilham de uma memória e se sentem pertencentes ao grupo. A comunidade Barro Preto encontra-se em processo de assumir-se como quilombola - parte de seus moradores ainda não se autoidentifica como tal e, portanto, os “critérios" de pertença e não-pertença ainda estão sendo pensados:

Carlos: Na verdade a gente veio ter o conhecimento depois de um professor da universidade de Conquista que faz parte de um quilombo também. Ele nos orientou assim: que a pessoa que é nascida dentro da comunidade e que tenha filho, que tenha descendente, mesmo que tenha saído e retornado [é quilombola]. Porque ela pode sair e retornar. Esse conhecimento é o entendimento que foi passado para a gente. Tem que ser desde a fundação do bairro... antes de 2007 [ano de reconhecimento da comunidade]. E depois de 2007, tem que ser descendente.

O depoimento de Carlos evidencia que a discussão sobre o reconhecimento das pessoas que não moram mais na comunidade passa pelo questionamento da origem, de quando e quanto tempo moraram no bairro, se geraram descendentes com pessoas que tem uma pertença racial ao grupo de origem etc. Outro ponto que poderá pesar nesse reconhecimento é o vínculo daquele que saiu com a comunidade, evidenciado, por exemplo, na manutenção de convivência com o grupo na forma de visitas. Coloca-se a questão de saber se as pessoas que não habitam mais o território mantêm com ele um "laço territorial" de pertencimento (valores simbólicos e afetivos), de modo que possam participar da construção de uma identidade quilombola coletiva. De qualquer forma, esse "laço" tem que ser pensado em termos de um pertencimento ao grupo e não apenas com o espaço devido à memória que o liga afetivamente a ele.

A questão do território aparece na fala dos sujeitos com o sentido de história construída, a exemplo do que se constata na fala de Pedro:

Pesquisadora: Há quanto tempo você mora aqui?

Pedro: Praticamente há 52 anos, eu não sou daqui, mas vim para cá praticamente com dois meses de nascido. Agora eu vou fazer 32 anos [tempo que reside na comunidade]. Pesquisadora: Você é quilombola?

Pedro: Eu sou, porque eu não conheci um outro lugar a não ser esse aqui. Praticamente nós vamos trabalhar lá fora, para mim é passagem...Como eu trabalhei em Minas, fiquei um ano em Minas, fiquei seis meses em São Paulo, fiquei um ano em Salvador, mas para mim é passagem, sempre volto para o mesmo lugar.

Pesquisadora: Seus pais nasceram aqui, são daqui?

Pedro: Não, meus pais são de Santa Inês.

Pesquisadora: Tem critérios para ser reconhecido oficialmente como quilombola? 
Pedro: Essas regras nós não sabemos ainda. Mas para mim [bate no peito] ser um quilombola é residir aqui há mais de dez anos. Não é chegou aqui com 3 anos e dizer "sou quilombola" só porque reside na comunidade. Ele reside sim numa comunidade quilombola, mas, para ser quilombola, tem que ser nascido de dez anos atrás.

Pesquisadora: E o que é ser quilombola?

Pedro: Ser quilombola é residir em um bairro onde o Mistério da Cultura veio e comprovou que aqui é quilombola, entendeu? E... e para mim eu não tenho mania de dizer o branco e o preto, para mim todos somos iguais, o sangue que corre na veia do branco, corre na veia do preto, para mim é tudo comum, tudo normal...o que importa são os direitos, o sentimento de valorizar e formar a comunidade quilombola.

A fala do depoente revela o sentimento de pertencimento à comunidade, uma terra tida como seu lugar, para a qual sempre retorna (GUSMÃO, 1999) e nos permite pensar sobre a diferença entre territorialização e territorialidade. A primeira, mais associada ao sentido de apropriação da terra surge, nas palavras do depoente, legitimada pela instituição "Ministério da Cultura"; a segunda aparece revestida de uma ação política identificada por Pedro que, no momento seguinte, discorre sobre a ação da Associação de Bairro da qual participou.

A territorialidade, segundo Campos (2007, p. 36), é “[...] um dos principais passos para o desenvolvimento da identidade espacial do grupo com espaço apropriado - atributo que se liga ao sentimento coletivo". Por esse viés, a identidade é compreendida com relação ao processo de territorialidade, que se estabelece nas relações entre os indivíduos com o espaço vivido e compartilhado e se expressa em sentimento de pertença.

Este processo de territorialidade envolve a representação que o indivíduo e o grupo tecem sobre si e o espaço habitado. Para Rezende (2008), essas representações consistem no imaginário social, formulado a partir das referências simbólicas que identificam os sujeitos de um grupo, mas também apontam aqueles que dele não fazem parte. Nessa perspectiva, o autor assinala que as representações formam identidades e identificam um grupo com relação aos demais. $\mathrm{O}$ apelo de Pedro à territorialidade, ao mencionar que "o que importa são os direitos, o sentimento de valorizar e formar a comunidade quilombola", possibilita a compreensão mais flexível de território como uma rede de relações pautada em dimensões simbólico-identitárioafetivo-político, que definem uma alteridade marcada pela distinção entre "nós" e os "outros", externos ao grupo.

Ainda com base na fala de Pedro, nota-se que o fato de ser quilombola está ligado ao reconhecimento jurídico do território como quilombo. A própria categoria "quilombola" vem de "fora", é atribuída pelo outro - segundo Dudu:

[...] Muitas pessoas moram aqui e não sabem nem que comunidade é esta. Você fala assim "comunidade quilombola" ... as pessoas falam assim: "Ah onde é a comunidade quilombola?” Muitas pessoas residem em comunidade quilombola e não sabem disso. 
A problematização do desconhecimento de muitos moradores sobre a condição quilombola da comunidade sugere fragilidade na organização política dos membros da associação do bairro na conscientização de seus habitantes sobre sua condição. Surgem, aqui, as seguintes questões: a mobilização em torno dos direitos que poderão ser adquiridos pela condição de quilombo só virá mediante o autoreconhecimento? E este só virá com a conscientização do que se trata a condição de quilombo e do porquê estão sob está condição? Além do mais, se o preconceito em torno do que é "quilombo", "ser negro", "ser quilombola" é um grande obstáculo para que as pessoas venham a se autoreconhecer, para o reconhecimento da condição de quilombola é preciso a superação de preconceitos atávicos, por isso a necessidade de diálogo e discussão (TEIXEIRA, 2010).

Segundo Haerter (2012, p. 59, itálico do autor), a categoria "quilombola" é jurídica e também identitária, pois leva à construção de identidade e à autoidentificação como quilombola: “[...] quilombola", não é, e nem poderia ser, uma categoria dada a priori e, sim vivida no cotidiano, com suas devidas tensões, relações de poder e hesitações”. Salienta-se que o conceito quilombola é de "fora" que se torna de "dentro" em razão de seus usos e da própria articulação política no interior da comunidade e no seu exterior. Passa-se de estranho para um estranho familiar e, por fim, a um aliado na luta por direitos. Pode-se dizer que a categoria jurídica dá "visibilidade" ao agente histórico quilombola, o que pode se solidificar através de uma organização política própria por meio, por sua vez, da formação de associações quilombolas que tratem de necessidades e problemas coletivos, reivindicando seu reconhecimento como sujeito histórico. Nesse ponto, vale refletir sobre o argumento de Arguedas (2014), segundo o qual não se deve deslegitimar a identidade quilombola, pois uma comunidade busca, por meio dela, visibilidade, além de melhores condições de vida. Estas se constituem dentro de ações estratégicas, as quais:

\footnotetext{
[...] estão em função dos desafios, problemas e oportunidades que cada grupo experimenta em determinado contexto social, geográfico e histórico. Aliás nessa relação íntima entre identidade e poder, é importante sublinhar que quem é obrigada a reivindicar uma identidade encontra-se usualmente em posição de carência e subordinação. Reivindicar uma identidade é negar o papel subalterno que a sociedade lhes deu e lutar por converter-se em agentes da sua própria história, converter-se em sujeitos (ARGUEDAS, 2014, p. 8, itálico do autor).
}

A partir da mesma perspectiva, Arruti (2006) assinala que a carência e a percepção de desrespeito motivam grupos quilombolas à luta, mas esta se solidifica, sobretudo, quando o grupo constrói politicamente sua especificidade identitária, que envolve a junção de interesses e aspirações do grupo a valores morais, tais como dignidade e respeito. Segundo Almeida (2002), quilombola é uma construção sociológica que se caracteriza, entre outros fatores, pela 
territorialidade específica de grupos sociais particulares. O Decreto $n^{\circ} 4.887 / 2003$ identifica "remanescentes das comunidades de quilombos" como "[...] grupos étnico-raciais, segundo critérios de auto-atribuição, com trajetória própria, dotados de relações territoriais específicas, com presunção de ancestralidade negra relacionada com a resistência à opressão histórica sofrida". Esta definição apresenta o território como elemento de construção da identidade quilombola, expressando a intrínseca relação entre eles, ou seja, indicando que ambos, território e identidade, são indissociáveis.

Para o autor, o território é um elemento de definição e contrastividade de um grupo quilombola com relação aos demais. Assim, o território quilombola não se define apenas pela resistência, mas pela memória e referência histórica comuns, pelos valores partilhados, entrelaçados e organizados por meio de uma ação coletiva, o que se traduz em territorialidade e etnicidade com finalidade de afirmação política de identidade. Nota-se o caráter construtivo desse processo, em que um grupo se reconstrói e reconfigura sua identidade sobre a insígnia de um renascimento, que se caracteriza, como sugere Arruti (1997), pela emergência de "novos sujeitos políticos" ou "novas etnias" (ALMEIDA, 2002). Alguns autores denominam etnogêneses (BARTOLOME, 2006), esse processo de emergência política e social desses novos sujeitos.

Tal processo resulta de reinvestimentos simbólicos do grupo sobre si mesmo, sua história e organização em situação de perda de direitos e desrespeito (ARRUTI, 2006).

\begin{abstract}
A identidade quilombola tem de ser, essencialmente, construída no interior do grupo para que seja reconhecida por outros, pois a identidade não é apenas o contraste, mas o reconhecimento da diferença. No processo de construção da identidade quilombola pelo grupo é necessário tecer uma continuidade histórica, evidenciando seu vínculo histórico próprio, ou seja, sua história singular, que o diferencia dos demais grupos. $\mathrm{O}$ lugar define o grupo como singular, não só por ser um patrimônio comum, mas porque guarda sua história singular, sua ligação com um grupo do passado. O mergulho em seu mundo se dá em direção ao "conector" do tempo singular - a história mitificada - para nele afirmar-se como sujeito e coletivo. Através dele, o lugar onde vive hoje e onde viveram aqueles que o antecederam se revela como espaço vital, lugar de soberania e de identidade. Espaço singular onde a vida cotidiana e a produção simbólica se aproximam, dentro de uma atmosfera emocional ou afetiva, criando canais especialíssimos, não língüísticos de comunicação, como diz Muniz Sodré: "O território torna-se continente de uma densidade simbólica, assimilável não pela racionalidade conceitual, mas sinestesicamente com corpo e espírito integrados numa atenção participante". A atenção participante consiste na retomada da dimensão cósmica em que a origem e o destino conformam a unidade de grupo, sua essência e como tal, no dizer de Muniz Sodré, sua possibilidade de ação (GUSMÃO, 1995, p. 127).
\end{abstract}

No caso de Barro Preto, algumas construções históricas, o Abarracamento e a Caixa d'água, são evidências materiais da antiga ocupação do bairro, constituindo-se em testemunhas da ligação com o passado. Essas construções são utilizadas como prova material da antiga 
ocupação, fundamentando a crença do grupo de que os negros foram os primeiros ocupantes do lugar e servindo para a afirmação da identidade. Por fim, essas construções podem vir a se tornar "lugares de memória" (NORA, 1984/1993).

Para o autor, criador do conceito de "lugares de memórias", esses lugares constituemse em uma interação entre história e memória. $\mathrm{O}$ autor considera que nas sociedades modernas há o desaparecimento da memória tradicional; nossa memória não é mais espontânea, ela é história, vestígios, restos. Segundo o autor, "Se habitássemos ainda nossa memória, não teríamos necessidade de lhe consagrar lugares. Não haveria lugares porque não haveria memória transportada pela história" ${ }^{66}$. A história se encarrega de destruir a memória, porque subverte as particularidades ao universalismo das coisas: "A história é a deslegitimação do passado vivo".

O autor argumenta que lugares de memória são necessários quando já não há mais uma memória espontânea e verdadeira; eles possibilitam uma reconstituição da memória-história. "O tempo dos lugares é esse momento preciso onde desaparece um imenso capital que nós vivíamos na intimidade de uma memória, para só viver sob o olhar de uma história reconstituída" (NORA, 1984/1993, p. 12). Segundo o autor, nos tempos modernos a históriamemória dá lugar à memória-história, sendo que a primeira envolve a percepção de que o passado não era verdadeiramente passado, ao passo que, na segunda, se tem a percepção de um passado morto. Desse modo, passamos de "[...] um passado visível para um passado invisível; de um passado coeso a um passado que vivemos como rompimento; uma história que era procurada na continuidade de uma memória a uma memória que se projeta na descontinuidade de uma história. Não se fala mais de 'origens', mas de 'nascimento",67

Nessa perspectiva, a memória não é mais prática social intencionalmente vivida, ela é voluntária, organizada, materializada e historicizada em lugares de memória: arquivos, monumentos, museus, cemitérios, entre outros. Esses lugares são, então, refúgio de "memórias perdidas", pois quanto “[...] menos a memória é vivida no interior, mais ela tem necessidade de suportes exteriores e de referências tangíveis de uma existência que só vive através dela" (NORA, 1984/1993, p. 14). Ainda segundo o autor, com o esfacelamento da memória, o sentimento de continuidade torna-se residual aos locais, que se mantêm como locais de memória por não haver mais meios de memória. $\mathrm{O}$ autor enfatiza que esses lugares são bastiões sobre os quais a memória se escora, necessários para guardar lembranças, não mais vividas

\footnotetext{
${ }^{66}$ Ibid., p. 08-09.

${ }^{67}$ Ibid., p. 19.
} 
verdadeiramente, que seriam eliminadas pela história. São, portanto, algo que não deveria ser, infelizmente necessários, pois:

[...] se o que eles defendem não estivesse ameaçado, não se teria, tampouco, a necessidade de construí-los. Se vivêssemos verdadeiramente as lembranças que eles envolvem, eles seriam inúteis. E se, em compensação, a história não se apoderasse deles para deformá-los, transformá-los, sová-los e petrificá-los eles não se tornariam lugares de memória. É este vai e vem que os constitui: monumentos de história arrancados do movimento da história, mas que lhe são devolvidos. Não mais inteiramente a vida, nem mais inteiramente a morte, como as conchas na praia quando o mar se retira da memória viva (NORA, 1984/1993, p. 13).

Para o autor, a memória pode ser diferenciada em memória verdadeira, nos gestos, hábitos, "nos ofícios onde se transmite os saberes do silêncio", no corpo, e a memória transformada em história, que se estabelece como um dever, não mais coletiva, mas individualizada:

É que esta memória nos vem do exterior e nós a interiorizamos como uma obrigação individual, pois que ela não é mais uma prática social. A passagem da memória para a história obrigou cada grupo a redefinir sua identidade pela revitalização de sua própria história. O dever da memória faz de cada um historiador de si mesmo. O imperativo da história ultrapassou muito, assim, o círculo dos historiadores profissionais. Não são somente os marginalizados da história oficial que são obcecados pela necessidade de recuperar seu passado enterrado. Todos os corpos constituídos, intelectuais ou não, sábios ou não, apesar das etnias e das minorias sociais, sentem necessidade de ir buscar de sua própria constituição, de encontrar suas origens. Não há mais uma família na qual pelo menos um membro não se tenha recentemente lançado a reconstituição mais completa possível das evidencias furtivas de onde a sua emergiu (NORA, 1984/1993, p. 17).

Estas reflexões sugerem que lugares de memória podem não ser formadores de identidade, mas de coesão, ao possibilitar uma continuidade, uma origem, algo que religue a memória ao passado e possa permitir aos indivíduos se reconhecerem como sujeitos de uma dada coletividade. Segundo o autor, tais lugares, em graus diversos, têm necessariamente três sentidos coexistentes: material (ancoram as lembranças), funcional (podem servir a transmissão dessas lembranças), e simbólico (expressão da memória coletiva e, por conseguinte, da identidade). No entanto, na concepção do autor, um determinado espaço "só é lugar de memória se a imaginação o investe de uma aura simbólica”.

No caso, as construções Abarracamento e Caixa d'água, tomados aqui como possíveis "lugares de memória", constituem-se em espaços físicos relevantes - não queremos cair nas artimanhas do “[...] fascínio empirista dos 'vestígios matérias' como prova” (ALMEIDA, 2002, p. 77), mas essas construções constituem pontos importantes na definição do território (terra) de Barro Preto como quilombo e podem vir a se tornar símbolos identitários para o grupo. No entanto, ainda não há um investimento simbólico coletivo sobre essas construções devido à 
dificuldade de obter, do poder público, seu reconhecimento como patrimônios culturais e históricos da comunidade de Barro Preto, embora isso já tenha sido pleiteado pela escola, segundo Maria:

[...] a gente queria que esses dois monumentos se transformassem em nosso patrimônio do bairro, mas a gente ainda não conseguiu. Por que a gente ainda não conseguiu? Porque esses moradores ainda não reconhecem esse lugar como um patrimônio contador de história.

Nora (1984/1993, p. 22) ressalta que para que seja constituído um lugar de memória é preciso, antes de tudo, uma vontade de memória - "o que os constitui é um jogo da memória e da história, uma interação dos dois fatores que leva a sua sobredeterminação recíproca".

Há uma necessidade de memória, para que os membros do grupo possam reconstituir com o grupo antigo uma história e, antes disso, há a necessidade de assumir um ponto de vista coletivo para que se possa lembrar, posto que é na reciprocidade e na memória coletiva que a história se baseia (Leite, 2000). No caso de Barro Preto, não há uma história escrita sobre a antiga ocupação do bairro, sobre seus antigos moradores (trabalhadores negros), mas há possibilidade de resgate e construção a partir da memória do grupo:

Hoje tem gente no bairro que não teve essa formação [sobre a origem do bairro] e nem sabe o que é isso? Tem. Mas tem aqueles que estavam presentes aqui, naquela época de viver na beira do rio, de ir lavar roupa na beira do rio, de pegar lata d'água na cabeça, de catar até ossos. (Dudu)

Como bem apontou Dudu, há um desconhecimento, por parte de alguns moradores, sobre habitarem em uma comunidade quilombola ou sobre o que esta vem a ser, mas há aqueles através dos quais é possível resgatar lembranças. Por meio da memória coletiva, esse grupo pode elaborar sua própria noção de quilombo. Aqui vale pontuar que este conceito também pode ser compreendido como um "lugar de memória" que identifica os sujeitos e, como todo lugar de memória, é fechado sobre si mesmo (imaginário social), mas aberto a significações, Sendo assim, através de reconstruções empreendidas pelo próprio grupo, pode contar o que escapa da história. Daí a importância da atenção à memória coletiva de grupos quilombolas, pois trazem possibilidades de ressignificações e novas elaborações do conceito.

A memória é um caminho a ser trilhado, através do qual os membros de um grupo constroem a imagem de si e que, de certa forma, unifica a origem de cada um dos membros do grupo com relação ao território que habitam, unificando o destino por eles compartilhado (Lima, 2003). A representação de cada indivíduo sobre si tem relação com o contexto histórico social no qual se insere, na intermediação entre passado e presente. Isso é expresso nos trechos 
que se seguem, em que os sujeitos tentam reconstituir a história do bairro a partir de suas próprias lembranças, ou de narrativas familiares e de membros da comunidade:

Pesquisadora: Sua avó nasceu aqui mesmo no Bairro Preto?

Dudu: Isso. Ela... pelo pouco que eu me lembro, que a minha mãe me contava... ela nasceu aqui já. Porque aqui, antes, quando passava a linha de ferro, a ferrovia aqui... A prefeitura acho que cedeu ou invadiram terrenos para fazer, porque aqui antes era meio cerceado, meio afastado de lá do Centro e tal... Então, acho que eles vinham... Eu não sei exatamente a origem dela, mas tinha a ver com isso assim... Começou a se formar um povoado aqui e aí como não tinha dinheiro para comprar terreno... Não sei se a mãe dela já morava aqui ou se ela veio morar aqui nessa região. Mas eu acho que a mãe dela já morava aqui e se formou uma comunidadezinha aqui, e aí começou a se espalhar e foi a formação do bairro.

$\mathrm{Na}$ entrevista com Pedro, ele fala sobre o Abarracamento, local onde habitavam os primeiros moradores negros do bairro.

Pesquisadora: O Abarracamento é aqui perto?

Pedro: É aqui pertinho, eu vou te mostrar.

Pedro: [...]E sobre a linha de trem de ferro aí... aí, passava a linha de fundo, aqui tinha uma parada onde os negros paravam...

Pesquisadora: Aqui, atrás da sua casa?

Pedro: É, eu alcancei a linha ainda, eu era menino. Não alcancei o trem, né? Mas ainda, a linha tinha.

Pesquisadora: Não tem mais a linha?

Pedro: Não, até tem aqui um corte, o boqueirão, já entulharam e tem casas. Aí o trem parava aqui e fazia uma baldeação, trocava a... tirava a cinza, né? ...para colocar lenha para o motor, por isso que isso aqui é Barro Preto. A cinza era jogada aqui em baixo, aí descia aqui, chegava no corpo de bombeiro, onde tinha a parada obrigatória mesmo. Parava ali e descarregava e no outro dia se mandava.

Pesquisadora: Você observa essa fala de origem da comunidade em outras pessoas? Pedro: Tem porque nós fizemos os trabalhos... as entrevistas com pessoas idosas, naquela época que nós fizemos, pessoas de 70, 80, 100 anos.

Pedro descreve os vestígios que se foram, dentre eles, a linha que, ainda menino, conheceu; suas experiências pessoais se entrelaçam às dos que partiram e às de outros que ainda permanecem na comunidade. Vê-se que "[...] os relatos que transmitem a história do grupo de uma geração a outra, transmitem também, a energia da história, i.e, sua força" (GUSMÃO, 1995, p. 127).

Ainda que não haja uma história registrada desse grupo, ele próprio, através da memória coletiva, pode tecer sua memória-história.

A história é a reconstrução sempre problemática e incompleta do que não existe mais. A memória é um fenômeno sempre atual, um elo vivido no eterno presente; a história, uma representação do passado. [...] A memória emerge de um grupo que ela une [...] A história, ao contrário, pertence a todos e a ninguém, o que lhe dá uma vocação para o universal. A memória se enraíza no concreto, no espaço, no gesto, na imagem, no objeto. A história só se liga a continuidades temporais, às evoluções, e às relações das coisas. A memória é o absoluto e a história o relativo (NORA, 1984/1993, p. 09). 
Esta diferenciação entre história e memória nos remete ao conflito existente entre escrita e oralidade, no reconhecimento da legitimidade da posse de terra de comunidades quilombolas. Gusmão (1995, p. 128, acréscimo nosso) assinala que há um conflito entre a tentativa das comunidades negras rurais de “[...] assegurar o 'direito costumeiro' [ao território], legitimado pela prática e pela oralidade com o direito de lei que impõe a necessidade de 'papel escrito' e reconhecimento legal da posse de terra". Segundo a autora, a lei escrita é fria e distante da realidade dessas comunidades, pois ao buscar o geral, nega o específico, colocando a oralidade sob suspeita, tal como a história escrita coloca a memória sob suspeita:

\begin{abstract}
Em sua maioria, as comunidades negras no meio rural não dispõem de documento comprobatório de seu direito e o "outro" toma o fato como meio de expor-lhe a negatividade de seu espaço, expondo-lhe a condição intersticial e temporária de sua relação com a terra. Diz-lhe assim, o que ele não é - dono da terra sua -, o que não tem ou não pode ter, a terra comum. A terra torna-se o elemento central desse processo posto que não é mais sua terra, o que faz com que a vida que até então lhe pertencia, passe a pertencer a outra esfera até então distanciada. Seu mundo, mundo dos pretos, passa a correr o risco de ser o mundo do "outro" Isto tudo porque o "outro" representa um mundo contido pelo universo da escrita, ou seja, pela ordem da palavra controlada e controladora (GUSMÃO, 1995, p. 126).
\end{abstract}

O argumento destacado nos auxilia na compreensão da memória como instrumento importante em que o grupo pode se apoiar para assegurar o direito à sua terra, pois seja no contexto urbano ou no rural, a memória do grupo pode fornecer elementos que confirmam e sustentam sua autoidentificação perante o mundo escrito e frio da lei. Nesse ponto, vale enfatizar a importância do critério de autoatribuição enquanto meio, ainda que indiretamente, de reconhecimento da oralidade dessas comunidades na esfera da lei escrita, embora saibamos que a decisão última de titulação de terras caiba ao jurídico, dimensão ainda controlada pelo "outro" opressor:

\begin{abstract}
A escrita, representada pelos "papéis", introduz no confronto e ensina aos homens, que através dos signos é possível "não somente significar o mundo exterior, mas apreendê-lo, tomar posse dele". A posse pela sociedade da escrita, faz do território, espaço cada vez mais representativo - do direito formal e jurídico, da lei, da propriedade - e o torna cada vez menos significativo, i.e, do significado, da história singular, da memória de grupo e base de sua reprodução social, física e simbólica ${ }^{68}$.
\end{abstract}

A memória recria a identidade do grupo, por guardar aportes de ancestralidade que podem ressaltar, através da luta de seus antepassados, o "direito costumeiro" à terra (Gusmão, 1995), que se traduz na luta do próprio grupo em determinar sua permanência nela, por meio de relações que se propõem a construir, em níveis simbólicos e sociais, o entendimento da terra como território.

${ }^{68}$ Ibid., p. 126. 


\subsection{Identidade e ancestralidade}

Compreendemos ancestralidade como um complexo relacional que liga o sujeito ou grupo a um ethos originário (ancestral), fundamentada na herança coletiva, nas relações e interrelações entre os indivíduos. Não se trata de algo estático e linear, pois é reatualizada em um movimento constante de produção simbólica. Na concepção de Ferreira-Santos (2012) a ancestralidade consiste em herança coletiva de um grupo, ou seja, é duradoura, ultrapassa a existência dos indivíduos pertencentes ao grupo em determinado momento. Segundo o autor, na constituição do nosso processo identitário articulamos os traços herdados da cultura à nossa trajetória existencial:

[...] aquele traço, de que eu sou herdeiro, que é constitutivo do meu processo identitário e que permanece para além de minha própria existência. Esse traço constitutivo do meu processo identitário me ultrapassa, eu sou herdeiro, não termina em mim, nem tão pouco eu o início. Eu sou apenas portador dele, ele está para além de minha própria existência. Isso me constitui, sendo consciente ou não desse traço, é aquilo que fica martelando ali no pilão, e que por vezes não me dou conta desse ritmo, dessa maneira cadenciada de eu agir, de eu pensar, de eu fazer as coisas, de me posicionar e agir, conceber e amar. (FERREIRA-SANTOS, 2012, p. 29, itálico nosso)

A definição de ancestralidade do autor - como traço que constitui os sujeitos, sendo eles conscientes ou não disso - nos remete à fala de Manuela, citada anteriormente, quando diz que os moradores de Barro Preto se identificam com o "legado africano", sem que tenham consciência dessa identificação, fato que leva a depoente a dizer que havia, entre os moradores mais antigos da comunidade, um "autorreconhecimento inconsciente" de sua condição de quilombola.

A colocação de Manuela - "Eles se percebiam com o legado africano e passando esse legado para seus filhos e netos, mas ainda com marcas muito branquiadas, sabe?" - nos remete aos caráteres "miscigenacionista" e "assimilacionista" da ideologia racial no Brasil, em que se procurava impor aos negros o embranquecimento de seus traços físicos e o abandono dos repertórios culturais de matriz africana (costumes, religião, etc), em favor de uma "cultura nacional" (Nogueira, 1954/2006).

A ancestralidade negra deveria ser boicotada em nome da integração social. Essas ideologias continuam a operar socialmente, por isso os desafios enfrentados por membros da comunidade estudada em identificarem elementos e práticas presentes em seu cotidiano como de origem africana ou afro-brasileira o que, por sua vez, repercute no seu autorreconhecimento enquanto quilombola. Lima (2003, p. 95) define tais repertórios culturais como: 
[...] o conjunto de bens materiais e imateriais de base africana, constituídos e processados nas vivências dos sujeitos e grupos afrodescendentes na sociedade e que se reportam em sua existência à ancestralidade africana. Inclui as festas, como extensão do fazer cotidiano, a própria lida do trabalho, o pensamento e a expressão que constitui a vivência sócio-histórico-filosófica-cultural das comunidades, bem como os bens materiais e simbólicos construídos nessas relações.

Como foi expresso na fala de Manuela, os repertórios negros (cultura, modos de vida, costumes, valores) são passados entre os habitantes da comunidade quilombola, portanto estão presentes em suas memórias. A forte presença desse repertório, "legado africano", nas palavras de Manuela, é o que caracteriza e comprova, de certo modo, a condição da comunidade como "remanescente de quilombo":

Pesquisadora: O que é identidade quilombola para você?

Manuela: Identidade quilombola é você saber que a sua cultura está ligada à cultura afro-brasileira, que a sua história está oitenta por cento ligada à história do negro que chegou aqui para produzir, chegou não, foi trazido, né?... Ele foi trazido... Sem com isso negar as outras influências de outras etnias [...] Identidade quilombola para mim é isso, é você valorizar e fazer reconhecer a cultura afro-brasileira e saber que ela é... Ela supera as outras na influência do seu comportamento e do seu ser. Essa é a identidade quilombola.

[...] nessa comunidade o legado mais forte é o legado africano por isso que ela é reconhecida como remanescente quilombola. E se o legado africano é o mais forte então, temos que reconhecer esse legado. Por que foi deixado? Como foi deixado [transmitido]?

Esses repertórios são “[...] referências de ancestralidade que ultrapassam a memória individual, e contribuem para a formação de uma memória coletiva" (GUILLEN, 2016, p. 174). O resgate da memória permite que a ancestralidade seja reconstruída em função de elementos oferecidos por ela. Nesse sentido, elementos presentes na memória de membros do grupo sobre a história de formação da comunidade podem revelar o vínculo com os ancestrais - a ancestralidade pode ser reconstruída em função desse vínculo, seja ele fictício ou não. A construção da ancestralidade, mesmo fictícia ou mitológica, pode auxiliar o grupo na construção de sua identidade, consistindo em algo que produz fronteira com outros grupos sociais.

Almeida (2002, p. 74), por sua vez, destaca que no contexto atual de rediscussão do conceito de etnicidade, ganha importância a consideração da "situacionalidade" pois, segundo ele, podem haver “[...] práticas que asseguram vínculos solidários mais fortes e duradouros do que a alusão a uma determinada ancestralidade.” Assim, o autor destaca o papel das ações coletivas do grupo e de representações em face de outros grupos para a construção de fronteiras étnicas. Entendemos que essas representações sempre passam pela referência a uma história, um passado, a uma ancestralidade. 
Ao articularem-se politicamente em torno do seu direito, grupos quilombolas vão, necessariamente, dialogar com referências históricas e políticas que marcam sua trajetória, fato que, em si, remete à ancestralidade. No caso de Barro Preto, a ancestralidade ligada ao território aparece como um sentido de identidade e um viés importante para demarcar fronteiras entre a comunidade e demais grupos. Lembramos, que no que concerne ao Decreto $n^{\circ} 4.887 / 2003$, a ancestralidade é parte importante na definição do que vem a ser território quilombola.

Para os participantes da pesquisa, a ancestralidade se mostra como um componente importante na constituição da identidade quilombola e se relaciona ao território ocupado. Esta relação pode ser observada nas expressões dos entrevistados, quando falam sobre a necessidade de ser morador da comunidade há algum tempo, e de se ter "raiz" nela, mesmo que ganhe expressão dentro de um procedimento burocrático, como aponta a fala de Manuela:

\footnotetext{
Pesquisadora: Então, quem é oficialmente reconhecido como quilombola são as pessoas que estão vinculadas, de alguma maneira, com aqueles que já estavam aqui há muito tempo?

Manuela: Isso. Então, alguém precisa atestar que você tem uma ancestralidade aqui no bairro. E quem é que atesta isso? É o presidente da associação do bairro. Eu faço a primeira etapa, você vem aqui, eu vejo o seu endereço...[...] Aí eu faço a primeira etapa, preencho a documentação e mando para o presidente da associação de bairro e o presidente da associação de bairro é quem atesta que ele tem raiz aqui na comunidade, que a família dele é daqui, que ele é filho de não sei quem e neto de fulano e por aí vai.

Pesquisadora: Quanto tempo mais ou menos tem que ter na comunidade?

Manuela: Tem que ter mais ou menos uns vinte anos de comunidade. Vinte anos para lá. É ser filho da comunidade. Nasceu com a comunidade.
}

O depoimento sugere que a ancestralidade quilombola, neste caso específico, deve ser pensada não só a partir dos ancestrais familiares, mas também com relação ao vínculo do sujeito com o território. Essa relação entre território e ancestralidade aparece também na fala de Pedro, anteriormente citada, quando explica a outros moradores porque aderir ao rótulo "remanescente de quilombo": "Eu disse não, quilombola é uma comunidade. Onde no passado tinha todos os direitos que tem hoje e ele não usufruía de nada e hoje o Ministério da Cultura está devolvendo tudo aquilo que foi negado a eles no passado".

A relação entre ancestralidade e território surge, portanto, relacionada: a uma história construída entre os sujeitos que lá estão e aqueles que estiveram no passado; e ao direito como materialidade de uma "herança ancestral", por consistir em uma reparação histórica. Nesse sentido, podemos inferir que a ancestralidade tem também um viés político, uma vez que, ao articularem-se politicamente em torno do seu direito enquanto quilombolas, os sujeitos vão dialogar com a referências históricas e políticas que marcam a trajetória da população negra daquele território. 
A referência à ancestralidade aparece em outro momento no relato de Pedro, quando refere o episódio da escolha do nome da Associação de Moradores: "Gente vamos parar de besteira, nós moramos aqui há muitos e muitos anos. E isso aqui já existia há anos e anos. Nossos próprios pais nem moravam aqui, isso aqui já existia gente, depois é que viemos. Que preconceito besta é esse?” Ao reivindicar a manutenção do nome Barro Preto, reivindica, ainda que de modo implícito, respeito à ancestralidade e à tradição dos antepassados.

A identidade quilombola, neste caso, não é algo pronto e que pode ser despertado pela retomada de um "passado ancestral", prontamente assumido pelos membros da comunidade, ela é construída na experiência social dos indivíduos envolvidos nesse processo. Uma dimensão da ancestralidade diz respeito a uma relação subjetiva da pessoa com seus antepassados, que não é tecida em conformidade com uma história homogênea e linear, fundamentada em certa continuidade, e sim no diálogo entre diáspora e origens, entre as heranças africana e afrobrasileira e os conhecimentos presentes e produzidos nos espaços sociais. Nesta perspectiva, considera-se a historicidade dos sujeitos envolvidos no processo.

Entretanto, a história oficial enviesada pela lógica racista encobertou memórias elementos da cultura africana com intuito de circunscrever a população negra em um "lugar" de passividade, alheia ao processo histórico, não reconhecendo seu protagonismo enquanto ator social cujas ações e opções foram criativamente articuladas no contexto da escravidão e fora dele. Atualmente, as pesquisas acadêmicas sobre a história social da escravidão procuram reescrevê-la considerando o protagonismo negro e defendendo seu entendimento como fator importante para a compreensão da histórica da escravidão e, por conseguinte, da sociedade brasileira (MATTOS, 2006).

Como exemplo, podemos citar a obra de Robert Slenes (1999), intitulada "Na senzala uma flor", em que se busca reconstruir a história a contrapelo, para melhor compreender as contradições e mudanças do sistema escravista. As colocações do autor evidenciam a importância da ancestralidade na vida de pessoas vitimadas pelo escravismo que provocou desterritorialização forçada e esfacelamento dos laços familiares; ressalta-se o caráter dinâmico dessa ancestralidade enquanto herança cultural que pode ser reconstituída pelos sujeitos e por eles atualizada de acordo com as experiências vividas.

Para o autor, ainda sobre um regime de intensa violência como na segunda metade do século XIX, na cafeicultura paulista, na senzala havia uma “[...] flor aquela nascida do encontro da cultura africana e afro-brasileira dos escravos com sua experiência no cativeiro" (SLENES, 1999, p. 133). Havia, entre os escravizados, uma herança cultural fruto de "recordações" da 
herança africana capaz de fazer brotar no chão inóspito do cativeiro uma flor "esperanças", ou seja, projetos de vidas que se deflagraram em estratégias de sobrevivência e resistência. $\mathrm{O}$ autor assinala que " [...] os escravos não eram seres anômicos, triturados até na alma pelo engenho do cativeiro, se tinham uma herança cultural própria e instituições, mesmo que imperfeitas, para a transmissão e recriação dessa herança" (SLENES, 1999, p. 133).

Ainda que a escravidão pudesse ter impossibilitado a formação de estruturas simbólicas próprias do mundo africano, fragmentos e experiências anteriores ligados a elas foram reconstituídos, houve uma reconstrução simbólica a partir da qual foi possível a transmissão das tradições. Os repertórios africanos do passado foram sendo produzidos e reconstruídos pela organização do grupo e sua capacidade de adaptar as estruturas simbólicas anteriores às condições de vida em que se encontravam no presente (BASTIDE, 1970, apud SANTOS, 2013).

Nesse sentido, “[...] as construções sociais devem ser entendidas como colchas de retalhos, cujas costuras são ressignificações de vivencias e práticas que no passado possuíam outros sentidos" (LIMA, 2005, p. 42). Essas vivências e práticas fazem parte das "recordações", da cultura herdada pelos escravizados que a utilizaram para interpretar o contexto no qual estavam inseridos, fazer escolhas e investir em "esperanças". As semelhanças entre as senzalas e as "habitações" de origem africana, assim como o uso da estratégia de casamento e laços familiares para a ampliação dessas "habitações" demostram que os escravizados se utilizaram estrategicamente de "recordações" para manipular o uso do espaço. Nesse sentido:

[...] as dimensões dos cômodos das senzalas brasileiras, seus materiais, técnicas de construção e plano interno não teriam sido totalmente estranhos aos escravos, dadas as coincidências entre certas imposições de seus donos e sua herança africana, e considerando-se que eles mesmos frequentemente tinham poder de decidir sobre alguns aspectos das habitações (SLENES,1999, p. 174).

O autor ressalta que uma dessas coincidências entre as senzalas e as "habitações" africanas é que ambas não possuíam janelas; segundo ele, a ausência de janelas pode ter sido imposta pelos senhores para evitar as fugas, no entanto tal imposição teria coincidido com a preferência dos escravizados que, com certeza, se valeram da situação provavelmente para imprimir "[...] suas marcas nas senzalas, naquilo que não estava sujeito a limites ou padrões alheios" $"$ 99.

O mesmo autor assinala, ainda, que alguns historiadores e viajantes, sem ter conhecimento sobre os padrões de arquitetura africana, viam no fato de alguns libertos

${ }^{69}$ Ibid., p. 166. 
preferirem choupanas sem janelas, a prova de que teriam se habituado às condições do cativeiro que lhes teria tirado a capacidade de elaborar projetos de vida. $\mathrm{O}$ autor diz que a ausência das janelas em seu local de moradia, ao contrário do que viajantes e historiadores do século XIX pensavam, demostram que a gramática de espaço de negros e negras guardavam a tradição africana.

Com relação ao casamento, Slenes (1999) explica que era utilizado como recurso pelos escravizados para ampliar seu local de moradia (semelhante ao que ocorria na África), tendo em vista que aqueles que eram casados recebiam um cômodo separado dos demais para se alojarem. Com o tempo, era possível conseguir construir outros barracos ligados ao barraco original. Dessa forma:

[...] ao pensar o casamento, os escravos, por serem manipuladores de uma gramática do espaço não inteiramente alheia às suas condições de cativeiro, teriam visto oportunidades que os historiadores de hoje, iguais aos grupos dominantes do século XIX, não percebem de imediato. Ter-se-iam interessado pelas possibilidades reais de aumentar a pequena área construída que estava à sua disposição e de ganhar mais controle sobre essa área, sabendo que aumentariam dessa maneira suas chances de atingir certas finalidades matérias e culturais: finalidades limitadas, porém de maneira alguma desprovida de significado ${ }^{70}$.

O casamento é um exemplo de estratégia familiar baseada no uso de estruturas simbólicas anteriores que revela a capacidade de adaptação das tradições diante de situações concretas e em conformidade com as circunstâncias. Nesse sentido, o autor afirma que a recriação da linhagem como princípio fundamental na organização do grupo foi também uma manobra essencial para a formação de grupos familiares, sua preservação e de transmissão de sua herança cultural. Assim, os negros em situação de escravidão (situação-limite) “[...] organizaram suas vidas, na medida do possível, de acordo com a gramática (profunda) da família-linhagem. Encontrando, ou forjando, condições mínimas para manter grupos estáveis no tempo, sua tendência teria sido de empenhar-se na formação de famílias conjugais, famílias extensas e grupos de parentesco ancorados no tempo"71

$\mathrm{O}$ autor segue observando que os africanos teriam agido conforme os integrantes de grupos bantu, que concebiam as raízes africanas e seus ancestrais descolados do tempo e do espaço, por isso presentes no grupo de parentesco, independentemente do lugar por este ocupado. Enfatizamos que este estudioso é especialmente sensível ao detectar, na pesquisa sobre a escravidão no sudeste brasileiro, a importância da família, principalmente no sentido de

\footnotetext{
${ }^{70}$ Ibid., p. 180

${ }^{71}$ Ibid., p. 147.
} 
linhagem, isto é, dos elos intergeracionais entre os escravizados. Esses laços com os ancestrais, segundo o autor, estavam presentes tanto nas etnias africanas matrilineares, como patrilineares.

Tal olhar é significativo. Até a década de 1970, a historiografia e a sociologia que se debruçavam sobre a comunidade negra, falavam da anomia, da promiscuidade sexual, da ausência de laços familiares entre os membros das comunidades negras, anteriores e posteriores à emancipação. Tratava-se de uma observação muito frequente nos viajantes do século XVIII e XIX, que atribuíam a ausência de laços de família mais à inferioridade do negro e à cultura tribal do que às condições de violência do trabalho compreendida, por sua vez, como fator de embrutecimento psíquico dos escravizados. Essa era principalmente a percepção senhorial, cujo olhar enviesado era também extremamente míope; fora questões de disciplina, os brancos sabiam muito pouco sobre a cultura dos plantéis cativos.

Mesmo a Sociologia, que acompanhou o destino dos negros no pós-abolição, como os primeiros trabalhos de Florestan Fernandes e de Fernando Henrique Cardoso, entre outros, continuou a falar de uma anomia reinante na comunidade negra, perceptível na inércia diante da miséria, na vulnerabilidade a doenças psíquicas, na instabilidade familiar, bem como na indigência, na violência, na prostituição e no alcoolismo. A incapacidade de autodisciplina seria consequência da falta da família e de laços comunitários fortes, que não ofereceriam educação mínima às crianças. Segundo esses autores, essa anomia teria ocasionado a marginalização social e econômica dos pretos, sua incapacidade de se adequarem às condições de trabalho livre e à sociedade capitalista moderna.

No plano da historiografia, os trabalhos de Hebe Mattos, Manolo Florentino e especialmente Robert Slenes, na esteira da reviravolta do que se havia produzido na historiografia angloamericana após a publicação do livro The World the Slaves Made ${ }^{72}$ proporcionaram um olhar diverso. Com base em pesquisas em fontes primárias, cruzando fontes diversas, detectou-se, surpreendentemente, a presença de famílias estáveis, não só mediante laços nupciais, como também no sentido de linhagens, laços intergeracionais que se mantinham vivos, mesmo dentro do contexto inóspito e violento das relações escravistas.

Hebe Mattos atribuía a existência desses laços a uma estratégia de dominação senhorial, uma vez que a presença da família era uma forma de pacificação da senzala, pois diminuíam fugas e revoltas na medida em que a família funcionava como refém dos senhores. Robert Slenes, embora concordando em parte com tal interpretação, acha que não se deve esgotar a

\footnotetext{
${ }^{72}$ ROLL, J. The World the Slaves Made. New York: Vintage, 1972. Segue referência da obra traduzida parcialmente para o português - GENOVESE, E. D. A terra prometida: o mundo que os escravos criaram. Rio de Janeiro: Paz e Terra/CNPq. 1988.
} 
família escrava no significado de controle. Argumenta que a família escrava, mesmo nas condições de separação e fragilização impostas, constituiu importante anteparo à força senhorial, funcionava como refúgio e fortalecimento dos indivíduos submetidos. E que tanto os laços de família como os laços de compadrio podiam ser fonte de solidariedade necessária à resistência, às revoltas e aos planos de futuro. Com a família, o escravo não só aprendia a evitar castigos, como tinha fontes de amor e simpatia indispensáveis para manter sua integridade psíquica, identidade cultural e a possibilidade de transmissão da cultura.

No sentido semelhante ao conceito de ancestralidade, Robert Slenes chama a atenção para a persistência de costumes africanos que sobreviveram à escravidão, como a manutenção nas senzalas e nas choupanas do fogo doméstico, mantido permanentemente aceso, e que, originário das culturas centro-ocidental da África, tinham um forte sentido simbólico de demarcar nos lares, as linhagens urdidas na comunhão com os mortos. É nesse sentido que, em um trabalho posterior, A arvore de Nzanda transplantada: cultos kongo de aflição e identidade escrava no Sudeste Brasileiro (sec. XIX $)^{73}$, Slenes se refere à simbologia da gameleira branca.

$\mathrm{Na}$ África centro-ocidental, principalmente na cultura kongo, a figueira africana é reverenciada como árvore que abriga nos seus galhos e amplas raízes os espíritos ancestrais. Trata-se do que chamam de árvore de Nzanda, que é plantada na fundação de um povoamento africano. Uma árvore semelhante à figueira africana, a gameleira branca, era plantada e reverenciada no Brasil nos terreiros e nas senzalas, e posteriormente nos locais de culto das religiões afro-brasileiras. Os negros acreditavam e acreditam que ela serve de guarita aos espíritos dos antepassados não só africanos, mas indígenas locais.

A ancestralidade perpassa a construção histórico-cultural do negro no Brasil, caracteriza as manifestações culturais, as tradições da cultura de matriz africana que dinamizam a experiência de grupos étnico-raciais funcionando como princípio regulador das práticas e representações sociais (OLIVEIRA, 2009). O que Slenes procura desvelar é algo que ficou oculto tanto para os viajantes do século XIX, quanto para muitos descendentes dos próprios escravizados.

No contex to brasileiro, há certamente dificuldades na reconstituição e reconhecimento das africanidades, posto que a transmissão das heranças culturais africana e afro-brasileira foi escamoteada pela lógica racista e pela violência racial, desde a escravidão. Ao mesmo tempo, essa violência reatualiza as marcas da escravidão, fazendo-as reincidir como trauma. A

\footnotetext{
${ }^{73}$ SLENES, R. A Árvore de Nzanda transplantada: cultos kongo de aflição no sudeste brasileiro e identidade escrava no Sudeste brasileiro (sec. XIX). In: LIBBY, D. C.; FURTADO, J. F. (Orgs.) Trabalho livre, trabalho escravo: Brasil e Europa, séculos XVIII e XIX. São Paulo Annablume 2006.p. 273-317.
} 
escravidão é um acontecimento tão intensamente traumático, “[...] que sua memória pode ser transmitida ao longo dos séculos com altíssimo grau de identificação" (POLLAK, 1992, p. 201) por parte daqueles que a "herdam". Segundo o autor, durante o processo de socialização é possível que ocorra uma identificação tão intensa com determinado passado que se pode concluir que a memória seja quase que herdada. Não somente por ele ter sido marcado por um evento traumático, mas pelo silenciamento em torno dele, ou pela maneira distorcida com que foram descritas historicamente as relações étnico-raciais, prevalecendo abordagens que as descreviam como dotadas de harmonia e cordialidade.

Segundo Santos (2013, p. 65), no “[...] Brasil alguns poucos estudos começam a se preocupar com a memória dos descendentes de escravos, ainda que tardiamente, dando voz não às vítimas, mas aos diversos atores daquele período da história”. A autora, ao discutir sobre memória traumática e a definição de trauma para Sigmund Freud, pontua que "[...] o trauma aparece como resultado tanto da natureza devastadora dos eventos sobre o indivíduo como da incapacidade da psique deste último de lidar com determinados eventos"74. Aborda-se a noção de pós-memória ${ }^{75}$, de Marianne Hirsh $(2008)^{76}$, que discorre sobre a possibilidade da reconstrução do passado de maneira criativa pelas gerações subsequentes à geração que vivenciou o evento traumático pois, ainda que haja ausência de narrativas em virtude do trauma, as experiências podem ser transmitidas através de sensações e emoções.

O silêncio sobre o passado, ou sua incompletude, observada no vazio das narrativas, provoca empatia na geração subsequente e se traduz em forte vínculo com a geração que sofreu o trauma (SANTOS, 2013 apud HIRSCH, 2008) ${ }^{77}$. O mesmo autor argumenta sobre a relevância do conceito de pós-memória para o entendimento acerca do período escravista no Brasil:

\footnotetext{
${ }^{74}$ Ibid., p. 63.

75 "Pós-memória descreve a relação que a geração posterior àquela que testemunhou traumas culturais e coletivos carrega acerca da experiência daqueles que vieram antes, experiências das quais se "lembram" apenas por meio das histórias, imagens e comportamentos em meio aos quais cresceram. Mas essas experiências lhes foram transmitidas de modo tão profundo e afetivo que parecem constituírem memórias de próprio direito". (HIRSCH, 2008, p. 106-107 apud FERNANDES, 2013, p. 66-67) "Essa memória recebida é distinta da lembrança das testemunhas e dos participantes contemporâneos aos fatos. Daí a insistência no 'pós' ou 'posterior' [...]". (HIRSCH, 2008, p. 105-106 apud SELIPRANDY (trad.), 2015, p. 124).

${ }^{76}$ Segundo Santos (2013) nessa obra Hirsch investiga os efeitos do Holocausto nos descendentes daqueles que sofreram experiências traumáticas em campos de concentração.

${ }^{77}$ Hirsch, Marianne. The generation of postmemory. In: Poetics Today, Durham: Duke University Press, 29:1, 2008.
} 


\begin{abstract}
O trabalho sobre pós-memória é importante para compreendermos que um passado traumático tem consequências sobre gerações subsequentes. No Brasil, sabemos que muito poucas são as memórias e narrativas sobre a escravidão. As antigas narrativas que mostravam instrumentos de tortura e escravos no tronco têm sido gradativamente abandonadas por estarem sempre associadas a diagnósticos de subordinação e vitimização dos escravos. A construção do passado dos descendentes de escravos tem ocorrido em torno de questões como a presença de traços africanos, em contraposição à assimilação e à adaptação cultural. A construção de memórias coletivas em torno de feridas históricas é sempre muito complexa. Contemporaneamente surgem diversas iniciativas de recordação de lembranças traumáticas que tem por foco refletir sobre práticas de abuso, ressaltando a resistência constituída, e exigir para os descendentes dos que sofreram atrocidades uma política de desculpas e reparação. Essas políticas da memória estão envolvidas com a recuperação ética das bases que fundam uma sociedade (SANTOS, 2013, p. 65).
\end{abstract}

Segundo podemos observar através do depoimento de Dudu, ao longo da entrevista em grupo, ele faz parte da quarta geração pós-escravidão. Segundo as narrativas de sua avó (mãe de sua mãe), sua bisavó teria nascido livre (lei do ventre livre). Nota-se que ainda que fosse reclusa em suas narrativas, como já mencionado, a avó foi capaz de transmitir à mãe a experiência da escravidão, por meio de sensações e emoções, posteriormente transmitidas a ele. Seu relato, portanto, evidencia a presença do trauma da escravidão presente na constituição da identidade quilombola.

As feridas históricas não se limitam ao passado referente à escravidão, por isso a necessidade de interrogação sobre o passado não se restringe a esse período, mas a todos os acontecimentos de opressão e descaso que envolvem a população negra até os dias atuais. A interrogação sobre o passado pode se traduzir em "imagens desestabilizadoras", como diz Boaventura de Sousa Santos (1996), imagens que denotam injustiças sociais relacionadas às condições de sofrimento a que historicamente determinado grupo foi submetido, assim como resistências por ele empreendidas ao longo do processo histórico. O grupo, ao reconhecer sua condição de opressão e sofrimento como fruto de alternativas que poderiam ter sido evitadas, reinventa o passado e retira dele o sentido fatalista que lhe interpreta muito mais como destino a ser superado no futuro, do que como produto da iniciativa dos homens.

Na medida em que o passado deixar de ser automaticamente redimido pelo futuro, o sofrimento humano, a exploração e a opressão que o habitam passarão a ser comentário cruel sobre o tempo presente, indesculpável porque continua a ocorrer e porque poderia ter sido evitado pela iniciativa humana. As imagens só são tão desestabilizadoras na medida em que tudo depende de nós e tudo podia ser diferente e melhor (SANTOS, 1996, p. 23).

A autor segue argumentando que "[...] só as imagens desestabilizadoras podem restituir nossa capacidade de espanto e de indignação"78. Nos níveis individual ou grupal, essas

${ }^{78}$ Ibid., p. 23. 
“imagens desestabilizadoras" podem ser capazes de irromper em posições de empoderamento de identidade, enfrentamento e reencontro com a ancestralidade:

Dudu: Na adolescência eu também tinha muita raiva. Diziam assim: "Seu preto do beição". Meu apelido era esse "beição". Nossa! Eu morria de raiva. Oh, ódio que eu sentia a minha vida toda. Pensava assim: "Oh, porque eu fui ter essas características de negro?" Aí foi o momento que eu comecei a sentir raiva da minha cor. Sentia raiva...

Pesquisadora: .... Do próprio corpo.

Dudu: É, isso. Por causa disso: "Você é negro do beição", "Olha aí beição tem um bundão", "Beição é assim", "Negro tem bundão" ... Aí, falava tudo isso, sabe? E me descrevia assim com certas características físicas de negro. Eu ficava assim: "Ah, não queria não, não queria, não queria, não queria ser negro". Mas quando eu comecei a crescer que a mente começou a mudar, que você está ali em ebulição, né? .... Você começa a mudar, a se transformar e qualquer opinião dos outros vai lhe afetar...Então, com o tempo quando eu comecei a ler...Então, de certa forma a leitura, a educação, ampliou essa minha visão, ela abriu. E quando eu li aquele poema de Castro Alves foi tipo um...um murro, um choque, falou assim: "Acorda, olha o que os negros sofrem durante tanto tempo". Tem um também que eu acho muito forte, um trecho que a professora levou em sala de aula, que ele falava bem assim: "Os povos dessa terra animais do universo. Deus onde estais Deus?" Perguntava assim no poema, ele fazia indagação onde Deus estava que o povo da África servia de animais do universo. Falava assim que a África era o pasto que às vezes as pessoas iam extrair e que o povo negro era animais do universo. Então, eu achei muito forte isso, Animais do universo. Quando é que um ser, um ser humano vai ser comparado a ruminantes, pessoas que exercem o trabalho, só está aí para trabalhar, não pensar, não raciocinar, só trabalha, trabalha forçado. Então, nisso eu ficava pensando assim: "Eu tenho que parar com isso, tenho que parar com esse pensamento preconceituoso". Foi então quando eu comecei a me encontrar e hoje quando eu falo assim: "Eu sou negro". Sinceramente de todo coração, de lá do fundo, quando eu falo assim: "Eu sou negro e ninguém está aí para me oprimir". Eu faço um respiro de alívio, enfim... enfim eu não me preocupo mais com meus lábios, com meu nariz, com a cor da minha pele. Enfim eu não me preocupo mais com certas coisas, sabe? ...que eu trago da minha cultura. Eu faço assim: (respira com alívio) "Aí, enfim eu estou livre, ninguém mais, mesmo que queira, vai me oprimir. Eu não vou me deixar ser oprimido como eu deixei”. Então, isso foi um... (gesto de respiro e alívio) ...sabe? Quebrou, rompeu com os grilhões, e eu me aliviei. Então, antigamente, quando alguém olhava para mim: "Tu é preto". Era a briga: "Não sou não". Hoje em dia fala: "Menino tu é preto". Eu falo: "Ainda bem". Hoje a minha irmã fala para mim: "Tu é preto". E às vezes eu até brinco... brinco assim, eu brinco, mas é uma brincadeira que é uma crítica. Quem me conhece sabe que eu sou muito crítico, que as vezes eu só estou alfinetando ali... Então, a pessoa vem de lá: "Ah não sei o que e tal". Eu falo: "Tu é preto". Para a pessoa parar e pensar. Não no sentido pejorativo. Mas a pessoa vem: "Eu fiz isso não deu certo". Eu falo: "Sabe porque o preto só anda sendo marginalizado". Aí, a pessoa para e pensa...

A veracidade histórica apresentada para Dudu através do poema de Castro Alves que retrata o tráfico e sequestro de pessoas negras na África, faz com que ele lance sobre o passado “interrogações poderosas" (SANTOS, 1996). As "imagens desestabilizadoras" que emergem nesse momento o coloca frente à possibilidade de lidar com a alteridade, permitindo o questionamento do olhar do outro sobre ele. É “"[...] através do outro que se revela e dialoga comigo, que constituo o meu processo identitário, articulando os traços herdados da minha cultura (ancestralidade) e a sensibilidade própria da minha trajetória existencial no percurso formativo [...]" (FERREIRA-SANTOS, 2012, p. 27). 
É por meio da alteridade que posso questionar quem eu sou, na medida em que, o que sou para mim é, muitas vezes, reflexo do que sou para os outros, do que os outros dizem que eu sou. Eu sou uma eterna construção do eu com o outro. Sendo esta construção dialógica, o que eu digo que sou para o outro também influencia na concepção que o outro tem de mim. A história de auto-reconhecimento de Dudu ressalta bem como essa dimensão da alteridade interfere na construção da identidade e na forma como cada sujeito se relaciona com seus traços, com seu corpo.

A ancestralidade é reafirmada por Dudu quando há identificação entre a humilhação por ele sofrida e a opressão histórica sofrida pelo povo negro. Dudu percebe que ao rejeitar o próprio corpo estava a impingir sobre si sofrimento reflexo daquele que os outros lhe impingiam, e, portanto, fortificando, de certo modo, esta lógica de opressão. Seu depoimento evidencia que a construção de identidade negra positiva não surge apenas pela geografia do corpo, mas implica em um encontro com o próprio corpo, reconciliação com ele e com a cultura herdada, ou seja, uma religação com a ancestralidade (SANTOS, 2014).

A religação de Dudu com sua ancestralidade ocorre quando se depara com uma “situação-limite" (FERREIRA-SANTOS, 1996), sua adolescência - enquanto crise relativa à construção identitária (ERIKSON, 1968) -, momento em que a relação que tinha com o próprio corpo se apresenta como insuportável. Vemos como o resgate de sua ancestralidade lhe permitiu uma ressignificação de si como negro, uma religação e uma releitura em relação à:

[...] sua querência, seu rincão, seu lugar, sua própria paisagem. Nas situações limites
é que o ser humano revela sua face. É nessa situação limite que eu atualizo o mito de
origem e onde me propicio tanto a religação com essa minha ancestralidade, na sua
estratégia de religare, quanto da sua outra possibilidade latina que é relegere - eu me
ligo a pessoas e passo a reler o mundo, passo a interpreta-lo de uma outra maneira
quando exerço essa pertença. É quando, então, nós assumimos como herdeiros de fato,
não de uma maneira inconsciente, mas com uma tomada de consciência da própria
pessoa com relação a sua querência. Portanto aí, eu me aproprio dessa produção
imaterial dos seus sentidos e de sua dinamicidade, de sua plasticidade (FERREIRA-
SANTOS, 2012, p. 31, itálico do autor).

A experiência de Dudu evidencia que a ancestralidade é um elemento importante no processo de construção da identidade negra, que envolve dinamicidade e plasticidade:

\footnotetext{
Se eu entender a ancestralidade dessa forma, como esses elementos constitutivos do meu processo identitário e que, por sua vez, estão presentes no mito de origem de meu grupo cultural, da própria sociedade; percebemos também que eles são atualizados constantemente. Daí seu caráter dinâmico, sua plasticidade, ao contrário de uma primeira ideia errônea de que a ancestralidade se confunde com a inércia e mesmice, formol e empalhamento museais (FERREIRA-SANTOS, 2012, p. 29).
}

Ancestralidade é algo que nos liga à nossa identidade histórica - quando a reconhecemos, temos a consciência de algo que faz parte de nós, portanto, através dela, 
reconhecemos quem somos e, se a reivindicamos, fazemos dela uma arma política para nos tornarmos aquilo que pretendemos ser. Há uma atualização dos elementos constitutivos do seu processo identitário, seu corpo, sua concepção de si. Este passa a ressignificar seus atributos vistos como negativos, constrói o sentimento de pertencimento ao grupo étnico-racial negro, evidenciando que ser negro vai além de assumir seus traços fenotípicos de ascendência africana, se estende a assunção de sua ancestralidade cultural. A fala de Dudu é uma belíssima e poderosa narrativa do despertar da consciência negra.

\begin{abstract}
A consciência negra está ancorada na cultura e história nas lutas travadas por nossos ancestrais contra a escravidão, o racismo e a opressão. A Consciência negra é a possibilidade de fazer, coletivamente, um futuro de dignidade e liberdade, que fundado na ancestralidade e na cultura, é um eixo de conhecimento, de referência identitária e de energia vital, traduzida em dinâmica de resistência, de desconstrução e reconstrução. (CARDOSO, 2001, p. 214)
\end{abstract}

Por meio da fala de Dudu vemos o quando o processo de construção positiva da identidade negra é trabalhoso, passa por compreensões subjetivas e sociopolíticas e "[...] envolve a desconstrução da ideologia racista a partir da compreensão de processos de dominação, bem como a elaboração psíquica dos traumas sofridos em função dessa ideologia" (SANTOS, 2014, p. 111).

Abordamos, até o momento, a ancestralidade em relação, sobretudo, com a herança cultural. Nesse sentido, vale ressaltar as colocações de Oliveira (2009), que toma a cultura como movimento de ancestralidade comum entre "territórios de referências" - continente africano e território brasileiro africanizado. $\mathrm{O}$ autor ressalta que a história do Brasil deve ser repensada a partir do legado africano para não incorrermos no risco de perdermos a profundidade e qualidade do conhecimento sobre nós mesmos. “[...] A brasilidade, em muito, é tributária da africanidade. As africanidades re-desenham e re-definem a identidade nacional e, com isso, o projeto político, econômico e social brasileiro" (OLIVEIRA, 2013, não paginado). Nesse sentido, africanidades são:

[...] reflexos dos princípios sociais de matriz africana, amparados pelos aspectos filosóficos africanos como diversidade e a integração, a ancestralidade e a tradição, que norteiam e orientam as vidas dos povos africanos e também de seus descendentes na diáspora (CUNHA JUNIOR, 2007, p. 189).

No nosso entender, as africanidades não estão fundamentadas em especificidades históricas e culturais referenciadas em uma África idealizada e imaginada, a ser recuperada pela memória, assim como não correspondem a princípios fixos provindos do continente africano, pois são recriadas de acordo com o contexto. As mesmas oferecem uma contranarrativa, 
apresentam o que estava ali e não era identificado, o que foi transmutado ou escondido e naturalizado como ausente.

Nessa perspectiva, até que ponto a formação da identidade quilombola encontra-se influenciada pela constituição de uma identificação com as africanidades? O desenvolvimento da identidade quilombola está vinculado ao reconhecimento de que as relações sociais estabelecidas na comunidade são perpassadas por elas e pela ancestralidade negra. Reconhecer esta última não é necessariamente dizer-se negro ou reivindicar uma identidade negra, mas saber que elementos de africanidades também fazem parte daquilo que o constitui.

Na concepção de Oliveira (2013) a ancestralidade é a forma cultural negro africana recriada no Brasil que possui uma epistemologia própria denominada cosmovisão africana. Segundo o autor, trata-se de uma cosmovisão africana recriada em um contexto diásporo especificamente brasileiro "[...] atualizada nas manifestações culturais dos afrodescendentes, bem como em seu modo de organizar suas instituições - atualizando, no cotidiano, sua cosmovisão originária”. (Não paginado)

Ancestralidade se relaciona ao território, à memória, à cultura, ao corpo, à experiência; não é somente consanguinidade e parentesco ou um conceito, trata-se de uma categoria analítica que produz sentidos, interpretações, compreensões sobre a nossa experiência no mundo e nosso agir sobre ele. Ela se relaciona. "[...] se alimenta da experiência de africanos e afrodescendentes para compreender essa experiência múltipla sob um conceito que lhe dá unidade compreensiva, sem reduzir a multiplicidade da experiência a uma verdade, mas, pelo contrário, abre para uma polivalência dos sentidos”. (OLIVEIRA, 2009, não paginado).

Para o autor, a ancestralidade enquanto categoria é universal e singular, na medida em que abrange todas as experiências de africanos e afrodescendentes, ao mesmo tempo em que singulariza cada experiência, ressaltando seu sentido e contexto específicos. $\mathrm{O}$ autor ressalta o modo com que recriamos a cosmovisão africana no Brasil, forjando uma singularidade que nos é própria:

Nos jogos de corpo preservamos nossos sistemas de pensamento; na arte do povo, mantivemos nossos segredos e os publicizamos; na estética negra fabricamos nossa potência filosófica e científica, ao mesmo tempo, com tensão, mas sem conflito entre elas. Em nossas religiões desenvolvemos nossa medicina, nossa economia, nossas línguas e nossa política mui singular de relações com o Outro-Natureza, o OutroOutro, o Outro-Simesmo. Invertemos a lógica do sagrado e do profano. Profanamos o sentido da religião hegemônica e profanamos nossa própria religião. Transformamos em festa os episódios da tragédia. Rimos da miséria e da violência. Reverenciamos nossos pactos com o contexto. Desdenhamos de estruturas estáticas. Enlouquecemos na diversidade que criamos e perdemo-nos nos labirintos que soubemos produzir, mas não soubemos resolver. Produzimos nossa própria África e nossa subjetividade nos regatos de fluxo e refluxo que não param de nos atravessar. Explodimos com o conceito de raça e, ao mesmo tempo, reificamo-lo com força ancestral! Saímos das 
políticas generalistas e generalizamos as políticas afirmativas, num contrassenso que nos caracteriza. Jamais fomos modernos, mas tampouco medievais, contemporâneos...Somos extemporâneos sem sermos nietzscheanos. Somos africanos dentro de nosso próprio tempo residindo e conflitando com o tempo do Outro, que somos nós mesmos. Não nos confundimos, mas não deixamos de ser mestiços. Somos Africanos, mas de um jeito possível apenas no Brasil (OLIVEIRA, 2012, p. 39).

\subsection{Identidade e religião}

A religião surgiu como um elemento importante para se pensar a construção da identidade quilombola na comunidade de Barro Preto, cujas relações cotidianas revelam os resquícios vivos da história de encontros e desencontros entre as religiões presentes no contexto da sociedade brasileira. A discussão sobre o preconceito em torno de religiões afro-brasileiras emergiu com bastante força no grupo dos alunos. Segundo os depoentes, atualmente há um forte predomínio das religiões pentecostais, no interior da comunidade o que, por conseguinte se repete na escola. Todavia há também, ainda que em número reduzido, adeptos de religiões afro-brasileiras em ambos os contextos, da escola e do quilombo.

Os depoimentos foram divergentes quanto ao número de terreiros presentes na comunidade, mas sinalizam que há aproximadamente entre dois a três, e alguns em suas proximidades; um deles se chama Marujo ${ }^{79}$. A presença de terreiros na comunidade foi sendo cada vez mais restrita ao longo dos anos, como relata Carlos, ao buscar na memória, lembranças do bairro em tempos mais antigos:

[...]E na época aqui e eu acompanhei porque era menino... Tinha muitos pontos de cultura, o candomblé era muito, hoje acabou mas ainda tem...Tem dois terreiros hoje de candomblé, de umbanda não.

No atual estado das coisas ou, digamos, da interpretação delas, para pensar o lugar que as religiões de matriz africana ocupam na sociedade é preciso olhar o contexto social brasileiro atual. Desdobra-se, daí, outra afirmação: o lugar que essas religiões ocupam no Barro Preto está em estreita relação com as transformações sociais pelas quais essa comunidade passou ao longo de sua história, inserida em um contexto social e político mais amplo marcado por um expansionismo das igrejas pentecostais. Segundo Prandi (2003, p. 25), estas utilizam o ataque, seja em templos religiosos ou nas mídias, como meio de expulsar as religiões afro-brasileiras do cenário religioso, como estratégia marcadamente expansionista.

[...] há igrejas evangélicas em que o ataque às religiões afro-brasileiras e a conquista de seus seguidores são práticas exercidas com regularidade e justificadas teologicamente. Por exemplo, na prática expansiva de uma das mais dinâmicas igrejas neopentecostais, fazer fechar o maior número de terreiros de Umbanda e Candomblé

\footnotetext{
${ }^{79}$ Marujo é a personificação de uma força cultuada no Candomblé.
} 
existentes na área em que se instala um novo templo é meta que o pastor tem que cumprir.

Embora o número de adeptos das religiões afro-brasileiras possa variar de região para região, considerando as características locais, o autor observou que, nas duas décadas que antecederam a escrita de seu artigo, houve um decréscimo geral dos índices de adeptos. $\mathrm{O}$ autor destaca que, nos dias atuais, em virtude da legitimidade de liberdade religiosa, os indivíduos teriam menos constrangimento em se autodeclarar pertencentes a essas religiões. Dessa forma, dentre as razões que explicam esse decréscimo, enfatiza -se as fortes agressões dirigidas às religiões afro-brasileiras, sobretudo por parte das religiões neopentecostais.

Essas religiões, em sua generalidade, pregam discursos que estimulam não somente a rejeição das religiões afro-brasileiras, como também reproduzem preconceitos e sua discriminação. Fato que pode ser percebido na fala de Dudu:

Esses dias mesmo eu visitei uma igreja na comunidade, eu passei e disse certa coisa em relação à escola.... Eu sou evangélico, mas com certo tipo de visão eu não concordo, em relação... Fica aquela coisa de nós contra eles... Tipo, nós evangélicos contra as religiões de matriz africana. Eu não concordo com isso. Eu acho que tem que haver o respeito. Ao mesmo tempo que eu concordo com as questões do evangelho e tal.... Mas tem que ser abordado com respeito. Ele abordava com uma visão preconceituosa com relação às religiões de matriz africana. Então, esse dogma a ser quebrado com relação a esse tipo de coisa... Quilombola, quilombola.... Eles querem atrelar assim... o Candomblé a um coisa ruim, entendeu? Então, é uma coisa que vai levar um certo tempo para ser desfeito, dissolvido... [...]

Interessante notar que ele reconhece o prejuízo do não reconhecimento e do preconceito contra as religiões de matriz africana para o ressignificar da identidade pela comunidade, processo que tem sido empreendido especialmente pela escola - ponto que discutiremos em capítulo dedicado ao papel da escola na comunidade.

Embora pareça contraditório sinalizar a importância das religiões afro-brasileiras na construção da identidade em uma comunidade quilombola de predomínio de evangélicos, a importância se dá justamente porque é necessário compreender que o preconceito com relação às religiões afro-brasileiras constitui barreira à adesão dos moradores do Barro Preto às ações de reconhecimento da comunidade como remanescente de quilombo, visto que circula entre eles a visão de que ser quilombola é ser pertencente a essas religiões. Logo, ser quilombola é algo negativo e o termo quilombola é conotado de forma pejorativa, conforme enfatiza Iara, quando questionada sobre a adesão dos moradores à identidade quilombola:

Então, alguns moradores eles nãos se veem [como quilombolas], pelo menos na rua onde minha mãe mora, é muito difícil eles se veem como quilombo, quilombolas. Até é difícil você chegar para eles e dizer que eles são quilombolas, vai parecer até uma ofensa, porque eles não se consideram. Porque falou em quilombo a maioria já pensa 
em religião afro-brasileira e aí já vem o preconceito embutido dentro dela [da palavra quilombo].

Em pesquisa realizada na comunidade remanescente de quilombo de Remanso (Lençóis, BA), Costa (2015) também identificou essa problemática, que ilustra tensões ocasionadas pelo preconceito contra as religiões de matriz africana. Segundo a autora, muitos homens e mulheres evangélicos filhos de pais idosos os estavam abandonando por serem adeptos do Jaré.

$\mathrm{Na}$ escola da comunidade de Barro Preto, esse preconceito é algo recorrente e tem sido uma grande barreira no processo de consolidação de uma educação voltada para o ensino da cultura e histórias africana e afro-brasileira. No capítulo, dedicado à educação quilombola, retomaremos essa discussão, visto que o preconceito contra as religiões de matriz africana surge como um dos principais desafios enfrentados pela escola em sua tentativa de ressignificação dos valores culturais e da própria construção da identidade quilombola. Podemos ver, a partir da discussão do grupo, a efetividade do discurso que demoniza os valores culturais de matriz africana e seus efeitos no funcionamento na comunidade, nas relações que seus membros estabelecem entre si e com o exterior.

As relações no microespaço da escola vêm revelar o que ocorre no espaço mais amplo da comunidade. Uma resistência do mesmo tipo daquela que buscava impedir a nomeação da associação do bairro, como Barro Preto, parece estar em voga neste momento.

Há algo sobre o que não se deve falar, que se deve esquecer, para não correr o risco de se contagiar. Como se tentassem apartar de si o que os outros lhes atribuem (demoníaco, ruim) e, que, ao mesmo tempo, está internalizado, alguns membros da comunidade separam de si algo que diz respeito à sua história, sua ancestralidade (crenças tradicionais). É o que evidencia Dudu em sua fala:

Negar, isso resta aqueles que querem se encaixar em padrões diferentes daquele que seus ancestrais tinham. Isso se deve a fatores externos [fora da comunidade] e isso os leva a procurar padrões além dos "muros" da comunidade. É muito difícil fazer com que não neguem, já a negação disso discorre de uma gama de coisas tidas como certas.

A demonização de crenças e práticas afro-brasileiras foi construída durante o período do escravismo, reatualizado após a abolição e ainda hoje é fruto de uma sociedade cuja lógica de dominação se assenta na construção de uma alteridade inventada para o negro, caracterizando-o como o outro "selvagem”, "bárbaro", “inferior”, o que popularmente pode ser resumido no termo "coisa ruim".

Em função desse "outro", tido como "coisa ruim", constituiu-se a imagem de um "outro" representante de "coisas boas", o branco. Enquanto o negro é identificado ao demoníaco, 
reserva-se ao branco a pureza e santidade (Santos, 2014). Se o negro é "coisa ruim", por conseguinte tudo que advém dele recebe essa mesma síntese, sua dança ${ }^{80}$, sua música, sua religião etc.

Odara: [...] A gente percebe que o preconceito com relação às religiões de matrizes africanas. É preconceito por ser religião de negro, porque para ofender: "Ah, essa pessoa parece um Oxum", mas para elogiar: "Parece um Deus Grego".

Muraguili: Porque Oxum é negro.

A desumanização, inferiorização e demonização do negro e, por conseguinte, de seus valores culturais (o que inclui sua religião) constituiu em técnica utilizada pelo branco opressor para justificar a escravidão. Pois, de que outro modo o homem branco, cristão, iria justificar a escravização de outros seres humanos, senão demonizando e destituindo de humanidade? Foi necessário demonizar o negro, associar sua cor de pele à cor do Diabo, a fim de manter o dualismo branco e negro e seus efeitos sociais. As falsificações e distorções de valores, sobrevivem até hoje no imaginário social, fazendo com que o mesmo preconceito que se volta contra os negros, recaia volte contra as religiões de matrizes africanas.

Dudu: É necessário desmistificar muitas coisas que foram demonizadas ao longo da história no nosso país. Ainda hoje nos deparamos com preconceitos fomentados por falta de conhecimento. A palavra já fala por si só: pré-conceito. Uma ideia anterior ao conhecimento. Ora, como posso conceber uma ideia acerca daquilo que ainda não conheço. É necessário dissecar as religiões afro-brasileiras e trazer à luz o que, de fato, ela é.

Como resgatar valores culturais ou se afirmar perante uma identidade negra ou quilombola que pode estar sendo vista por alguns como algo demoníaco, em virtude de fanatismo religioso? A guerra contra as religiões de matriz africana constitui um entrave à identidade quilombola e à identidade negra porque produz uma rejeição à toda uma simbologia e cultura que foram preservadas a duras penas pela comunidade negra ao longo de gerações e que se revestiram sob a égide do sagrado.

Além disso, muitos dos entrevistados, tal como Dudu, consideram as religiões afrobrasileiras parte importante para se entender a história da população negra no Brasil, por configurar um repositório cultural de extraordinária densidade. Sob esse viés, enfatiza Dudu:

\footnotetext{
${ }^{80}$ As danças africanas eram vistas pela elite branca brasileira como expressão da promiscuidade e prova de degenerescências moral e social. Ramos (2007) explica que dentro da "[...] organização social africana que é estabelecida pela religião, a dança é um dos elementos de conexão com o Cosmos. A dança tem um sentido de iniciação, expondo um saber incomunicável em termos absolutos, não reduzidos aos signos da língua falada ou escrita. O saber transmitido pela dança recompõe uma memória mítica fazendo o corpo vibrar ao ritmo do Cosmos, provocando no corpo uma abertura para o advento da divindade e se transforma, ele próprio, em metáfora da divindade. A dança, dentro dos valores africanos, está ligada a uma 'abertura' do corpo à divindade". (RAMOS, 2007, p. 111).
} 
Pesquisadora: Que associação você faz entre religiões de matriz africana e afrobrasileira e resistência a autoidentificação como quilombola?

Dudu: Hoje, essas coisas estão dissociadas. Pertencer a religiões de matriz africana não significa ser quilombola. Muito menos ser quilombola significa pertencer à religiões Afro-brasileiras. Contudo, há uma questão de construção de identidade ligada intimamente à questões históricas e culturais.

As religiões afro-brasileiras envolvem conteúdos culturais e históricos importantes ao entendimento da trajetória da história de resistência negra no Brasil. Com a escravidão, a população negra foi submetida a uma diáspora, o que acarretou a extraordinária violência do desenraizamento e do desterro, tornando árdua, algumas vezes impossível, a subsistência de estruturas culturais nativas de várias etnias africanas. A religião foi meio através do qual os valores civilizatórios negros puderam ser reconstituídos no continente americano. Segundo Luz (1983, p. 28), as “[...] religiões negras se caracterizaram como estruturas que mantêm revitalizado o processo civilizatório negro, marcando substancialmente a presença da África nesse continente".

Essas estruturas, sobretudo familiares, não puderam ser originalmente reconstituídas por homens e mulheres que provinham do tráfico negreiro, mas foram mantidas como referências por eles e seus descendentes, ainda que sob nova roupagem, posto que tiveram que se adaptar à realidade que encontraram nas Américas: os valores patriarcais, a violência opressiva imposta ao trabalho, o regime de latifúndio monocultor, a sociedade fortemente hierarquizada. A religião africana não pôde reconstituir a comunidade aldeã, mas “[...] suscitou grupos originais, ao mesmo tempo semelhantes e, todavia, diversos dos agrupamentos africanos" (BASTIDE, 1971, p. 32). Esses agrupamentos ou "nichos", segundo o autor, eram meios constituídos como forma de domesticação e controle pelo branco colonizador e pela Igreja Católica. Todavia, o africano soube deles se utilizar, modificando-os em conformidade com suas necessidades religiosas e sociais, fazendo deles espaços de resistência.

Como exemplo desses agrupamentos, o autor cita os batuques, as confrarias do homem de cor, as organizações do negro de ganho (cantos), as "nações" (irmandades), as reuniões de dança, as domingueiras (festas) nas zonas rurais. Ainda que essas festas se dessem em homenagem a santos católicos, eram utilizadas pelos escravizados para comungar e renovar seus valores e símbolos africanos:

[...] diante do modesto altar católico erigido contra o muro da senzala, à luz tremula das velas os negros podiam dançar impunimente suas danças religiosas tribais. $\mathrm{O}$ branco imaginava que eles dançavam em homenagem à Virgem ou aos santos; na realidade, a Virgem e os santos não passavam de disfarces e os passos dos bailados rituais cujo significado escapava aos senhores, traçavam sobre o chão de terra batida os mitos dos orixás ou dos voduns... A música dos tambores abolia as distâncias, enchia a superfície dos oceanos, fazia reviver um momento a África e permitia, numa 
exaltação ao mesmo tempo frenética e regulada, a comunhão dos homens numa mesma consciência coletiva (BASTIDE, 1971, p. 72).

Segundo Luz (1983), esse processo de associação simbólica entre santos e orixás foi um modo que o negro encontrou para superar a repressão religiosa e catequética, e serviu à implantação e à dinamização da religião africana nas Américas. Percebemos em nossa pesquisa que essa história se mantém viva. Isso transparece na fala de Muraguili, que pertence à religião do Candomblé. Esse trecho da narrativa se deu no momento em que Dudu e Odara relatavam que haviam pesquisado, em um site sobre religião africana, uma imagem em que Iemanjá era representada como uma mulher branca. Ela tenta dar uma explicação para o fato:

\footnotetext{
Muraguili: Mas eu acho que isso também é porque os negros naquela época por ter a religião... Porque tem essa coisa de...Santa Barbara é Iansã do Candomblé e no caso do Santo Antônio é Ogum, entendeu? Isso foi uma forma que os negros criaram de mascarar a verdadeira religião, entendeu? E os escravos naquela época adoravam Ogum dizendo que estava adorando Santo Antônio, isso porque naquela época eram os santos da Igreja Católica.

Dudu: E até mortos eles eram se descobrissem.

Pesquisadora: Era uma forma de fazer o culto...

Muraguili: ...De uma forma camuflada. E de certa forma isso continuou, entendeu? Então, todo mundo pensa que um Orixá é branco por causa dessas coisas de santo. Porque a maioria dos santos católicos são brancos, eu nunca vi um santo católico negro.
}

A camuflagem e o mascaramento das divindades ancestrais, ou seja, a associação simbólica entre santos e orixás não deve ser entendida como "sincretismo", visto que "[...] "as imagens católicas constituem-se em simples variáveis conjunturais que em nada alteram a estrutura simbólica sincrônica negra" (LUZ, 1983, p. 37).

As representações coletivas que os africanos traziam consigo haviam sido concebidas dentro de uma lógica cultural incompatível com a lógica ocidental. Dessa forma, os negros deram uma nova orientação às representações coletivas africanas, para que os valores místicos, presentes em seu universo simbólico-cultural pudessem, de certa forma, ter sentido e lhes ser útil diante da realidade enfrentada.

[...] Ogum deixará de ser patrono dos ferreiros ou o protetor dos instrumentos agrícolas de ferro, Exu não manterá, senão dificilmente, seu caráter de divindade da ordem cósmica para ocupar antes de tudo a regência da ordem social, mais exatamente, para lutar contra a desordem de uma sociedade de exploração racial. $\mathrm{O}$ tã-tã que se elevará nas noites sufocantes não será destinado a pedir chuva, a prosperidade da aldeia, a grandeza da tribo, mas chamará outros mistérios para o preparo de filtros de amor que permitirão as belas mulheres negras desforrarem-se do desprezo das patroas brancas, tomando o coração de seus maridos [...] ou o preparo de venenos poderosos que enfraqueciam o cérebro dos senhores, fazendo-os cair em inanição e morrer lentamente [...] (BASTIDE, 1971, p. 97). 
As associações simbólicas entre orixás e santos eram necessárias, visto que as religiões africanas eram proibidas e perseguidas. Segundo Prandi (2003), mesmo após o advento da República, momento em que o catolicismo deixa de ser religião oficial, as opressões continuaram, como lembra Dudu:

\begin{abstract}
Então, eu estava explicando isso, se pararmos e observarmos que a escravidão foi abolida há cento e poucos anos, vamos dizer que foi um longo passo até aqui, mas que há, em contrapartida, um caminho inteiro para ser trilhado. Demos um longo passo, mas o caminho a ser trilhado ainda é enorme, gigantesco à frente. Mas observando, assim, houve muitas mudanças. Como foi o caso que ela falou que escondia e tal... Depois quando houve o surgimento da República os cultos foram permitidos só que dentro de casa, escondidos. Você tinha que se esconder para fazer aquilo, você não poderia chegar assim: "Ah vou...". "Vai para onde fulano?" "Vou ali no terreiro". Não podia.
\end{abstract}

O período da República foi marcado por projetos de modernidade e urbanização da sociedade brasileira empreendidos pela elite branca com o intuito de transformar as cidades brasileiras à imagem e semelhança de cidades europeias (KOGURUMA, 2001). Para alcançar esse ideal, a elite brasileira considerava imprescindível se livrar de um elemento indelével, incompatível com o ideal de brancura que se buscava atingir - o negro. Dessa forma, as ações implementadas foram direcionadas na tentativa de expurgar o negro ou, ao menos, dissimular sua existência. Isso ocorre no chamado processo de branqueamento, nas políticas públicas que tinham como respaldo - naquilo que posteriormente foi chamado de pseudo-ciência, a eugenia.

Era necessário difamar o negro, estigmatizar seu modo de vida, sua cultura, suas crenças e práticas religiosas. Assim, as perseguições às religiões afro-brasileiras não apenas continuaram, como foram intensificadas, "[...] efetuaram-se perseguições policiais contra lideres messiânicos, curandeiros e feiticeiros [...] clamava-se contra a crescente popularização dos candomblés nos artigos de jornais". (KOGURUMA, 2001, p. 75).

Por conseguinte, dizer-se e comportar-se como católico era, e ainda continua a ser, uma forma de se "camuflar" - como disse Muraguili em seu depoimento - e, assim, não sofrer com as perseguições e preconceitos:

[...] mesmo atualmente, quando a liberdade de escolha religiosa já faz parte da vida brasileira, muitos seguidores das religiões afro-brasileiras ainda se declararem católicos, embora sempre haja uma boa parte que declara seguir a religião afrobrasileira que de fato professa. Isso faz com que as religiões afro-brasileiras apareçam subestimadas nos censos, em que o quesito religião só pode ser pesquisado de modo superficial. Com o tempo, as religiões afro-brasileiras tradicionais se espalharam pelo Brasil todo, passando por muitas inovações, mas quanto mais tradicionais os redutos pesquisados, mais os afro-brasileiros continuam se declarando, e se sentindo, católicos. Mais perto da tradição, mais católico. Um mapeamento dos afro-brasileiros segundo as diferentes regiões mostra isso muito bem: eles são em número relativamente pequeno no Nordeste, região em que a religião afro-brasileira tradicional se formou, o que pode parecer paradoxal, e em número bem maior nas regiões em que se instalou mais recentemente, ou seja, já no século XX, e onde a 
mudança religiosa no campo afro-brasileiro tem se mostrado mais vigorosa, casos do Sudeste e do Sul. Até hoje o catolicismo é uma máscara usada pelas religiões afrobrasileiras, máscara que evidentemente as esconde também dos recenseamentos. (PRANDI, 2003, p. 17).

A religião se configurou em meio através do qual a população negra empreendeu sua luta de resistência ao longo do processo histórico, posto que através dela se formaram espaços de conservação e transmissão de valores culturais entre africanos e afro-brasileiros. No Brasil, os negros desenvolveram uma dinâmica religiosa capaz de aglutinar e manter um grupo coeso e organizado politicamente. Segundo Wissenbach (não datado, não paginado), para africanos e afro-brasileiros, as práticas religiosas e os vínculos que tinham por base as religiões afrobrasileiras constituíam vias de recuperar a "[...] humanidade lesada pelas sucessivas compras e vendas e pela reificação imposta pela escravização, [...] e, como tais, veículos de inserção social na reorganização da vida em liberdade, importantes sobretudo na época final da escravidão".

Como sabemos, a diversidade das estruturas familiares encontradas na África estavam ligadas a clãs e a linhagens familiares relacionadas à ancestralidade e, no Brasil, ainda que essas estruturas tenham sido destruídas pela escravidão, atitudes mentais e comportamentos ligados à cultura dos antepassados permaneceram entre os descendentes de africanos (BASTIDE, 1971). A partir de Slenes (1999), podemos dizer que isso foi possível porque haviam signos comuns, elementos de homogeneidade advindos de uma herança cultural compartilhada, de origem centro-africana, que eram cultivados e mobilizados a favor da construção de laços entre os escravizados.

[...] Na África, o culto dos ancestrais está vinculado, portanto, à fundação de um território, à coesão, organização e expansão da família, da sociedade e da nação. No Brasil, a família extensiva africana, de um modo geral, deu lugar às irmandades religiosas, onde a referência à nação dos ancestrais congrega os fiéis e adeptos da seita, propiciando fortes vínculos sociais, substituição a referência parental. (LUZ, 1983, p. 36).

Compreende-se que religiosidade e ancestralidade estão inter-relacionadas e ambas vinculadas ao modo de vida e ao território. Através das observações de Bastide (1971) e de Luz (1983) é possível notar que a dimensão ancestral que define e regula a estrutura e as relações nas sociedades africanas pode ser encontrada nas religiões de matriz africana.

$\mathrm{Na}$ África, cada divindade, seja Xangô, Omolu ou Oxum, tem seus sacerdotes especializados, suas confrarias, seus conventos, seus locais de culto. No Brasil, mesmo nas cidades "negras" do litoral, era impossível para cada "nação", bem menos numerosa, reencontrar e reviver esta especialização. As seitas vão, pois, tornar-se reduzida imagem da totalidade do país perdido; quer dizer, cada candomblé terá, sob a autoridade de um único sacerdote, o dever de render homenagens a todas as divindades ao mesmo tempo e sem exceção. Em lugar de confrarias especializadas, uma para Oxum, outra para Xangô e outra para Omolu, teremos apenas uma confraria 
[...]. Por conseguinte, temos a concentração da África na seita (BASTIDE, 1971, p. 90).

No Candomblé ocorre a "recriação" de laços familiares, possibilitando aos afrodescendentes reconstruírem vínculos de identidade fragilizados pela escravidão. Os terreiros tornam-se espaços de resistências cultural e política, na medida em que em seu interior é possível encontrar forte relação com a dimensão ancestral e a recomposição simbólica da família extensiva africana, através da "família de santo".

[...] um novo parentesco se constrói: o parentesco religioso (pai de santo, mãe de santo, irmã de santo). Esta reconstituição de vínculos de pertença permitiu uma reconexão com a ancestralidade, através do culto e do compartilhamento de vivências passadas, fornecendo o estabelecimento de uma memória coletiva compartilhada. (SANTOS, 2014, p. 45)

A população negra teve que se reinventar, ressignificar e adaptar suas crenças e práticas religiosas, de maneira a enfrentar as profundas transformações advindas do fim da escravidão e advento da República. No Candomblé, por exemplo, após a abolição, praticantes articularam um movimento de "retorno à África", que se traduziu na busca de união de todas as seitas africanas em uma federação (BASTIDE, 1971). Esse fato demostra que a população negra estava atenta às transformações e a seus efeitos, como o enfraquecimento de sua ligação com a África e o risco à manutenção e transmissão de suas tradições.

O fim do tráfico negreiro reduziu o número de africanos introduzidos no Brasil e, consequentemente, a entrada de líderes religiosos africanos de "nações" diversas que pudessem renovar o vínculo com os ancestrais. Além disso, uma maior aproximação dos mecanismos sociais do mundo urbano e branco, que prometia ascensão social em troca da adesão pelo embranquecimento, poderia implicar no afastamento das novas gerações dos valores tradicionais, tornando cada vez mais difícil sua transmissão.

Percebendo as dificuldades que tais mudanças poderiam ocasionar a suas práticas religiosas e culturais, a população negra atuou ativamente e, de modo a se fortalecer, se agarrou a elas com muito mais força, a fim de se reconhecer nelas e através delas. E o fez, em meio à sua transmutação de escravizado para homem livre, como havia feito quando se viu em condição de escravidão.

É certo que o modo de vida, visão de mundo do negro, era contrário ao mundo do branco, não somente por questão de cultura, mas também pela própria condição social cujos mecanismos mantinham a dualidade racial negro/branco, ou a regra de hierarquização racial menos negro/ mais branco (dado à miscigenação). A situação social de desigualdade em que a maior parte da população negra se encontrava no pós-abolição não foi aceita pacificamente, 
assim como se pode observar no contexto contemporâneo. Um olhar para as práticas religiosas afro-brasileiras ajuda a compreender o processo histórico de resistências política e cultural do povo negro. Conforme Koguruma (2001, p. 31), “[...] o desdobrar histórico das religiosidades afro-brasileiras permeou e permeia as diversas 'estratégias' e 'artimanhas' de sobrevivência de um grande número de indivíduos".

Nessa perspectiva, seja em microespaço, em uma comunidade quilombola, ou no macroespaço da sociedade brasileira, a abordagem sobre religiões de matriz africana precisa ser feita, posto que seus elementos socioculturais possibilitam “[...] reflexão sobre a existência de sistemas de conhecimento, formas de pensar, experiências vividas, ritmos sociais e temporalidades cujos aspectos se afastam dos componentes inerentes à racionalidade e à lógica do sistema capitalista [...]"81. A religião afro-brasileira não se resume a crenças e práticas, ela é história, cultura, ancestralidade, resistência, formas de pensamento. E tudo isso perpassa nossa identidade, embora o preconceito e o racismo cotidianos nos impeçam de reconhecer o que há de "tudo isso" em nós, colocando-nos sob o julgo de uma escravidão mental que constantemente leva à desumanização do outro e de nós mesmos.

Logo, o diálogo com as referências de matriz africana e matriz afro-brasileira é imprescindível para que possamos emancipar nossa mente, reconhecer que se pode trilhar novos caminhos, descobrir novas singularidades, modificar e criar opções, fazer raiz, ser raiz, se libertando da lógica dominante que faz prevalecer uma única raiz (eurocêntrica), cujas ramificações se traduzem em múltiplas opções que desembocam sempre no mesmo destino.

\subsection{Identidade, corpo e ato político}

As identidades são construídas mediante marcadores culturais, sociais, políticos, presentes no meio social. Esses marcadores são estabelecidos por meio de representações sociais hegemônicas que determinam lugares sociais para os sujeitos a partir de "marcas" relativas ao gênero, à "raça", classe e sexualidade (LOURO, 2000; BRAH, 2006). Tais representações fundamentam-se no elemento mais visível e primordial através do qual nos apresentamos para o mundo: o corpo. Em uma sociedade cujo padrão de "normalidade" é ser branco, heterossexual e cristão, aprisionar em estereótipos e estigmas indivíduos cujos corpos não correspondem a esse padrão, destinando a eles um lugar abjeto dentro da estrutura social, é um dos desígnios do poder para manutenção das desigualdades sociais.

${ }^{81}$ Ibid., p. 31. 
Desse modo, podemos dizer que há uma "identidade" forjada socialmente que antecede o sujeito, inscrita no corpo, de forma que, taxativamente, diz quem ele é, antes que ele próprio possa ser capaz de dizê-lo e diz qual é seu lugar dentro da sociedade, antes que ele possa compreender o que é ter um lugar. Essa marca do corpo é, no entanto, um produto histórico e imaginário. Sociedades que tinham escravos, como Roma na Antiguidade, não marcavam a instituição da escravidão no corpo dos escravizados - homens livres e escravizados podiam ser indiferentemente aquilo que chamamos hoje de negros e brancos. A palavra "escravo" era derivada do latim "slavus", que significava "eslavo" (COSTA E SILVA, 2011).

$\mathrm{Na}$ sociedade brasileira, o corpo negro é falado intensamente no meio social, atribuído de um sistema de valores negativos que, ao serem internalizados, impregnam as identidades dos sujeitos sociais, formando uma subjetividade forjada pelo racismo. Essa subjetividade racista fundamenta-se no binarismo negro/branco, que constitui limites às identidades de ambos, o primeiro circunscrito negativamente e o segundo positivamente.

A construção da identidade não pode ser dissociada do mundo que nos rodeia, pois a formação da autoimagem ocorre com base na relação de alteridade.

Isso implica o reconhecimento radicalmente perturbador de que é apenas por meio da relação com o Outro, da relação com aquilo que não é, com precisamente aquilo que falta, com aquilo que tem sido chamado de seu exterior constitutivo, que o significado "positivo" de qualquer termo - e assim, sua identidade - pode ser construído (HALL, 2000, p. 110, itálico do autor).

No caso da pessoa negra, as representações negativas a respeito de seu corpo podem levá-la a se autorreconhecer na imagem deturpada e negativa com a qual se defronta em seu contato com o outro, no meio social. Desde a mais tenra idade, a pessoa negra está à mercê de preconceitos e estereótipos negativos sobre sua inscrição racial.

Dudu: Quando criança eu não gostava não. Porque o povo dizia assim: “Ah negro do beição". Eu ficava com muita raiva, sabe? Eu não queria ser negro não....

Oré: Injuria racial.

Muraguili: Eu assisti um vídeo na internet que era bem assim... Meninos negros...crianças negras...

Odara: Eu vi isso...

Muraguili: Botaram duas bonecas, uma branca e outra negra "Qual é a mais bonita?". Aí falaram: "A branca". "Qual é a má?" "A negra". E você se parece com qual?”. Aí ela mostrava: "A negra”. A criança ficava tipo assim, sabe? ...Com aquele choque. E falou que tudo que tinha de ruim era a negra... "Ah, porque a branca é mais bonita que a outra?". "Porque ela é branca, tem os olhos azuis e tem cabelo bom". Aí no final da entrevista perguntaram para cada criança: "E você se parece com quem?”. Aí ela mostrava a negra, entendeu? Acho que isso deve ser horrível para uma criança...

Dudu: É que o preconceito está intrínseco nela. Inerente a ela. Ela não percebe que ela repassa aquilo, né?

Odara: E tipo, isso está em tudo, a religião do preto é a religião que não presta, o cabelo preto é o cabelo ruim, a cor do preto é a cor feia, quanto mais claro mais bonito. 
Segundo Glass (2012), desde os primeiros anos de vida, as crianças conseguem entender a ordem racial presente em uma sociedade, sendo capazes de notar "[...] as diferenças na cor de pele, nas características faciais, no comprimento, estilo e textura de cabelo [...]". "Elas conseguem também classificar pessoas em termos de "raça" e hierarquia de classes [...]" (GLASS, 2012, p. 892). Nesse sentido, crianças negras percebem o posicionamento subordinado que a sociedade lhe atribui, evidenciaram Muraguili e Dudu. A partir do momento em que a criança negra toma consciência do racismo, ela pode desenvolver uma relação persecutória com relação ao corpo (COSTA, 2003). Em sua narrativa, Dudu diz que sua negação do corpo transcorreu a infância e perpassou sua adolescência.

A identidade se estabelece a partir da relação com o nosso corpo, é com ele que experienciamos o mundo, assim “[...] a imagem ou o enunciado que o sujeito tem de si estão baseados na experiência de dor, prazer ou desprazer que o corpo lhe obriga a sentir e a pensar" (COSTA, 2003, p. 141). Por ter seu corpo rejeitado socialmente, a pessoa negra pode não encontrar nele prazer, ao contrário, pode passar a senti-lo como uma ferida, como algo que lhe infringe sofrimento. Nota-se que Dudu, devido às ofensas sofridas com relação a seu corpo, passa a vê-lo como culpado e acaba por desenvolver um sentimento de raiva, principalmente com relação à sua cor: "Pensava assim: 'Ô, porque eu fui ter essas características de negro?' Aí foi o momento que eu comecei a sentir raiva da minha cor. Sentia raiva...".

O "ser negro" corresponde a uma categoria incluída num código social, que se
expressa dentro de um campo etno-semântico onde o significante "cor negra" encerra
vários significados. O signo "negro" remete não só a posições sociais inferiores, mas
também a características biológicas supostamente aquém do valor das propriedades
biológicas atribuídas aos brancos. Não se trata, está claro, de significados
explicitamente assumidos, mas de sentidos presentes, restos de um processo histórico
ideológico que persistem numa zona de associações possíveis e que podem, a qualquer
momento, emergir de forma explícita. Se o que constitui o sujeito é o olhar do outro,
como fica o negro que se confronta com o olhar do outro que mostra reconhecer nele
o significado que a pele negra traz enquanto significante? (NOGUEIRA, 1998, p. 90).

Desse modo, segundo Nogueira (1998), na busca de livrar-se de todos os significados relativos à "cor" (significante), resta ao negro recusá-la, o que se dá por meio da negação do próprio corpo e, consequentemente, de si mesmo. A sociedade racista oferece um espelho cujo reflexo ideal já está dado. Cabe ao indivíduo a comparação entre sua real imagem e a imagem fictícia imposta socialmente como ideal. Nesse sentido, a pessoa negra, ao perceber que seu corpo “[...] se opõe à construção da identidade branca que ele foi coagido a desejar" (COSTA, 2003, p. 141), vê-se frente a um dilema: como tornar-se o outro do espelho?

Todos aqueles que nascem desse lado, que são negros, nascem num grande exílio. Um enorme exílio forçado. E, a partir daí, vêm todos os outros exílios que procedem dele e que criam outros novos lugares de exílio. Eu logo percebi que não tinha conexão 
com o mundo, fora uma conexão fictícia que o mundo branco me forçava a aceitar, a querer ser como eles. Aí já se criava um corte fundamental, que era o corte comigo. Eu não sabia quem eu era, porque eu queria ser outro. Porque esse outro é que era o bom, o bonito, o que todo mundo queria (MOORE, 2015)

O relato de Carlos Moore, assim como a narrativa de Dudu, são exemplos do quão o processo de construção da identidade negra - em uma ordem racial que coloca o negro em condição de exílio existencial e impele à alienação de sua humanidade - é doloroso e marcado por um intenso conflito com o corpo. Pois seu corpo diz que não pode ser o outro do espelho e que, por conseguinte, não pode se encaixar no mundo regido por uma ordem racial que diz: "Não há espaço para o corpo negro em um "mundo branco"”. E, assim, o sujeito passa a vivenciar um sentimento de falta que lhe parece eterno.

[...]. Normalmente as pessoas sabem o que são, elas são o que são, não se colocam a questão. Mas eu não sabia, eu não queria ser o que eu era e, pelo fato de não querer ser aquilo, não sabia o que eu era. Você se sente constantemente num estado de falta [a voz de Moore fica instável]. Não tenho a pele correta, não tenho o nariz correto, não tenho os lábios corretos, não tenho o corpo correto, não tenho. Tudo é falta" (MOORE, 2015; acréscimo da entrevistadora).

Na construção da identidade o "outro" tem, portanto, o significado daquilo que "falta". Entretanto, nesse caso, a falta não está no sentido positivo: reconheço no outro algo que não possuo e, por meio da diferença, sei dizer quem sou e quem é o outro reconhecendo, assim, minha singularidade. A falta tem aqui um sentido negativo: vejo-me forçado a reconhecer-me como diferente em termos de inferioridade com relação ao outro, branco, porque a sociedade diz que minha diferença com relação a ele não me permite ser reconhecido como ser humano. Assim, o sujeito se vê imerso no desejo de ser algo que não é, ou de ter o que não possui, constituindo-se em sujeito da falta.

Por que aqui, a diferença não abriga qualquer vestígio de neutralidade e se define em relação ao outro, o branco, proprietário exclusivo do lugar de referência, a partir do qual o negro será definido e se autodefinirá. Assim é que para afirmar-se ou para negar-se, o negro toma o branco como referência. A espontaneidade lhe é um direito negado, não lhe cabe simplesmente ser (SOUZA, 1983, p. 26-27).

Segundo Costa (2003, p. 145), o “[...] sujeito negro diante da "ferida" que é representação de sua imagem corporal, tenta, sobretudo, cicatrizar o que sangra". Percebendo que o corpo é incompatível com o ideal proposto, passa a negá-lo, ou envereda para a tentativa de adequá-lo a esse padrão. A mesma ideologia racial que o fez rejeitar o corpo, apresenta a ele uma saída, o embranquecimento.

A autonegação identitária nada mais é do que a tentativa de se distanciar de um "ser negro" inventado pela lógica racista, cujas características são relativas ao inóspito. Dentro dessa 
lógica, o estigma da cor abrange todos os atributos físicos do corpo negro: formato do nariz, lábios, cabelos. Nesse sentido, a "[...] ideologia de cor é, na verdade, a superfície de uma ideologia mais daninha, a ideologia do corpo" (COSTA, 2003, p. 140, itálico do autor).

Dudu: Minha mãe fala: "Eu sou negra, negra dos lábios grossos". Meus lábios são herança genética dela, né? Ela fala assim: "Eu sou negra dos lábios grossos, não tem quem tira isso de mim". Minha avó também tinha isso, então foi passando, né? Ela falava assim: "Eu sou negra, eu sou preta mesmo". Aí, quando chegava alguém em casa: "Você é preto". "Não, eu não sou preto não. Sou marrom". Ela dizia assim: "Você é negro, você é preto, assim como eu".

Odara: Eu falo isso sempre com o Dudu porque ele fala que existe racismo reverso sim. Como eu falo com ele também, eu não acredito que a pessoa negra é racista, ela reproduz o racismo, ela é a vítima da história.

Dudu: Então, ela faz sem perceber. Poucas famílias têm essa informação e formação. Minha mãe se preocupou porque ela observava como a minha avó era tratada. Minha avó era doméstica, era praticante da religião e usava isso também para criar muitos negros da família, e também era empregada doméstica. E a minha mãe via como minha avó era tratada. Então, a partir desse momento, ela passou a observar, porque a minha avó era negra e às vezes ela era humilhada, entendeu? Então, a minha mãe observava muito isso. E até a minha avó mesmo ela reproduzia esse preconceito, ela gostava de se relacionar com pessoas brancas. É tanto que eu tenho uma tia que é tão branca, que eu cobrava da minha mãe: "Vocês são irmãs? Ah não, vocês só podem ser irmãs de parte de mãe ou de pai só". Porque ela também reproduzia isso. Ela queria entrar... a gente fala muito disso... a minha avó queria entrar naqueles padrões. O pai era assim, da cor de Odara... Ele era branco dos olhos verdes. E a minha mãe foi e nasceu negra dos olhos verdes. Então, ele tinha aquela coisa... Eu acho que o pai dele era negro e a mãe era branca. Mas ela dizia: "Ah, eu quero me relacionar com os brancos". Não pela preferência, porque às vezes a pessoa tem aquela preferência, sabe? Mas pelo fato de que ela não queria negro. Ela não gostava de negro. Ela tinha aquela coisa: "Negro não. Não pode ser negro".

Costa (2003) assinala que a pessoa negra guiada pelo ideal de branqueamento tem suas atitudes mentais e práticas orientandas no sentido de fazer seu corpo desaparecer. Assim, é levada a ver na miscigenação uma alternativa para aniquilar sinais de cor nas futuras gerações familiares. Em seu depoimento, Dudu mostra que essa foi uma estratégia utilizada por sua avó. Ele entende que a "preferência" da avó de se relacionar afetivamente com parceiros brancos ia além do sentimento afetivo, pois correspondia à tentativa de se enquadrar no padrão social. Segundo o autor, "[...] o pensamento do sujeito negro, parasitado pelo racismo, termina por fazer do prazer um elemento secundário na vida do corpo e da mente (COSTA, 2003, p. 142)".

A negação racista pode atingir o corpo de um outro negro (a), negro (a) que poderia ocupar o lugar de objeto de amor. A tentativa de branquear pode levar à substituição da escolha baseada no afeto por uma repetição histórica de desejo de embranquecimento das futuras gerações e de valorização pessoal através do relacionamento com alguém racialmente "superior" (SANTOS, 2014, p. 104).

A "preferência" da avó parece não se restringir apenas ao desejo de ter parceiros brancos, mas tem um sentido mais abrangente: "Ah, eu quero me relacionar com os brancos". Em entrevista, Dudu não menciona explicitamente o conflito da avó com relação a seu corpo 
negro, porém é possível apreender que ela não tinha uma afirmação positiva de identidade e que sua atitude era efeito da internalização da mitificação social do negro (irracional, feio, sujo) e do branco (bom, justo, belo). Sua postura corresponde à busca do embranquecimento físico e social através, respectivamente, da miscigenação e do distanciamento do estereótipo de comportamentos atribuídos ao negro.

Costa (2003, p. 139) enfatiza que a "[...] brancura detém o olhar do negro antes que ele penetre a falha do branco". Dessa forma, segundo o autor, não importa o branco, importa a brancura, da qual ele é legítimo portador, mas que, no entanto, o transcende. A brancura se apresenta à consciência negra como imaculada, como sinônimo de nobreza estética, sabedoria, moral, cultura, civilidade e humanidade, em contraposição ao "arquétipo de valores inferiores representado pelo negro" (FANON, 2008, p. 160), associado ao mal, ao feio, ao pecado, à sujeira (física ou moral), à morte, à fome, à miséria. Estes estereótipos não são somente relativos à estética, mas também a aspectos culturais, como a religião, conforme lembra Odara. Nesse contexto, a pessoa negra é forçada a tomar o modelo branco como única possibilidade de integrar-se socialmente, de ser reconhecido e humanizar-se (SOUZA, 1983).

No momento em que Dudu faz a análise da autonegação identitária da pessoa negra e da negação do seu igual, como ocorreu com a sua avó, ele cai em uma das artimanhas do racismo: entender uma consequência do racismo (a autonegação) como o racismo em si. Depois de Odara contrapor-se à sua forma de ver as coisas, Dudu chama atenção para a falta de consciência na reprodução do racismo: "Então, ela [pessoa negra] faz sem perceber”. Todavia, em outros momentos do grupo - o que será discutido em parte posterior desse trabalho - ele associa a autonegação e a negação de uma outra pessoa negra à internalização do ideal do branqueamento e às humilhações sociais vivenciadas. As contradições em suas narrativas são significativas daquelas a que todos estamos sujeitos, diante das questões tão ambíguas que o racismo coloca:

O racismo é uma ideologia. A ideologia só pode ser reproduzida se as próprias vítimas
aceitam, a introjetam, naturalizam essa ideologia. Além das próprias vítimas, outros
cidadãos também, que discriminam e acham que são superiores aos outros, que têm
direito de ocupar os melhores lugares na sociedade. Se não reunir essas duas
condições, o racismo não pode ser reproduzido como ideologia, mas toda educação
que nós recebemos é para poder reproduzi-la. Há negros que introduziram isso, que
alienaram sua humanidade, que acham que são mesmo inferiores e o branco tem todo
o direito de ocupar os postos de comando. Como também tem os brancos que
introjetaram isso e acham mesmo que são superiores por natureza. (MUNANGA,
2012a, não paginado).

Como diz Munanga (2012a), o racismo enquanto ideologia é internalizado e reproduzido por negros e brancos. A autonegação de si e do seu igual não pode ser tomada 
como racismo, mas como comportamento decorrente da violência racista. Da mesma forma, não se pode falar em "racismo reverso", ou seja, de um racismo anti branco por parte dos negros, pois, como nos diz Moore (2012), o racismo é um sistema de opressão e envolve relação de poder. Vale precisar que o termo "racismo reverso" é utilizado pelos depoentes para se referir à ideia de "racismo do negro para si mesmo ou para outro negro", enquanto costuma ser utilizado por discursos que alegam haver racismo de "negro para branco". O grupo dominante é que perpetua a estigmatização do negro para, em contrapartida, manter seus privilégios.

A estigmatização consiste em atribuir anomalia ao grupo a ser estigmatizado, a fim de que sua situação social, imposta pelo grupo dominante, seja interpretada como decorrente de deformidades naturais. A condição de subalternidade social é explicada pelo discurso de uma inferioridade inata. Utiliza-se o racismo para transformar o "parecer" (diferenças culturais e físicas) em "ser", construindo um retrato mítico (estereótipos, desqualificações) que ateste a inferioridade das pessoas negras.

Um dos mecanismos do racismo, afirma Memmi (1977), é a substantificação, em proveito do acusador, de um traço real ou imaginário do acusado. Compreende-se que o estigma, marca que identifica o grupo a ser estigmatizado, é sempre fantasioso, ainda que esteja relacionado a traços físicos, reais ou imaginários (ELIAS; SCOTSON, 2000 apud GUIMARÃES, 2008) $)^{82}$. O estigma social está ancorado em uma série de estereótipos relativos ao "ser negro" que configura a pessoa negra "[...] por una percepção e por um entendimento distorcidos da realidade". (CROCHÍK, 1996, p. 48).

É descabida a afirmação da existência do "racismo reverso", pois a estética branca não é estigmatizada. Os discursos sobre "racismo reverso" ou com o nome "racismo às avessas", são estratégias para transformar a vítima em culpada, naturalizar e banalizar a violência racista. O racismo é muito ardiloso, cria a ilusão do inato, posto que o corpo com o qual o indivíduo já nasce é estigmatizado; produz uma situação real de subalternidade e inferiorização da população negra, fazendo com que a representação social depreciativa do negro como “inferior", forjada por ele (o racismo), encontre no social algum tipo de "sentido". Além disso, sabemos que a autoimagem de uma pessoa se constitui com referência ao seu grupo social, de modo que as representações sociais negativas sobre seu grupo o penetram, o abatem, podendo desarmá-lo. Em contrapartida, o contexto familiar é “[...] onde se cuida de arar o caminho a ser percorrido, antes mesmo que o negro, ainda não sujeito, a não ser ao desejo do Outro, construa seu projeto de chegar lá" (SOUZA, 1983, p. 36).

${ }^{82}$ ELIAS, N; SCOTSON, J. Os estabelecidos e os outsiders. Rio de Janeiro: Zahar, 2000. 
Dudu foi exposto, no contexto familiar, à negação do "ser negro" pela avó, mas a afirmação do "ser negro" pela mãe. Enquanto sua avó buscava o embranquecimento, como meio de aplacar a humilhação, sua mãe exalta seus traços fenotípicos para afirmar sua identidade negra: "Sou negra dos lábios grossos". Entre a afirmação e a negação do "ser negro" no contexto familiar, as humilhações sofridas por Dudu no contexto social apenas confirmavam a "negatividade" do corpo negro. No entanto, a autoafirmação de sua mãe foi essencial para que ele viesse a construir um caminho de questionamento e encontrar uma saída para algo que lhe afligia.

Dudu: Eu comecei a me importar de fato, a ver isso, acho que tem uns cinco anos... quando eu li um poema de Castro Alves, Navio Negreiro. E eu tanto li como depois eu vi no Youtube a narração... E aquilo ali de certa forma me tocou e eu fiquei observando assim... aí eu pensei assim: "O que será que Deus pensou? O que será que Deus..." sabe? "Como Deus se sentiu quando viu os escravos sendo... os escravos não, os negros, sendo escravizados, sendo marginalizados? Quando viu a própria Igreja Católica, que era a representação máxima, entre aspas, de Deus na Terra, autorizar esse tipo de coisa?" E eu fiquei me perguntando assim: “O que será?" E a partir desse momento eu comecei a me importar. De forma assim as pessoas diziam: "Ah, não sei porque que isso e tal, mas eu vou deixar assim". Como que tudo isso aconteceu? Como é que se deu essa formação?

Pesquisadora: Onde você estudava nessa época?

Dudu: Eu estudava no IERB.

Pesquisadora: Você fez esse questionamento para a professora?

Dudu: Não, para mim mesmo. Eu fazia esse questionamento comigo mesmo. Como eu fui uma criança muito só, assim entre aspas.... Eu tinha essa mania de ficar pensando e tal... Aí, eu fui procurar mais acerca disso, sobre a cultura, fui ler um pouco mais. Aí, eu comecei a entender o que de fato era. Porque até então, eu era criança, era muito novo assim e eu só absorvia o que... era uma esponja. A sociedade estava falando negro é isso, negro é aquilo e eu estava absorvendo, absorvendo, absorvendo. Mas aí, depois que eu fui procurar... quando eu vi esse poema eu comecei a pensar assim: "Não, vou procurar para saber melhor". Aí, quanto mais eu procurava saber disso, mais eu via o quanto nós fomos assim... o quanto nós estávamos em detrimento ao longo do tempo, o quanto... tipo assim, nós íamos ajudar entre aspas, ajudar forçadamente, mas que, mesmo assim, nós saímos em detrimento. E eu comecei a observar, comecei a ver isso diferente. Realmente a sociedade ela nos... Nós somos, literalmente, entre aspas, nós somos o lixo da sociedade, é isso que ela acha. Que nós estamos aqui "Ah esse aí é o último lá embaixo, lá embaixinho", sabe?... Olha! Eu vou dizer assim a luz social é como se não tivesse alcançado a gente, como se ficássemos na penumbra social. Então, eu comecei a observar isso. Foi quando eu comecei a observar muito em bancos, como eu falei agora, observando assim... nas igrejas.... Em qualquer lugar que eu vou eu observo, eu saio daqui e observo: "Será que aqui tem algum negro trabalhando?" Vou olhar. "Será que aqui tratam o negro diferente? Será que aqui é dessa forma? Será que é assim ou assado?" Eu comecei a olhar e vi que em quase todas as esferas da sociedade tratam o negro assim como se fosse um lixo, como se ficasse na penumbra. Eles dão mais valor para as pessoas, às vezes, não é tanto pelo potencial intelectual, mas mais pelo potencial... potencial não, mais pela cor da pessoa.

Odara: Pela aparência.

O relato de Dudu nos revela quão complexo é o processo de construção da identidade negra, envolvendo descobertas, autodescobertas, construções, desconstruções, reconstruções, 
ressignificações e reconhecimento. Como explica Santos (2014), muito cedo a pessoa negra tem que se haver com situações racistas que acabam por se transformar em traumas pela incapacidade de elaboração da violência recebida. Dudu percorreu um longo caminho até poder elaborar todas as concepções pré-concebidas sobre "ser negro" absorvidas por ele do meio social:

\begin{abstract}
Reconhecer-se como negro é trabalho que exige grande sutura, um trabalho artesanal de reconstrução do eu, que passa por compreensões subjetivas e sociopolíticas. Processo que envolve a desconstrução de ideologias raciais, compreensão de processos históricos de dominação; bem como a elaboração psíquica dos traumas sofridos em razão dessa ideologia (SANTOS, 2014, p. 111).
\end{abstract}

Dudu busca objetivações histórico-sociais que pudessem explicar as condições de subalternidade social que acomete a população negra na atualidade. Ele inicia um processo de desconstrução do mito negro, percebe que essas condições têm uma razão histórica que resulta das discriminações e opressões do passado e derivam do racismo que se reatualiza nos dias atuais. Em outras palavras, ele observa que o efeito da violência racista atravessa gerações, relegando às gerações do presente as mesmas desvantagens de seus antepassados - um ciclo infernal que mantém, geração após geração, a população negra em situação de inclusão/integração social limitada ou, dito de outra forma, em condição de "penumbra social".

O conceito do ciclo vicioso de pobreza implica não apenas que crescer num estrato inferior afete as chances ocupacionais [e sociais] adversamente, mas, mais especificamente, que as várias condições associadas à baixa origem social se reforcem mutuamente e tenham efeitos adversos cumulativos nas oportunidades ocupacionais [e sociais] (BLAU; DUNCAN, 1967, p. 404 apud HASENBALG, 1979, p. 200) ${ }^{83}$.

Para Hasenbalg (1979) as péssimas condições de vida da população negra ao longo das gerações se mantêm mediante a transmissão e produção intrageracional da desigualdade social decorrente do racismo. Em razão das discriminações, as gerações presentes encontram-se em situação de desvantagem por terem origem em famílias de baixa posição social e por acumularem desvantagens em termos de recursos competitivos com relação aos brancos:

[...] em níveis de habilidade, educação e aspirações e a própria adscrição racial. [...] uma vez que uma geração nova ou coorte de idade inicia o ciclo de vida adulta, o racismo e a discriminação racial continuarão a interferir no processo de mobilidade intrageracional, de tal forma a restringir as realizações dos não-brancos, relativamente aos brancos da mesma origem social (HASENBALG, 1979, p. 208).

Além disso, tais discriminações aliadas aos estereótipos atingem a dignidade e autoestima da pessoa negra, podendo levá-la a formular uma autoimagem desfavorável de si

${ }^{83}$ BLAU; DUNCAN. The American occupational structure, 1967. 
mesma e, por conseguinte, limitar suas aspirações e motivações. O racismo impõe à pessoa negra uma dupla estigmatização (por ser pobre e por ser negro), que se traduz em dupla desvantagem em relação ao branco ${ }^{84}$ :

[...] Em termos de oportunidade de mobilidade social ascendente, o grupo não-branco, experimenta uma dupla desvantagem. A primeira deve-se à sua baixa origem social $\mathrm{e}$ a segunda advém da desvantagem competitiva, sofrida do nascimento até a morte, que resulta da adscrição racial. Em suma, quando as diferenças inter-raciais de mobilidade social são analisadas, controlando-se a origem social, as diferenças observadas podem ser atribuídas seja aos efeitos mais simbólicos e indiretos do racismo - i.e., estereótipos culturais que se autoconfirmam, limitando as aspirações e motivações das pessoas de cor - seja aos efeitos diretos da discriminação racial. (HASENBALG, 1979 , p. 208-209).

Após a fala de Odara, Dudu prossegue com suas observações acerca do tratamento dado à pessoa negra, em virtude de suas características raciais, particularmente a cor de pele.

Dudu: Uma vez eu estava assistindo um.... Eu até comentei contigo Odara. Era tipo um fato da vida real, passou alguém contando um caso assim... na Band, tem muito tempo atrás... o filho de uma mulher nos EUA viajou, veio para a América Latina, e ele era médico.... Acho que era Médico Sem Fronteiras e ele conheceu uma mulher aqui, uma mulher negra, e ele falou: "Mãe eu conheci uma mulher" e tal. Só que ele não falou, não descreveu a mulher. A mãe falou: "Traga aí para eu conhecer". E ele falou que ela ainda ia morar com ele. Então, ele falou: "Ela vai na frente porque eu tenho trabalhos ainda a serem cumpridos, depois eu vou". E ela foi. E isso coincidiu no mesmo dia em que a mãe contratou a empregada. A mãe ligou para a empresa, contratou a empregada e tal, terceirizada, e quando a mulher do filho dela chegou, bateu na porta ela era negra, negra do cabelo armado assim black. Quando bateu ela nem perguntou quem era, já puxou para dentro assim: "Para que tantas malas?" Perguntou para a empregada, né? ..."Para que tantas malas?" Puxou para a cozinha e deu logo um avental para ela. Aí, a mulher ficou quieta. A mulher falava três línguas era muito culta, sabe?...muito erudita assim. Ela decidiu fazer um teste com a mulher e ficou quieta. Aí, poucas horas depois a empregada chegou. E a empregada era branca. Quando ela viu: "Oh meu bem, estava te esperando, te esperei tanto tempo. O meu filho falou muito de você". E a empregada tirou proveito da situação, ficou quieta. Depois lá na frente quando o filho chegou que isso foi desfeito, aí a mãe mostrou o preconceito dela. Disse: "Ah você está namorando com uma negra? Eu pensei que ela era empregada". Então, isso de fato acontece nos dias de hoje. Não sempre nesse contexto, sabe? Mas acontece assim... É... Eu sou preto, Odara é branca. Aí, eu dou um discurso com a dicção boa e as pessoas não esperavam isso, esperavam mais dela. Porque realmente não se espera isso de um negro. Já internalizou isso: "Negro?" "Negro é uma pessoa que não se importa com a vida", "Negro é uma pessoa que tem que trabalhar e não tem tempo para estudar”. Já internalizou isso. Então, se dá mais valor à pessoa pela cor do que pelo que de fato ela é. Isso acontece muito ainda.

Segundo Guimarães (2008, p. 55), “[...] marcadores físicos podem estar ausentes e ainda assim raças serem constituídas, como o foi a 'raça judia'. Do mesmo modo, diferenças físicas

\footnotetext{
${ }^{84}$ A pessoa branca pode sofrer discriminação por ser pobre, mas ainda assim usufrui do privilégio da brancura. Segundo SCHUCMAN (2012, p. 109), "[...] quando comparamos negros pobres com brancos pobres percebemos que os significados construídos em torno da pertença racial branca asseguram a eles privilégios e vantagens em diversos setores sociais". Ou seja, a hierarquização social que divide brancos e negros permanece, mesmo no interior dos bolsões da pobreza (CARRIL, 2006b).
} 
ou culturais não são marcadores por si mesmos. Apenas diferenças erigidas em marcadores e fronteiras se tornam importantes". No caso do racismo brasileiro, o principal marcador visível erigido para construir fronteiras raciais entre grupos sociais é a cor, seguida de outras características fenotípicas.

\begin{abstract}
Logicamente os traços negros e brancos só têm significado dentro de uma ideologia preexistente, de uma ideologia que cria os fatos e marcas classificatórias. Isso significa que alguém só pode ter cor e ser classificado num grupo de cor, se existir uma ideologia na qual a cor tenha significado. As pessoas têm cores apenas no interior de ideologias raciais. Isto implica necessariamente uma visão hierárquica estereotipada, pela qual as pessoas são pré-definidas, entre negros e brancos, como mestiços, mulatos, pardos (BRITO, 2003, p. 188).
\end{abstract}

Munanga (2004b, p. 52) explica que "[...] os conceitos de negro e de branco têm fundamentos etno semântico, político e ideológico, mas não um conteúdo biológico". Tais conceitos são criados pelo racismo, que se fundamenta na ideia de "raça" para racializar os sujeitos sociais. Segundo Munanga (2015, p. 48), ainda que se tenha provado que a raça não existe do ponto de vista biológico, ela existe enquanto construção social, ou seja, permanece no imaginário social, a velha hierarquização, forjada pelo racismo, que divide os grupos humanos em inferiores e superiores, afirmando haver uma "[...] relação intrínseca entre as diferenças biológicas, as aptidões intelectuais, morais, psicológicas e estéticas".

Portanto, no imaginário, "raça" simboliza status e poder (CASHMORE, 2000). Sendo assim, como bem exemplificado na fala de Dudu, as características físicas são utilizadas como símbolos de diferenciação social. Segundo Munanga (2015), "raça” é uma construção social e política que persiste no imaginário coletivo e continua vitimando pessoas e grupos humanos.

\footnotetext{
Ao decretar, no início da segunda metade do século XX, que cientificamente a raça não existe, o racismo científico deixou de existir, mas o racismo de fato já incorporado nas culturas de diversas sociedades continua a persistir, e é contra ele que se luta hoje. As raças como construção sociológica ou política continuam a existir no imaginário coletivo de todos os racistas, e a raça como noção e ferramenta de análise sociológica e histórica se mantém no vocabulário das ciências sociais. Não se trata mais de raças biológicas, mas sim de raças sociais. Em outros termos, depois da morte científica da raça, seu filhote "racismo" continua solto no mundo e faz vítimas independentemente da mãe já morta. ${ }^{85}$
}

Muitos cientistas sociais fazem uso do conceito de raça como ferramenta de análise, tal como Guimarães; outros preferem evitar seu uso, buscando não cair nas artimanhas ideológicas, como Munanga, que utiliza em seus escritos o conceito de população ou de sociedades humanas; outros, como Cunha Junior (2007, p. 71), abominam o seu uso, justificando que “[...] racismos são produtos do uso do conceito de raça". O autor utiliza o termo afrodescendência,

${ }^{85}$ Ibid, p. 48 
enfatizando a importância de se compreender a história sociológica e os processos de construção de identidade dos afrodescendentes em suas dimensões política e cultural. Segundo Sansone (2004, p. 16), de uma forma ou de outra, até mesmo aqueles que negam o seu uso, têm de se haver com sua popularidade:

Talvez a melhor maneira de responder ao emprego popular do termo "raça", para os antropólogos como eu, não consiste apenas em evitar o seu uso. Ao contrário desconstruir o significado da negritude e da branquidade no contexto de nossos locais de pesquisa, e devemos insistir em falar em (processos) de racialização, em vez de entrarmos em sintonia com o clima popular e começarmos a usar "raça" sem nenhum questionamento de sua naturalidade intrínseca, como parece disposto a fazer um número crescente de cientistas sociais.

Assim como raça não precisa de um marcador físico para existir,

[...] o racismo no século XXI não precisa mais da base pseudocientífica ou do conceito de raça. Ele se formula com base em outras essencializações como etnia, cultura, identidade, história. É um racismo diferencialista e não mais cientifico. [...] o racismo como ideologia pode parasitar por todos os conceitos, mesmo por aqueles considerados neutros (MUNANGA, 2015, p. 50).

Portanto, "raça" enquanto construção social se constitui em racismo, em violências concreta e simbólica, que afetam sua identidade, abalam sua autoestima. A não cientificidade da "raça" não impede que ela seja operante nas relações sociais e, por conseguinte, se mantenha atuante na hierarquização social. Simbolicamente, "raça" permanece alimentando discriminações e preconceitos, perfaz caminhos antigos e cria novos caminhos de atuação, sejam explícitos ou implícitos, tendo no silêncio, um forte aliado.

Os depoimentos dos participantes nos dão exemplos da operatividade da ideia de "raça" no imaginário coletivo. Ela se fundamenta através da racialização dos corpos de sujeitos sociais, que fundamenta hierarquização social entre grupos e incide na formação de identidades raciais rotuladas a partir de estereótipos. Para Glass (2012, p. 887), "Isso sustenta que a raça diz tudo o que é mais importante sobre uma pessoa e define suas capacidades intelectuais e morais, indicando até suas inclinações de trabalho, atléticas ou sexuais". Como o depoimento de Dudu revela, a ação dos estereótipos impede que a pessoa negra seja compreendida em sua individualidade, o corpo diz tudo o que é preciso saber, vincula-se a ele uma identidade préconcebida.

Os estereótipos com relação à pessoa negra lhe impingem “[...] 'irracionalidade' e 'primitivismo', em oposição à 'racionalidade' e 'refinamento' do branco" (SOUZA, 1983, p. 30). Dudu menciona alguns significados do "ser negro" internalizados pelos sujeitos sociais: "Negro é uma pessoa que não se importa com a vida", "Negro é uma pessoa que tem que trabalhar e não tem tempo para estudar". Até mesmo os estereótipos que aparentam certa 
valorização, por exemplo, aqueles relativos à longevidade, à potência sexual, à destreza física, não passam de falso reconhecimento (SOUZA, 1983). Assim, os famigerados discursos relacionados à resistência física, à capacidade do negro para o trabalho pesado, têm como intuito dissociar a pessoa negra da atividade mental, intelectual (GILROY, 2007) e, dessa maneira, naturalizá-la como inferior. As representações sociais e estereótipos associam a pessoa negra a padrões de comportamento, identificações culturais, até mesmo a expectativas.

Como bem revelado por Dudu, espera-se que o negro esteja sempre em situação social subalterna, como empregado do branco, que ele não saiba se expressar como um branco, entre outros. Ser negro é constante estado de falta, sempre tem que provar que pode ser melhor do que já é, vive a sensação de que tem que ser mais e mais. O indivíduo pode ser levado a “"[...] 'compensar' suas marcas pela ostentação de aptidões e características que impliquem aprovação social tanto pelos de sua própria condição racial (cor) como pelos componentes do grupo dominante e por indivíduos de marcas mais 'leves' que as suas [...]”' (NOGUEIRA, 1954/2006, p. 301).

A "raça" não tem efeito negativo na vida do branco, seu corpo não é racializado negativamente, ao contrário, ele se encaixa com neutralidade no universo racializado, onde não tem um "lugar" determinado para ele:

[...] Ser branco significa uma condição genérica: ser branco constitui em elemento não marcado, o neutro da humanidade. [...] Ser negro não é uma condição genérica; é uma condição especifica, é um elemento marcado, não neutro (NOGUEIRA, 1998, p. 91)

Dessa forma, o branco vive em situação de conforto, vivencia a sensação de não representar nada além de sua própria individualidade, tem o direito de se autodeterminar (PIZA, 2007). Não é constantemente perturbado pela "raça", porque é privilegiado por sua existência e seus efeitos, logo, ela não é um problema para ele. Em contrapartida, a pessoa negra tem que se haver cotidianamente com a "raça" e o racismo.

Munanga (2015) alerta que na sociedade brasileira a não cientificidade da "raça" é utilizada para dizer que não existe racismo. Hasenbalg (1979, p. 210-211) assinala. "Para os brasileiros brancos, o endosso público da ideologia da democracia racial e da harmonia racial funciona - como na confissão católica - como forma de expiar a culpa despertada por sentimentos racistas interiores e disfarça suas práticas discriminatórias privadas." O mito da democracia racial funciona em razão da "cegueira racial” (GLASS, 2012) cínica, em que "não perceber a raça" ou, em outras palavras, fingir-se de cego, é estratégia utilizada pelo grupo dominante para manter seus privilégios. Para o autor, enquanto indivíduos sociais, estamos 
inexoravelmente inseridos em uma ordem racial e internalizamos ideologias que moldam nossas práticas atitudes e sentimentos.

Portanto, nenhuma pessoa “[...] é atualmente capaz de 'não ver' as características fenotípicas e morfológicas de pessoas que são os símbolos culturalmente definidos de raça mesmo se sua visão de cor for fisiologicamente prejudicada devido a estrutura de sua retina" (GLASS, 2012, p. 891). Hasenbalg (1979, p. 83) assinala que "[...] independentemente do conteúdo irracional das crenças e ideologias raciais, as práticas racistas podem ser racionais em termos da preservação da estrutura de privilégio e dominação dos brancos". Para o autor, muitos brancos se aproveitam da opressão racial, visto que ela lhes proporciona vantagens na competição com os negros garantindo-lhes, portanto, ganhos materiais e simbólicos. Silenciar sobre os efeitos do racismo, assim como sobre o papel que desempenham na manutenção das desigualdades sociais é, para eles, condição si ne qua non para manter seu privilégio racial (BENTO, 2007). Daí decorre o interesse do branco na dissimulada "cegueira racial":

[...] nega as realidades da raça e do racismo, não reconhece a situação racial da própria branquidade e não compreende que as pessoas de cor (como os deficientes) não apreendem seu mundo como necessariamente deficiente, carente ou vergonhoso. A cegueira racial espera escapar da dor e da ansiedade de lidar com a raça, não tanto pelo benefício das pessoas de cor, mas pelo benefício dos próprios brancos (GLASS, 2012, p. 894).

Muitos autores utilizam o conceito de branquitude (BENTO, 2007; PIZA, 2007; OLIVEIRA, 2007; SCHUCMAN, 2012) para denominar o lugar de privilégio racial, de ser branco, em outras palavras, um lugar de poder. Essa branquitude constitui os sujeitos brancos, conferindo-lhe: "[...] um lugar estrutural de onde o sujeito branco vê aos outros e a si mesmo; uma posição de poder não nomeada [...]" (PIZA, 2007, p. 71). O fato do privilégio se manter por meio da opressão racial, sugere que “[...] além da exploração econômica, o grupo dominante branco extrai uma certa 'mais valia' psicológica, cultural e ideológica” (HASENBALG, 1979, p. 118). O acordo tácito que permanece entre os brancos é dizer "não percebo a raça", negar a existência do racismo, eximindo-se da culpa, que é atribuída ao negro.

São comuns argumentos que procuram disseminar a ideia de que racista é quem tem problema com o racismo, ou seja, o negro, justificando que é ele quem fala ou acusa outras pessoas de racismo. Embora a experiência de pessoas negras e brancas sejam atravessadas pela "raça", o fato de não haver, no meio social, estereótipos em relação à branquitude, faz com que o branco seja concebido no imaginário social como destituído de raça, por isso a branquitude nunca é questionada e o branco é poupado. Conforme salienta Hirano (2013, p. 85).

Ou seja, a "estrutura de sentimentos" da branquitude faz com que o racismo, ou os estudos de relações raciais, sejam algo percebido como restrito ao universo negro, se 
assentando na pretensa concepção desse imaginário de que o branco se constrói destituído de uma ideia de raça. Como demonstra Dyer, o imaginário da branquitude (ou, nos termos de Stam e Shohat, o eurocêntrico), é fruto de séculos de uma dominação que produziu uma infinita visibilidade do branco nas formas expressivas canônicas do ocidente, como a literatura, as letras de música, o cinema e o teatro. Paradoxalmente, isto o tornou um ente invisível, como se fosse destituído de raça. Em contraposição, a invisibilidade generalizada do negro e de outros grupos estigmatizados na economia das representações resulta numa visibilidade exagerada, pois suas aparições pontuais são decodificadas como imagens equivalentes a toda a população negra, ignorando-se o fato de que esta é tão complexa e diversa como qualquer grupo humano.

Nessa mesma perspectiva, Gonçalves Filho (2017, p. 146, acréscimo nosso) alerta que “[...] os brancos não são percebidos por um só traço e um traço rebaixado", ao contrário do negro, para o qual a "invisibilidade e a superexposição por um só traço identitário são como duas faces de um só golpe [o racismo]". Ao procurar fugir da discussão, dizendo ser o racismo um problema relativo aos negros, o branco reitera sua posição de privilégio. Enquanto o racismo não for compreendido como um problema que envolve a todos, independentemente de sua pertença racial, pouco avançaremos em seu combate.

Se os impactos do racismo não são pensados de modo mais amplo, argumentos irracionais, que o tomam como algo de ordem individual, acabam se mantendo operantes, enquanto produtores de alienação da identidade e de desigualdades. Cabe ao negro, no sentido político, tornar-se negro, afirmar sua identidade negra, e atuar no combate ao racismo; e cabe ao branco deflagrar sua atitude política de combate ao racismo, começando pelo reconhecimento de sua condição de privilégio.

Considerando que a identidade é construída em relação à representação do nosso grupo social, o branco constrói uma autoimagem que fortalece sua autoestima, enquanto o negro, uma autoimagem depreciativa. Construir identidade negra positiva equivale a desconstruir a imagem negativa formulada socialmente a respeito da população negra, ressignificar toda carga pejorativa que a sociedade insiste em lhe atribuir. Retomamos, aqui, uma fala de Dudu, anteriormente citada - que ilustra bem essa questão.

Dudu: Então, nisso [de verificar o tratamento desumano com que a população negra foi historicamente tratada] eu ficava pensando assim: "Eu tenho que parar com isso, tenho que parar com esse pensamento preconceituoso". Foi então quando eu comecei a me encontrar e hoje quando eu falo assim: "Eu sou negro". Sinceramente, de todo coração, de lá do fundo, quando eu falo assim: "Eu sou negro e ninguém está aí para me oprimir". Eu faço um respiro de alívio, enfim... enfim eu não me preocupo mais com meus lábios, com meu nariz, com a cor da minha pele. Enfim, eu não me preocupo mais com certas coisas, sabe? ...que eu trago da minha cultura. Eu faço assim: [respira com alívio] "Aí, enfim eu estou livre, ninguém mais, mesmo que queira, vai me oprimir. Eu não vou me deixar ser oprimido como eu deixei”. Então, isso foi um... [gesto de respiro e alívio] ...sabe? Quebrou, rompeu com os grilhões, e eu me aliviei. Então, antigamente, quando alguém olhava para mim: "Tu é preto". Era a briga: "Não sou não". Hoje em dia fala: "Menino tu é preto". Eu falo: "Ainda bem". 
Hoje a minha irmã fala para mim: “Tu é preto". E às vezes eu até brinco... brinco assim, eu brinco, mas é uma brincadeira que é uma crítica. Quem me conhece sabe que eu sou muito crítico, que às vezes eu só estou alfinetando ali... Então, a pessoa vem de lá: "Ah não sei o que e tal". Eu falo: “Tu é preto". Para a pessoa parar e pensar. Não no sentido pejorativo. Mas a pessoa vem: "Eu fiz isso não deu certo". Eu falo: "Sabe por que? ...o preto só anda sendo marginalizado". Aí, a pessoa para e pensa...

O depoimento de Dudu nos mostra o quanto é longo esse processo de construção positiva de identidade, que acaba por envolver uma descoberta de si e do outro. Ao adquirir consciência da marginalização histórica sofrida pela população negra, ele pôde reconhecer que as atitudes e sentimentos negativos internalizados com relação ao seu grupo étnico-racial foram decorrentes do racismo. Inicia a desconstrução do "ser negro", construído e pensado pelo racismo, a partir de um diálogo interno, na busca de enunciados da "verdade" sobre sua identidade. A ressignificação do "ser negro" envolveu uma reconstrução de si e a reconciliação com seu próprio corpo, na medida em que a relação com ele pode ser percebida como resultado de construções sociais.

Aliás, é somente nesse momento que Dudu consegue "estancar" a "ferida" que sangra. A narrativa de Dudu, sobre o processo de construção de uma identidade em que ele deixa de ser "marrom" para tornar-se negro, nos faz recordar o poema "Gritaram-me negra", de Victoria Santa $\mathrm{Cruz}^{86}$, assim como de uma das passagens do livro de Tulio Henrique Pereira, Pele e sensibilidades. Trata-se de narrativas pessoais belíssimas vão da descoberta do "ser negro" em uma sociedade racista até a reivindicação da identidade negra. As três narrativas demostram os grilhões a que a pessoa negra se vê tão precocemente acorrentada, “[...] diga-se a humilhação das correntes que o identificam como o escravo e o generalizam como tal, do cabelo considerado "ruim", por ser crespo [...]" (PEREIRA, 2011, p. 15), da pele por ser preta, do nariz por ser largo, da boca, por ter lábios grossos. Logo na infância, requisitada por sua estética, a primeira coisa que lhe é tirada é o seu próprio nome

A ressignificação da identidade negra passa pela valorização do corpo, quando o sujeito adquire consciência da história que o corpo negro carrega, do lugar histórico que ele ocupa, o que pressupõe reconhecimento de que os significados sobre seu corpo são representações sociais atribuídas pelo opressor. Quando localiza o opressor dentro de si, pode combatê-lo e se libertar do peso dos grilhões, como ocorre com Dudu, que se apodera do corpo, deixa de habitar um corpo que aprisiona, passa a senti-lo como um corpo que liberta, passa a coincidir eu-corpo, passa a "ser" seu corpo e, assim, se empodera, troca os discursos ofensivos por discursos por ele próprio produzidos. A culpa de situações de preconceito não mais será atribuída ao corpo

${ }^{86}$ Disponível em: https://youtu.be/lN5M0jehU7s. Acesso em: 20 nov. 2017. 
que carrega e, por conseguinte, a si mesmo, mas a circunstâncias exteriores. Sabe que ainda será alvo de atitudes racistas, mas, empoderado de si, desenvolve meios de autodefesa.

A partir de então, ninguém mais o oprime, sabe agora dizer quem é e, então, se alivia. A afirmação da identidade negra passa pela afirmação do corpo, pela superação do estigma que, muitas vezes, impede o sujeito de desenvolver sentimento de pertencimento racial e, paralelamente, de construir a autoestima e identidade racial positiva. Agora, Dudu assume uma atitude política de levar o outro a se questionar, a dialogar sobre o porquê das condições subalternas da população negra e a vê-las como materialidade do racismo, implícito em situações cotidianas. Ele espera incentivar o outro a descobrir que, muitas vezes, não consegue atingir seus objetivos não por incapacidade pessoal, mas devido a condições ocasionadas pelo racismo e ao duplo limite que impõe às aspirações da população negra: para que as tenha ou para que as possa realizar.

Segundo Baraúna (2007, p. 144), “[...] é provável que, em muitos casos, o que move a busca de uma identidade negra é um mal-estar frente à própria autoimagem, causado pelas condições dadas socialmente [...]". Consideramos que a pessoa negra, sobretudo, é movida pela mesma necessidade que o levou à autonegação identitária: o reconhecimento social, que compreende consideração de sua dignidade e direito à autodeterminação.

A construção da identidade negra é específica para cada pessoa. Embora as práticas racistas agressivas que vivenciam cotidianamente sejam semelhantes, cada um tem sua forma de tornar-se negro. Essa construção da negritude passa pelo corpo, abrangendo também a consciência de que faz parte de um coletivo "[...] marcado por uma história comum que o olhar do mundo ocidental 'branco' reuniu sob o nome de negros” (MUNANGA, 2012, p. 12). História essa, como diz o autor, caracterizada por um intenso processo de desumanização, destruição e negação sistemática de culturas. Nesse sentido, ser negro é:

\footnotetext{
[...] tomar posse desta consciência e criar uma nova consciência que reassegure o respeito às diferenças e que reafirme uma dignidade alheia a qualquer nível de exploração. Assim, ser negro não é uma condição dada, a priori. É um vir a ser. Ser negro é tornar-se negro (SOUZA, 1983, p. 77).
}

Souza (1983) argumenta que compartilhar uma história de opressão não organiza por si só uma identidade negra, é preciso reivindicá-la política e coletivamente. Segundo Hall (2006, p. 21). "[...] uma vez que a identidade muda de acordo como o sujeito é interpelado ou representado, a identificação não é automática, mas pode ser ganhada ou perdida. Ela tornouse politizada". Por conseguinte, a identidade negra, seja do ponto de vista individual, seja coletivo, é uma escolha, um posicionamento, como nos diz Odara, é um ato político: 
Pesquisadora: Vocês se auto definem como...?

Dudu: Negro com certeza.

Oré: Negro.

Muraguili: Negra.

Pesquisadora: E você Odara?

Odara: Não sei.

Makbo: Eu sou negro.

Pesquisadora: Eu também.

Todos: Risos.

Dudu: É tão bom... É tão bom quando você se reconhece e diz assim: "Eu sou negro".

Dá aquela respirada assim [respira fundo] ... sou livre. É aquela coisa assim "Eu sou negro". "Não você não é negro não" ...Quando eu era criança me falavam: "Você é negro". E eu: "Não, eu não sou negro não, eu sou marrom". E tinha gente que falava assim: "Você é moreno jambo". É. Mas quando você fala assim: "Sou negro e ninguém me oprime mais". Dá aquela, sabe?... Aquela coisa assim... Chego me arrepio. Da aquela coisa assim... [respira fundo de alívio; fica emocionado].

$[\ldots]$

Odara: Eu conheço... A "me gritaram me negra"?

Pesquisadora: E o que vocês entendem por identidade negra?

Odara: É um ato político, né? O movimento negro taí para mostrar isso.

Dudu: Identidade negra eu acho que é aquilo que vai ser construído a partir da cultura negra. É aquilo que você vai agregar aos seus valores. Porque eu vou não só... porque hoje é assim...Você vai mesclar... Mas a identidade negra vai ser a cultura do negro, vai ser o modo de ver o mundo do negro, vai ser a vivência do negro em si, vai se concentrar tudo aí. Eu vejo dessa forma. Então, identidade negra vai ser eu aceitar a cultura negra, eu respeitar a cultura negra, sabe?... Eu viver naquele contexto da cultura negra. Embora eu tenha religião de matriz europeia, mas eu respeito muito a cultura africana. Eu vejo de certa forma assim... É como se fosse assim... Se eu tentasse repor aquele tempo todinho que eu perdi em relação àquela visão. Então, hoje eu tenho mais cuidado...Quando alguém fala assim: "Ah fulano é isso". [...]

O silêncio de Odara sinaliza, mais uma vez, o corpo como elemento marcador de identidade negra, uma vez que ela não se identifica como negra, embora essa seja a sua vontade, por reconhecer que, por ter a pele mais clara, não sofre discriminações ou preconceito como Dudu. Neste caso, o fato de não se identificar como negra pode ser compreendido como um ato político, não no sentido de afirmação de identidade, mas um ato político de reconhecimento de posição de privilégio com relação a pessoas negras.

Munanga (2015, p. 50) ressalta que as construções política e coletiva da identidade resulta de organização e mobilização dos grupos, sendo possível mediante a consciência identitária dos indivíduos que, por sua vez, só pode ser construída através do entendimento de quem somos na formação histórica do nosso país. Dessa forma, tornam-se fundamentais nesse processo, os seguintes questionamentos: “Quem somos, de onde viemos e por onde vamos?" A identidade individual ou coletiva é sempre processo em construção e só pode ser compreendida se considerarmos os contextos históricos e políticos em que foram forjadas.

[...] não é possível dissociar o estudo da identidade do indivíduo do da sociedade. As possibilidades de diferentes configurações de identidade estão relacionadas com as diferentes configurações de ordem social. [...] é do contexto histórico e social em que o homem vive que decorrem suas determinações e, consequentemente, emergem as 
possibilidades ou impossibilidades, os modos e as alternativas de identidade (CIAMPA, 2001, p. 72).

Os indivíduos são ativos nesse processo de construção de identidade, os contextos e situações sociais interferem nessa construção, por isso não podemos dizer que ela seja fixa e imutável. Para Hall (2000), a identidade é constituída a partir de pontos de identificação e suturas, encontro entre as práticas e discursos que interpelam e convocam o sujeito a assumir determinada posição, e, por outro lado, a partir das subjetividades relativas aos próprios sujeitos. No entanto, “[...] uma suturação eficaz do sujeito a uma posição de sujeito exige não apenas que o sujeito seja 'convocado', mas que o sujeito invista naquela posição, então suturação tem que ser pensada como uma articulação e não como um processo unilateral" (HALL, 2000, p. 112). Torna-se central a questão da identificação.

A concepção de identidade do autor auxilia na compreensão da identidade negra e quilombola como ato político, um posicionamento, uma vez que o investimento do sujeito em determinada posição é fundamental para que a suturação (ou identificação) ocorra. Por isso, são tão necessárias desconstruções de estereótipos e, ao mesmo tempo, visibilidade de práticas e discursos de referenciais positivos de identificação com a cultura, história, entre outros elementos da cultura africana e afro-brasileira.

$\mathrm{O}$ racismo desconsidera as diferenças individuais, cria identidades fixas e fragmentadas, transforma a identidade em algo dado, desconsiderando seu caráter processual, marcado por identificações contínuas. Ele funciona como mecanismo fixador de identidades, atua no sentido de essencializar os sujeitos e grupos sociais, na medida em que essencializa as posições identitárias a partir do binarismo negro/branco. Segundo Hall (1996, p. 68), identidades coletivas são “[...] quadros de referências e sentidos de referência e sentidos estáveis, contínuos e imutáveis por sob as divisões cambiantes e as vicissitudes de nossa história real". Nota-se que identidade coletiva compreende uma certa essencialização, necessária para agregar indivíduos, formando uma coletividade. No entanto, o racismo cria identidades coletivas estereotipadas.

Ao falarmos sobre identidade coletiva, é preciso diferenciar duas dimensões pelas quais ela pode ser concebida, conforme discutimos anteriormente: identidade coletiva atribuída, formada a partir da seleção de sinais diacríticos (atributos selecionados a partir do seu complexo cultural - religião, política, economia, artes, visão de mundo) pelo grupo opositor; e identidade coletiva autoatribuída ou de autodefinição, que se forma quando o próprio grupo seleciona sinais diacríticos para se autodefinir (MUNANGA, 2012b). Ambas as dimensões da identidade 
são coletivamente construídas e se transfiguram conforme os contextos social, cultural e político.

No entanto, a identidade atribuída à população negra é dotada exclusivamente de um caráter essencializador, na medida em que relações de poder estão envolvidas na essencialização do que é ser negro. Entendendo que a construção da identidade é algo específico para cada pessoa, essa essencialização desconsidera o próprio sentido de identidade. Cada pessoa negra constrói sua identidade e negritude de maneira distinta, assim existem infinitas formas de "ser negro". Sendo assim, "ser negro" não pode ser apreendido através de um consenso. Essencializar o "ser negro" é o mesmo que essencializar as subjetividades. Como alerta Hall (2003), "negro" não é uma categoria de essência, existe uma diversidade de experiências históricas, culturais que localizam, situam e posicionam a população negra.

Hall (1996) relata que, ainda que pareça ambivalente, a condição essencialista constituise em instrumento importante na formação e organização de movimentos sociais, uma vez que, a construção da identidade coletiva é construída através da constituição de referências fixas que possam unificar os sujeitos pertencentes a determinados grupos sociais.

\footnotetext{
Mas é justamente por resultar de formações históricas especificas, de histórias e repertórios culturais de enunciação muito específicos, que ela [a identidade] pode se constituir em 'posicionamento', ao qual nós podemos chamar provisoriamente de identidade. Isto não é qualquer coisa. Portanto, cada uma dessas histórias de identidade está inscrita nas posições que assumimos e com as quais nos identificamos. Temos que viver esse conjunto de posições de identidade com todas as suas especificidades (HALL, 1996, p. 443, acréscimo nosso)
}

Para o autor, as diferenças são centrais na constituição das identidades dos sujeitos sociais, e não devem ser entendidas como simples oposição binária, mas como algo mais complexo e aberto.

[...] nossas diferenças raciais não nos constituem inteiramente, somos sempre diferentes e estamos sempre negociando diversos tipos de diferenças -de gênero, sexualidade, classe. [...]. Estamos constantemente em negociação, não com um único conjunto de oposições que nos situe sempre na mesma relação com os outros, mas com uma série de posições diferentes. Cada uma delas tem para nós o seu ponto de profunda identificação subjetiva ${ }^{87}$

Nessa perspectiva, Hall (2003) alerta para o fato de que, no interior da própria identidade coletiva, seus significantes sejam compreendidos como agregadores de sujeitos com suas diferenças. A reflexão do autor gira em torno da nova dinâmica dada ao sentido de identidade pelos movimentos sociais (feminista) na sociedade moderna, em que há a substituição de uma política de identidade pela política da diferença. Ao colocar as diferenças em foco, esses

${ }^{87}$ Ibid., p. 346. 
movimentos introduzem "[...] dúvidas e rupturas na própria ideia de identidade" (SOUZA, 1994, p. 39). Pautado em uma política da diferença, o movimento negro trabalha historicamente pela constituição de uma identidade negra coletiva e política que possa reunir “[...] negros e negras de todas as classes sociais, de todas as religiões, de todos os sexos, porque juntos todos são vítimas da discriminação e exclusão raciais” (MUNANGA, 2012b, p. 13).

A identidade negra coletiva autoatribuída pelo movimento negro não se configura em "uma essência, mas um posicionamento" (HALL, 1996). Porém, não se pode negar que em seu percurso histórico de construção e reconstrução recorre a um certo "essencialismo estratégico". Afinal, "[...] temos o direito de sermos iguais quando a diferença nos inferioriza e a ser diferentes quando a igualdade nos descaracteriza" (SANTOS, 2002, p. 75).

Segundo Munanga (2012b, p. 13), é recorrente a crítica feita por representantes da elite, intelectuais e políticos, às entidades e ao movimento negro quando estes reivindicam uma identidade negra de cunho político. Tais críticos, argumentando que a nossa identidade é mestiça, frequentemente acusam esses movimentos de "racismo às avessas" ou da tentativa de dividir o país em "raças". "Essa crítica tem a ver com o fato de não existir um discurso político sobre a identidade branca, apesar de esta existir tacitamente, pois todos têm consciência das vantagens que a branquitude lhe oferece nesta sociedade".

Não é necessária a mobilização política em torno de uma identidade branca, heterossexual, ou masculina, visto que são identidades hegemônicas, consolidadas socialmente (MUNANGA, 2012b). Quem necessita mobilizar-se em torno de uma identidade são aqueles cujas diferenças são classificadas como inferiores, aqueles que não têm poder de representação. A questão da identidade apresenta-se, para aqueles que precisam constituí-la, como um contrapoder, sua formulação, portanto, é, como diz Boaventura de Sousa Santos (1999, p. 121), uma ficção necessária: "Quem pergunta pela sua identidade questiona as referências hegemônicas [...] A questão da identidade é assim semifictícia e seminecessária". O título da obra de Hall, "Quem precisa de identidade?" é bem propício para refletirmos sobre a necessidade de grupos sociais se organizarem em instituições e promoverem discursos em torno de uma identidade a fim de reivindicar equidade social.

É precisamente porque as identidades são construídas dentro e não fora do discurso que nós precisamos compreendê-las como produzidas em locais históricos e institucionais específicos, no interior de formações e práticas discursivas específicas, por estratégias e iniciativas específicas. (HALL, 2000, p. 109).

O depoimento de Dudu revela a cultura como um elemento importante na constituição da identidade negra. Ele inicia um novo processo de identificação referenciada em valores 
africanos e afro-brasileiros, reconhecendo a importância das matrizes africanas na construção de sua identidade. Mas é como se ainda estivesse procurando por uma identidade negra exterior, como se ainda lhe faltassem elementos para se sentir completamente pertencente a um coletivo. Sente que deve recuperar o tempo perdido, fica implícito um sentimento de culpa por ter se mantido alienado e desperdiçado tempo com a internalização de coisas negativas com relação ao "mundo negro".

Segundo Munanga (2012b), além da cultura (religiões, artes, medicinas, tecnologias, ciências, educação, visões do mundo, etc.,) o movimento e as entidades negras pontuam outros três fatores importantes na concepção da identidade negra: história, as línguas e o fator psicológico. No entanto, esses fatores não são objetos históricos fixos a serem apreendidos pelos sujeitos. Há sim, como alerta Hall (2003), uma importância sobre o estudo do passado para reconstruir as genealogias do povo negro na diáspora, para trazer à tona histórias reais, "rotas" culturais que foram invisibilizadas e fragmentadas pela escravidão e colonização.

Trazê-las ao presente possibilita a construção de um "terreno histórico", parafraseando o autor acima citado, que possibilita conferir sentido às nossas matrizes culturais, redescobrir "rotas" africanas no interior da cultura brasileira, a fim de construir nossas africanidades. Entretanto, no processo de construção da identidade, esses recursos são transformados, reelaborados pelo sujeito. As identidades têm a ver "[...] com a utilização de recursos da história, da linguagem e da cultura para a produção não daquilo que nós somos, mas daquilo no qual nos tornamos" (HALL, 2000, p. 109).

Hall (2003) enfatiza a relação dialética e recíproca entre a cultura e o indivíduo, e o caráter dinâmico da cultura e da tradição. Na perspectiva por ele apresentada, o "resgate" da tradição nunca é um "retorno às raízes", mas uma "invenção da tradição". A tradição consiste em um mesmo que se transforma no processo dialógico entre o sujeito e a cultura, em que esse exerce papel ativo, como negociante de suas próprias "rotas" e posições identitárias. Por meio da cultura costuramos, suturamos aquilo que chamamos de nós mesmos, por meio dela caminhamos para nos tornarmos algo além do que somos, ela nos possibilita o vir a ser e nos precede naquilo que ainda não somos.

[...] a cultura não é apenas uma viagem de redescoberta, uma viagem de retorno. Não é uma "arqueologia". A cultura é uma produção. Tem sua matéria-prima, seus recursos, seu "trabalho produtivo". Depende de um conhecimento da tradição enquanto "o um mesmo em mutação" e de um conjunto efetivo de genealogias. Mas o que esse "desvio através de seus passados" faz é nos capacitar, através da cultura, a nos produzir a nós mesmos de novo, como novos tipos de sujeitos. Portanto não é uma questão do que as tradições fazem de nós, mas daquilo que nós fazemos das nossas tradições. Paradoxalmente nossas identidades culturais, em qualquer forma acabada, estão a nossa frente. Estamos sempre em processo de formação cultural. A cultura não é uma questão de ontologia, de ser, mas de se tornar. (HALL, 2003, p. 44). 
A cultura não é algo que possa ser possuído, mas algo a ser construído, vivido. Dessa forma, não há uma cultura negra ou uma negritude pronta para ser absorvida por osmose assim que o indivíduo toma consciência das ideologias e das implicações que essas causam a sua identidade. A negritude é algo construído, não é algo material que se possa pegar, não faz parte de um passado ancestral do qual os indivíduos possam tomar posse. Temos que tomar cuidado para não essencializar essas categorias (cultura e negritude) através de discursos que possam naturalizá-las, retirando-as de seus encaixes histórico, social e político. A negritude remete ao “corpo negro”, mas o ultrapassa, é consciência política. Segundo Hall (2003), não é possível apreender do meio popular formas puras que possam significar a cultura negra, através das quais podemos nos orientar.

Seria mais apropriado descrevê-las como formas impuras e hibridizadas ${ }^{88}$, “[...] adaptações conformadas aos espaços mistos e contraditórios e híbridos da cultura popular" (HALL, 2003, p. 342). São elas, portanto:

[...] produtos de sincronizações parciais de engajamento que atravessam fronteiras culturais, de confluências de mais de uma tradição cultural, de negociações de posições dominantes e subalternas, de estratégias subterrâneas de recodificação e transcodificação, de significação crítica e do ato de significar a partir de materiais preexistentes (HALL, 2003, p. 343).

O autor ressalta que os repertórios da cultura popular negra são espaços sobredeterminados pelas heranças culturais e conexões da diáspora. Nesses espaços, negros e negras puderam tecer suas contranarrativas e expor suas tradições, por meio de um repertório negro, que se caracterizara por seu estilo, sua música, a escrita, e pelo uso do corpo como tela de representação. O encontro entre todo esse patrimônio africano e as ideologias e culturas europeias “[...] conduziram a inovações linguística na estilização retórica do corpo, as formas de ocupar um espaço social alheio, a expressões potencializadas, a estilo de cabelo, a posturas, gingados e maneiras de falar, bem como a meios de constituir e sustentar o companheirismo e a comunidade" (HALL, 2003, p. 343).

A construção da negritude passa pela construção da identidade negra na diáspora, e essa não se resume, segundo Munanga (2012b), à biologia do corpo, mas se caracteriza pelas

\footnotetext{
${ }^{88}$ Segundo Bhabha (1997, apud HALL, 2003, p. 75), hibridismo ocorre quando o grupo se encontra em situação na qual se vê necessário rever seus próprios sistemas de referência (normas valores) devido ao distanciamento de suas regras originais. Esse movimento, segundo o autor, é marcado por ambivalência e ambiguidade na medida em que envolve negociação da diferença com outro. Não se refere simplesmente à apropriação ou adaptação, mas à transição, transformação, relações de poder, reivindicação de posição de poder e tradução de valores éticos e estéticos. Cf: BHABHA, H. The Voice of the Dom. Times Literary Supplement, nº 4923, 1997.
} 
diferenças linguísticas, religiosas, culturais, artísticas, forjadas no contexto da diáspora e sua constante reelaboração, engendramento, recodificações, na medida em que o povo negro buscou recriar-se e movimentar-se na trama do movimento diásporo.

Durante as entrevistas, o tema "apropriação cultural" foi abordado pelos participantes, ao questionarem a transformação de elementos culturais africanos e afro-brasileiros em mercadoria e seu uso por indivíduos pertencentes a outros grupos sociais.

Pesquisadora: O que vocês apontariam como tradicional aqui da comunidade de Barro Preto?

Dudu: A capoeira.

Odara: Em relação à cultura negra?

Pesquisadora: É. Ou pode ser em outros aspectos, o que predomina mais aqui...

Dudu: Alimentação, a dança, até o vocabulário ainda traz certas palavras de origem negra.

Pesquisadora: Aqui na comunidade?

Dudu: Isso. Aqui na comunidade certa vez “Aí, que gíria é essa?”. Aquela gíria com relação ao dialeto.

Pesquisadora: Qual gíria?

Dudu: Tem aquele dialeto assim... Aí, meu Deus ///... fugiu da mente...Para se referir a outra pessoa negra... Então, eu acho que isso ainda está presente sim, isso está na nossa cultura, no nosso linguajar, na nossa alimentação, nas nossas vestes às vezes está presente também. Como é o caso do turbante.

Odara: Eu acho que o turbante está voltando agora, depois que começou a se falar sobre o cabelo crespo, começou a abrir espaço para isso. Aí, agora também tem o lado ruim porque tem gente que vê isso como modismo, sabe? Tipo, "ser negro agora é moda". Aí, vem a apropriação cultural, uma pessoa branca não quer que desconstrua o racismo dela, ela não sabe reconhecer se... tipo... Eu acho que... na minha concepção a pessoa, por ser branca, já traz algo de racista. Os negros reproduzem racismo, imagina os brancos, porque isso já é algo internalizado. É como falar assim: "Ele é um negro bonito". Por que tem que ressaltar que ele é um negro bonito? Por ser negro ele raramente vai ser bonito!? Por que ninguém fala assim? "Ele é um branco bonito". Agora fala: "Ele é um negro até bonito". E tipo, a pessoa branca não quer que a gente aponte: "Não, isso é racismo". "Não, eu não sou racista". Mas quer se apropriar da cultura negra, quer usar trança, quer usar turbante, quer usar as roupas com estampas que lembram a África, mas não quer ser desconstruído.

Dudu: É, isso virou modismo mesmo. Porque, tipo, aqui em Jequié tem a UESB, né? Você já ouviu falar?

Pesquisadora: Sim.

Dudu: Lá na UESB procura abordar muito esta coisa da cultura negra. Não só da cultura negra, mas a homofobia também, e tenta sabe? ...desfazer isso da nossa sociedade. E de certa forma isso que ela colocou: "a cultura negra tem virado modismo". Pelo menos aqui que eu tenho observado, na região, agora é. Tem virado modismo. "Ah agora é massa ter o cabelo cacheado", "Ah agora é massa usar um turbante". "Agora é bom usar uma coisinha que lembra a África". Porque isso de certa forma virou modismo, não virou mais identidade cultural... Para mostrar assim: "Oh! Ela é negra", não só mais pela cor dela, mas pelo que ela usa, pelo linguajar dela. Mas isso virou modismo, virou moda mesmo. Esse é o lado ruim. Cabelo cacheado agora é isso "in natura" a mulher toda natural. Não é aquela coisa assim que vai: "Vou colocar meu cabelo cacheado aqui porque eu reconheci que não preciso ter os padrões europeus, os padrões de branco". Eu tenho que ser negro e reconhecer, e não: "Vou colocar porque atriz tal fez isso, fulana também fez. Ah vou fazer também".

Odara: E você percebe que a coisa está tão crítica quando até a religião de matriz africana se torna modismo. Eu vi uma matéria hoje falando que "pessoas brancas aderiram ao Candomblé e à Umbanda, só que eles fazem o culto da sua forma". Como uma pessoa aderi a uma religião e faz culto da sua forma? Porque até onde eu entendo, apesar de não ser, que eu conheço, tem a mãe e ela que vai falar o que deve fazer. Não 
é aquela coisa: "Eu vou fazer o culto à minha forma". Aquilo não é religião do Candomblé, aquilo não é Umbanda, aquilo é uma religião que você está criando.

Dudu: É uma aculturação.

Odara: Eu acho que isso é uma apropriação falar que você faz uma coisa sendo que você faz outra. Distorce também.

Dudu: Roubo cultural.

Nesses últimos anos, a discussão sobre uso do turbante por mulheres brancas gerou debates sobre apropriação cultural e racismo, principalmente nas redes sociais. Em geral, se discute até que ponto as apropriações e usos de elementos da cultura africana por representantes da cultura dominante são prejudiciais ao (auto)reconhecimento da população negra. É importante mencionar que o turbante não é uma indumentária exclusivamente relativa aos povos africanos, sendo utilizado por outros povos como os indianos, islâmicos, entre outros. Não é utilizado, por esses povos, como simples adereço, mas como elemento simbólicoreligioso. No Brasil, além de símbolo religioso, o turbante é símbolo de resistência e empoderamento da população negra, sobretudo das mulheres negras.

A indústria cultural se apropria desse e de outros elementos transformando-os em produto de consumo e, o mais grave, sem reconhecer a população negra como autora dessas produções. A lógica do capital está interligada ao racismo e, através de sua lógica perversa, influi no sentido de aniquilar a identidade negra do terreno cultural, por meio de um processo homogeneizador de símbolos que marcam a diferença, colocando-os sob insígnia de brasilidade. Isso permite perceber o quão estrutural e racional é o racismo. Conforme salienta Souza (1994, p. 141):

[...] o racismo não é um movimento de simples anulação ou rejeição do outro. Ao mesmo tempo que repudia, quer igualar. [...]. Embora absurdo, há no racismo o projeto de se tornar o outro pelo igualamento da própria diferença que se pretende anular. $\mathrm{O}$ racismo revela-se assim, numa atitude manifesta de repúdio, vinculada a um fascínio latente.

Ao reivindicar a autoria dessas produções, a população negra é acusada de querer se apropriar de algo que faz parte da cultura nacional. A mesma ideologia "assimilacionista e miscigenacionista" (NOGUEIRA, 1954/2006), que em tempos anteriores lhe impôs o abandono de sua herança cultural em nome de uma "identidade nacional", espera agora que ela abra mão de sua autoria com relação aos seus símbolos culturais. A apropriação cultural desses elementos pode, de certo modo, aparecer travestida de incorporação cultural, como prova da ausência do racismo em nossas relações, reforçando o mito da democracia racial. Essa apropriação não decorre de reconhecimento da beleza da estética do corpo negro, é sim estratégia de dominação, 
pois na medida em que se apropria, mata os símbolos de resistência culturais, esvaziando seu significado.

Nas telas do cinema e da televisão, o corpo negro na dramaturgia hollywoodiana, era assexuado - como exemplo das "momys" negras interpretadas por atrizes que tinham de engordar e adquirir um sotaque sulista para satisfazer o estereótipo. O corpo masculino também era desvirilizado - interpretado como o bom preto velho, ora como "moleque". No Brasil, o corpo da mulher negra era hipersexualizado e objetificado, ou destituído de sexualidade, cabendo às mesmas sempre papéis secundários, como "criadas" fiéis da heroína branca. Tanto a cinematografia brasileira como, posteriormente, o gênero televisivo das novelas, sofreram forte influência do racismo explícito do Código Hays ${ }^{89}$ que, desde o fim da II Grande Guerra, regulavam as produções cinematográficas norte-americanas.

A identidade negra, enquanto uma construção social, é materializada, corporificada, visto que ser negro se relaciona a uma dimensão estética, para além do corpo. Elementos simbólicos, como o turbante, fazem parte da significação do espaço da corporeidade negra e da negritude. A apropriação indevida desses elementos provoca distorção de sua função simbólica na constituição dessa materialidade e corporeidade da identidade negra. Há uma desvinculação entre estética negra e seus simbólicos culturais, quando elementos marcadamente de origem africana e afro-brasileiros são exibidos nas propagandas em corpos brancos.

O mesmo efeito ocorre quando da utilização do prefixo "Afro" para designar a arte, cultura, literatura, entre outras produções negras. Cuti (2017) explica que esse uso é proposital visa esvaziar o conteúdo crítico e político das manifestações culturais da população negra. $\mathrm{O}$ autor argumenta que a palavra "negro," traduz a pessoa humana, remete a problematização das relações raciais e do racismo que devemos superar, ao contrário da palavra "Afro", a qual:

[...] não necessariamente, incorpora o fenótipo sobre o quão incide a insânia branca do racismo. Branca porque é dos brancos. Um "afro" pode ser branco. Há milhões deles. No "afro", o fenótipo negro se diluiu. É por isso que o jogo semânticoideológico tem se estabelecido e o sutil combate a palavra "negro" vem se operando, pois ela não encobre o racismo e, além disso, lembra reivindicações antirracistas. (CUTI, 2017, p. 198)

Um outro fato a ser problematizado é como o turbante ou o uso de tranças e penteados são vistos sob óticas distintas: quando estão presentes em corpos brancos, são reconhecidos

\footnotetext{
${ }^{89}$ Segundo Hirano (2015) o Código Hays foi implementado em 1934 “[...] internalizava a segregação racial nos Estados Unidos na forma cinematográfica, definiu as convenções do cinema hollywoodiano" (p. 142). Segundo o autor, esse Código proibia a referência à miscigenação a fim de desencorajar as relações inter-raciais. "A fabricação de corpos negros e brancos como antagônicos sinaliza o modo pelo qual o tabu da miscigenação se internalizava em diferentes níveis do cinema, buscando conformar noções de raça, corpo, gênero e sexualidade que mantivessem intacto o modelo de pureza racial norte-americana" (HIRANO, 2015, p. 153).
} 
como elementos da "moda", quando em mulheres negras, têm um sentido político de resistência e empoderamento, tornando-se, muitas vezes, elementos atenuantes de discriminação contra a pessoa negra que os utiliza. Para Pinheiro (2015, p. 04) pessoas e "[...] grupos que se utilizam desses elementos culturais inapropriadamente não só descaracterizam o simbolismo e a representatividade da cultura negra, como "roubam" desses grupos a autenticidade das práticas e do envolvimento político atrelado a elas".

O que torna o uso do turbante ofensivo aos grupos negros não se resume ao ato literal de usar, envolve o não conhecimento dos seus significados simbólico e político para a população negra (PINHEIRO, 2015). Além disso, como argumenta Odara, em alguns casos, a pessoa que utiliza é a mesma que discrimina, que não reconhece a beleza negra e não se abre ao diálogo ou ao questionamento de seu lugar de privilégio racial, nem dos efeitos do racismo na vida da população negra.

Além do turbante, os penteados como rastafári, tranças, etc., também têm sido exibidos nas mídias e redes sociais por artistas brancos. Segundo Gomes (2006), no Brasil o cabelo e o corpo são os elementos mais utilizados para classificação racial, o modo como ambos são compreendidos no imaginário social revelam especificidades das nossas relações étnico-raciais. A autora ressalta que "[...] o cabelo crespo é visto como um sinal diacrítico que imprime a marca da negritude nos corpos" (GOMES, 2006, p. 07), representa algo além de si próprio, constituindo-se uma forma de linguagem, posto que serve para leitura do social, por comunicar e informar sobre as relações raciais:

O cabelo do negro, visto como "ruim", é expressão do racismo e da desigualdade
racial que recai sobre esse sujeito. Ver o cabelo do negro como "ruim" e do branco
como "bom" expressa um conflito. Por isso, mudar o cabelo pode significar a tentativa
do negro de sair do lugar da inferioridade ou a introjeção deste. Pode ainda representar
um sentimento de autonomia, expresso nas formas ousadas e criativas de usar o
cabelo. O tratamento dado ao cabelo pode ser considerado uma das maneiras de
expressar essa tensão. A consciência ou o encobrimento desse conflito, vivido na
estética do corpo negro, marca a vida e a trajetória dos sujeitos. Por isso, para o negro,
a intervenção no cabelo e no corpo é mais do que uma questão de vaidade ou de
tratamento estético. É identitária. 90

O cabelo tem um significado social para o negro, a forma como ele o manipula é dotado de significação, expressa códigos que só podem ser interpretados pelos próprios negros e não por indivíduos de outros grupos. Na trama das relações étnico-raciais ambos, corpo e cabelo, são elementos da estética negra intensamente estigmatizados, constituem-se em marca de pertencimento racial e, por conseguinte, principais ícones identitários da população negra

${ }^{90}$ Ibid., p. 03. 
(GOMES, 2006). Isso é elucidado pela fala de Odara, para quem reconhecer-se como negro envolve reconhecer a estética negra:

Odara: [...] várias coisas porque se assumir como negro e ver que a estética preta é bonita, porque tipo todo mundo tem aquela ideologia: "Não, ele é um negro bonito, porque ele é um negro com traços finos". O traço fino que é um traço europeu, diferente é bonito, mas o traço negro, a boca grossa o nariz achatado é feio. Tipo se reconhecer como negro é perceber que o cabelo crespo é bonito e que os traços grossos, os traços negros, são bonitos também. E traz tudo isso.

Os discursos empreendidos desde a escravidão sobre o corpo negro tinham como função transformá-lo em espaço de validação do poder do branco (MONGA, 2010). A premissa era de destruição simbólica do corpo enquanto propriedade de si, para que ele não fosse mais sentido pelo próprio negro como algo que lhe pertencia. Assim, discursos foram forjados para animalizá-lo, destituí-lo de humanidade, desintegrá-lo e privá-lo de dignidade. Segundo Monga (2010), as morfologias corporais tornaram-se modos de categorização da alma, tentativa de frear na pessoa negra a consciência de si enquanto humano. Essa categorização tinha como intuito não só reduzir o significado do corpo, como reduzir a pessoa negra a uma ideia humilhante de corpo negro. No entanto, o corpo constituiu um dos mais importantes suportes de resistência negra, conforme assinala Rolnik (1989/2009, p. 76):

[...] um dos suportes mais sólidos desse repertório negro foi, desde a senzala, o próprio corpo, espaço de existência, continente e limite do escravo. Arrancado do lugar de origem e despossuído de qualquer bem ou artefato, era o escravo-portador - nem mesmo proprietário - apenas de seu corpo. Através dele que, na senzala, o escravo firmava e celebrava sua ligação comunitária; foi através dele, também, que a memória coletiva pode ser transmitida, ritualizada.

$\mathrm{Na}$ atualidade, observamos uma ressignificação da estética negra, evidenciada, entre outras formas, pela assunção do cabelo afro por parte de muitas mulheres negras, que por muito tempo foram levadas ao alisamento do cabelo como tentativa de se enquadrar aos padrões de beleza ditados pela branquitude. Dudu levanta um questionamento importante a esse respeito, ao assinalar que muitas mulheres podem assumir o cabelo crespo por uma questão de "modismo" e não com intuito de afirmação de identidade negra.

O problema, neste caso, seria a condição passageira do "modismo" de elementos pertencentes a estética negra, que poderiam ser abandonados tão rápido este passasse. Por outro lado, o simples fato de uma mulher negra não alisar seus cabelos nos parece, por si só, uma postura crítica, um indício de aceitação de sua negritude e passo importante no desdobramento de sua afirmação identitária.

Não podemos negar que o fato da representatividade e visibilidade nos meios de comunicação como propagandas publicitárias influenciam a assunção do cabelo crespo, no 
entanto é preciso considerar que uma maior visibilidade, e até mesmo consequente "modismo", seja fruto de ações empreendidas por mulheres negras, movimentos sociais, e não como resultante de um novo olhar do branco sobre a estética negra.

Assim, acreditamos que a maior parte das mulheres negras que hoje deixam de alisar seus cabelos, o fazem no sentido de resgatar sua autoestima, reconstruir uma autoimagem positiva, que lhes permita a afirmação de si para si, o que se mostra válido e importante, pois, ainda que preceda a consciência de um "tornar-se" negra, consiste em um dos reflexos de uma construção que tem se dado coletivamente pelo engajamento e lutas da população negra. Hall (2003, p. 341) alerta para o fato de que:

[...] como a cultura popular tem se tornado historicamente a forma dominante da cultura global, ela é, então, simultaneamente, a cena, por excelência, da mercantilização, das indústrias onde a cultura penetra diretamente nos circuitos de uma tecnologia dominante - os circuitos do poder e do capital. [...] Ela está enraizada na experiência popular e, ao mesmo tempo disponível para expropriação. Quero também defender a ideia de que isso é necessário e inevitável e vale também para a cultura negra, que, como todas as outras culturas populares no mundo, está destinada a ser contraditória [...].

Esse destino, entre apropriação e expropriação, consiste no fato de que, embora a cultura negra represente, no espaço da cultura popular, vozes de grupos socialmente estigmatizados, ela adentra o terreno da mercantilização, que torna suas experiências, representações e narrativas estereotipadas e submetidas ao controle das burocracias culturais. Segundo Hall (2003), para que a cultura negra, enquanto espaço de representação e contestação, possa ser palco de estratégias culturais críticas, a preocupação não deve se reduzir à definição do que é ou não negro. Ao passo que, agindo assim, acabamos por homogeneizar a experiência negra, desconsiderando o seu fazer no sentido dos efeitos de sua ação política, correndo o risco de valorizarmos “[...] pela inversão, a própria lógica do racismo que estamos tentando desconstruir" (HALL, 2003, p. 345).

A complexidade em torno da temática da apropriação cultural deve ultrapassar a definição do que é ou não negro, para se voltar à crítica que os grupos e movimentos negros vêm fazendo ao uso dos elementos africanos e afro-brasileiros pela lógica do capital, para que este uso não seja entendido como algo naturalizado e sem intencionalidade. Para Pinheiro (2015), é importante que grupos negros possam se perceber dentro do sistema capitalista, usufruindo de suas prerrogativas, ainda que muitas vezes, de forma estratégica e política, com a consciência de que dificilmente não terão seus elementos e práticas culturais categorizados e transformados em produtos de consumo. A reivindicação pela autoria e autenticidade desses elementos (repertórios culturais negros) dá-se muito mais por um fazer (experiência e 
expressividade negra), através do diálogo e da ação política, do que simplesmente pela oposição binária e apontamentos. Diante do posicionamento e empoderamento:

Não importa o quão deformadas, cooptadas e inautênticas sejam as formas como os negros e as tradições e comunidades negras pareçam ou sejam representadas pela cultura popular, nós continuamos a ver nessas figuras e repertórios, aos quais a cultura popular recorre, as experiências [contranarrativas e tradições] que estão por trás delas. (HALL, 2003, p. 342, acréscimo nosso)

Contudo, é preciso ver o lado positivo desse processo em que as culturas periféricas ganhem visibilidade no espaço da cultura popular. Pois, como assinala Hall (2003), ainda que esses espaços sejam policiados e a visibilidade se efetue de maneira regulada e segregada, não se trata "[...] simplesmente [de] uma abertura, dentro de espaços dominantes, à ocupação dos de fora. É também o resultado de políticas culturais da diferença, de lutas em torno da diferença, da produção de novas identidades e do aparecimento de novos sujeitos no cenário político e cultural $[\ldots]^{91 "}$.

Nessa mesma perspectiva, Gilroy (2007) fala sobre a emergência, na atualidade, de uma cultura visual negra, fruto do movimento político negro que empreendeu sua luta em torno da ideia revolucionária de beleza negra. Para o autor ainda que o arcabouço que circunscreve a negritude como sinônimo de brutalidade, crime, preguiça, entre outros, esteja intacto, essa cultura visual que imprime beleza à negritude questiona a ideia de "raça", na medida em que traz uma nova interpretação do corpo negro, ao permitir que ele seja simbolizado e imaginado de maneira diferente.

É como se essas imagens de beleza, graça e estilo não-brancas de alguma forma tornassem a questão da "raça" secundaria, em especial quando são iluminadas, filtradas e texturizadas e harmonizadas de modo a desafiar a percepção do observador, cada vez mais perplexo, sobre o possível lugar das fronteiras raciais. Neste cenário inquieto, criam-se novos ódios não pela imposição cruel de categorias raciais estáveis, mas por uma inabilidade perturbadora em mantê-las. (GILROY, 2007, p. 42).

Esse ódio pode ser percebido nas redes sociais, em que celebridades negras (da música, televisão, esportes, moda, etc.) sofrem ataques racistas. Esse tipo de comportamento de pessoas brancas pode ser compreendido como tradução do medo, consciente ou não, de que o corpo perca sua força na sustentação de fronteiras raciais mantenedoras de hierarquização social, pela qual são beneficiadas e privilegiadas. $\mathrm{O}$ racismo tende a se tornar cada vez mais exacerbado quanto mais ameaçadas forem essas fronteiras, o mínimo de desconfiança de que o corpo se desloca de sua função de determinar lugares na estrutura social provoca angústia em relação às hierarquias raciais mais antigas (GILROY, 2007). O racismo, racionalmente, atua não somente

${ }^{91}$ Ibid., p. 338, acréscimo nosso. 
para que as diferenças sociais sejam mantidas mas, sobretudo, para a anulação do outro como diferente. Se o corpo negro rebelado quer, de alguma forma, fugir à identidade rotulada, aspectos de sua cultura serão constantemente estereotipados e, por este caminho, requisitados para que ele retome a sua função de indicativo de pertencimento racial.

Para Gilroy (2007), esse momento coloca ênfase na cultura como uma propriedade relativa a determinado corpo, a fim de intensificar a relação entre diferenças culturais ${ }^{92} \mathrm{e}$ particularidades raciais. Segundo o autor, tal ênfase:

[...] confunde mais do que resolve os problemas surgidos da associação de "raça" com variações corporalizadas ou somáticas. De fato, precisamos ficar alerta para as circunstâncias em que o corpo é reinvestido do poder de arbítrio na atribuição de cultura às pessoas. Os corpos dos praticantes de uma cultura podem ser convocados para fornecer a prova sobre o lugar daquela cultura na hierarquia inevitável de valores. O corpo também pode prover as bases preeminentes onde essa cultura deve ser designa em termos étnicos. $\mathrm{O}$ corpo circula pouco à vontade através de discussões contemporâneas a respeito de que como se sabe o grupo a que se pertence e o que é preciso para alguém ser reconhecido como pertencente a uma dada coletividade. (GILROY, 2007, p. 47).

A diferença é tão central para a produção de nós mesmos quanto é para a produção e transformação de nossas identidades coletivas. A “[...] mudança só pode ser promovida pelo reconhecimento da diferença e pela produção subsequente de novas diferenças" (SOUZA, 1994, p. 39). A diferença perturba a ideia de identidade (em seu sentido fixo), ela não se presta a fundá-la, ela engendra seu movimento. Em virtude desse movimento que a diferença provoca, o sujeito está sempre se deslocando para ser, mas nunca um ser definitivo. Daí a pertinência do argumento de Hall (2000, p. 11) “[...] a identidade só pode ser lida a contrapelo, isto é, não como aquilo que fixa o jogo da diferença em um ponto de origem e estabilidade, mas como aquilo que é construído na diferença ou por meio dela [...]”.

\footnotetext{
${ }^{92}$ Para Bhabha (1998, p. 63, itálico do autor) “[...] diferença cultural é um processo de significação através da qual afirmações $d a$ cultura ou sobre a cultura diferenciam, discriminam e autorizam produção de campos de força, referência e aplicabilidade e capacidade".
} 


\section{EDUCAÇÃO ESCOLAR QUILOMBOLA NO QUILOMBO}

\subsection{Educação Escolar Quilombola}

Quando falamos de Educação Escolar Quilombola (EEQ), estamos nos referindo a uma modalidade emergente de educação, capaz de oferecer condições de contemplar as especificidades e particularidades de grupos quilombolas. Essa modalidade foi requerida pelos movimentos negro e quilombola, ainda no ano de 1995, durante o I Encontro Nacional Quilombola, por ocasião da Marcha Zumbi realiza pelo Movimento Negro em Brasília ${ }^{93}$. A partir desse ano, foram instituídas ações e se multiplicaram organizações importantes na defesa dos interesses das comunidades quilombolas, sobretudo no que diz respeito à educação. Em 1996 surgiu o CONAQ (Coordenação Nacional de Articulação das Comunidades Negras Rurais Quilombolas), importante entidade, composta pelos próprios quilombolas, cujo intuito era a mobilização e reivindicação de direitos ${ }^{94}$.

Em 2003 foi criado o Programa Brasil Quilombola, a fim de sistematizar ações que viessem a atuar não somente na questão da regularização fundiária de territórios quilombolas como também em questões de saúde e educação ${ }^{95}$. Nota-se que o crescimento das organizações em torno da demanda dessas comunidades teve como centro, sobretudo, a reivindicação de políticas públicas no campo da educação. Conforme pontua Nilma Lino Gomes:

$\mathrm{Na}$ agenda das lutas do movimento negro no Brasil, a questão quilombola foi se tornando cada vez mais marcante, com a participação de lideranças quilombolas que explicitavam a especificidade das suas demandas, sobretudo em torno de uma educação escolar que se realize em nível nacional e, de fato, contemple não só a diversidade regional na qual a população quilombola se distribui em nosso país, mas, principalmente, a realidade sócio-histórica, política, econômica e cultural desse povo. Uma realidade que tem sido invisibilizada ao longo da história da política educacional (BRASIL, 2011, p. 3).

\footnotetext{
${ }^{93}$ Esse encontro ocorreu entre 17 e 20 de novembro, dia em que o Movimento Negro, juntamente com outras organizações civis, organizaram em Brasília a "Marcha Zumbi dos Palmares contra o Racismo, pela Cidadania e pela Vida", em comemoração aos 300 anos de Zumbi.

${ }^{94}$ Não podemos deixar de mencionar a importância da Conferência Mundial contra o Racismo, à Xenofobia e às Intolerâncias Correlatas (Durban, 2001), nesse contexto de mobilização política de diversos setores sociais para o combate das desigualdades raciais.

${ }^{95}$ Esse Programa, lançado em 2004, está sob a coordenação da Secretaria de Políticas de Promoção da Igualdade Racial (Seppir). Aliado à Agenda Social Quilombola (Decreto $n^{\circ}$ 6.261/2007), articula-se em quatro eixos de ações: 1) acesso à terra; 2) infraestrutura e qualidade de vida; 3) inclusão produtiva e desenvolvimento local; e 4) direitos e cidadania. Cada um desses eixos envolve a implementação de outros programas governamentais. (SEPPIR- Programa Brasil Quilombola Diagnostico de Ações realizadas em 2012).
} 
Ainda no ano de 2003, houve a aprovação da Lei 10.639/2003, que alterou a Lei 9.394/96 de Diretrizes e Bases da Educação Nacional, para inserir e estabelecer a obrigatoriedade do ensino de História e Cultura Afro-brasileira e Africana na Educação Básica. A Lei $n^{\circ}$ 10. 639.03 representa mais uma vitória importante da população negra no que se refere à educação. De acordo com o Parecer do Conselho Nacional de Educação (CNE/CP 003/2004a) que trata das Diretrizes Curriculares Nacionais para a Educação das Relações Étnico-Raciais (DCNs para a ERER) e para o Ensino de História e Cultura Afro-brasileira e Africana, o Estado, enquanto responsável pela equidade social e garantia de direitos a todos os cidadãos, deve formular políticas reparatórias que possibilitem à população negra romper com o sistema meritocrático que resguarda privilégios ao grupo branco. Esse sistema relega ao grupo negro uma inclusão marginal dentro de uma sociedade que, há muito tempo, impõe desvalorização sistemática de sua história e cultura, e faz do sistema educacional um grande aliado na reprodução do racismo, e em seu fortalecimento enquanto mecanismo de produção de desigualdades sociais.

Na medida em que práticas e currículos escolares tem como objetivo oculto o de tornar o ambiente escolar um "não-lugar" para a pessoa negra, a eficácia do racismo reverbera na materialização desse "não-lugar", com a concreta confirmação da exclusão ou inclusão marginal da população negra em níveis superiores de ensino e, por conseguinte, na baixa escolaridade e qualificação profissional. Nesse sentido, as políticas de reparação voltadas para a educação devem se orientar para a superação do racismo e oferta de:

[...] garantias, a essa população, de ingresso, permanência e sucesso na educação escolar, de valorização do patrimônio histórico-cultural afro-brasileiro, de aquisição das competências e dos conhecimentos tidos como indispensáveis para continuidade nos estudos, de condições para alcançar todos os requisitos tendo em vista a conclusão de cada um dos níveis de ensino, bem como para atuar como cidadãos responsáveis e participantes, além de desempenharem com qualificação uma profissão. (BRASIL, 2004b, p. 11).

As ideologias arraigadas no imaginário social incidem de maneira diferente na trajetória de vida escolar e social de pessoas negras e não-negras. Por isso, a necessidade de construção de pedagogias de combate ao racismo que capacitem negros e não-negros a forjarem novas relações étnico-raciais ${ }^{96}$. No que diz respeito à Lei 10.639 e à educação quilombola, o Parecer CNE/CP 003/2004a prevê ações voltadas às comunidades remanescentes de quilombos que se alinhem ao movimento próprio da dinâmica das mesmas. Movimento esse caracterizado por

${ }^{96}$ Ibid., p. 238. 
um constante deslocamento no espaço e tempo, em que ocorreram transformações culturais e adaptações, tendo em vista a existência e sobrevivência desses grupos.

Nessa perspectiva, a “[...] implementação da lei em municípios onde há quilombos e em escolas quilombolas não vai ao encontro de um passado estático, que poderia credenciar o ato educativo com o "estatuto" de um ensino para 'cultura geral'. (BRASIL, 2006, p. 147). Assim, uma educação escolar quilombola deve considerar a articulação entre os saberes tradicionais e os saberes escolares, entre conhecimentos vividos e conhecimentos constituídos exigindo, portanto, uma nova forma de currículo e de práticas pedagógicas a fim de que não reproduzam uma estrutura social hierarquizada, voltada para conteúdos que colaboram para a consolidação do poder de determinados grupos sociais em detrimento de outros.

Repensar o currículo escolar é essencial, uma vez que em sua estrutura formal, tradicionalmente, não apenas exclui vozes de alguns grupos, como também está balizado em conteúdos escolhidos pelo grupo que detém o poder e que, por isso, decidi qual conhecimento deve estar incluso, qual deve ser excluído, e, portanto, qual conhecimento cultural e histórico é legitimo, ou não.

No ano de 2006, foram criados grupos de trabalho responsáveis pela elaboração do Plano de Ações para a implementação das Diretrizes Curriculares Nacionais para a Educação das Relações Étnico-raciais e para o Ensino de História e Cultura Afro-brasileira e Africana. Entre esses grupos se inclui o GT de Educação Escolar Quilombola, que elaborou um texto ressaltando a preocupação com a educação quilombola e sua relação com as relações étnicoraciais. O texto elaborado é parte integrante do Guia de orientações e ações para implementação da Lei 10.639/2003 (publicado pela SECADI), onde a referência à educação escolar quilombola é feita de maneira explícita e específica.

Vale ressaltar que esta Lei não faz uma referência explícita a essas comunidades, evocando as "[...] comunidades negras mais como objeto de interesse do que como público específico" (ARRUTI, 2017, p. 115). O texto acima citado se dirige às escolas quilombolas e àquelas que atendem quilombolas, alertando para a importância de se pensar e agir no sentido de construir políticas e práticas de educação que possam reconhecer as necessidades e as demandas desses grupos historicamente tratados como apartados da sociedade brasileira.

Entre 2009 e 2010 se intensificaram os debates em torno da elaboração de diretrizes curriculares nacionais e estaduais para a Educação Escolar Quilombola, por meio de seminários e audiências públicas nos níveis regionais e nacional. Como um desses encontros, houve, em 2010, a Conferência Nacional de Educação (CONAE), que culminou na escrita de um 
documento no qual são apresentadas "[...] orientações importantes a respeito da educação das relações étnico-raciais e da educação quilombola (BRASIL, 2011, p. 7). Nesse documento, questões relacionadas à diversidade, às diferenças e à educação são veemente afirmadas como necessárias para formação de uma escola verdadeiramente democrática, que venha a desempenhar sua função como agente ativo na superação das desigualdades sociais.

Especialmente em seu Eixo VI, "Justiça Social, Educação e Trabalho: Inclusão, Diversidade e Igualdade”, é enfatizada a importância de uma educação que dialogue com a pluralidade de grupos sociais; que reconheça as diversidades sexuais, de gênero, as pessoas com deficiências; que valorize a educação do campo, quilombola e escolar indígena, a educação profissional de jovens e adultos, sobretudo aqueles em situação de vulnerabilidade social. Nesse sentido, o documento alerta sobre as especificidades de cada grupo e, consequentemente, a necessidade de se pensar políticas públicas educacionais específicas para atendê-las.

Consta, ainda no documento, a menção da importância dos movimentos sociais “[...] tais como os movimentos negro, feminista, de pessoas lésbicas, gays, bissexuais, travestis, transexuais e transgêneros (LGBT), das pessoas com deficiência, do campo, indígena, quilombola, dos povos da floresta, das comunidades tradicionais" (CONAE, 2010, p. 129), como coletivos políticos identitários que, dentre outros, atuam de modo a problematizar e denunciar a falsa neutralidade das políticas educacionais, exigindo em suas ações de luta, que a escola venha a desempenhar sua função social na construção de novas mentalidades, livres de preconceitos e estereótipos. Com relação à EEQ, esse documento da CONAE delibera oito orientações principais:

a) Garantir a elaboração de uma legislação específica para a educação quilombola, com a participação do movimento negro quilombola, assegurando o direito à preservação de suas manifestações culturais e à sustentabilidade de seu território tradicional. b) Assegurar que a alimentação e a infraestrutura escolar quilombola respeitem a cultura alimentar do grupo, observando o cuidado com o meio ambiente e a geografia local. c) Promover a formação específica e diferenciada (inicial e continuada) aos/às profissionais das escolas quilombolas, propiciando a elaboração de materiais didático-pedagógicos contextualizados com a identidade étnico-racial do grupo. d) Garantir a participação de representantes quilombolas na composição dos conselhos referentes à educação, nos três entes federados. e) Instituir um programa específico de licenciatura para quilombolas, para garantir a valorização e a preservação cultural dessas comunidades étnicas. f) Garantir aos professores/as quilombolas a sua formação em serviço e, quando for o caso, concomitantemente com a sua própria escolarização. g) Instituir o Plano Nacional de Educação Quilombola, visando à valorização plena das culturas das comunidades quilombolas, a afirmação e manutenção de sua diversidade étnica. h) Assegurar que a atividade docente nas escolas quilombolas seja exercida preferencialmente por professores/as oriundos/as das comunidades quilombolas. (CONAE, 2010, p. 134). 
Ainda em 2010, tem-se a criação da Resolução CNE/CEB 04/2010 (BRASIL, 2010a) e do Parecer CNE/CEB 07/2010 (BRASIL, 2010b), que instituem as Diretrizes Curriculares Gerais para a Educação Básica, inserindo a Educação Escolar Quilombola como modalidade de ensino:

\begin{abstract}
A Educação Escolar Quilombola é desenvolvida em unidades educacionais inscritas em suas terras e cultura, requerendo pedagogia própria em respeito à especificidade étnico-cultural de cada comunidade e formação específica de seu quadro docente, observados os princípios constitucionais, a base nacional comum e os princípios que orientam a Educação Básica brasileira. Na estruturação e no funcionamento das escolas quilombolas deve ser reconhecida e valorizada sua diversidade cultural. (BRASIL, 2010b, p. 42).
\end{abstract}

Nesse mesmo ano, ocorre o I Seminário Nacional de Educação Quilombola, organizado pelo Ministério da Educação, através da Secretaria de Educação Continuada, Alfabetização, Diversidade e Inclusão (SECADI $)^{97}$. "Entre os objetivos desse seminário, destaca-se a construção de alicerces do Plano Nacional de Educação Quilombola e de subsídios ao CNE na produção das Diretrizes Curriculares Nacionais para a Educação Escolar Quilombola" (BRASIL, 2011, p. 8). Nesse contexto, segundo Arruti (2017, p. 116), as reflexões acerca da EEQ abrem espaço para que o reconhecimento das especificidades dos direitos quilombolas ultrapassem questões relativas à condição de vulnerabilidade social, abarcando também suas particularidades históricas, culturais, e demonstram o quanto considerações sobre elas são importantes na formulação de políticas de ação afirmativa pautadas nas diferenças.

\begin{abstract}
Ultrapassava-se, assim, o limite entre as chamadas "políticas de reconhecimento", ou seja, o conjunto de ações públicas elaboradas em atenção às especificidades das comunidades quilombolas, e as "políticas de redistribuição", ou seja, aquelas formuladas como simples extensão, como repasse diferenciado de recursos ou como reserva de uma cota especial no interior de políticas universais, cujo objetivo é corrigir uma situação de exclusão. [...] Ao lado de uma política fundiária diferenciada surge, assim, a proposição de uma educação diferenciada, que ultrapasse uma visão do outro que o reduz ao pobre, ao deficitário, ao dominado.
\end{abstract}

\title{
O “Texto -referência para a elaboração das Diretrizes Curriculares Nacionais para a
} Educação Escolar Quilombola” (BRASIL, 2011), do qual Nilma Lino Gomes foi relatora, também faz parte do conjunto de textos sobre a discussão e elaboração de Diretrizes Curriculares para a Educação Quilombola. Parte do texto é dedicado à definição de quilombos. Em 2012, a autora foi também relatora do Parecer CNE/CEB, no 16/2012a - Diretrizes Curriculares Nacionais para a Educação Escolar Quilombola, homologado em 20 de novembro de 2012. Com a homologação desse Parecer, é regulamentada a Resolução $\mathrm{n}^{\circ}$ 8, de 20 de

\footnotetext{
${ }^{97}$ Criada em 2004, importante para institucionalização da discussão sobre educação Escolar Quilombola (GOMES, 2011).
} 
novembro de 2012, que define as Diretrizes Curriculares Nacionais para a Educação Escolar Quilombola na Educação Básica. No ano seguinte é publicado o Plano Nacional de Implementação das Diretrizes Curriculares Nacionais para a Educação das Relações Étnicoraciais e para o Ensino de História e Cultura Afro-brasileira e Africana (BRASIL, 2013a), no qual constam ações para a educação em áreas remanescentes de quilombos:

\begin{abstract}
a) Apoiar a capacitação de gestores locais para o adequado atendimento da educação nas áreas de quilombos; b) Mapear as condições estruturais e práticas pedagógicas das escolas localizadas em áreas de remanescentes de quilombos e sobre o grau de inserção das crianças, jovens e adultos no sistema escolar; c) Garantir direito à educação básica para crianças e adolescentes das comunidades remanescentes de quilombos, assim como as modalidades de EJA e AJA; d) Ampliar e melhorar a rede física escolar por meio de construção, ampliação, reforma e equipamento de unidades escolares; e) Promover formação continuada de professores da educação básica que atuam em escolas localizadas em comunidades remanescentes de quilombos, atendendo ao que dispõe o Parecer 03/2004 do CNE e considerando o processo histórico das comunidades e seu patrimônio cultural; f) Editar e distribuir materiais didáticos conforme o que dispõe o Parecer CNE/CP n ${ }^{\circ}$ 03/2004 e considerando o processo histórico das comunidades e seu patrimônio cultural; g) Produzir materiais didáticos específicos para EJA em Comunidades Quilombolas; h) Incentivar a relação escola/comunidade no intuito de proporcionar maior interação da população com a educação, fazendo com que o espaço escolar passe a ser fator de integração comunitária; i) Aumentar a oferta de Ensino Médio das comunidades quilombolas para que possamos possibilitar a formação de gestores e profissionais da educação das próprias comunidades.( BRASIL, 2013a, p. 57-58).
\end{abstract}

As DCNs para a EEQ têm a função de orientar e criar subsídios para a implementação da Educação Escolar Quilombola nas várias etapas (Educação Infantil, Ensino Fundamental, Ensino Médio) e modalidades (Educação do Campo, Educação Especial, Educação Profissional Técnica de Nível Médio, Educação de Jovens e Adultos, inclusive na Educação à Distância) da Educação Básica. No âmbito dessa norma, a EEQ se destina às comunidades quilombolas rurais e urbanas, devendo ser ofertada pelos estabelecimentos públicos de ensino localizados no interior dessas comunidades, assim como em escolas próximas que atendam alunos oriundos desses territórios.

No que se refere à relação entre educação e quilombos, cabe ressaltar que há extensos territórios quilombolas que possuem escolas em seu interior e áreas em que jovens e adultos dessas localidades migram temporária ou efetivamente para estudar nas cidades de suas regiões (BRASIL, 2006, p. 142).

De acordo com os dados disponíveis no Censo Escolar 2016 ${ }^{98}$, existem 186,1 mil escolas de Educação Básica, sendo que, deste total, 2,369 estão situadas em áreas remanescentes de

\footnotetext{
98 Trata-se de um levantamento de dados sobre o sistema educacional brasileiro, realizado anualmente sob a coordenação do Instituto Nacional de Estudos e Pesquisas Educacionais Anísio Teixeira (INEP). O censo escolar apresenta resultados relativos à Educação Básica, considerando número de escolas, matrículas, informações sobre a localização e infraestrutura das escolas. No ano de 2004, foi incluída no censo escolar a categoria "escolas situadas em áreas remanescentes de quilombos", dando visibilidade a escolas quilombolas. Segundo Arruti (2017,
} 
quilombos com cerca de 241.925 matriculados. Não encontramos no referido censo informações mais precisas sobre a EEQ, como números de escolas por níveis de ensino, há somente dados relativos ao número de creches no interior das comunidades quilombolas (714 ao total). Com base no documento Educação escolar quilombola no Censo da Educação Básica (IPEA, 2015), elaborado por Tatiana Dias Silva a partir dos dados Censo Escolar (2013), as escolas quilombolas representam:

[...] apenas $1,2 \%$ do total de estabelecimentos de educação básica no país e apenas $0,45 \%$ das matrículas neste nível. Concentram-se na região Nordeste - condizente com a porcentagem de comunidades certificadas nesta região $(63,7 \%)-\mathrm{e}$ em estabelecimentos municipais, em geral responsáveis pelas etapas inicias da educação básica. Apenas 135 estabelecimentos $(6,0 \%)$ estão localizados na área urbana, concentrando 21,2\% das matrículas. (SILVA, 2016, p. 16).

A autora apresenta um número de 2.235 estabelecimentos de ensino em comunidades quilombolas. Segundo ela, essas escolas situam-se, em sua maioria, nos estados de Maranhão, Bahia, Pará e Minas Gerais, justamente onde se concentram maior quantidade de comunidades remanescentes de quilombos ${ }^{99}$. Com base no número de escolas que declararam trabalhar com material específico para educação sociocultural quilombola ${ }^{100}$, a autora expõe, ainda, que cerca de 552 escolas, exteriores a áreas de quilombo recebiam alunos oriundos dessas comunidades. No entanto, ela alerta que esses números não são precisos, pois é provável que, por um lado, algumas escolas quilombolas não tenham se declarado como tais e, por outro, parte das escolas que se declararam quilombola poderiam não estar fazendo uso do material didático específico.

p. 126): “Inexistentes em 2003, depois que surgiram, no Censo Escolar de 2004, em número de 298, elas cresceram quase $250 \%$ em dois anos e seguiram crescendo vigorosamente nos anos seguintes, ainda que em um ritmo bem menor e muito irregular. [...] Da mesma forma, as cerca de 22.800 matrículas quilombolas de 2004 crescem cerca de 23,3\% nos dois anos seguintes (alcançando pouco mais de 75.300 alunos matriculados em 2006)". O autor menciona que esse crescimento não se relaciona a um crescimento vegetativo da população quilombola, mas à visibilidade política em nível nacional que, entre outras, possibilita a conscientização de alguns gestores e consequente atitude destes em classificar a escola em que atua como localizada em áreas de quilombos. No entanto, esse instrumento não permite contabilizar o número de alunos quilombolas que frequentam escolas fora de sua comunidade.

99 Existem comunidades remanescentes de quilombos em quase todos os estados brasileiros, exceto no Acre, Roraima e no Distrito Federal.

100 A elaboração de material didático específico para alunos e professores da Educação Básica, de escolas localizadas em comunidades remanescentes de quilombos ou em escolas situadas fora destas áreas, mas que atendam alunos provenientes dessas comunidades, fica a cargo do Programa Nacional de Educação no Campo (PRONACAMPO - instituído pelo Decreto $\mathrm{n}^{\circ}$ 7.352, de 4 de novembro de 2010). O programa também é responsável pelo acesso e recuperação da infraestrutura, qualidade da educação quilombola, e pelo Pronatec Campo, que contempla formação de professores em Educação Escolar Quilombola, formação profissional para trabalhadores e jovens, implantação do programa Mais Educação, financiamento de pesquisas e expansão de cursos em Universidade Aberta do Brasil para atendimento de educadores do campo e da educação quilombola. (SEPPIR, 2012). 
Arruti (2017) também faz algumas ponderações sobre números e conceitos relativos à educação escolar quilombola que devemos levar em consideração quando pensamos em estatísticas numéricas provindas de dados oficiais que procuram, por sua vez, dimensionar o número de escolas quilombolas e de estudantes atendidos seja em escolas presentes no interior, ou fora de comunidades quilombolas. A escola pode constar como quilombola nos censos escolares sem que haja uma educação diferenciada que, de fato, corresponda a uma "Educação Escolar Quilombola", uma vez que as escolas são compreendidas como "quilombolas" apenas por se situarem em terras assim identificadas. Por outro lado, segundo o autor, pode haver escolas no interior de quilombos que não recebam apenas alunos dele oriundos, assim como pode haver casos de escolas de fora de áreas quilombolas que atendam principalmente alunos vindos dessas comunidades.

Arruti (2017) acrescenta um outro fator que pode implicar em imprecisões e interferência em dados reais, especificamente o fato de caber ao gestor da escola a classificação da escola em "área de quilombo", quando do preenchimento do Censo escolar; pode acontecer uma divergência entre a classificação realizada por ele e a auto atribuição da comunidade em que a escola está inserida. Isto nos coloca frente a um impasse, na medida em que essa classificação pode:

[...] não se dar nem por auto-atribuição da comunidade, nem pelo reconhecimento prévio e oficial dessa comunidade e de seu território pelo Estado brasileiro, mas pelo conhecimento, avaliação, reconhecimento ou mesmo adesão ou oposição deste(a) gestor(a) em relação à classificação étnica, cultural e política da comunidade ou bairro em que a sua escola está situada, o que implica, quase sempre, uma tomada de posição política por parte deste funcionário público ${ }^{101}$.

Com relação a essas contradições, o autor considera que há situações em que alguns municípios solicitaram reconhecimento de comunidades sem que essas fossem previamente consultadas, com intuito de recebimento de recursos (materiais ou imateriais), que podem ser adquiridos pelo status quilombola. Em outros casos, como relata o autor, os gestores de algumas escolas urbanas de Salvador as estariam cadastrando no Censo escolar como quilombolas não em função de um “[...] 'erro' classificatório, mas de uma divergência resultante da forma pela qual o processo de ressemantização do termo quilombo foi operado naquele contexto social, cultural e institucional"102. Esse caso, segundo Arruti (2017), seria resultado de uma atitude militante por parte dos gestores, influenciados pelo forte ideário quilombola de Salvador e pela

\footnotetext{
${ }^{101}$ Ibid., p. 120.

${ }^{102}$ Ibid., p. 121
} 
forte expressão identitária da palavra quilombo nesses bairros pobres e de maioria negra em que as escolas se inseriam.

No caso da escola em questão, o contrário fica evidenciado. Há, entre os moradores, uma compreensão pejorativa do termo quilombo, o que impede, entre outros fatores, a autoidentificação da comunidade para além do âmbito legal. Desse modo, a classificação da escola ainda não encontra correspondência na comunidade, ou seja, boa parte dos moradores não se autoidentificam como quilombolas, embora a comunidade esteja oficialmente certificada como tal. ${ }^{103}$ Logo após a comunidade Barro Preto ser certificada pela Fundação Cultural Palmares houve uma mobilização da gestão escolar para que a escola viesse a se tornar quilombola de fato e de direito. Passaremos, então, a discorrer sobre esse processo e os desafios encontrados durante essa transição e trajetória, assim como o papel social da escola na construção da identidade quilombola entre os moradores dessa comunidade.

\subsection{Vicissitudes de uma escola no processo de tornar-se uma escola quilombola}

Segundo informações obtidas com a diretora, que atua nessa unidade de ensino desde 2007, com a mudança à categoria de escola quilombola houve a necessidade de realizar ações direcionadas à ressignificação da concepção da escola que envolveram, em um primeiro momento, a elaboração de um Projeto Político Pedagógico (PPP) condizente com a proposta de EEQ. Assim, entre 2007 e 2010, a gestão escolar buscou apoio de instituições que pudessem auxiliar e instrumentalizar a escola para a construção desse Projeto Pedagógico. Entre as instituições procuradas, destacam-se o Órgão de Educação e Relações Étnicas (ODERE) da Universidade Estadual do Sudoeste da Bahia (UESB), e o Instituto de Educação Anísio Teixeira. As gestoras realizam vários cursos de formação relacionados às relações étnico-raciais e, especificamente, em um curso de gestão escolar trabalharam na confecção do PPP da escola:

Maria (vice-diretora): Com o reconhecimento, a gente se preocupou logo com o projeto político porque não tinha projeto e a gente precisava sustentar o que a gente

\footnotetext{
103 “.... Comunidades Certificadas são aquelas que possuem processo aberto na Fundação Cultural Palmares e atenderam às exigências do Decreto $n^{\circ} 4.887 / 2003$ e da Portaria 98, de 26/11/2007, que determinam os procedimentos para emissão da Certidão de Autorreconhecimento" (BRASIL, 2011, p. 26). Esse decreto determinou a responsabilidade pela certificação das comunidades quilombolas, à Fundação Cultural Palmares. A partir dessa certidão, as comunidades são incluídas na lista de políticas públicas, geralmente gerenciadas pelo Programa Brasil Quilombola. De acordo com a Fundação Cultural Palmares, são cerca de 2.526 comunidades certificadas de um total de 3.010. Os Estados com mais comunidades quilombolas são também aqueles com maior número de certidões emitidas: Bahia, 619 certificadas de um total de 743, Pará, 197 de um total de 254, Maranhão, 507 de um total de 689, Minas Gerais, 247 de um total de 313. Disponível em: <http://www.palmares.gov.br/file/2017/09/QUADRO-DE-COMPARATIVO-DECERTIFICA\%C3\%87\%C3\%95ES-ANUAIS-09-2017.pdf>
} 
estava falando e fazendo. Então, o primeiro projeto foi feito, mas basicamente em uma fonte de estudo da gestão, depois que ele foi elaborado a gente teve a segunda parte dos projetos que foi feito com os professores. Partindo daquele que já estava feito foi mais fácil para o professor. Tentamos fazer com o professor, mas não conseguimos. Ninguém sabia o que era um projeto político, ninguém sabia o que era para escrever, ninguém sabia qual era a meta, qual era a ação. E aí eu e Manuela, nós entramos em uma especialização de gestão escolar e colocamos como nosso TCC o projeto político pedagógico da escola. Aí, a gente conseguiu fazer com a comunidade, porque o curso durou dois anos e cada disciplina tinha que fazer uma parte do PPP e tinha que fazer com a comunidade. Então, quando terminamos o curso o projeto político estava pronto, feito com a comunidade, com os professores, com os estudantes, com o colegiado. O colegiado escolar é formado por professores, estudantes, funcionários e representante da comunidade. Então, a gente tem um projeto político feito realmente com a comunidade.

O depoimento de Maria evidencia que houve uma preocupação na elaboração de um projeto político-pedagógico em conformidade com o que as Diretrizes determinam: “[...] ser construído de forma autônoma e coletiva mediante o envolvimento e participação de toda a comunidade escolar", em processo dialógico que envolva as pessoas da comunidade e as instituições de Ensino Superior, a fim de que se possa garantir a "[...] construção de um currículo escolar aberto, flexível e de caráter interdisciplinar, elaborado de modo a articular o conhecimento escolar e os conhecimentos construídos pelas comunidades quilombolas, referendado em um projeto político-pedagógico, que considere as especificidades históricas, culturais, sociais, políticas, econômicas e identitárias das comunidades quilombolas" (BRASIL, 2012; 2013b, p. 12).

Versa, ainda, nas referidas DCNs EEQ (nacionais e estaduais) que a organização do currículo pode ser feita por meio de eixos temáticos, projetos de pesquisa ou temas geradores que contemplem discussões em torno da identidade, cultura, movimento negro e quilombola no Brasil e na Bahia, buscando-se promover o fortalecimento da identidade étnico-racial, da história e cultura afro-brasileira e africana. Nessa perspectiva, segundo relato da depoente, a organização do PPP, que ocorreu entre os anos de 2008 e 2010, deu-se através de temas organizadores. Entre 2007 e 2008, o primeiro tema gerador, "Reorganização Estrutural da Escola", teve como proposta a construção de uma identidade coletiva para a escola. Nesse período, foi realizada uma pesquisa diagnóstica com a comunidade escolar, em que se verificou certa dificuldade de assumir o pertencimento à comunidade e problemas ligados à ausência de autoestima.

Sendo assim, com o intuito de ressaltar a ancestralidade e elevar a autoestima, entre 2009 e 2010, o tema gerador foi "Nascer negro é consequência, ser negro é consciência", tendo como abordagem a contribuição histórica da população negra nos contextos brasileiro, baiano e jequiense, em particular no contexto de formação da comunidade de Barro Preto. Entre 2011 
e 2012, o tema gerador foi "Saberes \& Saberes", voltado ao estudo do continente africano e seus saberes articulados aos saberes e luta do movimento negro e quilombola na Bahia e no Brasil. Concomitantemente aos temas geradores, foram sendo realizadas atividades ligadas a oficinas.

Em 2010, a escola foi ganhadora do Selo de Educação para a Igualdade Racial, pelo trabalho realizado através do projeto intitulado "Beleza Negra", cujo intuito foi promover a elevação da autoestima de alunos(as) negros(as). A diretora da escola, Manuela, enfatiza que esse projeto foi direcionado, principalmente, para as meninas negras, grupo majoritário entre os estudantes da escola - "[...] o cabelo era um detalhe que as mulheres mais rejeitavam para elevação da sua autoestima, a cor da pele nem tanto, mas o cabelo...”. Esse projeto teve como base oficinas de: “... maquiagem, de cabelo de turbante, de trança, desfile da beleza negra e aí começamos a trabalhar com autoestima da mulher negra e colocamos a história da cultura afro-brasileira [...]".

Após a realização do curso de gestão escolar e encontros que envolviam a discussão da temática, a mudança do nome da escola, Colégio Estadual Duque de Caxias, passou a ser uma preocupação. A escola foi fundada no ano de 1964 com o nome de Grupo Escolar Duque de Caxias, nome atribuído em homenagem ao militar e estadista Luís Alves de Lima e Silva, conhecido como "Duque de Caxias". Assim, no ano de 2011, foi feita uma eleição interna na escola para que seu nome pudesse ser modificado, conforme ressalta a vice-diretora:

\footnotetext{
Maria: O nome dessa escola era Duque de Caxias, também nesse processo de reconhecimento quilombola a gente estudou a história de Duque de Caxias e a gente viu que não tinha nada a ver. Então, a gente foi em um congresso em Salvador e lá o pessoal: "Não, Duque de Caxias colocou o negro na trincheira, lá na linha de frente, prometendo a eles a alforria e na verdade eles foram para o matadouro. Como é que uma escola que tem uma proposta dessa tem como nome Duque de Caxias?" E aí foi outra luta "Por que, como é que faz para mudar o nome se a comunidade reconhece como Duque de Caxias?" Aí, foi uma luta para mudar o nome, a gente fez uma pesquisa aqui dentro da escola, para votos, colocamos alguns nomes: Abdias do Nascimento, tinha Nelson Mandela, Mãe Menininha do Gantois, Zumbi dos Palmares, o próprio Milton Santos e até Nelson Mandela entrou. Todo mundo votou. Fizemos uma votação aqui dentro da escola e pasme você...E a gente colocou também Duque de Caxias, porque a gente não poderia tirar...Aí, pasme você... Duque de Caxias ia ganhar... Aí, eu falei: "Manuela o que a gente vai fazer, Duque de Caxias vai ganhar?" (risos). Aí, a gente começou aquele trabalho, sabe?... De explicar mesmo a importância de Duque de Caxias para aquele momento do Brasil, o nome foi dado para a escola porque naquele momento servia, era um bom representante para a escola naquele momento, período, mas que agora já não era mais e que a gente precisava de alguém que tivesse a nossa cara. E aí ganhou Milton Santos.
}

Segundo a depoente, foi preciso um longo trabalho de conscientização, em que a origem e história de cada personagem histórico proposto para votação foi contextualizado e socializado, 
para que a maioria não optasse pela manutenção do nome "Duque de Caxias"104. A mudança de nome ocorreu quatro anos após o reconhecimento da Comunidade de Barro Preto, pela Fundação Palmares. Na primeira ida ao campo de pesquisa, ao buscar referências para chegar à escola, podemos verificar que as pessoas, quando indagadas sobre o quilombo, já o identificam como tal. No entanto, quando indagados sobre a localização da escola "Professor Milton Santos" ainda se referem a ela como "a antiga Duque de Caxias".

Pedro conta, com entusiasmo, as mudanças ocorridas na escola, ao ser reconhecida como quilombola, ressaltando a mudança do nome da escola:

\begin{abstract}
Pesquisadora: Houve mudanças depois que ela se tornou uma escola quilombola? Pedro: Mudou tudo, em todos os aspectos. Primeiro o nome... O que Duque de Caxias fez, patrono do exército brasileiro, fez o que pela nossa Bahia, pelos estudantes? Que eu saiba nada. Já que o colégio é quilombola colocou um professor negro, entendeu? O nome já tirou logo, tirou Duque e colocou Milton Santos, é só clicar na internet e pronto, em quinze a vinte linhas você vai descobrir quem é ele, já melhorou. E aí teve reforma, as apresentações que elas fazem. Em todos os aspectos aquele colégio melhorou para caramba, sem por cento ali melhorou. A cultura ali rola solta, sempre tem exposições. Tudo que é feito no colégio, no meio e no fim do ano, tem exposições. É na feira cultural, onde apresenta tudo o que foi feito no colégio. Outra coisa, o aluno entrou para dentro do colégio só sai no último horário, se tiver necessidade liga para o pai e ele vai buscar. Porque tem alunos que simulam que estão passando mal.
\end{abstract}

Além da mudança do nome, após seu reconhecimento como escola quilombola, a escola adquiriu verbas para reforma e compra de materiais (computadores, jogos, livros, entre outros. A escola adota um cardápio quilombola, estando de acordo com as orientações das DCNs para EEQ em que consta a garantia de alimentação escolar voltada para as especificidades socioculturais da comunidade (BRASIL, 2012b). O incentivo para a alimentação das escolas quilombolas fica a cargo do Programa Nacional de Alimentação Escolar (PNAE), que repassa aos municípios um valor de $\mathrm{R} \$ 0,34$ por aluno matriculado. Ainda segundo as DCNs para EEQ, com relação à alimentação, é importante que [...] os sistemas de ensino e suas escolas contratem profissionais de apoio escolar oriundos das comunidades quilombolas para produção da alimentação escolar, de acordo com a cultura e hábitos alimentares das próprias comunidades".

${ }^{104}$ Duque de Caxias foi um dos militares responsáveis por massacres realizados na Guerra do Paraguai (18641870) e no chamado "Massacre de Porongos" ou "Traição de Porongos" (novembro de 1844), que assassinou cerca de 600 a 700 negros. O Massacre recebeu esse nome, pois ocorreu em Porongos (hoje município de Pinheiros Machado no Rio Grande do Sul). Os lanceiros negros eram recrutados para lutar contra o governo imperial, na chamada Revolução Farroupilha em troca de liberdade. Após dez anos de conflito, houve um acordo de paz entre o governo imperial e os líderes farrapos. No entanto, os lanceiros foram traídos pelos farroupilhas e entregues ao governo imperial, que os queria manter em condição de escravidão. Convocados para uma homenagem onde acreditavam que receberiam suas alforrias, os lanceiros negros foram covardemente assassinados pelas tropas imperiais, sob a ordem de Duque de Caxias (Francisco Pedro de Abreu). Este assassino, assim como vários outros, recebeu diversas homenagens, há ruas, praças, escolas, estações, bairros que receberam o seu nome, além disso é tido como patrono do Exército Brasileiro. Cf. Maestri Filho, Mário José. O escravo gaúcho: resistência e trabalho. Editora Brasiliense, 1984. 
As pessoas que preparam o alimento nesse contexto escolar são oriundas da comunidade. No depoimento abaixo Maria, uma das gestoras da escola, fala sobre o cardápio que seria servido naquele dia em que estávamos conversando, uma quarta-feira:

\begin{abstract}
Manuela: Toda quarta feira serve vatapá, frango arroz e salada, para que os meninos possam conhecer um pouco mais sobre a alimentação. Nós tínhamos um projeto esse ano sobre alimentação com redução dos alimentos industrializados porque eles comem muito salgadinho com isso houve um aumento enorme da pressão arterial, entre eles. Teve uma aluna aqui que passou mal quando chegou no hospital estava com pressão de dezessete. Então a gente tem esse cuidado e os projetos estão sempre voltados para necessidades que a gente percebe dentro da escola
\end{abstract}

Segundo relato da diretora da escola, houve ainda outra mudança importante, que consistiu na substituição do ensino do EJA pelo ensino médio regular. A justificativa da mudança foi de que os alunos que frequentavam essa modalidade de ensino acabavam por evadir, enquanto aqueles que terminavam o ciclo fundamental não davam prosseguimento aos estudos, por não se sentirem estimulados devido à ausência do ensino médio nesse espaço escolar. Outro fator agravante, segundo a diretora, seria a dificuldade dos profissionais da educação em efetivar o EJA, de maneira organizada e planejada:

\begin{abstract}
Manuela: Gosto muito da metodologia da EJA, mas ela não era trabalhada... Não era não, não é trabalhada de forma como ela foi planejada. E o planejamento da EJA é muito eficaz, mas sua prática não sei lhe dizer porque não conheço nenhuma escola que colocou em prática aquilo que nossos mestres em educação escreveram. Porque para eu dizer que não dá certo aquilo que está escrito tem que entrar em ação, né? [...] Depois que ele entra em ação é que eu faço as modificações. E ninguém trabalha com a EJA de forma organizada, entendeu? E quem era o estudante da EJA que chegava na nossa escola? O que não queria nada. Aí eu falei: "Não, a nossa escola não é uma escola para quem não quer nada, senão vai identificar de novo o negro como marginal". Então, infelizmente eu vou ter que tirar o EJA". Aí, eu lutei para trazer primeiro o ensino médio para cá, porque quando eu vim para cá não tinha o ensino médio.
\end{abstract}

Manuela observa que a inserção do ensino médio na escola poderia servir de estímulo aos alunos oriundos do bairro para concluírem o ensino médio regular. Há, em seu depoimento, uma associação entre valorização, continuidade dos estudos e rompimento de estigma relacionado à população negra e à comunidade.

No PPP da escola há referência aos impactos da marginalização do bairro majoritariamente composto por negros (as) - na autoestima dos seus habitantes. O preconceito e a discriminação vivenciados no contexto social são aspectos que acabam por influenciar na autoestima e, por conseguinte, no rendimento escolar e na motivação para estudar. Segundo o documento, grande parte dos moradores em idade produtiva estão desempregados, atuando em mercado informal, ou entregues a ações ilegais. Apenas $20 \%$ da população recebe um pouco 
mais de um salário mínimo. Essas evidências demonstram um processo de exclusão em curso, ocasionada pela hierarquia estabelecida pelo sistema social, em que instituições econômicas, sociais e políticas, com contribuição expressiva dos veículos midiáticos asseguram o poder ao grupo branco da população brasileira. A redução do grupo negro a condições de marginalidade e criminalidade mina seu poder de reação à violência racial a que é exposto cotidianamente.

Essa violência racial modela as condições de vida de tal forma que, muitas vezes, os estereótipos acabam sendo confirmados pela observação das reais situações de vida dessa população. A acumulação de uma desvantagem histórica com relação à educação para os negros, ocasionada pelo racismo institucionalizado em nossa sociedade, acaba por acarretar uma desvalorização da escolarização, levando parte deles a abandonarem a escola, o que resulta em uma real situação de baixa escolarização, comparativamente com a população branca ${ }^{105}$. Essa real situação reforça o estereótipo de que o negro tem pouco ou nenhuma instrução, fato que resulta em mais discriminação, baixo investimento na educação por parte da própria população negra, que não se vê representada socialmente em determinadas posições e profissões, e desculpa para o baixo investimento na educação, por parte do governo

Para Rosemberg (2017) o racismo brasileiro é mantido e reproduzido pelas instituições nos âmbitos simbólico e material. Nesse sentido, segundo a autora, não se restringe às relações interpessoais, não é resquício ou legado da escravidão, mas, perspicaz e atuante, se faz presente nas práticas de discriminação institucional: "Ao alocarem verbas insuficientes para a creche pública de qualidade, mesmo que não seja uma ação específica contra negros, haverá um impacto na manutenção das desigualdades materiais/estruturais e simbólicas contra negros". (ROSEMBERG, 2017, p. 132). A autora ressalta a importância da educação no combate ao racismo através do resgate da autoestima das pessoas negras, o que implica na desconstrução de estigma a partir da conscientização das reais causas da situação de exclusão que acomete esse segmento social. Relacionando desconstrução de estigma à educação quilombola, a implantação dessa modalidade de educação "[...] insere-se no conjunto mais amplo de desestabilização de estigmas que definiram, ao longo de nossa história, a inserção subalterna

\footnotetext{
${ }^{105}$ A pesquisa intitulada Desenvolvimento Humano para Além das Médias, realizada em 2017, revelou o abismo educacional entre negros e brancos: com relação ao ensino fundamental completo, da população acima de 18 anos, $62 \%$ da população branca ante $47 \%$ da população negra; no ensino superior, da população entre 18 a 24 anos, 42,63 são brancos ante 19,14 negros. A mesma pesquisa revelou que a diferença na expectativa de vida ao nascer entre brancos e negros era de 2 anos, respectivamente 75,3 anos e 73,2 . Com relação à pobreza extrema 3,33 brancos ante 9,46 negros. O estudo revelou, ainda, que a renda per capita da população branca é mais que o dobro da população negra $\mathrm{R} \$ 1.097,00$ ante $\mathrm{R} \$ 508,90$. Disponível em: < http://www.br.undp.org/content/dam/brazil/docs/IDH/desenvolvimento-alem-das-medias.pdf> Acesso em: 15 nov. 2017.
} 
da população negra na sociedade e, consequentemente, no sistema escolar. (MIRANDA, 2012, p. 374).

A ausência ou uma ferida profunda na autoestima dificulta, sobretudo, a formação de uma identidade étnico-racial positiva. A identidade racial relaciona-se ao modo com que o indivíduo se compromete e se articula com suas matrizes étnico-raciais. Assim, uma identidade racial positiva, ou seja, o desenvolvimento do valor de si, se estabelece quando o sujeito se referenciar positivamente no grupo étnico-racial do qual descende. Nesse sentido, ressaltamos o importante papel da escola na desconstrução da visão estereotipada da comunidade de Barro Preto como essencial para o desenvolvimento de identificação racial positiva dos membros dessa comunidade.

$\mathrm{Na}$ fala das gestoras entrevistadas, esse desafio só poderia ser enfrentado através do rompimento com o modo com que a escola era percebida pelos próprios alunos - como espaço marginalizado, sem perspectiva de afirmação social. Segundo o relato a seguir, os episódios de violência entre os estudantes diminuíram após uma mudança de postura da gestão, quando se passou a dar voz aos alunos e a compreender a problemática que envolve a comunidade na qual se inserem. O depoimento de Maria, vice-diretora, foi obtido após ter sido indagada sobre qual o reflexo das atividades desenvolvidas na escola na vida dos alunos:

[...]Eu acho fantástico. Eu cheguei aqui em 2005 e hoje eu estou sentada conversando contigo e ninguém me chamou, ninguém brigou e nem quis matar ninguém... Eu acho que é fantástico, é isso que me faz levantar todo dia cedo e vir para esta escola, porque eu sei que o caminho está certo. As mudanças são muito grandes, e eu falo assim para as meninas: "Eu não sou saudosista não, mas eu não posso me esquecer do que esta escola era e do que ela é hoje. Porque só assim eu valorizo essas pequenas coisas" [...] [...] Já chegou o tempo de o estudante trazer um fósforo e a vasilhinha de desodorante cheio de álcool para jogar no professor. Todos os dias a gente tinha brigas entre eles. $\mathrm{Eu}$, enquanto professora, peguei uma estudante esfaqueada aqui na porta, teve uma briga fora da escola, chegaram no portão...

[...] Quando a gente começa a se envolver mais com as questões raciais e a ouvir o aluno a gente começa a entender "porque meu menino é tão arredio, porque meu estudante é dessa forma".

Em seu depoimento, Dudu relaciona o fato da escola ter se tornado quilombola à desconstrução da visão negativa sobre ela, sobretudo no interior da própria comunidade:

Minha família mesmo já expõe de uma outra forma, porque antes a escola era vista de uma forma marginalizada, devido até porque vivíamos na marginal, né? Ainda vivemos na marginal aqui na comunidade, mas antes a visão da comunidade de fora, era uma coisa ruim, muitos tinham essa visão ruim da escola, agora começa a ser descontruída. Depois que ela foi reconhecida quilombola, começou a ter uma atenção maior do Estado, uma atenção maior, uma atenção cultural de preservar as raízes e tudo isso. Então, começou a ser diferente, isso começa a ser desconstruído. Eu mesmo tinha um certo preconceito com relação aqui. Não minto, tinha um certo preconceito com relação à escola. E a partir do momento que eu vim estudar aqui... porque o pouco que eu lembrava daqui era muito antigo, entendeu?... Não era dessa forma. A partir 
do momento que eu vim estudar aqui, eu comecei a desconstruir isso, eu comecei a ter uma visão diferente com relação à escola.

Manuela, em sua narrativa, expõe o quanto foi trabalhoso esse processo de aceitação do status quilombola pelos membros da comunidade:

Os alunos, e as mães vinham para cá e diziam. Em um primeiro momento, quando a escola se auto reconheceu, quando começou a valorizar o negro, nós perdemos vários estudantes. Então, no processo de autorreconhecimento e de efetivação das leis educacionais, a gente foi modificando também a postura da escola. A escola não é mais um local de pessoas que não querem nada, porque a escola aqui era vista assim, quem não quer estudar vem para cá. "Então, vamos mudar isso aqui. Não, aqui é lugar de quem quer estudar, todo mundo que está aqui é competente, todo mundo que está aqui é inteligente, agora precisa seguir normas". [...] Então, a gente começou mudar, querendo assim, a escola vai ser desse jeito, tem horário de chegada, tem horário de saída. E as pessoas da comunidade foram associando isso também ao reconhecimento como escola quilombola. Que de um lado foi positivo, mas não foi por ela ser quilombola, é que a gente passou a usar a lei educacional, nós reconhecemos e usamos a lei. E agora é o contrário, agora a gente tem fila de espera.

Nota-se que ela relaciona a mudança na percepção da escola à postura da gestão no cumprimento de leis educacionais, o que, por conseguinte, foi determinante para que o status quilombola pudesse ser percebido pelos moradores como positivo. Manuela argumenta que as mudanças ocorridas na escola foram tomadas a partir das DCNS para EEQ:

Pesquisadora: Com relação às Diretrizes Curriculares Nacionais para Educação Escolar Quilombola... algumas modificações que vocês fizeram foi seguindo essas diretrizes?

Manuela: Isso, foi seguindo essas diretrizes.

Pesquisadora: E as diretrizes estaduais? Do Estado da Bahia ainda não foi implementada, né?

Manuela: Não foi ainda implementada. A gente ainda trabalha com... que é a estadual [pegou a lei das diretrizes estaduais que estava na prateleira a seu alcance]. Ela é dentro da nacional. Ela já foi formulada e já está em ação. Tanto é que eu tenho que trabalhar isso com os professores.

Pesquisadora: Você consegue uma para mim?

Manuela: Consigo, eu vou pedir uma para você. Eu tinha umas quinze, mas foi chegando gente e pedindo.

Pesquisadora: Ela foi feita em 2013, né?

Manuela: 2013. Quando completou dez anos da lei 10.639 as diretrizes aqui surgiram. Aí tem os princípios da educação, da avaliação. A parte administrativa está toda aqui, da escola, mas a pedagógica ainda...

Pesquisadora: Se refere à nacional também?

Manuela: Se refere à nacional. Ela está dentro da nacional, você cumprindo a nacional, você cumpre a estadual. A estadual agora, nessa nova mudança, o que vai ter é a história da cultura baiana, da educação baiana.

Pesquisadora: Que é o que vocês estavam querendo fazer naquelas disciplinas?

Manuela: Isso. Mas não deu certo, né? Estamos tentando, mas não deu certo ainda. Então, eu estou sempre olhando, olha aí oh: "Garantir a educação escolar na forma da lei” [leu um trecho das diretrizes estaduais para educação quilombola]. Então, tudo que vai da parte administrativa eu consigo implementar, mas o que vai para a parte pedagógica... 
A Bahia foi a primeiro a criar a Diretrizes Curriculares para a Educação Escolar Quilombola em nível estadual; como disse Manuela, a maior parte do conteúdo se baseia nas Diretrizes Nacionais, exceto no acréscimo de alguns conteúdos considerando as especificidades do contexto do referido estado: Art. 30 " [...] garantir ao educando o direito a conhecer o conceito, a história dos quilombos no Brasil e na Bahia, o protagonismo do movimento quilombola e do movimento negro, assim como seu histórico de lutas" (BRASIL, 2013b). Em seu Art. 45, que versa sobre a necessidade de criação de espaços de discussão, pesquisa e estudos para a formação continuada dos profissionais de educação para essa modalidade de ensino, recomenda-se o estudo e a pesquisa sobre a história dos quilombos na Bahia.

Consta ainda, nas referidas Diretrizes (nacionais e estaduais), a importância da criação de um calendário escolar específico, considerando as datas comemorativas mais significativas para a população negra e para cada comunidade quilombola: “O calendário da Educação Escolar Quilombola deverá adequar-se às peculiaridades locais, inclusive climáticas, econômicas e socioculturais, a critério do respectivo sistema de ensino e do projeto políticopedagógico da escola [...]" (BRASIL, 2012b, p. 07), a partir da consulta das comunidades e lideranças quilombolas. Manuela esclarece que a escola não conta com um calendário específico:

\footnotetext{
Pesquisadora: Escola não tem calendário específico, né?

Manuela: Não e nem pode, já enviamos e foi negado. Tem uma lei que ampara a escola de ter um calendário específico, só que essa lei nunca é levada em consideração. A gente manda para lá e todo ano é rejeitada. Tanto que tem dois anos que eu não mando mais.

Pesquisadora: Você acha que há alguma imposição por parte da secretaria de educação?

Manuela: Não, é porque a escola é quilombola. É porque eles não querem ter o trabalho de acompanhar mais de um calendário.
}

As DCNs atribuem a responsabilidade às instâncias federais, estaduais e municipais pela garantia e oferta da EEQ, orientam a ação conjunta e colaborativa dessas instâncias. Em seu depoimento, Manuela revela que não encontra muito respaldo na esfera municipal:

Pesquisadora: Há interesse por parte da prefeitura com relação à educação quilombola?

Manuela: Não vejo assim um interesse não. Inclusive as reuniões da prefeitura eu deixei de frequentar porque eu estava me sentindo discriminada, porque quando eu ia falar da educação quilombola, dos direitos quilombolas, muita gente torcia o nariz. Eu falei: "Olha eu vou ficar na minha", porque aqui é estadual, né? Na rede estadual eu percebo a valorização, a coordenação da Secretaria de Diversidade.

Pesquisadora: O município tem Secretária da Diversidade?

Manuela: Tem[...]

Pesquisadora: Você sabe quais são os benefícios que a comunidade tem ao se tornar quilombola?

Manuela: Olha, o benefício que ele já tem adquirido é o Bolsa Família, as cotas quilombolas nas universidades estaduais, o desconto no aviso de água e luz, agora 
outros... Ela tem direito a um posto de saúde quilombola, mas o posto de saúde ainda não se auto reconheceu, ainda não recebeu as verbas, ela tem direito a uma creche quilombola.

Pesquisadora: Tem um posto aqui?

Manuela: Tem um posto aqui. Tem direito a uma creche que trabalhe com a cultura afro-brasileira, uma creche quilombola. Nós temos duas creches que ainda não têm esse trabalho da nossa história. [...] A prefeitura clicou no botão quilombola e não avisou a eles. Eu levei três anos explicando aos diretores como uma escola se autorreconhecia, que era só clicar em um botão e, quando foi o ano passado, descobri que eles ainda não tinham feito isso. Aí, eu sai atrás da comissão quilombola, eu falei: "Olha estou tão decepcionada gente que eu vou sair da comissão.” Aí, eu sai.

Pesquisadora: A prefeitura não fez um trabalho de conscientização?

Manuela: Não. Ela fez o trabalho de captação de verba, entendeu? E isso não foi repassado para a comunidade. Então, acordar as pessoas para isso teria que ser a associação, né?

Pesquisadora: ...do bairro, para os próprios moradores reivindicarem, né?

Manuela: E é uma reinvindicação morosa de ser atendida, e eles se cansam. Eles brigam por pequenas coisas e param. Eu fiquei muito tempo dando uma força. Eu participava de todas as reuniões da associação da comunidade.

A fala de Manuela expõe dois grandes obstáculos à efetivação das EEQ: o descaso do poder público que, muitas vezes, está interessado apenas na captação de recursos que deveriam ser revertidos em benefícios para a comunidade quilombola; e a discriminação institucional, evidenciada na resistência ao debate e discussão dos direitos e das demandas educacionais particulares da comunidade.

O depoimento de Manuela evidencia o quanto a EEQ e o acesso a determinados direitos encontra-se, muitas vezes, à mercê da atitude de atores de fora da comunidade. Ao mesmo tempo, ela salienta a importância da participação da comunidade na reivindicação de seus direitos, e o papel central da Associação de Bairro na conscientização da comunidade. Além disso, ela assinala o esforço que as instituições que atuam nas políticas públicas em prol das comunidades quilombolas deveriam empreender para que essa conscientização ocorra, por exemplo, junto aos gestores de creches municipais no sentido de referenciar a importância de que sejam classificadas como "situadas em área de quilombo".

Quanto ao contexto escolar em que atua Manuela, para a implementação das DCNs para a EEQ juntamente com as DCNs para ERER, pensou-se, a princípio, na possibilidade de construção de disciplinas específicas para inserção, no currículo escolar, de conteúdos que contemplassem a história de quilombos no Brasil e na Bahia, e a História e cultura afrobrasileira e africana.

Pesquisadora: Como que foi a implementação das disciplinas? Vocês têm duas disciplinas aqui específicas?

Manuela: Não, a princípio nós pensamos em fazer isso em 2008, nós montamos o PPP da escola junto com o programa Mais Educação. Você conhece o Mais Educação? Pesquisadora: Sim.

Manuela: O Mais Educação veio a trabalhar com a autoestima, a pintura para a mulher negra, o cabelo negro, também foi bem direcionado à mulher, já que dos nossos 
estudantes a maioria é mulher. E o cabelo era um detalhe que as mulheres mais rejeitavam para elevação da sua autoestima, a cor da pele nem tanto, mas o cabelo... Aí, nós começamos a trabalhar com o Mais Educação em turno oposto às oficinas de maquiagem, de cabelo, de turbante, de trança, desfile da beleza negra e aí começamos a trabalhar com autoestima da mulher negra e colocamos a história da cultura afrobrasileira. Só que nós percebemos que ficou preso a uma disciplina e que, por ser uma escola estadual, você não tem como escolher quem vai ficar com aquela disciplina, você escolhe aquele que tem aquele perfil, mas esse perfil você também não se identifica como afro-brasileira. Você não se identifica com a história, você se identifica com a história europeia, aí você acaba passando para o estudante a sua definição.

Pesquisadora: Então, não foi encontrado na escola alguém que tivesse...

Manuela: Não, não encontramos ninguém na escola com esse perfil. Ao contrário, na época tínhamos uma professora aqui com traços negros, do que é considerado negro no Brasil, né? ...Que é a pele e o cabelo, e ela sempre que vinha conversar comigo falava: "Olha eu sou a única preta na família, na minha família tem loiros dos olhos azuis, do cabelo liso, é que o meu cabelo foi um problema que eu tive na infância que caiu o cabelo e nasceu outro ruim". Ainda chamou de cabelo ruim. E ninguém se identificava como negro, e o racismo muito presente. Apesar da professora dizer que nós não podemos ser racistas, na concepção dela de racismo, você é racista você é a classe superior e a outra é inferior. Mas aqui o racismo você nem se identifica com a classe superior, mas você é racista, você não aceita os traços de negros. Então, todos os funcionários eram racistas e todos os professores também eram racistas, sem essa consciência. Como é o racismo no Brasil, né? ... Que é um racismo velado.

Manuela argumenta que as disciplinas não foram implementadas por não haver na escola alguém com um "perfil”" apropriado para lecioná-las. O “perfil” pensado por ela parece associado a um(a) professor(a) negro(a), talvez por acreditar que, sendo negro, este se identificaria com a cultura africana e afro-brasileira, e, por conseguinte, se envolveria com a proposta curricular.

Como sabemos, a cor da pele não é garantia de posição identitária negra política ou cultural, o que ficou claro no caso da professora, cuja fala revela a autonegação identitária. Como vimos o racismo enquanto "crime perfeito" se consolida quando a pessoa negra busca se branquear, é uma rejeição do corpo que se traduz em negação de si mesma (VANNUCHI, 2017, p. 67). A identidade negra é uma construção que envolve, entre outras coisas, consciência das artimanhas ideológicas do racismo. Mas é um processo lento, algumas vezes difícil de ser desconstruído.

Com relação à criação de disciplinas específicas para o trato das relações étnico-raciais, Manuela lembra que a Lei 10.639/2003 determina que os conteúdos referentes à cultura e história africana e afro-brasileira perpassem todo o currículo escolar. Outros aspectos que concernem à forma de efetivação dessa lei aparecem em seus desdobramentos, como na Lei 9.394/1996, cujo texto destaca o lugar das áreas de Educação Artística e de Literatura e História Brasileiras na abordagem do referido conteúdo, e nas Diretrizes Curriculares Nacionais para a 
Educação das Relações Étnico-Raciais e para o Ensino de História e Cultura Afro-Brasileira e Africana.

A interdisciplinaridade também é enfatizada nas Diretrizes Curriculares Nacionais para a Educação Escolar Quilombola, ao orientar que o currículo quilombola deve se pautar em ações e práticas pedagógicas que visem "[...] a interdisciplinaridade e contextualização na articulação entre os diferentes campos do conhecimento, por meio do diálogo entre as disciplinas diversas e do estudo e pesquisa de temas da realidade dos estudantes e de suas comunidades" (BRASIL, 2012b, p. 30)

Manuela menciona ainda que a maioria dos professores tem dificuldades em trabalhar com conteúdo relativos à temática das relações étnico-raciais devido à educação eurocêntrica que receberam:

\begin{abstract}
Pesquisadora: Este "currículo quilombola" chega no conteúdo, com os professores? Manuela: Cinquenta por cento chega, já temos professores preocupados em colocar. Mas nós não temos uma disciplina porque... eu nem terminei de concluir. Tivemos essa disciplina e não deu certo e a Lei 10639.03 diz que tem que percorrer todas as disciplinas. Então, língua portuguesa tem que mostrar o legado, matemática... Tentamos a etnomatemática aqui, por dois anos, e não deu certo. A professora Marta era uma doutora lá da UESB, ela veio aqui, teve o professor Júlio que tentou acompanhar, só que o professor Júlio é protestante então ele tem... Aí, desistiu, não foi adiante. Aí, convencemos a professora Nina para ficar com a etnomatemática, também desistiu. É que o grande problema de você efetivar a Lei 10.639, isso eu vim perceber esse ano, porque até então eu não conseguia... uma magoa, um ressentimento, um sentimento de fracasso: "Porque meus professores não efetivam a Lei 10.639 ? Uma coisa que está no nosso PPP, que é discutida, você entra na escola você vê a história negra olhando para a escola, para o cardápio da escola". Aí, depois eu fui perceber a dificuldade do nosso professor. É que ele tem que voltar a estudar, ele apreendeu a cultura europeia, ele aprendeu a discriminar toda a cultura africana de forma dissimulada. Então, hoje ele tem que parar para estudar. E estudar... enquanto professores usamos esse discurso "Você tem que estudar", mas estudar não é fácil, pesquisar é muito difícil, se debruçar sobre um assunto, falar: "Bem como eu vou trabalhar agora aqui com literatura para que esses meninos enxerguem Machado de Assis negro? Como é que eu vou fazer isso? Porque anos ele foi branco, eu conheci ele como branco". Aí, você tem que refazer todo o seu estudo porque na universidade você aprendeu ele branco. Isso dá muito trabalho e na sociedade onde você tem que ter muito dinheiro, seu tempo tem que valer algo remunerado, aí você vai passando qualquer coisa, o que você aprendeu você vai repassando. Então, esses pequenos cursos, as reuniões vão começando a despertar em você, mas este despertar é tão lento.
\end{abstract}

Manuela nesse comentário, lembra que o professor, como todos os sujeitos sociais, foi formado por esse sistema educacional, pensado em moldes eurocêntricos, que desconsidera a pluralidade e múltiplas diferenças presentes na sociedade brasileira, onde as representações de sujeitos históricos, como as populações negra e indígena, sempre se deu de maneira folclorizada e estereotipada, na maioria das vezes relacionadas ao passado, como se estivessem mortos, relegando-os à invisibilidade. Entregando, mesmo existindo no estado da Bahia uma universidade onde essas questões são colocadas, ainda são precárias as possibilidades de passar 
essas contribuições para o corpo docente das escolas públicas. E há uma visão ainda idealizada do que seria um currículo capaz de se contrapor a essa formação eurocêntrica. $O$ elogio da mestiçagem, que vigorou no Brasil a partir da década de 1930, ainda é poderoso na cultura escolar. Sob a égide do discurso "todos somos mestiços", procurou-se encobrir as contribuições dessas populações, concomitantemente ao encobrimento da violência racial. Por outro lado, fezse prevalecer o branco em todas as dimensões do currículo escolar. E, assim, através da exaltação de um sangue mestiço que engoliu o negro e o indígena, adoecemos.

No transcorrer desse processo de elaboração de um projeto excludente de educação, a escola se torna meio transmissor de concepções arraigadas no imaginário coletivo e elaboradas pelo grupo dominante colocando-se, dessa forma, a serviço para perpetuação de seus privilégios. O mito da democracia racial circula no meio escolar sendo, portanto, parte do currículo, produzindo a compreensão de que falar de cultura africana e afro-brasileira é sinônimo de racismo e que, assim, sobre elas se deve silenciar. Nesse sentido, concordamos com Manuela, quando diz que o professor apreendeu a discriminar as culturas africana e afrobrasileira de forma dissimulada.

A dissimulação é característica primordial do nosso racismo, aliada à sutileza, cordialidade e ambiguidade e a outras tantas peculiaridades, pois segundo Munanga (2017, p. 41), ele é “[...] difuso, sutil, evasivo, camuflado, silenciado em suas expressões e manifestações, porém eficiente em seus objetivos". A esse respeito, Manuela refere o racismo presente nas relações escolares como um dos grandes obstáculos à efetivação de uma educação para as relações étnico-raciais. Atuando silenciosamente no meio social, ele alija as consciências (MUNANGA, 2017) e reforça o currículo racista oculto, implícito em gestos, olhares, brincadeiras, agindo de forma a extirpar física e simbolicamente o segmento negro desse espaço. Assim, "O não dito é uma construção que tem como objetivo direcionar as subjetividades não hegemônicas à não aceitação social, ou seja, reforça os padrões que instituem a discriminação[...]" (SILVÉRIO, et al. 2010, p. 119).

Muitos são os desafios a serem enfrentados para a implementação das DCNs para ERER e referentes à EEQ: reconstrução curricular; reelaboração da formação acadêmica de professores; formação continuada de professores; elaboração de materiais didáticos, etc.

Apesar dos avanços expressivos promovidos na avaliação dos livros didáticos, para evitar preconceitos e outros equívocos; nos PCN, que têm um capítulo dedicado ao pluralismo cultural enfatizando a necessidade da formação dos professores no tema (BRASIL, 1997), urge encontrar e definir medidas para os professores intervirem na questão racial. Esses parâmetros representam um avanço considerável rumo ao tratamento eficaz da questão, mas os dispositivos legais existentes mantêm-se prudentemente no campo das formulações abstratas, seja na Constituição, seja na LDB: são reticentes as propostas de combate ao racismo e pouco delineadas as 
medidas concretas de abordagem. Nada adianta ter livro didático e currículo apropriados se o professor for preconceituoso, racista, e não souber lidar adequadamente com a questão. (VALENTE, 2011, p. 26).

As observações de Manuela revelam que um dos principais entraves, depois de doze anos de vigência da Lei $n^{\circ} 10.639 / 2003$, subjaz no presente: educar o professor para que possa atuar na educação das relações étnico-raciais. Essa lei determina que a inclusão de conteúdo, práticas e currículos seja pensada em conjunto pelas instituições de ensino, esferas públicas e comunidade escolar e enfatiza que a responsabilidade de erradicar o racismo de nossas relações é de toda a sociedade brasileira. Aponta que a formação dos professores é reponsabilidade dos Entes Federados (União, Estados, Distrito Federal e municípios) e demanda ações que devem ser acompanhadas por Secretarias de Educação e Conselhos Municipais. Em relação à formação dos professores, alguns pontos expostos nas Diretrizes Curriculares Nacionais para Educação das relações étnico-raciais devem ser ressaltados:

Introdução, nos cursos de formação de professores e de outros profissionais da educação: de análises das relações sociais e raciais no Brasil; de conceitos e de suas bases teóricas, tais como racismo, discriminações, intolerância, preconceito, estereótipo, raça, etnia, cultura, classe social, diversidade, diferença, multiculturalismo; de práticas pedagógicas, de materiais e de textos didáticos, na perspectiva da reeducação das relações étnico-raciais e do ensino e aprendizagem da História e Cultura dos Afro-brasileiros e dos Africanos. Inclusão de discussão da questão racial como parte integrante da matriz curricular, tanto dos cursos de licenciatura para Educação Infantil, os anos iniciais e finais da Educação Fundamental, Educação Média, Educação de Jovens e Adultos, como de processos de formação continuada de professores, inclusive de docentes no Ensino Superior. (BRASIL, 2004b, p. 24)

O relato de Manuela nos leva a questionar: Como sensibilizar o professor para que ele desperte o interesse em obter conhecimentos com relação às culturas africana e afro-brasileira, em ressignificar sua prática educativa? A problemática do racismo está posta cotidianamente a ele nas manifestações de discriminação, mas como incentivá-lo a enfrentá-las?

Pesquisadora: Você acha que os professores buscam cursos para melhorar esse conhecimento?

Manuela: Não parte deles a procura, porque eu estou há dez anos aqui, o ODERE oferece curso de extensão, curso de especialização e curso de mestrado em educação quilombola, cultura afro-brasileira, didática da cultura afro-brasileira. Eu só tenho aqui duas professoras que fizeram o curso, em dez anos. Ninguém nunca tem tempo de fazer o curso. O curso está sendo oferecido na escola no dia de aula, é um dia de sexta-feira e um dia de sábado, que é contado como sábado letivo, e nós não tivemos cem por cento dos professores.

Pesquisadora: Quantos por cento você acha que aderiu?

Manuela: Acho que foi cinco por cento ou menos, eu não fiz a conta matemática, mas nós temos cinco professores, fora o administrativo.

Pesquisadora: Fazendo o curso?

Manuela: Fazendo o curso. A professora Nina, professor Reinaldo, Carla, Marli, Carolina... É são esses aqui. Aí, entra... "Eu estou fazendo" "Ah você vai fazer?" "Vou fazer sim". 
Pesquisadora: Você atribui isso mais à questão do tempo e...

Manuela: ...do comodismo e a religião. E na primeira aula do curso vi muito torcer de bico, porque não tem como você falar da cultura africana sem falar do Candomblé.

Pesquisadora: Em relação a esses professores e esses funcionários que aqui estavam? Manuela: É. Então, é a questão do tempo, do querer... porque, assim, é um querer que eu também não entendo. Porque no início do ano letivo eu falo assim: "Gente quem não quer vamos fazer assim...." Uma vez eu fui dura, uma não, várias vezes eu sou. "Vamos sair da escola. Quem não tem esse pertencimento, quem não consegue reconhecer que o mundo carece da igualdade, que a história negra e a história europeia sejam trabalhas com equidades, sai da escola. Vamos sair da escola". Não sai da escola. Quando vem para cá um prestador de serviço temporário (Professor de apoio) senta aí onde você está e eu informo: "Olha é uma escola quilombola, você vai dar ênfase na cultura afro-brasileira, você vai ter que ter um olhar negro sobre sua disciplina. Então, vai estudar redação, você vai estudar com olhar negro; você vai procurar como é inserido o homem no mercado de trabalho, o homem negro e a mulher negra; como aconteceu a conquista do povo negro para ter hoje as cotas, o que são as cotas. Então, você vai trabalhar isso em redação, você vai trabalhar em língua portuguesa". Aí, a pessoa aqui concorda, quando vai para sala de aula é outra coisa. Manuela: Aí eu: “Ai meu Deus do céu!". Aí, vamos recomeçar tudo de novo. Tem aquela "Cor da cultura", o projeto. Aqui era para a escola ser nota dez na "Cor da cultura", mas não consegue. Eu tenho um professor aqui que não fala com duas funcionárias porque são negras. A professora Isabel, de inglês. Ela se define branca e tem os traços brancos.

Manuela fala com tristeza sobre a falta de adesão de professores ao curso ofertado pelo grupo ODERE, atribuindo o desinteresse ao comodismo e ao fator religioso. As Diretrizes Curriculares Nacionais para a Educação das Relações Étnico-Raciais e para o Ensino de História e cultura Afro-brasileira e Africana ressaltam: "A luta pela superação do racismo e da discriminação racial é, pois, tarefa de todo educador, independente do seu pertencimento étnicoracial, crença religiosa ou posição política.” (BRASIL, 2004b, p. 16).

O preconceito pode ser um grande entrave no despertar de interesse pela temática das relações étnico-raciais. Daí a necessidade de trabalhar na base e não apenas na ponta do iceberg - na formação inicial, nos cursos de licenciatura e graduação. Se o professor no processo de socialização, sobretudo na escola, recebeu uma educação que o fez internalizar estereótipos sobre a cultura e história de grupos socialmente estigmatizados, o mesmo não pode ocorrer durante sua formação inicial. Dessa forma, oportunizar aos futuros educadores conhecimento e reconhecimento de valores culturais, históricos e políticos desses grupos formadores da sociedade brasileira é crucial para que ele possa ter oportunidade de desconstruir mitos e estereótipos, recuperar omissões históricas, ressignificar e rever representações que imobilizam e inviabilizam um posicionamento crítico e político sob seu fazer docente.

Para Mülle e Coelho (2013), há uma associação direta entre os desafios de implementação da Lei 10. 639.03 e a formação dos professores. A autora ressalta que a introdução de abordagens relativas à desconstrução de falsificações e estereótipos sobre a população negra "[..] implicam um grande esforço pessoal do docente, mas também de toda 
unidade escolar e na implementação de políticas públicas que venham a garantir a legitimidade desses novos conhecimentos e práticas, e a formação continuada dos educadores e seus formadores". (MÜLLE; COELHO, 2013, p. 50). As autoras argumentam sobre a necessidade de cursos de formação para professores do Ensino Superior, especialmente para aqueles que lecionam nos cursos de licenciatura e apontam algumas ações necessárias para a efetivação da Lei 10.639/2003, dentre elas: maior oferta de cursos de especialização, mestrado e doutorado com ênfase na temática para os professores da rede pública de ensino; e ampliação de editais nas agências de financiamento para investigação.

Em 2012, com o objetivo de discutir os desafios e as perspectivas referentes à Lei 10.639/2003, transcorridos quase dez anos após sua criação, foi realizado um Seminário Virtual Nacional ${ }^{106}$. Entre os temas propostos para discussão estava "A educação para as relações étnico-raciais e os desafios para a formação inicial e continuada dos professores(as)". A esse respeito, as intervenções dos participantes apontaram algumas considerações como: o fato de que a inclusão da temática no currículo de cursos de formação inicial estava ocorrendo, porém de maneira lenta e insuficiente; pouca oferta de cursos sobre a temática pelo poder municipal, ficando o trabalho nas escolas restrito a ações isoladas de alguns professores ou a datas comemorativas; e forma irregular em que os cursos de formação continuada são oferecidos.

Finalmente, concluiu-se que a inclusão da lei vinha contribuindo para a descolonização do currículo, ainda que fragilmente. A maioria apontou que as mudanças vinham ocorrendo de maneira muito lenta e associaram esta lentidão à ausência na formação inicial e continuada de professores e gestores das matrizes de origem africanas e afro-brasileiras (DOSSIÊ, 2014, p. 25-41).

Um outro tema "Currículo e educação das relações étnico-raciais" se refere às tensões e inter-relações entre currículo e a Educação das Relações Étnico-Raciais. Da análise desse debate foram apontados alguns elementos deflagradores das tensões que dificultam a efetivação de uma Educação para as relações étnico-raciais: existência de um currículo eurocêntrico; ausência de informações sobre a referida lei nas escolas e desconhecimento dela por parte de muitos professores; desconhecimento da temática das relações étnico-raciais; falta de interesse público na formação continuada dos docentes; ausência da regularização da lei nos currículos, livros didáticos e no projeto político-pedagógico das escolas; falta de comprometimento de

${ }^{106}$ O Seminário Virtual Nacional ocorreu em 2012, por meio do portal da ABPN, teve como objetivo discutir desafios e perspectivas sobre a implementação da Lei no 10.639/2003. 
muitos gestores, coordenadores e professores; e o racismo e o embranquecimento presente nas relações escolares (DOSSIÊ, 2014, p. 42-57).

O racismo e o embranquecimento também são enfatizados por Manuela como males que dificultam a realização de cursos de formação continuada e de projetos na escola que abordem as relações étnico-raciais e dos quilombolas. Para além dos entraves relativos à implementação do currículo quilombola, ela fala entusiasmada de algumas conquistas que atribui às modificações ao contexto escolar, como a adesão de alguns professores ao curso e mudanças significativas que percebe em funcionários, educadores e alunos quanto ao autoreconhecimento e à autoidentificação como negro(a).

Pesquisadora: Você se define...?

Manuela: Negra. Eu acho que aqui na escola hoje já tem uns sessenta por cento que se autorreconhecem.

Pesquisadora: Você acha que isso veio a partir do contexto da escola?

Manuela: Tenho certeza, absoluta. Porque se você conversar com a professora Joana de História, ela se percebia branca, no discurso dela ela nem percebia que ela se percebia branca e depois, com o passar dos anos, ela já conta relatos de discriminação que ela sofreu que ela não contava antes, ela não relatava. Então, ela já começa a relatar, ela já consegue perceber as filhas, o discurso dela hoje é diferente. Porque se você é discriminada você está se autorreconhecendo, né? Então, você não pode relatar nenhum fato de discriminação. E hoje ela já consegue fazer isso. A professora Nina... eu acredito que ela se declare branca ainda, porque ela, não só ela, nós ainda... negro é a pele e o cabelo, né? Ela tem a pele branca e o cabelo crespo. Aí, a cor da pele é que ela declara. Pouca gente vê o cabelo dela solto. Agora uma coisa interessantíssima... é uma professora prestadora de serviço nossa, são os professores que ficam temporariamente na escola, né? Você não tem um efetivo....

Pesquisadora: Ah, aqui chama prestadora de serviço?

Manuela: É, aqui chama PST - prestadora de serviço temporário. Uma veio para cá e trabalhou conosco por dois anos, uma professora de química, ela está até fazendo mestrado agora. E ela não se reconhecia como negra, ela foi criada... eu conheço porque ela também é da minha relação pessoal, eu já conhecia a história dela e veio para cá, de tanto que ela ficou vendo o trabalho... E a semana passada eu encontrei com ela, ela saiu daqui porque a professora retornou... Ela assumiu os cabelos afro dela, ela esticava, esticava (risos). Assumiu a identidade dela, eu disse: "Pri, menina, eu não acredito no que eu estou vendo!". E ela assumiu. A professora Jane. Você conheceu? .... de Artes?

Pesquisadora: Não. Ontem eu conheci, só os meninos, os professores.

Manuela: O professor Reinaldo, Júlio, Mauro.

Pesquisadora: Eu conheci dois professores negros, mas foi muito rápido e estavam entrando nas salas, não deu para me apresentar e saber os nomes.

Manuela: Foi um negro?

Pesquisadora: Tinha apenas um branco de globo na mão. Seria de geografia?

Manuela: Foi de Geografia, Mauro. Você conheceu então, o de matemática, que é Júlio, protestante, e Reinaldo que é o católico. São os negros que nós temos aqui. O Reinaldo já se declara como negro. Já Júlio como tem o cabelo mais sedoso, ele... ele é negro, pele negra, mas tem o cabelo sedoso então, fica indeciso...

Pesquisadora: Talvez se declare então como pardo. Mas pardo também faz parte da população negra, né?

Manuela: Ah, ele também está fazendo o curso, Júlio, e eu achei ótimo (fala entusiasmada). Ele está no curso e agora eu lembrei porque ele fez algumas colocações. Como você falou em pardo, eu lembrei, porque no curso a gente discutiu sobre isso e ele fez algumas colocações que eu pensei: "Nossa! Não sabia que o discurso de Júlio ainda era tão carregado". Porque no discurso da gente é que a gente percebe, né? 
Pesquisadora: É.

Manuela: E ainda hoje eu percebo nos meus discursos o racismo. Menina, às vezes eu me pego assim: "Meu Deus eu estou falando isso".

Pesquisadora: É algo que está internalizado e a gente tem que ressignificar.

Manuela: Isso, é coisa simples. Esses dias eu vi uma negra saindo de uma casa bem estruturada, uma casa de rico e de imediato a sua mente já pensa na empregada doméstica. Aí, depois que eu penso, eu: "Meu Deus do céu que é isso Manuela!?". Aí, se eu penso assim imagina ainda quem não reconhece, como é que está pensando? Com a certeza. Porque eu penso e depois eu vou refazer, reestruturar "Não, não é dessa forma".

Pesquisadora: É um olhar de naturalização.

Manuela: É um olhar de naturalização. Então, vê: "É normal, é aquilo mesmo". Não questiona. Então, a escola tem ajudado bastante os nossos estudantes na elevação da autoestima. O que a gente tem feito é fantástico. É assim... vamos entrar na história. Porque você conversa com nossos meninos, hoje eles são empoderados, né? Eles conseguem pensar em estar trabalhando em um banco, em fazer uma faculdade, eles conseguem perceber que o ensino médio é muito pouco, precisa ir além. Então, a gente tem conseguido esta autoestima forte, quarenta por cento dos estudantes já tem ela bem forte e os outros $60 \%$ estão desenvolvendo essa autoestima. E é um número elevadíssimo, para uma escola que há nove anos atrás estava tudo naturalizado.

Pesquisadora: Você atribui essa mudança ao que?

Manuela: À mudança do discurso da direção.

Pesquisadora: E ao trabalho do professor em sala?

Manuela: Ainda não, ainda não.

Pesquisadora: Seria mais do contexto mesmo?

Manuela: Da modificação da escola, da merenda da escola, da mudança do nome. Eles perguntam constantemente o motivo da mudança do nome. Aí eu explico...tanto que vai fazer uma entrevista aqui: "É para falar sobre negro professora?" (risos)

Pesquisadora: E você acha que os alunos questionam de alguma forma os professores? Manuela: Questionam, não reivindicam muito a mudança, mas eles questionam porque tem professores que na reunião dizem assim que, às vezes, tem que parar $\mathrm{e}$ pensar, que realmente os estudantes estão percebendo. Agora, não é uma coisa muito presente porque senão eu perceberia fora da sala de aula, só nas conversas de corredores e no AC, quando eu estou acompanhando. Eu só percebo em reuniões, quando eu trato da temática.

Pesquisadora: Essa questão dos alunos?

Manuela: Dos alunos, como é que eles estão. Agora a gente já percebe visivelmente a autoestima deles. E também essa proposta da escola de trazer para seu quadro de funcionários pessoas da comunidade e estudantes. Então, isso também... porque aí eles vão ouvindo mais, porque esse sentimento de valorização da cultura afrobrasileira está cem por cento no administrativo, nos funcionários e na equipe gestora, e no corpo docente ele está nascendo. E tudo que está nascendo é muito frágil, precisa de cuidado, e esse cuidado eu tenho aqui, com o discurso, o que falar, como mostrar as coisas, como mostrar para eles que a solução está aqui na escola. Mas lá fora esse discurso meu é desconstruído por todas as mídias e por todas a pessoas com quem eles convivem, em sua grande maioria. Então, tudo que eu construo aqui, em quatro horas e meia, e, com alguns, nove horas, porque tem professores de quarenta horas, é desconstruído lá fora. Então, nesse construir-desconstruir, fica pouco. E em dez anos aqui... a lei tem dez anos e a escola oito anos, é muito curto para quem nunca pensou nisso. E outra coisa, não é você quem está querendo pensar, eu é que estou pedindo a você para pensar. E isso é bem diferente. Eu tiro por mim, porque eu quis pensar nesse assunto... $\mathrm{Na}$ época eu nem sabia que eu queria pensar, o ODERE abriu a especialização e eu decidi fazer.

Pesquisadora: Qual especialização?

Manuela: Antropologia com ênfase em cultura afro-brasileira. E eu quis fazer. Então, lá é que eu fui começar a perceber e aí eu quis...

Pesquisadora: Mas você já se identificava?

Manuela: Não me identificava. Eu me identificava como branca. Eu vivi em uma família que o negro não era gente. Minha mãe ainda hoje é muito racista, eu trabalho muito isso. Então, eu venho de uma família racista... 
Pesquisadora: Qual a composição da sua família?

Manuela: Na minha família tem negro... na minha família materna não tem negro, como é chamado aqui no Brasil, acho que nem na terceira geração, né? Que nos EUA é até a terceira geração. Já na minha família paterna, meu pai tem negro na família e tem índio, mas na minha família materna não tenho. E meu pai ele é... seria o moreno, né? ...o caboclo, meu pai é caboclo.

Pesquisadora: É a pele negra bem escura e o cabelo liso. Meu pai também tem essa dificuldade em se autorreconhecer, ele fala que ele é queimado do sol, tem a mistura indígena e de negro, que é identificado como caboclo, principalmente aqui na Bahia. Manuela: Então, o cabelo saiu liso.

Pesquisadora: E seu pai tem os traços negros?

Manuela: Ele tem o nariz mais achatado. Minha mãe ficou um ano sem falar comigo no período em que eu estava fazendo a especialização, porque ela disse que eu estava ficando doente, que eu só falava de negro, que eu queria ser negra a pulso, que eu não era. E quando eu quis me autorreconhecer ela achou um absurdo. Mas acho que já está bem melhor também. Então, por isso que é difícil com o professor, porque não está saindo dele, nós é que estamos pedindo para ele, né? A escola está pedindo. Agora se ele continua na escola, é porque ele vê que existe algo que ele pode fazer, ele só não tem essa consciência, né? Tem isso também.

Pesquisadora: Essa sua autoidentificação você atribui mais ao que?

Manuela: Eu vejo pela questão dos meus antepassados. Eu nunca sofri discriminação. Eu não sei o que é, a minha pessoa. Eu vim a saber o que é discriminação a sentir na pele o que o outro sente por minha filha. Eu tenho duas filhas uma tem os cabelos cacheados e outro é loira. Então, já perguntaram se a minha filha de cabelo cacheado, que é mais velha, era babá da outra, loira.

Pesquisadora: Ela é negra, sua filha mais velha?

Manuela: É, ela tem a pele mais escura que a minha. Ela seria o que o pessoal chama de morena. Que tem a mulata, né? ...e a morena. Ela seria a morena e a outra é loira, pele branca até onde não pode mais.

Pesquisadora: São tão diferentes no fenótipo que as pessoas acham que...

Manuela: Não são irmãs. Eu tenho trabalhado muito isso com Sol, primeiro trabalhar o cabelo, né? Que as pessoas ficam: "Escova o cabelo, escova o cabelo". Eu fico: "Não Sol, seus cachos são lindos, existem princesas de cabelos cacheados sim". Porque até isso chegam a falar, que não tem princesa de cabelos cacheados. Agora Sol é bem resolvida nisso aí. Hoje ela já está com treze anos e a outra está com seis anos... Então, mas foi assim... eu senti a discriminação por causa de Sol.

Pesquisadora: Como que é o nome da outra?

Manuela: Júlia. Então, mas eu mesma nunca senti. Мeu autorreconhecimento veio por causa da minha família paterna, que tem negros na minha família paterna. Eu tenho afinidade... eu acho muito interessante o Candomblé, eu acho muito interessante a cultura afro-brasileira, essas coisas dos griôs, de você guardar, ter oralidade, como algo significativo, de você levar a sua história de vida adiante, tendo uma outra história para contar, valorizar os mais velhos, de ser a mulher a matriarca da família. Então, eu tenho as características todas... da cultura africana, não é da cultura europeia.

Manuela reconhece o quanto é difícil desenvolver um olhar crítico que permita a desconstrução de estereótipos e naturalizações sobre a população negra presentes em nossas relações, citando um exemplo em que ela mesma se vê sob a lógica perversa do racismo. Na sua experiência pessoal revela o dilaceramento que o racismo à brasileira impõe nas famílias inter-raciais: tem uma filha negra e outra branca, e ela mesma, colocando-se como negra, diz não ter sofrido discriminação e preconceitos porque seu fenótipo é branco.

Destaca que a Lei 10.639/2003 inicia um contexto novo na esfera da educação, o que, de certo modo, leva os educadores a sentirem a tratativa de questões e conteúdos que envolvem 
as relações étnico-raciais como algo que prefeririam esquecer, por conta do sofrimento que envolve, e que aparece como uma imposição do contexto escolar. Além disso, trata-se de algo que refuta ideologias internalizadas que moldaram suas concepções de mundo e sua identidade, envolvendo um repensar sobre o que entende sobre educação. Manuela reconhece a angustia presente nesse processo e a possibilidade de recuos e avanços, tendo em vista ideias e valores difundidos por outros espaços sociais, como a mídia, que podem retroalimentar preconceitos. Pensando sobre a dificuldade do professor em despertar para a necessidade de pensar sobre questões relativas à temática étnico-racial, a diretora fala de sua própria experiência, oferendo indícios de que esse despertar pode advir do entendimento dos danos do racismo para a subjetividade das pessoas negras, mesmo quando pertencem a famílias interrraciais.

Considero, pela minha própria vivência escolar, que quando o professor pensa criticamente sobre as consequências do racismo, elas geralmente são relacionadas ao social, e raramente se reflete sobre seus efeitos na subjetividade dos alunos negros ou sobre a relação que se pode fazer entre as dimensões social, individual e mesmo familiar. No caso de Manuela, advinda de um contexto familiar fortemente marcado pelo racismo, o envolvimento e a preocupação mais estreita com a questão foi abalizada pelo fato de ter sido afetada pela experiência de preconceito que atingiu sua filha. Sua narrativa leva à percepção de que este fato foi determinante para que ela buscasse conhecimentos a respeito do tema e viesse a dialogar mais intensamente com sua ascendência negra, a ponto de se autoidentificar como negra.

No contexto escolar, as ideologias racistas têm persistido como um entrave à ação do professor no sentido de pensar sobre as consequências subjetivas do racismo. Além das ideologias que circulam no ambiente escolar, o tratamento dado à educação no país acaba por limitar a condição da escola se constituir como espaço para a sensibilidade. Dessa forma, muitas situações de sofrimento acabam sendo banalizadas, sem que se reflita sobre elas, sem que os sujeitos escolares percebam o potencial de interferência de suas ações na intensificação ou transformação dessas situações. A questão de como sensibilizar é um grande desafio no trato das relações étnico-racial e de outras questões de cunho social no contexto escolar. Com relação aos professores, é importante mencionar, ademais, que as condições de trabalho e a falta de reconhecimento social interferem na identidade docente, conduzindo à perda da autoestima, o que prejudica a capacidade do professor em se reconhecer como ator social e em perceber a escola como instância onde resistências podem ser construídas.

Com relação à autoestima dos alunos negros evidencia-se, através do relato de Manuela, que a escola pode constituir lócus do seu desenvolvimento quando produz fortalecimento da 
identidade negra. O contexto escolar tem proporcionado o empoderamento dos alunos negros, o que tem contribuído para que tenham mais perspectiva em relação aos estudos e desenvolvam aspirações profissionais. Nota-se que a autoestima aparece como força motriz que leva à percepção de seus traços físicos como positivos, tanto no caso dos alunos quanto de professores. Ao promover o diálogo, a escola possibilita aos sujeitos que nela circulam repensar questões relativas à sua identidade.

De acordo com o relato mencionado, foi no momento em que se viu acolhida no contexto escolar, que a professora negra passou a referir episódios de sua vida em que foi vítima de discriminação, o que Manuela identifica como um indício de que ela estava se auto reconhecendo. A professora foi acolhida, precisamente, ao encontrar um contexto que trazia a marca da pluralidade para sua experiência singular, em que suas vivências de preconceito ganharam um caráter plural, coletivo. Dessa forma, entendemos que a escola tem construído um ambiente que se contrapõe à etiqueta das relações raciais no Brasil, que solicita, ao grupo discriminado, que negue as discriminações e, ao grupo que discrimina, que o faça de modo velado, de maneira a não colocar em dúvida a nossa "harmonia" e "cordialidade", ou, a suposta “democracia racial". A escola deve ser um espaço de acolhimento, representação e afirmação para que o sujeito sinta que, ali, suas vivências podem ser compartilhadas:

Não obstante acobertar uma forma velada de preconceito, a ideologia brasileira de
relações inter-raciais, como parte do ethos nacional, envolve uma valorização
ostensiva do igualitarismo racial, constituindo um ponto de referência para a
condenação pública de manifestações ostensivas de preconceito, bem como para o
protesto de elementos de cor contra as preterições de que se sentem vítimas.
(NOGUEIRA, 2006, p. 298).

A dificuldade em relatar episódios de discriminação pode estar relacionada à vergonha ou à dor que a lembrança da discriminação sofrida acarreta. Deve-se lembrar, no entanto que silenciar essa dor tem um custo psíquico e subjetivo elevado. No entanto, o que é enfatizado geralmente é a angústia e a humilhação que a própria narração envolve, e não, obviamente, aquilo que é reprimido. "Lembrar o sofrimento dói; lembrar que ele pode surpreender-nos na próxima esquina doí mais ainda. Motivo para que tantos negros neguem, eles próprios, que o racismo existe e os atinge" (CUTI, 2017, p. 206). Segundo Silva (2017), relatos de humilhação social são sempre acompanhados do sentimento de vergonha. A autora argumenta que a banalização dos efeitos do racismo na vida das pessoas negras decorre da invisibilidade das experiências de humilhação e, por conseguinte, dos sentimentos delas decorrentes.

Inserida em um contexto social que nega a existência de discriminações e banaliza seu sofrimento, a pessoa negra tem sua subjetividade marcada por essa denegação, e pode 
desenvolver sintomas sem os reconhecer como resultado da violência racial recebida. Para a autora, a escola tem sido lócus preferencial para o surgimento desse sentimento. Gomes (2003), por sua vez, alerta que as vivências de humilhação sofridas pelas pessoas negras no contexto escolar povoam suas memórias na vida adulta:

\begin{abstract}
As experiências de preconceito racial vividas na escola, que envolvem o corpo, o cabelo e a estética, ficam guardadas na memória do sujeito. Mesmo depois de adultos, quando adquirem maturidade e consciência racial que lhes permitem superar a introjeção do preconceito, as marcas do racismo continuam povoando a sua memória. A ausência da discussão sobre essas questões, tanto na formação dos professores quanto nas práticas desenvolvidas pelos docentes na escola básica, continua reforçando esses sentimentos e as representações negativas sobre o negro. (GOMES, 2003, p. 176).
\end{abstract}

Vemos marcado, portanto, o caráter duplo da escola enquanto espaço de reprodução de preconceitos e de construção de resistência - a escola que se abre à discussão das relações étnico-raciais se afirma como espaço de desconstrução da banalização das vivências de preconceito, tanto ao reconhecer o sofrimento e os prejuízos que o racismo causa as pessoas negras quanto ao evidenciar os sintomas dele decorrentes em sujeitos negros ou brancos. Quebrar o silêncio sobre o racismo retira a máscara que o reveste, possibilita pensarmos sobre seus efeitos em nossas relações e na formação de nossas identidades.

As situações narradas por Manuela demostram o quanto questões relativas ao corpo negro e cabelo crespo podem revelar sobre a construção do racismo, nossas relações étnicoraciais e a formação identitária. A identidade negra é uma construção social, não ocorre no isolamento, mas a partir da relação dialógica entre os sujeitos sociais nos mais variados espaços: na família, na comunidade, no trabalho, na escola, entre outros. Em uma sociedade que educa para o racismo, para a rejeição da cultura e do corpo negro, pensar, discutir e problematizar a identidade negra é preponderante para atuarmos na desconstrução de estereótipos relativos à estética negra.

Gomes (2003) assinala que na escola enquanto espaço onde crenças e valores são transmitidos e compartilhados, também aprendemos e reproduzimos estereótipos sobre o corpo negro e o cabelo crespo. Ou seja, tradicionalmente, a escola não se constituiu como espaço de revalorização da estética negra. Por conseguinte, modificar esse quadro é um grande desafio a ser superado para que se efetive a proposta de educação para a diversidade étnico-racial. Ao mesmo tempo, o fato da escola ser um espaço de transmissão e compartilhamento de valores é que lhe confere o potencial para se efetivar como instituição privilegiada de desconstrução de estereótipos e de revalorização dos símbolos identitários importantes na construção da identidade negra. 
Nesse sentido, destaca-se a importância de introduzir, no processo de formação de professores, discussões sobre as representações do corpo negro e do cabelo crespo, enfatizando a necessidade do debate no cotidiano escolar que aponte, por sua vez, para suas implicações nas relações entre os sujeitos escolares e para a forma como são produzidas e reproduzidas dentro e fora da escola:

\begin{abstract}
O estudo sobre as representações do corpo negro no cotidiano escolar poderá ser uma contribuição não só para o desvelamento do preconceito e da discriminação racial na escola como, também, poderá nos ajudar a construir estratégias pedagógicas alternativas que nos possibilitem compreender a importância do corpo na construção da identidade étnico-racial de alunos, professores negros, mestiços e brancos e como esses fatores interferem nas relações estabelecidas entre esses diferentes sujeitos no ambiente escolar (GOMES, 2003, p. 180).
\end{abstract}

A autora argumenta que há muitas semelhanças entre as formas de manipulação do cabelo e do corpo pelos negros brasileiros e aquelas desenvolvidas pelos nossos ancestrais africanos, o que evidencia a "[...] presença de aspectos inconscientes, como formas simbólicas de pensar o corpo oriundas das diversas etnias africanas das quais somos herdeiros e que não se perderam totalmente na experiência da diáspora" ${ }^{" 107}$. Portanto, essas formas de manipulação nos põem em contato com a nossa herança africana, pois denotam a presença de elementos culturais africanos ressignificados na atualidade brasileira, devendo fazer parte tanto dos currículos quanto dos processos de formação de professores.

Quando a escola se abre ao compromisso de problematizar a identidade negra e quilombola, se torna espaço de ressignificação do "ser negro" e "quilombola". Percebemos que esta problemática está presente na escola quilombola pesquisada, ficando evidenciada a preocupação em torno da revalorização da estética para o desenvolvimento da autoestima dos alunos. Nota-se, pelas situações descritas por Manuela, que circula entre sujeitos a visão preponderante no imaginário social de que, para ser negro, é necessário reunir duas características: a pele negra e o cabelo crespo. Nesse sentido, há dificuldade de alguns professores negros se autoidentificarem, por terem o cabelo liso. No imaginário social, o cabelo crespo se configura como símbolo estético negro estigmatizado, tido como inferior ao cabelo liso, frequentemente associado à estética branca.

Dessa forma, como a fala de Manuela sugere, o cabelo liso pode, muitas vezes, servir para se afastar da negatividade vinculada a "ser negro", na medida em que possibilita ao sujeito utilizar-se de outros termos para se autodefinir, como moreno, caboclo - a exemplo do caso do meu pai e do pai de Manuela - ou como pardo - como no caso do professor Júlio. Fundamental

${ }^{107}$ Ibid., p. 174. 
assinalar que esse afastamento do "ser negro", a partir do apego a certas marcas, reconhecidas como correspondentes à estética branca, não consiste em simples evidência de uma postura individual, ela é forjada socialmente. No Brasil, são bastante comuns enunciados do tipo "Não, você não é negra, você é morena", que designam negação do "ser negro" ao outro que enuncia sua afirmação identitária. No contexto atual, em que evidenciamos uma reafirmação significativa da estética negra, a sala de aula tem nos oferecidos inúmeros exemplos de como na retomada do cabelo crespo, como marca reconhecida da estética negra, o sujeito enfrenta resistências do entorno.

Vale aqui fazer algumas colocações sobre a nossa conversa com o professor Júlio. Ele assinalou não concordar com a implementação do Currículo Quilombola na escola, considerando a postura da direção autoritária - "quer que a gente engulha esse projeto, isso aqui é uma ditadura”. Segundo ele, não se deve ter um currículo com ênfase na história e cultura afro-brasileira e africana ou de quilombos, pois a escola é frequentada por pessoas de todas as cores, religiões e oriundas de outras comunidades, não apenas da comunidade de Barro Preto. Durante a conversa, procurou justificar sua opinião dizendo que "Não somos negros e nem brancos, somos todos mestiços e multiculturais". Havia, em seu discurso, um forte apelo à miscigenação, à "mistura de raças", como prova incontestável de que não é possível determinar quem é negro ou branco pois, de seu ponto de vista, existiriam brancos apenas na Alemanha, referindo-se à expressão "raça ariana".

O discurso de Júlio é cheio de ambiguidades e contradições. Mesmo ressaltando o aspecto multicultural da escola e da sociedade brasileira, o faz no sentido de justificar a sua não concordância com um currículo que aborde as matrizes afro-brasileiras e africanas. $\mathrm{O}$ termo "multicultural" em sua fala foi associado ao sincretismo cultural e religioso, à miscigenação. E esta foi associada à 'brasilidade", com a ideia de que "somos todos, mestiços, pluriculturais, somos todos brasileiros".

O discurso do professor banaliza o racismo anti-negro quando diz que o negro não é o único atingido por preconceitos no Brasil, que as pessoas negras se discriminam mutualmente e que existe o racismo negro contra as pessoas brancas. Esse caso demostra a força das ideologias raciais e a ameaça que a reprodução desse tipo de discurso, em sala de aula, representa para o fortalecimento da escola como espaço de ressignificação. Ao mesmo tempo, fica evidenciada a necessidade de formação do professor, para que possa se desvencilhar desses falsos silogismos e aprenda a reconhecer o que eles trazem como reforço da opressão, ao culpar as próprias vítimas e ao não reconhecer as diferentes posições de poder. Enfim, para que em 
sua prática educativa a abordagem das relações étnico-raciais não se constitua em simples ratificação de estereótipos e generalizações.

Oliva (2012) explica que a identidade nacional não pode ser pensada em termos de homogeneidade ou inscrição cultural/identitária:

\begin{abstract}
Não estamos afirmando com isso que não temos 'uma identidade nacional'. 'Ela' ou 'elas' existem. Inscrevemo-nos na 'brasilidade' ou a refletimos em algumas situações, como já afirmamos. Porém, mesmo nesses momentos, 'ela' ou 'elas' não nos igualam. Enfim, somos brasileiros (para aqueles que se consideram ou se inscrevem nesta identidade), mas possuímos outras inscrições identitárias, mais reveladoras, marcantes e coparticipantes em relação à primeira quando operamos as categorias de definição e identificação. Perceba-se, portanto, que não defendemos um revirar de faces ou identidades, apenas reforçamos o argumento de que a definição 'brasileiro(a)' só pode ser entendida quando vista como um mosaico, composto por outras múltiplas faces, por diversas culturas, com a presença de maiorias e minorias. Identidades Plurais que se articulam, se atraem ou se rejeitam sob um 'guarda-chuva' identitário maior, a Identidade Nacional. Cada vez mais, para mais pessoas, faz mais sentido se pensar como nipo-brasileiro ou afro-brasileiro, do que como apenas 'brasileiro' (OLIVA, 2012, p. 33)
\end{abstract}

Um dos desafios da escola é não deixar que as várias formas de identidades presentes continuem a ser invisibilizadas e silenciadas em nome da 'brasilidade'. Aliás, discursos que exaltam a identidade nacional, com frequência negam as contribuições, produções culturais, políticas, econômicas, sociais, artísticas de negros e indígenas em sua formação. "Não há identidade brasileira sem identidades negras, índia e mestiça livres dos padrões hegemônicos brancos" (CUTI, 2017, p. 211).

O racismo perambula pela história e reatualiza suas marcas através de narrativas eurocêntricas. A lógica racista, ao associar historicamente o corpo negro à subalternidade, produz subjugação, o que entrava e espolia a subjetividade das pessoas negras (JUNIOR, 2017, p. 177). Como erva daninha, o racismo se ramifica e se reatualiza entre as gerações. Concordamos com Gonçalves Filho (2017, p. 144) quando afirma o racismo como um golpe desenfreado, pois a pessoa negra:

[...] sofre o golpe prolongado do racismo. Sofre o racismo disparado agora e o de antes. Sofre o golpe direto, o golpe próximo, o golpe que o atinge aqui e ao redor. Sofre na cidade, no trabalho. Sofre o racismo contra seus familiares, contra seus companheiros de raça. E sofre o golpe antigo, disparado contra seus ascendentes, o golpe operado contra seus ancestrais e que segue operando, à distância, a partir de um ponto distante, lá atrás, que recua e que pode recuar no passado, mas que volta por herança.

Se por um lado, o golpe do racismo é reatualizado, por outro lado, a nossa herança cultural africana e afro-brasileira constitui-se em arma de combate - no momento em que se introduz no currículo a história e culturas afro-brasileira e africana cria-se a possibilidade de 
desmitificar a história, resgatar nossa herança cultural pela recuperação de memórias perdidas e silenciadas dos nossos antepassados:

\begin{abstract}
O ensino de História e Cultura Afro-Brasileira e Africana, evitando-se distorções, envolverá articulação entre passado, presente e futuro no âmbito de experiências construções e pensamentos produzidos em diferentes circunstâncias e realidades do povo negro. É um meio privilegiado para a educação das relações étnico-raciais e tem por objetivos o reconhecimento e valorização da identidade, história e cultura dos afro-brasileiros e igual valorização das raízes africanas da nação brasileira, ao lado das indígenas, européias, asiáticas [...] (BRASIL, 2004b, p. 20).
\end{abstract}

As mudanças trazidas pelas novas diretrizes curriculares, que estabelecem a obrigatoriedade do ensino de história e culturas afro-brasileira e africana precisam envolver uma mudança de perspectiva. Pereira e Roza (2012) assinalam que as pressões do combate ao racismo forçam a uma reconfiguração das narrativas históricas e nos colocam diante de uma reescrita da história. Esse movimento de reconfiguração traz a necessidade de positivação de memórias e histórias silenciadas que não deve, no entanto, ser entendida como retirada de conteúdos relativos à escravidão e à violência dela resultantes, ou como abordagens idealizadas ou mitificadas da história afro-brasileira e africana.

Positivar não significa suprimir do currículo conteúdos relativos à escravidão, mas ressaltar vozes silenciadas, que revelam as múltiplas formas de resistência, organização e modo de vida da população negra. “[...] O dever de memória não poderá impedir o direito à história. $\mathrm{O}$ direito à história, com todas as faces dessa história que envolveu lutas, resistências, submissões e violências". (PEREIRA; ROZA, 2012, p. 116).

A apresentação do povo negro como protagonista, como sujeito de resistência, subverte a lógica racista que atrela seu corpo à submissão, possibilitando que ele seja visto como sujeito de contestação. Nessa perspectiva, as DCNS para ERER salientam a necessidade de: “[...] divulgação e estudo da participação dos africanos e de seus descendentes em episódios da história do Brasil, na construção econômica, social e cultural da nação, destacando-se a atuação de negros em diferentes áreas do conhecimento, de atuação profissional, de criação tecnológica e artística, de luta social”. (BRASIL, 2004b, p. 22).

Perceber o grupo do qual descende como sujeito histórico permite à pessoa negra fazer uma releitura sobre sua própria história, corpo e identidade, o que colabora para o desenvolvimento de sua autoestima. De acordo com as Diretrizes Curriculares Estaduais para a Educação Escolar Quilombola, essa articulação entre identidade, protagonismo negro e quilombola é central na organização do currículo. Desse modo, o currículo da Educação Escolar Quilombola deverá: 
I garantir ao educando o direito a conhecer o conceito, a história dos quilombos no Brasil e na Bahia, o protagonismo do movimento quilombola e do movimento negro, assim como seu histórico de lutas; II implementar a Educação das Relações ÉtnicoRaciais e o Ensino de História e Cultura Afro-brasileira, Africana e Indígena, nos termos da legislação em vigor; III reconhecer a história e a cultura afro-brasileira como elementos estruturantes do processo civilizatório nacional e regional, considerando as mudanças, as recriações e as ressignificações históricas e socioculturais que fundamentam as concepções de vida dos afro-brasileiros na diáspora africana; IV promover o fortalecimento da identidade étnico-racial, da história e cultura afro-brasileira e africana ressignificada, recriada e reterritorializada nos espaços quilombolas; V garantir a discussões sobre a identidade, a cultura e a linguagem, como eixos norteadores de currículo. (BRASIL, 2013b).

Enfatizamos a importância do estudo de quilombos para a superação do imaginário negativo acerca de "ser quilombola". Há uma série de estudos ${ }^{108}$ que podem auxiliar na desmitificação de ideias enrijecidas no senso comum e que povoam o imaginário social, ideias que- associam quilombo à marginalidade ou o reconhecem apenas como aglomerado de negros em fuga, lugar isolado na mata. Esses estudos revelam as complexas relações e dimensões que envolveram a história de quilombos no Brasil; permitem entender que foram várias as formas de aquilombamento (modo de negociação, acomodação, conflito e resistência); desmitificam a ideia de isolamento, apresentando as conexões que os quilombos mantinham com os vários setores e grupos sociais (escravizados, homens livres, senhores escravocratas, indígenas) e o modo como foram interferindo e sendo afetados pelos contextos socioeconômicos, geográficos, políticos e culturais que se estabeleceram. Conforme salienta Reis e Gomes (1996, p. 23):

Os quilombos brasileiros ocuparam sertões e florestas, cercaram e penetraram em cidades, vilas, garimpos, engenhos e fazendas; foram atacados e usados por grupos escravistas, aos quais também atacaram e usaram em causa própria; fugiram da escravidão e se comprometeram com a escravidão; combateram e se aliaram com outros negros, índios e brancos pobres; criaram economias próprias e muitas vezes prosperas; formaram grupos pequenos, ágeis, moveis e temporários, ou grupos maiores, sedentários, com gerações que se sucediam, politicamente estruturados; envolveram-se com movimentos políticos de outros setores sociais, desenvolveram seus próprios movimentos, alguns abolicionistas; aproveitaram-se de conjunturas políticas conflitivas nacionais, regionais, até internacionais, para crescer, ampliar alianças, fazer avançar seus interesses imediatos e projetos de liberdade mais ambiciosos.

Ressaltamos também a importância do entendimento dos quilombos na contemporaneidade, o conhecimento sobre as comunidades quilombolas rurais e urbanas, suas especificidades, e as relações dentro dos contextos políticos, sociais e econômicos nos quais desenvolvem suas lutas pelo acesso à terra, pela afirmação enquanto sujeito de direito, pela preservação de seus costumes, práticas culturais e combate ao racismo. Torna-se de

${ }^{108}$ Como indicação de alguns desses preciosos estudos, sugerimos: REIS, J. J. G; GOMES, F. dos S. (Orgs.), Liberdade por um fio. História dos Quilombos no Brasil. São Paulo, Cia. das Letras, 1996. 
fundamental relevância também empreender a compreensão do significado do quilombo e seus sentidos simbólico e político no percurso do movimento negro e quilombola, assim como a atuação desses movimentos nas esferas política e educacional e os impactos de suas ações nos cenários regionais, estaduais e nacional.

A esse respeito, a fala de Manuela nos revela que a presença de membros da comunidade no quadro de funcionários é algo que tem contribuído para a elevação da autoestima e valorização da cultura afro-brasileira entre os alunos. Em conversa posterior à entrevista, Manuela relatou que acredita que a presença de pessoas oriundas da comunidade na escola serve como elemento provocador que pode levar o professor a perceber a necessidade de rever sua prática educativa. Segundo Manuela, há somente um professor (não efetivo) oriundo da comunidade, os demais não fazem parte dela. Esse fato pode, em parte, fazer compreender as dificuldades particulares enfrentadas pelos professores para lidar com as mudanças empreendidas na escola. É difícil a construção de uma escola quilombola com professores e funcionários que não o são. As Diretrizes Curriculares para a Educação Escolar Quilombola orientam para que: "presença preferencial de professores e gestores quilombolas nas escolas quilombolas e nas escolas que recebam estudantes oriundos de territórios quilombolas" (BRASIL, 2012, Art. $6^{\circ}$. III - p. 15).

A interação entre professores e comunidade quilombola é algo ressaltado como de extrema relevância nas Diretrizes Curriculares Nacionais Para a Educação Escolar Quilombola - o currículo quilombola deve ser construído em diálogo com a comunidade e as ações educacionais e projetos pedagógicos devem dialogar com a sua história e cultura, com respeito às suas tradições, seus valores e práticas culturais.

\footnotetext{
Art 6. V implementação de um currículo escolar aberto, flexível e de caráter interdisciplinar, elaborado de modo a articular o conhecimento escolar e os conhecimentos construídos pelas comunidades quilombolas, referendado em um projeto político-pedagógico, que considere as especificidades históricas, culturais, sociais, políticas, econômicas e identitárias das comunidades quilombolas (BRASIL, 2012b, p. 15).

Art 14. III a articulação entre os conhecimentos científicos, os conhecimentos tradicionais e as práticas socioculturais próprias das comunidades quilombolas, em processo educativo dialógico e emancipatório (BRASIL, 2012b, p. 20)
}

Essa articulação entre comunidade e escola é importante para que os alunos se reconheçam como parte integrante do processo de construção de conhecimentos, a partir do pressuposto de que conhecer é um processo ativo que não se limita à simples absorção de conhecimentos formais produzidos. Manuela expõe a forma com que a escola tem procurado fazer essa interação entre alunos, professores e comunidade quilombola: 
Pesquisadora: Essa questão da oralidade é trabalhada na escola? Como que é a relação da comunidade escolar com a comunidade do Barro Preto?

Manuela: A gente traz as pessoas da comunidade e a gente visita as comunidades. Em todos os projetos eu peço para os professores que incluam um passeio pela comunidade, para que o estudante tenha aquele olhar não como morador, mas aquele olhar de quem está de fora, olhar de pesquisador. Toda jornada pedagógica a gente caminha pela comunidade, vê a problemática da comunidade para também despertar no nosso estudante que nós não queremos sair da comunidade. Nós queremos que a comunidade desperte para que ela tenha os direitos merecidos, adquiridos. Então, que ela tenha calçamento, que ela tenha urbanização adequada, que ela proteja as suas árvores, que ela cuide melhor do seu rio. Então, você não tem que ficar escolarizado e sair da comunidade. Você tem que ficar escolarizado e ficar na comunidade para reconstruir sem perder as raízes. Que é o mais difícil.

Pesquisadora: Tem momentos em que há atividades para o trabalho com a oralidade de pessoas da comunidade?

Manuela: Tem uma das reuniões do colegiado escolar. Tem um mês que a gente não se reuni. Tem a participação de moradores e eles fazem muitos relatos de líderes e vice-líderes de classe que são os que participam do nosso colegiado escolar.

Pesquisadora: Os alunos...todas as séries têm dois?

Manuela: Isso, todas as séries têm dois que são eleitos como aqueles que vão votar, caso precise votar alguma lei, alguma implementação na escola. Tem algum problema na escola e aí a gente precisa resolver.

Com relação a projetos realizados pela escola, estão marcados pela perspectiva de interação comunidade escolar/comunidade de Barro Preto, visando: que os alunos possam desenvolver capacidade de análise e de tomada de decisões; olhar crítico sob a realidade de sua comunidade e diagnóstico de suas necessidades cotidianas; desenvolvimento de sentimento de pertencimento e valorização da comunidade; valorização da escolarização como meio de desenvolver suas potencialidades socioeducacionais, reconstruir seu patrimônio cultural e contribuir para a transformação da realidade social na qual se encontra inserido. Espera-se, ainda, que a interação possa proporcionar a conscientização política dos envolvidos, de modo a reconhecerem as demandas coletivas e se perceberem como sujeitos de direito. Essa perspectiva salienta a função social da escola, seu papel potencial para a construção da identidade quilombola e para a emergência da comunidade como sujeito político que reivindique seus direitos.

Esse exercício de percorrer a comunidade com o olhar de pesquisador oportuniza “[...] valorização dos conhecimentos tradicionais produzidos pela comunidade e aprendizado de diversos conhecimentos necessários ao aprofundamento das suas interações com seu grupo de pertencimento e com a sociedade mais ampla” (BRASIL, 2012b, p. 25). Além disso, constitui uma prática importante para que se exercite um dos princípios que regem a Educação Escolar Quilombola:

XVI - direito dos estudantes, dos profissionais da educação e da comunidade de se apropriarem dos conhecimentos tradicionais e das suas formas de produção das comunidades quilombolas, de modo a contribuir para seu reconhecimento, valorização e continuidade; (BRASIL, 2012b, p. 10). 
As Diretrizes Curriculares Nacionais para EEQ orientam que as práticas pedagógicas proporcionem “[...] a elaboração e uso de materiais didáticos e de apoio pedagógico produzidos no percurso formativo dos alunos, com conteúdos culturais sociais, políticos e identitários específicos das comunidades quilombolas" (BRASIL, 2012b, Art 33. VI, p. 30). Ao evocar que os conhecimentos da comunidade sejam sistematizados por meio de materiais didáticos, o documento parece sugerir que conhecimentos orais sejam elaborados e transformados em escrita. Nesse caso, os conhecimentos orais se tornariam conhecimentos transmitidos fora de seu contexto tradicional. Nesse ponto deve-se ter cautela, para que isso não implique em substituir a participação da comunidade no contexto escolar e para que a escrita não venha a ser ainda mais privilegiada e posta como único meio legítimo de preservação e de transmissão de saberes tradicionais.

$\mathrm{O}$ trato da oralidade ressignifica o entendimento sobre o que se compreende como conhecimento escolar, abre espaço para o "currículo invisível" relacionado às experiências socioculturais da comunidade quilombola (MOURA, 2006). A oralidade é destacada em um dos princípios relacionados à Educação Escolar Quilombola, expostos nas DCNs para EEQ: "XX cultivo e valorização da tradição oral, da memória histórica afro-brasileira, da ancestralidade e da erudição popular dos "mais velhos" como fonte de conhecimento e pesquisa e como conteúdo da Educação Escolar Quilombola" (BRASIL, 2012b, p. 14).

Oportunizar aos alunos troca de vivências e experiências com os "mais velhos" é importante para a desconstrução da noção de "sujeito histórico" atrelada à ótica eurocêntrica, que se assenta na ideia de que o branco é o único produtor de cultura e história. Pereira e Roza (2012) argumentam que a ênfase nas narrativas enaltece o valor das memórias e o direito à fala de grupos invisibilizados historicamente, proporcionando ampliação da noção do sujeito histórico, de que cada um é sujeito histórico produtor e produto de cultura e história.

Tal ênfase auxilia os sujeitos a perceberem que não existe uma única forma de produzir ou transmitir conhecimentos e que, por conseguinte, não se pode estabelecer uma hierarquização entre os saberes e práticas culturais de diferentes grupos sociais; corrobora para a apreender a importância da oralidade como fonte histórica e o valor da transmissão do conhecimento intergeracional. Conforme salientam os autores, a ênfase na palavra e na escuta pode produzir em todos os sujeitos envolvidos nas práticas educativas mudança de postura e compreensão com relação às práticas culturais afro-brasileiras presentes nas comunidades quilombolas: 
Ao fazer recair a centralidade do ato educativo sobre a palavra falada e ouvida, os professores também afirmam alterações na compreensão do que são as culturas afrobrasileiras. Abordadas por sua permanência no presente, como tradições vivas, e disponíveis nos arcabouços culturais vigentes, sujeitos às interpretações, aos pontos de vista e ao crivo das biografias. Há uma dimensão experiencial nas circunstâncias de fala e escuta, sendo ambos os movimentos educativos para todos os envolvidos numa roda. A troca de experiências entre estudantes e mestres pode proporcionar o exercício do deslocamento, movimento que exige ir de um ponto a outro, alterando concepções anteriores e possibilitando que todos os envolvidos compreendam essas práticas culturais sob outras óticas. (PEREIRA; ROZA, 2012, p. 97).

Para Manuela, é possível perceber mudanças significativas produzidas pela valorização das culturas africana e afro-brasileira não somente com relação aos alunos, mas também em seus familiares. Ou seja, as práticas educativas que favorecem as trocas com a comunidade se estendem para além do ambiente propriamente educacional:

\begin{abstract}
Pesquisadora: Que pontos você colocaria como importantes na relação entre vivência do aluno aqui na escola e a casa dele?

Manuela: Tem mães que vêm aqui, relatam a mudança que o menino está tendo, que assumiu o cabelo. As meninas que assumiram o cabelo afro, as mães vêm aqui reclamar, né? ...dizer que não está dando certo isso. Por outro lado, eles começam a relatar a transformação na casa, que as mães começam a enxergar a cultura africana como positivo. Os relatos, elas conversando com a gente... eu já percebo, principalmente o empoderamento de entrar na escola se sentindo pertencente à escola. Elas entravam aqui cabisbaixa, eu era a autoridade e eles teriam que me ouvir. Hoje elas já entram aqui conversando. $\mathrm{Na}$ semana passada teve uma que ficou me aguardando lá fora, eu disse: "Porque a senhora não entrou?" E ela: "Ah o porteiro disse que não podia entrar". Eu: "Mas se a casa é sua? Cadê o seu empoderamento? Você tem que chegar na escola: "Esse é o meu espaço". Então, esse empoderamento a gente já percebe nas mães e na valorização também, na formação informal do neto, que aqui são mais avós, né? As mães saem para trabalhar e os meninos são criados pelas avós. E as avós já começam a perceber que mesmo sem a escolarização, esta formal, eles contribuíram para a formação do menino. Porque eles não sentiam essa contribuição. É como se toda a história, tudo que eles passaram para o menino não tivesse valor nenhum, entendeu? A sua vivência era desvalorizada, toda sua cultura era desvalorizada. Aí, a gente tem esse negócio das ervas mesmo. O Ossain o ano passado, na época em que a gente montou, a gente falava com a mães sobre a importância do chá caseiro que a mãe ensina, que você não precisa ter ido 0 escola para saber muita coisa, que todo saber é valorizado.

Pesquisadora: Isso era feito mais em que momento?

Manuela: Nas reuniões. Eu trabalho muito nas reuniões com os pais. E eu pensei que esse ano o projeto Ossain fosse trabalhar isso de forma mais sistemática. Tanto que eu passei para uma professora e o projeto morre!? É um filho, sabe?... Parece que estou vendo um filho morrendo. E ele vai ficar na UTI este ano todo, porque eu só posso retomar ele em 2016. Ele tem que ficar com a professora até 2016.
\end{abstract}

Ainda que haja, por parte de alguns, uma inquietação ou postura negativa com relação aos filhos assumirem o afro, por outro, há posturas positivas - como a com que os pais se relacionam com a escola - que evidenciam que o trabalho da escola tem efeitos significativos na elevação da autoestima de membros da comunidade, e de que os pais e avós estão se identificando com a escola por se perceberem representados e valorizados no contexto escolar. 


\section{A seguir, Manuela fala sobre a dificuldade em reformular o projeto político-pedagógico}

da escola, assim como em realizar projetos que a ele se articulem enfatizando, mais uma vez, a necessidade de participação dos professores na sua elaboração e efetivação:

Pesquisadora: Então, você falou da implementação das disciplinas, que não deu certo... e a implementação do projeto político pedagógico?

Manuela: O projeto político pedagógico tem uma resistência em todas as escolas e na nossa mais ainda porque ele é exigido. Tanto que agora ele está sendo reformulado. A cada dois anos ele precisa ser reformulado. E nós trabalhamos dois sábados letivos para que o professor reformulasse dentro da sua área o PPP. Ele não fez nada. Quando eu pedi agora para entregar, ele não fez. Então, poucos conhecem. Tanto que eu fiz um banner com a missão da escola e com a visão, porque eles não conseguiam saber nem a visão nem a missão da escola. Eu falei: "Gente eu vou colocar" e coloquei também na minha... botei essa semana na minha assinatura eletrônica de e-mail, porque, como eu mando muito e-mail para os professores, eles vão começar a ver e quem sabe com isso memorizar. Então, o PPP não é um instrumento bem trabalhado ainda em nenhuma escola, nem pública nem particular. Então, nosso PPP ele é muito bem elaborado, até porque a primeira construção dele iniciou nessa especialização minha junto com o ODERE, ele foi revisto em uma especialização também que eu fiz junto com Maria na UFBA e tendo os professores como objeto de pesquisa. Agora eu nunca vi o professor lendo, eu que coloco assim: "Você viu no PPP?". Ele não viu. Então, ele é implementado de forma... sem o professor saber que é o PPP que está atuando. E assim, eu também vejo que a educação coloca no PPP da escola algo que ele ainda não consegue abarcar. Eu liguei para a secretaria da educação para falar de um problema que eu tenho com a professora de educação física, que ela se recusa a trabalhar jogos na escola e se recusa a trabalhar a história da capoeira com os estudantes. "Ah senhora não colocou isso no PPP da escola não?". Eu disse: "Desde quando uma lei no Brasil é cumprida?" Eu falei: “José se não é cumprida a lei federal, você acha que uma lei escolar que é o PPP vai ser cumprida? Que pergunta é essa?". Eu fico indignada. Então, existir um PPP está tão longe da efetivação desse PPP quanto a Bahia de São Paulo ou vou dizer a Bahia da África. Você tem que atravessar um continente. Então, ele pode estar muito bem feito, muito bem organizado. Eu já pensei e até falei com Maria, eu falei: "Esse ano, com essa reformulação, eu preciso fazer um resumo do PPP e fazer um banner e começar a colocar na quadra, sabe? ...uns adesivos, sabe? ...plotar a escola com o PPP. Não é?" Falei: "Nessa revisão agora a gente precisa plotar o nosso PPP”.

Pesquisadora: Com relação à capoeira, que você falou, tem a prática aqui na escola? Manuela: Tem, ela está parada agora, porque está sem recurso do Mais Educação. Mas temos diversos alunos capoeiristas, temos um professor que é ligado. Já tivemos o batizado da capoeira duas vezes aqui na escola.

Pesquisadora: Com relação às oficinas, há algumas?

Manuela: Tem, elas são realizadas durante a semana em turno oposto. Mas as oficinas estão paradas há dois meses porque o recurso esse ano...

Pesquisadora: É do Mais Educação o recurso?

Manuela: É do Mais Educação.

Pesquisadoras: E como são essas oficinas?

Manuela: Essas oficinas são trabalhadas: a de língua portuguesa, com o projeto de leitura, onde é trabalhada a cultura africana dentro da literatura, né? ...no letramento com livros. Inclusive os livros, eu pedi para trabalhar no regular, porque, como o Mais Educação está parado, eu pedi para trazer para o regular. E a professora Mirela está trabalhando com os contos africanos. Aí, temos a oficina de matemática, que não é ligada a etnomatemática porque a professora oficineira não tem esse acompanhamento. Temos a oficina de capoeira, temos a oficina de promoção a saúde, temos a oficina da rádio escolar, que tem estudantes como voluntários, temos as oficinas de esporte.

Pesquisadora: Por parte dos alunos há proposta de realização de projetos sobre identidade quilombola, matrizes africanas etc.

Manuela: $\mathrm{O}$ ano passado tivemos duas gincanas e nessa gincana estudamos os países africanos. Cada equipe tinha o nome de um país africano e ele ia estudar a cultura 
desse país e iria apresentar. E esse ano, se eu não me engano, também na gincana desse ano, do projeto drogas, tem alguma coisa. Maria comentou alguma coisa contigo?

Pesquisadora: Sim.

Manuela: Mas ela falou se tem essa...

Pesquisadora: Não me lembro.

Manuela: Mas acho que o Projeto Droga tem alguma coisa que aborda a cultura afrobrasileira. Temos um outro que promove realmente junto com a cultura afro, que é o Projeto Ossãim, que é um orixá que cuida das ervas medicinais, por isso que foi dado o nome ao projeto. $\mathrm{O}$ projeto é sobre a horta, agricultura, meio ambiente. $\mathrm{O}$ projeto foi muito bem feito no papel e aí eu dei a carga horária para a professora Nina. Retirei ela de sala de aula três horas aulas por semana para ela trabalhar esse projeto. Me pergunte quantas linhas eu tenho de efetivação desse projeto. Sabe quantas linhas eu tenho? [Pega o documento na gaveta e lê] Duas linhas dizendo assim oh: "Foi citado o Projeto Ossãim pela professora para sua participação, que socializou seus planos de aula com articulação do projeto". A única coisa que eu tenho do Ossãim é isso aqui. Pesquisadora: Ele não ocorreu então?

Manuela: Ainda não. Ele era para estar acontecendo agora na terceira e quarta unidade. Eu vou conversar com a professora novamente se ele vai ser feito mesmo.

Pesquisadora: Tem o espaço para horta?

Manuela: A horta está linda? você não viu a horta não?

Pesquisadora: Ainda não? eu vou hoje ainda.

Manuela: Quem cuida da horta é IRA e um funcionário nosso, seu Geraldo, alguns alunos estão cuidando e a professora Dora. A professora Dora vai com alguns alunos cuidar. O Mais Educação também já trabalhou com a horta, foi a época em que a nossa horta foi mais bonita aqui, foi na época em que a professora Dora estava.

[...]

Pesquisadora: De que forma é trabalhada a história do bairro na escola?

Manuela: Através de projetos. $\mathrm{O}$ ano passado trabalhamos com projetos e esse ano nós estamos também pedindo desde o início do ano. No início do ano nós pedimos aos professores, fizemos a jornada pedagógica. Aqui na Bahia nós temos os projetos estruturantes, que é o Face, que trabalha com música, o AVI, que trabalha com artes visuais, o EPA, que trabalha com patrimônio cultural, o PROVI, que trabalha com vídeo, o Dance, que trabalha com dança, e o ENCANTE, que trabalha com coral. Então, eu coloquei junto com os professores, eles concordaram que iriam trabalhar a história do bairro dentro desses projetos. Então, artes visuais seria relacionado a quadros pintados a partir da visão artística que o estudante tem da comunidade, patrimônio cultural, seria encontrado patrimônio cultural dentro da comunidade, o vídeo seria sobre experiências da comunidade... Então, todos os estruturantes... a letra da música falando sobre essa realidade. Só que ele foi trabalhado de forma pouco sistematizada, tanto que o EPA acabou sendo feito por mim; o professor desistiu no meio do caminho e aí eu, junto com alguns estudantes, fui até a Caixa d'água. Você conheceu a Caixa d'água?

Pesquisadora: Vou hoje conhecer.

Manuela: A Caixa d'água, que foi onde o trem parava para abastecer, né? ...na rua da linha. Então, eu fui junto com eles e orientei, e inclusive está até na final. Então, uma coisa que era simples de sair...O professor que ficou com PROVI, o projeto dele era maravilhoso, era para fazer um comparativo, entrevistar ex-alunas da escola quilombola que estavam na universidade e de outras escolas públicas e comparar como é essa relação hoje com a universidade, ver como a escola Milton Santos contribuiu e outras duas escolas contribuíram para o acesso à universidade. Ele deixou no meio do caminho. [...] Temos "Letras no quilombo" que foi também um outro projeto daqui belíssimo, da literatura negra, de declamação de poemas que falam sobre a resistência da cultura afro-brasileira, a história do negro no Brasil e no mundo, falar sobre poetas negros... morreu. Morreu porque...

Pesquisadora: Esse chegou a ocorrer ou não?

Manuela: Ele foi feito e foi nota dez. Tanto que no projeto desse ano eu pedi para colocar "Oh, gente, coloca como projeto o segundo "Letras no quilombo"”. 
Quanto aos projetos e oficinas, apesar de vários serem realizados, a desistência do professor durante o processo surge como um aspecto importante a ser problematizado, quando se pensa na continuidade das mudanças empreendidas a partir da gestão escolar. Exemplo disso foi a interrupção do projeto Ossãim ${ }^{109}$, que tinha como intuito trabalhar de forma mais sistematizada os saberes da comunidade sobre as ervas medicinais. Mais uma vez, ficam marcados os entraves do professor em trabalhar as questões relacionadas às relações étnicoraciais e o currículo quilombola, que não se relacionam exclusivamente ao preconceito, como o caso da professora que se negou a introduzir em suas aulas a prática da capoeira. Mas se relacionam também ao distanciamento entre o que é exigido ou demandado e a realidade concreta de sua formação, como o caso da professora que deveria lecionar etnomatemática. Como exigir do professor, algo que ele não tem formação para realizar? Além disso, a formalização de temáticas, como etnomatematica e saberes tradicionais (ervas medicinais) em saber escolar não é tarefa fácil. Há também a problemática que envolve recursos financeiros, na maioria das vezes a escola não os tem de maneira regular ou suficiente para o desenvolvimento de projetos e oficinas, como sinalizado por Manuela quando diz que algumas oficinas não estavam ocorrendo pela interrupção de recursos provenientes do "Mais Educação". Existente demandas de secretarias educacionais que a escola se vê impossibilitada de cumprir.

Em entrevista com os alunos, foi possível verificar em quais atividades escolares percebiam a introdução da cultura africana e afro-brasileira. Eles citaram mudanças na alimentação e no ambiente, que passou a ser decorado com pinturas e esculturas, confeccionadas por eles mesmos. Esses materiais produzidos, segundo os depoentes, estão relacionados às africanidades, assim como as exposições de trabalhos, projetos, oficinas de dança, teatro e discussões em sala de aula, embora não frequentes:

Pesquisadora: Em quais atividades da escola vocês percebem a introdução da cultura africana e afro-brasileira?

Makbo: Começa desde a comida, né?

Dudu: Isso

Oré: A gente tem até livros aqui que falam dessa questão.

Dudu: Aqui tanto o ambiente físico... o ambiente tenta trazer todo aquele clima, toda aquela coisa de... digamos assim... aquele ar de ambiente quilombola mesmo, tanto as esculturas. Não sei se você reparou... As esculturas, os vasos, as pinturas, até mesmo o diálogo.

Pesquisadora: São feitas pelos alunos mesmo?

Dudu: Isso, grande parte das pinturas sim... Então, até certos termos utilizados na fala traz a presença disso, traz isso, resgata isso de certa forma. E na sala de aula não é

\footnotetext{
${ }^{109}$ Segundo Gomes (2012, p. 282), Ossãim é uma das plantas litúrgicas do Candomblé. "Na mitologia iorubana, Ossãim é o senhor das folhas: dele advém o domínio da natureza, originando um culto especial dirigido pelo babalossãim. Entretanto, embora Ossãim seja o dono de todo o reino vegetal, cada orixá tem suas plantas, denominadas folhas votivas. No terreiro, as pessoas encarregadas dos cuidados com as plantas, sua coleta e preparo, recebe o nome de yalossaim (mulheres) ou babalossaim (homens).".
} 
diferente, volta e meia estamos tratando sobre esse assunto, estamos tratando sobre esse tema. Como foi o caso agora, teve um curso de extensão em educação quilombola.

Odara: Está tendo, né?

Dudu: Está tendo ainda, né? E abriu espaços para as pessoas se inscreverem. Então, abriu espaços para os alunos se inscreverem nesse projeto, para explicar tanto historicamente como socialmente a formação aqui da comunidade. Então, isso está sempre presente aqui na escola, tipo assim, não é ser quilombola no papel e esquecer... Odara: As oficinas também...

Dudu: Isso, as oficinas e projetos.

Pesquisadora: Que tipo de oficinas vocês têm aqui?

Makbo: Capoeira, artesanato, artes de expressão, teatro...

Dudu: A oficina do turbante...

Odara: Dança, cabelo, escultura... empoderamento crespo.

Pesquisadora: $\mathrm{O}$ ano todo tem essas oficinas?

Dudu: Isso, sempre está tendo.

Oré: Até o projeto Mais Educação...

Dudu: Até o projeto Mais Educação, embora o governo tenha cancelado aqui na escola, ainda acontece. E o PROMI não tenho certeza se tem ainda porque eu não estou frequentando... Mas sempre os projetos do PROMI, de extensão, estão sendo voltados para isso, para a cultura negra. As danças de cultura negra, sempre estão resgatando essa cultura.

Os alunos relatam, ainda, que poucos são os professores que trabalham com questões que envolvem as relações étnico-raciais em sala de aula e que as discussões se estabelecem de maneira frequente, mas pontual, não sendo reflexo do conteúdo e sim de questionamentos ou situações cotidianas.

Pesquisadora: E com relação ao conteúdo em sala de aula, vocês observam que a maioria dos professores estão aderindo ou não? Quero saber a opinião de vocês. Dudu: Já em relação a isso eu não me incomodo, não. Vamos dizer assim... Eu tenho uma língua solta com relação a isso. Assim, em relação aos professores, não. Eles não abordam a cultura negra, nós temos uma professora...

Oré: A redação aborda...

Dudu: A redação aborda? Ah, houve um comentário sobre "a cor do trabalho" feito pela Universidade Estadual da Bahia a UNEP...

Oré: A de redação e a de Português também...

Durante as entrevistas, os sujeitos participantes (alunos, gestoras e professora) apontam o preconceito com relação às religiões de matrizes africanas como um dos principais entraves à proposta de educação quilombola e à inserção das culturas africana e afro-brasileira nesse espaço escolar. Manuela expõe que esse preconceito se evidenciou na resistência, por parte de alunos e pais, em aceitar o novo contexto que se iniciava na escola, o que culminou na recusa em praticar capoeira, se alimentar da comida feita no ambiente escolar e, em alguns casos, na saída de alunos da escola:

Manuela: [...]Aceitação do Candomblé, outra grande resistência é o Candomblé. Inclusive, Maria, que é quem mais me auxilia nessa valorização do legado africano, ainda tem uma resistência fortíssima ao Candomblé. E eu passei aqui mais ou menos dois anos vestindo branco e usando as contas dos orixás, tanto que me chamavam de mãe de santo. Eu era católica. Isso era uma forma de mostrar para eles que não tinha 
nenhum problema. Podia, sem nenhum problema. E algumas vezes eu falava: "Eu sou do Candomblé". Até porque a minha família também tem uma raiz no Candomblé. E mostrava para tirar essa coisa da maldade, de que é do demônio, demoníaca. Mas que é da pessoa de bem, tão do bem quanto quem é católica, quanto protestante. Essa resistência ao Candomblé é o que mais dificulta a ação do reconhecimento em sua plenitude, eu acho que não chegamos ainda aos $100 \%$...Tanto que temos que pedir aos orixás que trabalhem por lá, no superior, para dar uma força (risos). Porque aqui não queriam fazer a nossa capoeira, não queriam merendar[...]

Pesquisadora: Os alunos?

Manuela: Os alunos, e as mães vinham para cá e diziam... Em um primeiro momento, quando a escola se autorreconheceu, quando começou a valorizar o negro, nós perdemos vários estudantes.

Segundo ela, essa resistência foi sendo vencida aos poucos com a postura da escola em afirmar seu compromisso com a valorização das culturas africana e afro-brasileira.

\begin{abstract}
Manuela: Protestante. Protestantes aqui destroem, me perdoem os protestantes, mas têm muitos que não conseguem aceitar a diversidade, destroem a cultura do outro [..] Pesquisadora: Esse predomínio é no bairro ou você percebe isso aqui também? Manuela: Predomínio também aqui na escola. Tanta que mães já chegam aqui falando assim: "Eu sou pastora viu professora". "Sim isso interfere em que?" Teve uma missionária, a menina filha dela inteligentíssima, inclusive ela fez parte até do fórum educação quilombola, viajou junto comigo e a mãe queria me entregar a filha. Disse: "Olha fique com ela porque Deus me deu um recado que eu tenho que sair por aí em missões sem dinheiro". "Eu não posso ficar com a sua filha, isso é inconstitucional. Você vai então tirar ela da escola. Ela não vai concluir o ensino médio se você tirar ela da escola". Então, essas pessoas daqui ainda recebem muito... Deus conversa muito com as pessoas daqui, elas recebem muitos recados, muitas revelações [...] Pesquisadora: Tem aluno aqui que é do Candomblé?

Manuela: Tem sim. Nós temos aqui uma professora que é do Candomblé, temos uma funcionária e temos Gabriel.

Pesquisadora: Gabriel é estudante?

Manuela: É estudante. E Muraguili, que é nossa funcionária, foi nossa aluna o ano passado. Eles não discriminavam muito, mas é aquela discriminação velada entre eles, sabe? ... "Deus é mais", não pode falar sobre o assunto. A educação quilombola tem uma aproximação com o Candomblé. Se a escola aqui não fosse assim tão rígida, como eles mesmo falam que é quase uma escola militar, a cultura afro não estaria tão valorizada. Tivemos que ser rígidas para ter o nosso reconhecimento. Então, os amigos entre si eles não discriminam de uma forma que todos possam perceber, eles discriminam quando estão mais afastados, de forma velada...
\end{abstract}

Como sabemos, a escola não é a única que exerce influência na formação dos sujeitos: o que é apreendido nas igrejas interfere em seu modo de pensar e, consequentemente, no modo como lidam quando o assunto é cultura ou religiões de matriz africana e afro-brasileira:

Os jovens que chegam à escola são resultado de um processo educativo amplo, que ocorre no cotidiano das relações sociais, quando os sujeitos fazem-se uns aos outros, com os elementos culturais a que têm acesso, num diálogo constante com os elementos e com as estruturas sociais onde se inserem e suas contradições. Os educandos podem personificar diferentes grupos sociais, ou seja, pertencem a grupos de indivíduos que compartilham de uma mesma definição de realidade, e interpretam de forma peculiar os diferentes equipamentos simbólicos da sociedade. (DAYRRELL, 2006, p. 142).

Muitas vezes, as interpretações aprendidas sobre as religiões de matriz africana são reflexo da internalização de preconceitos e estereótipos advindos de discursos fundamentalistas 
de algumas lideranças de igrejas pentecostais que, por meio do proselitismo religioso, agem de forma a estigmatizar e levar seus adeptos ao não respeito a religiões diferentes da sua. $\mathrm{O}$ efeito do proselitismo religioso é sentido na escola e se apresenta como um grande desafio no contexto escolar, que se coloca como parte na luta pela ressignificação do "ser negro" e "ser quilombola".

Tal efeito é extremamente prejudicial ao auto-reconhecimento da identidade negra e quilombola, uma vez relaciona marcadores importantes para a construção dessa identidade a aspectos negativos. Conforme disse Manuela, quando se trata de educação quilombola, de alguma forma, o diálogo com as religiões afro-brasileiras tem que ocorrer. Isso, não apenas pelo combate ao preconceito e pela valorização e reconhecimento de uma religião presente na comunidade quilombola de Barro Preto, mas porque é preciso haver uma compreensão histórica sobre a contribuição das religiões de matriz africana na luta e resistência de negros e quilombolas no contexto brasileiro, em especial na Bahia.

A relação entre quilombo e candomblé no contexto baiano é discutida pelo professor Ubiratan Castro de Araújo (informação verbal), em palestra concedida ao Bando de Teatro Olodum, em que expôs suas considerações sobre quilombos urbanos. O autor ressalta que fazia parte da Fundação Cultural Palmares no momento em que emergia a discussão em torno do conceito de quilombo urbano, a partir de casos emblemáticos, como o caso do quilombo dos Amarus (Minas Gerais), da Família Silva (Rio Grande do Sul) e Sacopam (Rio de Janeiro).

Nesse contexto, destacava-se o interesse e a preocupação em se investigar a existência de quilombos urbanos na cidade de Salvador ${ }^{110}$. Segundo o autor, foi possível constatar uma continuidade e superposição histórica entre quilombo e religiões de matriz africana, principalmente o Candomblé:

\footnotetext{
Quilombo urbano em Salvador são os terreiros e as casas-de-santo. As casas-de-santo são os verdadeiros quilombos da cidade de Salvador. Até porque se a gente olha para trás, havia uma continuidade [...], uma superposição de quilombo e Candomblé. Ou quilombo e cultos até anteriores ao Candomblé, como o calundu, como os assentamentos de santo. (ARAÚJO, 2014, informação verbal, transcrição nossa).
}

\footnotetext{
${ }^{110}$ Segundo Ubiratan, o estudo da história de Salvador permite dizer que quilombos urbanos e candomblés constituíram um tecido urbano na cidade de Salvador. Concentravam-se em áreas mais centrais e, aos poucos, com o crescimento urbano, foram sendo expulsos para áreas periféricas. "Esses quilombos urbanos passaram a ser quilombos de periferia e eles estão na raiz dos bairros populares [...] esses bairros que depois foram alcançados pelo tecido urbano, que antigamente eram perfeitamente plausíveis de serem candomblés de quilombos. Corta braço, Pero Vaz, na Liberdade [...] Constatação os quilombos e candomblés constituíram um tecido urbano de Salvador. Mas um tecido urbano marcado pela desigualdade, pela expulsão e segregação dos lugares". Informação verbal (transcrição nossa) fornecida por ARAUJO em Palestra concedida ao Bando de Teatro Olodum em evento realizado no Teatro Vila Velha, Salvador (BA). Publicada em 28 de abril de 2014. Fonte: Biblioteca Virtual 2 de Julho Disponível em: < https://youtu.be/U4B_NHkx3kU >. Acesso em: 10 de outubro de 2017.
} 
Ubiratan explica que não há uma tratativa do candomblé como quilombo urbano, mas a partir da compreensão de que ele se constitui de comunidades negras de origem religiosa que se mantêm unidas em um território em torno da tradição e da identidade, foi possível seu reconhecimento como patrimônio cultural afro-brasileiro ${ }^{111}$. Em nível municipal, a cidade de Salvador conta, hoje, com aparatos jurídicos ${ }^{112}$ de reconhecimento e proteção aos terreiros de candomblé como patrimônio histórico e cultural do município. Conforme salienta o professor Ubiratan:

Então do ponto de vista administrativo e político hoje a gente pode afirmar que o tratamento aos terreiros ele é análogo, ele é solidário ao tratamento dos quilombos. Entendido como uma comunidade negra com ancestralidade demonstrada africana e que é resistente às pressões externas, resistentes até à intolerância religiosa. Então esse caráter de resistência que marca um quilombo, o candomblé tem. E foi uma a forma específica da Bahia. (ARAÚJO, 2014, informação verbal, transcrição nossa).

O efeito do preconceito e da discriminação contra as religiões afro-brasileiras na escola é percebido e evidenciado pelos entrevistados, quando da resistência de alunos em falar sobre o assunto e da recusa de professores, sobretudo evangélicos, em realizar projetos relacionados à temática das relações étnico-raciais ou em inserir em sua aula discussão sobre história e culturas africana e afro-brasileira.

No trecho a seguir, os alunos expõem suas percepções sobre o tratamento dado às religiões afro-brasileiras no ambiente escolar:

Pesquisadora: Como vocês observam o tratamento da religião africana aqui dentro da escola?

Dudu: Ainda marginalizada.

Oré: Ainda é.

Dudu: Embora nós estejamos imbuídos nesse contexto de identidade africana, cultura africana e tudo mais, ainda há um preconceito muito grande em relação a isso. A maioria das pessoas não aceitam.

Pesquisadora: Por parte de....

Dudu: ...dos alunos

Odará: E de alguns professores também.

Oré: Dos professores também...

Dudu: Certos professores ainda marginalizam.

Oré: Criticam, falam mal...Tem um preconceito muito grande.

Dudu: Ainda arma aquela coisinha de nós contra eles. Ainda há essa ideia pairando no ar "Nós contra eles". Nós, de religiões advindas da Europa, contra religiões advindas da África. Fica aquela coisinha assim...Volta e meia sai uma faisquinha de

\footnotetext{
111 A Fundação Palmares é quem fornece aos terreiros de Candomblé o certificado de patrimônio cultural afrobrasileiro.

${ }^{112}$ Zambuzzi (2010) aponta a Lei $\mathrm{n}^{\circ} 7.216$, de 29 de janeiro de 2007 como mais recentemente criada pela prefeitura de Salvador, com intuito de preservar e proteger a cultura negra, reconhecendo-a como patrimônio histórico e cultural do município. A autora menciona, ainda, o Decreto ${ }^{\circ} 17.917$, de 12 de novembro de 2007, através do qual foi elaborado o cadastro Geral das Comunidades Religiosas da Cultura Afro-brasileira da cidade de Salvador. Em sua pesquisa, a autora faz referência a leis nas esferas federal, estadual e municipal, da cidade de Salvador, que possibilitaram, ao longo do tempo, o tombamento e reconhecimento de terreiros de candomblé como patrimônios culturais material e imaterial da cidade.
} 
fogo, "nós contra eles". Mas, como eu te falei, esse processo de desconstruir... Como é que eu vou desconstruir quinhentos anos de história que foi impregnado, "Oh brasileiro você é obrigado a digerir isso". Você vai digerir a cultura branca, você vai absorver a cultura branca, você vai ser branco, mesmo não sendo branco você vai ser branco e acabou. Você vai absorver essa cultura branca... Então, esse processo de desconstruir quinhentos anos de história, quinhentos anos de opressão, não é fácil. Não vai ser nem nesse ano e nem no ano que vem, vai ser um processo que vai se desconstruir ao longo da história. Quem sabe daqui há dez, vinte anos esta coisa, sabe?... Já vem sendo desconstruída bastante. Porque como a gente vê no Brasil... não só no Brasil no mundo todo, mas ainda mais no Brasil, que é uma sociedade muito preconceituosa ainda, muitos tabus sendo quebrados. Eles acabam abrindo espaço, a sociedade acaba aderindo. Ela começou a se expandir, começou a aderir aquelas pessoas mais marginalizadas, como é o caso, por exemplo, do Candomblé. Porque até pouco tempo atrás era um tabu. Ninguém tocava no Candomblé "Ah! Candomblé é coisa do Diabo", ninguém falava do Candomblé...Vou dar um exemplo aqui: "Ah, fulano é do Candomblé, não fica andando com ele não". Então, isso já vem sendo desconstruído já. Começou a ser aberto o espaço. Como aqui na escola, por exemplo, eu nunca me incomodei de ter um professor, ou um colega que seja, dessa religião. Eu sempre prego o respeito.

Pesquisadora: Você é de religião africana?

Dudu: Não. Eu sou evangélico.

Pesquisadora: E vocês?

Oré: Evangélico.

Odara: Tem a nossa colega...

Pesquisadora: Muraguili vem ensinar a gente um pouquinho.

Muraguili: $O$ ano passado, quando eu era aluna, foi na época que eu fiz santo, entendeu? Aí eu vim de cabeça raspada, vim de turbante, vim de contas. E o pessoal me aceitou, entendeu? Ninguém agiu de outra forma, ninguém da escola ficou tipo "Ah vou me afastar, olha a cabeça dela, como ela está vestida". Eu acho que a temática da escola, entendeu? A escola prega muito isso, ensina isso, mostra que a religião não é isso que todo mundo pensa. Mostra que é uma cultura de negros. Você vê um certo preconceito de alunos novos, que chegam novos na escola. Não é isso?

Muraguili: Você vê um certo preconceito, mas depois eles vão se adaptando à escola. Muitos alunos quando chegam: "Nossa essa escola é de gente macumbeira, olha aquilo ali cheio de vasos, cheio de coisas", mas quando passa e eles vem para a escola eles veem que não é nada daquilo. Eles aprendem sobre a cultura africana e vão deixando o preconceito meio que de lado. Tem um pouquinho de preconceito, porque isso aí é de milênios já. Vem de família, vem de berço... Esse preconceito vem de berço, é cultural isso aí, a gente não pode tirar totalmente aquele preconceito... Mas eles vão se adaptando.

Pesquisadora: Você acha que isso pode ser desconstruído?

Muraguili: Pode ser desconstruído... se tiver mais escolas... Não precisa ser igual aqui, mas se falasse mais dos negros, mostrasse aos alunos a cultura e como é a religião, eu acho que eles não teriam esse preconceito todo.

Dudu: Também tem aquela lei que eu não sei o nome... que eu não gravo o nome. Como que é o número...?

Oré: Dez mil....

Dudu: Dez mil e alguma coisa...

Pesquisadora: 10.639/2003

Dudu: De educação de matrizes africanas? Eu não sou muito bom com os números, não admito.

Pesquisadora: A lei prega a obrigatoriedade do ensino da história e cultura afrobrasileira e africana. E tem uma quilombola também.

Dudu: Tem quilombola também?

Pesquisadora: Tem as diretrizes curriculares nacionais com relação às escolas quilombolas e aqui o Estado de vocês a Bahia é o primeiro Estado a formular as diretrizes curriculares estaduais.

Dudu: Era obrigação dele, né... fazer isso? Com uma população tão majoritariamente negra. Então, acho que era uma obrigação do Estado fazer isso. 
Muraguili: Sem contar que a Bahia é o berço dos negros, né? Porque a maior parte dos negros vieram da Bahia. Em Salvador mesmo...

A historicidade do racismo introduz uma norma comportamental de negação de tudo o que diz respeito à cultura e às histórias africana e afro-brasileira, abarcando as religiões; nesse sentido Cunha Junior alerta que (2009)' demonizar as religiões de matriz africana faz parte de uma das dimensões do racismo antinegro. Dudu associa o preconceito com relação à cultura e às religiões de matriz africana à internalização de padrões de embranquecimento e à imposição da identidade branca como norma. Há em nossa sociedade “[...] uma necessidade quase doentia de se demonstrar o domínio da matriz europeia, de se assujeitar a ela como garantia de aprovação. É a expectativa de êxito que foi instituída que nos leva a isso.” (CUTI, 2017, p. 209). Essa identidade normatizadora se faz atuante entre os indivíduos, hierarquizando outras identidades e as diferenças: "Normalizar significa atribuir a essa identidade todas as características positivas possíveis, em relação às quais as outras identidades só podem ser avaliadas de forma negativa." (SILVA, 2000, p. 83). Corresponder a essa norma é uma condição para se integrar socialmente, ser reconhecido entre os outros. A supremacia dessa identidade é inteiramente dependente da produção de outras identidades como abjetas.

A produção e manutenção do "ser negro" como abjeto é condição para a perpetuação de privilégios do grupo social portador da identidade hegemônica que, ao fazer uso das diferenças como forma de hierarquização entre os grupos sociais, induz à negativização. Sem a reprodução das diferenças como algo negativo ela não se sustentaria, por isso o reconhecimento da alteridade é algo que assombra a identidade branca, pois constitui uma ameaça à sua dominação e poder. A escola é um dos espaços utilizados pelo grupo hegemônico para garantir que essa identidade seja fixada, internalizada, reproduzida e desejada pelos sujeitos sociais. O currículo é via principal, determinando-se o que se deve aprender e sobre o que se deve dialogar, legitimase a dominação:

\footnotetext{
O currículo não é um elemento inocente e neutro de transmissão desinteressada do conhecimento social. O currículo está implicado em relações de poder, o currículo transmite visões sociais particulares e interessadas, o currículo produz identidades individuais e sociais particulares. O currículo não é um elemento transcendente e atemporal - ele tem uma história, vinculada a formas específicas e contingentes de organização da sociedade e da educação. (MOREIRA; SILVA 1994, p. 07-08).
}

A desconstrução dessa identidade hegemônica como norma não é algo que se fará rapidamente. Como enfatiza Dudu, esse processo de reconstrução demanda grande esforço e tempo, uma vez que sentidos de normalidade balizados em noções racistas estão cristalizados em forma de consenso e crença (CUTI, 2017). Afinal são séculos de negação e demonização 
do "ser negro" e das matrizes culturais e religiosas africanas e afro-brasileiras. Não é fácil desconstruir o que tomamos durante toda a vida como "verdades" absolutas, por isso é fundamental a resistência de sujeitos, como os professores e alunos, a um novo contexto que se abre à enunciação das diferenças e à afirmação de marcas do "ser negro". Entretanto, a certeza é de que essa desmitificação, como observa Muraguili, não poderá ocorrer sem a desconstrução de estereótipos negativos a respeito da população negra e a tudo que, de alguma forma, dialoga com suas matrizes históricas e culturais.

Em seu depoimento, ela relata não sentir represálias ou discriminação por parte de outros alunos, associando isso à postura e ao trabalho da escola na valorização da cultura negra e desconstrução de visões negativas sobre as religiões afro-brasileiras. Ao mesmo tempo, percebe o preconceito como latente, referindo-se a ele como algo internalizado e difícil de ser completamente destruído. A educanda também refere a um maior grau de preconceito quando novos alunos entram na escola, através da reação depararem com objetos (esculturas, pinturas) que tematizam elementos africanos e afro-brasileiros. Contudo, aos poucos lhes é possível dialogar com a proposta da escola, de maneira que vão se "adaptando", ressignificando a forma de olhar o contexto escolar e as diferenças.

Manuela, como veremos na seguinte fala, relata perceber uma discriminação velada, direcionada a Muraguili, por parte de alguns alunos que, em virtude dos laços de amizade, exercem uma "discriminação velada", que ocorre sem a presença da pessoa a quem se direciona. Muraguili percebe que sofre preconceito, mas é evidente que as dimensões sutis das atitudes racistas fazem com que ela as perceba de forma mais amena. Na etiqueta do racismo à brasileira, as atitudes de preconceito devem ser dissimuladas e este fato compromete a percepção de quem é vítima, possibilitando àquele que discrimina, negar sua atitude. O racismo permanece nas entrelinhas e, sob a forma do silêncio e da fantasmagoria, se faz presente e atuante.

Muraguili e Dudu ressaltam a responsabilidade do Estado de construir leis e políticas públicas voltadas à população negra, como a Lei n ${ }^{\circ}$ 10.639/2003, que afirma o reconhecimento das culturas do negro e do indígena em equidade à cultura europeia. É preciso reconhecer que uma educação realmente libertadora não se concretiza com um currículo eurocêntrico, homogeneizador de identidades: como combater essa lógica se não nos abrirmos à alteridade?

Nesse sentido, repensar o currículo e a prática educativa pressupõe a cada educador repensar a própria identidade, em diálogo constante com a alteridade, o que pressupõe, sobretudo, ver o outro. A recusa em dialogar com conteúdos relativos às culturas e às histórias 
africana e afro-brasileira é recusar o reconhecimento das diferentes alteridades presentes no universo escolar.

Entendemos que, para uma parte dos professores, ultrapassar a ideia de que dialogar com um saber diferente de sua concepção de mundo, fere sua religiosidade. No entanto, afirmamos que falar com respeito sobre religiões diferentes não implica em aderir a elas, ou em doutrinar e, além disso, é necessário, nesse processo descrito, respeitar a diversidade religiosa presente no ambiente escolar, no qual coexistem alunos e professores de diferentes religiões católicos, candomblistas, espíritas, evangélicos, etc.

Dialogar sobre a diversidade religiosa auxilia na desconstrução de preconceito e discriminações, pode evitar que alunos e professores adeptos a religiões de matriz africana sejam discriminados e sofram violência física ou simbólica, e que não tenham que segredar sua prática religiosa por vergonha ou medo, como no caso de Iara, professora da escola e tia de um dos alunos entrevistados:

Oré: Iara. Ela é até mesmo do Candomblé.

Dudu: Ela é do Candomblé. Eu estudei em outras escolas e eu percebo que, em outras escolas, quando um professor é dessa religião ou é adepto a isso ele, de certa forma, fica marginalizado.

Oré: Aqui dentro ela se sente assim. Ela ensina física que no caso é Exatas. Então, no caso ela sente um desconforto em falar sobre isso. Eu sei porque ela é minha tia e eu converso com ela. Então, ela sente um desconforto em falar sobre esse assunto em sala de aula, ela prefere não falar: "Ah eu sou do Candomblé". Até mesmo na minha sala ela não prefere, por causa dessa marginalização entre os alunos, de criticar, de dizer que ela é isso... Algo que ela realmente não é.

Tive a oportunidade de realizar uma entrevista com Iara. Durante a nossa conversa em nenhum momento ela disse ser adepta dessa religião, embora o assunto tenha surgido. Quando perguntei se procurava inserir em suas aulas as questões relativas às relações étnico-raciais, ela respondeu que era difícil inserir no conteúdo das disciplinas de física e matemática, mas que em conversas, eventualmente, era possível comentar algo sobre o assunto.

Iara: Dentro do conteúdo fica um pouco complicado, né? Dentro da física, matemática você está trabalhando de fato com a relações étnico-raciais, mas em conversas...Como eu posso dizer... extras a gente está sempre falando, comentando algo desse tipo, mas trabalhando dentro de um plano de ação, nunca trabalhei não.

O exemplo de Iara é importante porque demostra que, no ambiente escolar, o preconceito com relação às religiões de matriz africana e afro-brasileira atinge a todos; é possível que esse fato interfira em sua prática docente pelo receio de ser vista de modo pejorativo. 
Sabemos que não é tarefa fácil dialogar com a temática das religiões de matrizes africana e afro-brasileira, por se um assunto polêmico e complexo, que carece de conhecimento e aprofundamento, por isso a necessidade de uma formação para a trabalhar esta temática sem incorrer proselitismos, de formas superficial e folclórica, o que que pode reforçar, ao invés de desconstruí-los. De início, torna-se fundamental uma formação que habilite o professor a olhar para as instituições e sua prática educativa de forma crítica. É preciso reconhecer que no interior da escola existem conflitos e tensões, inclusive de cunho religioso não, sobre os quais o diálogo é importante para o processo de construção positiva das identidades dos diferentes sujeitos que nela circulam.

O relato dos entrevistados a respeito da posição de outros alunos com relação às religiões de matrizes africana e afro-brasileira em sala de aula sugere o quanto o assunto ainda é arenoso:

Pesquisadora: Voltando à questão da sala de aula... Os alunos trazem estas questões na sala de aula?

Oré: Não.

Muraguili: Não.

Odara: Pelo contrário, eles preferem que não tenha. Acho que... pelo menos na minha sala, a maioria, mesmo que não tenha nenhuma religião, abomina o Candomblé e as religiões de matrizes africanas, porque é aquilo que é construído: "Não, essa religião aí é religião de pessoas que fazem coisas ruins".

Pesquisadora: E com relação às africanidades, à cultura negra....

Odara: Não. Mas é porque para eles tudo está ligado a isso. Então, tudo que fala sobre a África, que fala sobre preto: "Não, vai vir Candomblé pelo meio e eu não quero".

Pesquisadora: E quando fala sobre a questão da escravidão, sobre a situação da população negra hoje?

Odara: A questão histórica aborda, mas a questão da cultura mesmo eles preferem não lembrar. Eles até reclamam quando aborda.

Dudu: Eles dizem: "Ah! Professora você vai falar disso de novo" e não sei o que...

Oré: "Ah já estou enjoado de falar disso".

Dudu: Lá no Presidente... na escola municipal, na época em que saiu a lei, ela aderiu à matéria que ia falar da cultura africana e tal... Era "Cultura Afro-brasileira", na quinta e na sexta série, quando começou a falar da Umbanda e da Quimbanda: "Ah, eu não quero falar disso mais não professor. O professor só fala de Diabo em sala de aula". Até hoje eu lembro. "O professor só fala de demônio". Mas porque isso estava internalizado. Então, porque na escola não se fala sobre isso? Na escola tem os padrões que ficaram da colonização: "Oh, aqui não se fala disso, não se fala daquilo e daquilo outro". "Não se pode falar disso não". Então, quando abriu espaço, quando começou a se falar sobre isso o povo começou: "Ah isso é Macumba", "Isso é do Diabo". Mas com o tempo isso vai se dissolvendo, vai se desfazendo. Aqui na escola mesmo eu observo que não tem muito isso, outras escolas é pior. Ainda mais se tem pessoas que vem assim de outras classes...Vamos dizer assim de classes mais avantajadas da cidade. Acho que tem um preconceito muito grande em relação a isso.

Odara revela que, independentemente de serem adeptos ou não de alguma religião, a maioria dos alunos de sua sala tende a rejeitar as religiões afro-brasileiras e aponta que o tratamento de questões relativas à África e ao negro são vistas com desconfiança pelos alunos, 
que associam essas questões às religiões afro-brasileiras. Sua nos remete às reflexões de D’Adesky (2003, p. 143), sobre a dupla denegação do qual o negro é vítima.

[...] A primeira é alicerçada na desvalorização racial, considerando-o fora dos padrões estéticos dominantes. [...] A segunda forma de denegação é baseada na desvalorização da história do negro e na negação de reconhecimento da igualdade de valor intrínseco entre a culturas africanas e ocidental. O negro é aqui negado no seu modo de vida, no valor da sua cultura de origem e na sua história. Nesse sentido, os negros que se ressentem dessa denegação são os membros dos terreiros de candomblé e de umbanda, que assumem sem restrições os usos e valores das religiões de origem africana, os militantes do Movimento Negro, que reivindicam o pleno reconhecimento perante o Estado da igualdade da cultura afro-brasileira, e por fim a população negra como um todo, induzida, por falta de meios e informações, a rejeitar, em parte ou no todo, a especificidades das suas origens culturais e históricas.

As representações negativas formuladas socialmente em torno do "ser negro" se constituem em linguagem e reverberam no cotidiano; a esse respeito, Santos e Cruz (2012) argumentam que a linguagem é racialmente determinada e que, portanto, ao entrar neste campo, os indivíduos se inserem, concomitantemente, em um universo racializado em que "[...] o mal é representado pelo negro (FANON, 2008, p. 160).

Silva (2011, p. 31) salienta que o preconceito, os estereótipos e julgamentos são objetos internalizados e utilizados para a construção da percepção social do negro, ao mesmo tempo, objetiva e subjetiva. Entretanto, a mesma não é estanque: a representação de algo pode ser modificada e reconstruída a partir de elementos acrescentados ao longo do processo de reconstrução e remodelagem de objetos. Nesse sentido, conforme a autora sublinha, a representação social é ativa, constantemente reconstrói e remodela os dados vindos do exterior:

[...] transformar as representações sociais significa transformar os processos de formação de conduta em relação ao outro representado, bem como as relaçães com esse outro, porque na medida em que essas representações não apresentarem objetos de recalque e inferiorização desse outro, a percepção inicial e o conceito resultante dessa percepção, em nossa consciência, terá grande aproximação com o real.

Na perspectiva da autora, as representações sociais têm um caráter dinâmico, não fixo e, portanto, podem ser modificadas, nesse sentido, toda linguagem produzida sobre o negro pode ser desconstruída e ressignificada, porque é construída e adquirida. A escola tem papel fundamental na desconstrução de representações negativas sobre negro, não apenas através de conteúdos que abordem verídica e positivamente a população negra, mas na problematização da linguagem, por meio da leitura crítica de materiais didáticos e, acima de tudo, na problematização do que é dito, do que é silenciado, do gesto, do olhar, do que é experienciado. A partir do diálogo se pode transformar representações e, consequentemente, posturas com relação ao que é representado negativamente. 
Por esta razão, a necessidade de abordar as religiões de matriz africana, problematizar o que é pronunciado ou silenciado em torno delas - a referência às mesmas como algo demoníaco que, com frequência surge na fala de alunos em sala de aula, está relacionada a uma linguagem ideologicamente orquestrada pelo racismo, no intuito de produzir nos sujeitos o medo de enegrecer.

O racismo procura desacreditar sobre os valores culturais, impor climas de desconfiança e medo em relação às religiões. Nestes termos o racismo afasta as pessoas das suas fontes de identidade [...] $\mathrm{Na}$ atualidade, a mentalidade racista transforma as vítimas do racismo nos seus próprios algozes. Fazendo com que os próprios afrodescendentes trabalhem na divulgação de mitos e ideais absurdas sobre as culturas africanas. (CUNHA JUNIOR, 2009, p. 102).

Essa mesma ideologia instaura o tabu do silêncio sobre essas religiões, justamente para que não haja o entendimento sobre elas, para que a formulação sobre elas permaneça como "É coisa do demônio e ponto, não se fala mais nisso". Dudu evidencia o tabu em torno da abordagem dessas religiões na escola e, ao mesmo tempo, observa que, ao se oportunizar o diálogo, torna-se possível desconstruir algumas visões e posições preconceituosas. Odara, por sua vez, refere que a recusa dos alunos se relaciona mais a falar sobre cultura do que sobre história negra, duas dimensões abarcadas quando se discute religiões de matrizes africanas.

Cunha Junior (2009, p. 98-99) enfatiza que as religiões como o Candomblé e a Umbanda fazem parte do patrimônio material e imaterial da formação do povo brasileiro, e que elas devem ser abordadas como integrantes de identidade e das consciências histórica e cultural. O autor elenca quatro razões principais para a abordagem dessas religiões na escola:

\begin{abstract}
a) As culturas de base africana fazem parte da cultura da humanidade e da cultura brasileira. As religiões compõem modo de vida que estão ligadas ao modo de ser africano e de seus descendentes e para compreende-las é necessário um conhecimento mínimo de fundo cultural sobre estas religiões[...]. b) [...] as religiões de base africana foram parte importante da identidade dos africanos e afrodescendentes e através delas formação de resistência contra a dominação eurocêntrica[...] c) Pela existência de grupos de praticantes das religiões de base africanas na sociedade brasileira estas religiões difundiram conhecimentos que se tornaram inerentes a formação social brasileira. Pelo reconhecimento da diversidade cultural criada pelas religiões de base africana na sociedade brasileira uma vez que elas introduziram variações da língua, dos ritmos e da organização social exemplos de fazer coletivo [...]. d) Como motivo de combate ao racismo às populações afrodescendentes e a cultura negra. $\mathrm{O}$ racismo abarca as culturas e religiões (CUNHA JUNIOR, 2009, p. 98-99).
\end{abstract}

A escola se vê frente a um grande desafio: promover o entendimento de que ser quilombola, ser negro, eventualmente ser adepto de religião de matriz africana são coisas positivas e, apesar de não estarem necessariamente vinculadas, em uma perspectiva singular (do indivíduo), estão colocadas na perspectiva plural (da comunidade). A identidade é construída, ressignificada, reelaborada, deformada, formada sobre múltiplas formas de 
identificações - assim é possível ser negro, sem ser quilombola ou de religiões de matriz africana, e ser quilombola e evangélico, entre outras associações possíveis no campo do jogo das identidades em que cada sujeito se posiciona de forma singular.

No trecho seguinte, os alunos falam sobre o papel da escola no auto-reconhecimento da comunidade enquanto quilombola e ressaltam a articulação entre a comunidade escolar e a comunidade de Barro Preto como ponto importante no processo de aprendizagem:

Pesquisadora: A escola tem algum papel nesse auto-reconhecimtento [como quilombola] ou não?

Dudu: Sim, a escola tem o papel de ressignificar a identidade cultural do indivíduo que habita aqui na região, porque quando ela traz a cultura, quando começa a abordar as raízes ela começa a trazer à tona tudo aquilo que foi escondido foi encoberto. Porque a comunidade aqui ela é muito tempo forçada a marginal na sociedade, né? ...De Jequié. Então, com o tempo ela foi resgatando as raízes, puxando, trazendo o que está lá no fundo do baú, cheio de poeira e trouxe para cá... Isso tem o papel de ressignificar a identidade cultural da comunidade isso com certeza pode acontecer. Tem acontecido de forma lenta, mas acho que isso é um processo lento mesmo, porque mudar uma concepção que vem de anos, desde quinhentos e trinta quando começou o processo de colonização no Brasil, os negros começaram a serem trazidos para cá houve aquela coisa da marginalização do negro e depois com o término da escravidão, com a República ainda havia isso. E ainda hoje acontece, mas se você reparar que a escravidão foi abolida há que? Há 132 anos... Mudou bastante, mas ainda a visão do quilombola... O povo fala assim: "Ah quilombola..." Muitos não querem ser reconhecidos como tal, porque marginalizam até mesmo os quilombolas da comunidade. Então, esse processo de ressignificar a identidade é um processo lento... É um processo lento. A escola está fazendo isso, está cumprindo com isso mas é um processo lento, não devido a escola, mas devido à comunidade que ainda resiste a certas coisas. Esses dias mesmo eu visitei uma igreja na comunidade eu passei e disse certa coisa em relação à escola... Eu sou evangélico, mas com certo tipo de visão eu não concordo, em relação...Fica aquela coisa de nós contra a eles...Tipo nós evangélicos contra as religiões de matrizes africanas eu não concordo com isso. Eu acho que tem que haver o respeito. Ao mesmo tempo que eu concorde com as questões do evangelho e tal... Mas tem que ser abordado com respeito. Ele abordava com uma visão preconceituosa com relação as religiões de matrizes africanas. Então, esse dogma a ser quebrado com relação a esse tipo de coisa... Quilombola, quilombola... Eles querem atrelar assim... o Candomblé a uma coisa ruim, entendeu? Então, é uma coisa que vai levar um certo tempo para ser desfeito, dissolvido... Mas a escola tem cumprido o papel, tanto que...

Oré: Tenta passar para os alunos...

Dudu: Isso. Ela tem passado para os alunos.

Oré: E ela tenta abordar também a questão da família, ela tenta trazer a família da gente muito aqui para dentro, para justamente mostrar isso que ele está falando, a ressiginificação da comunidade com a escola.

Pesquisadora: Você falou que a escola faz esse trabalho de buscar a comunidade. De que forma?

Oré: Sim... qualquer projeto ele é aberto totalmente para a comunidade. E a gente tem aqui muitos projetos, como AVE em que se aborda muito isso, essa questão da valorização do negro aqui no colégio, a valorização do quilombola. Então, no caso ela avisa que vai haver isso, essa apresentação e tenta trazer nossos pais, familiares e vizinhos para mostrar isso.

Dudu: Tem um projeto aqui na escola que se chama família Milton Santos, já para trazer aquela ideia de fraternidade que a escola está atrelada à família. A educação familiar e a educação formal, que é dada na escola, são intrínsecas, estão intrinsicamente ligadas. Então, ela tenta trazer a família para dentro da escola, porque de nada adianta fazer uma coisa aqui na escola e em casa ser dissolvida pela família... Então, ela tenta trazer quando tem reunião, quando tem projetos, está sempre cobrando 


\begin{abstract}
a presença dos pais aqui na escola. Até mesmo para os maiores de dezoito anos é cobrada a presença dos pais.

Pesquisadora: Vocês observam mudanças na família de vocês com coisas que vocês levam da escola?

Dudu: Sim.

Oré: Sim, até porque a minha avó é do Candomblé e no caso ela aborda muito isso... E eu sou evangélico. Por eu ter nascido e visto muito isso eu não tenho preconceito nenhum. Até então, eu acho a mesma coisa que o Dudu, que deveria ser literalmente aberto, nem se deveria discutir isso, porque é concepção de cada um...Cada um escolhe. Então, o caso da valorização, por isso eu vim justamente estudar aqui, por esse motivo, por esta abordagem e porque ficava também mais perto de casa. E minha avó ela gosta muito desse colégio por causa da valorização da própria religião dela e da identidade.
\end{abstract}

Reconhece-se, portanto, que a escola desempenha um papel importante na ressignificação da identidade cultural dos membros da comunidade, para que esses venham a se reconhecer como quilombolas, diante da evidência, referida por Dudu, de que esta identidade tem sido forjada dentro de uma ordem social desigual, que a traduz por estigmas. $\mathrm{O}$ aluno ressalta que a escola pode interferir positivamente no processo de ressignificação da identidade cultural dos membros da comunidade, na medida em que se empenha em resgatar elementos relacionados à história, cultura e à ancestralidade negra e quilombola. De seu ponto de vista, o conhecimento sobre história e cultura relativos à população negra e, mais especificamente, sobre sua comunidade, auxilia no questionamento das condições de vida da mesma nos dias atuais e na compreensão de sua situação de marginalização social no contexto da cidade de Jequié.

Ou seja, trata-se de pensar a identidade do quilombo a partir do seu lugar na cidade. Os relatos revelam não apenas a escola como espaço que influencia na identidade dos membros da comunidade, há outros espaços, como a Igreja e a família. Destaca-se que a ressignificação da identidade cultural esbarra no preconceito com relação ao "ser quilombola" que, na fala de Dudu, muitas vezes é intensificado por discursos religiosos que buscam desqualificar o que é ensinado na escola, ao fazerem alusões negativas ao "ser quilombola" e às religiões de matriz africana.

Oré e Dudu destacam que a escola tem se empenhado em tornar visíveis suas ações para a comunidade, com intuito de que seus membros saibam qual é a proposta da escola e que participem com ela na construção do conhecimento. Os alunos veem como importante a articulação entre os contextos escolar e familiar. Fica evidenciada, na fala de Dudu, a importância desse diálogo entre escola/família para a eficácia de uma educação que se proponha a participar da desconstrução de estereótipos e preconceitos. 
Os alunos sinalizam que a escola tem interferido positivamente na representação sobre "ser negro" e "ser quilombola". Exemplo disso é trazido por Oré, ao relatar que sua avó gosta da escola porque tem valorizado sua religião e identidade, o que evidencia que a escola tem interferido positivamente nos contextos familiares, ao contribuir para afirmação positiva de seus valores culturais, religiosos e, por conseguinte, de sua identidade. Dudu e Oré são evangélicos e são netos de avós adeptas do Candomblé, exemplos de que o conhecimento e informações sobre religiões afro-brasileiras levam ao respeito e reconhecimento dessas religiões, independentemente da religião da qual o indivíduo seja adepto. Logicamente, devemos considerar que, desde muito cedo, conviveram com essa religião através de pessoas com quem têm um vínculo afetivo. Mas ainda assim, são exemplos de que, ao saber o que de fato significam as religiões afro-brasileiras, não há justificativas para resistências.

Há, na perspectiva dos alunos, uma ação significativa da escola no que tange à construção e afirmação da identidade negra e quilombola na comunidade de Barro Preto. No entanto, é nítido que não atribuem esse papel unicamente à escola e se veem como responsáveis pela sua própria formação e construção de conhecimentos.

\footnotetext{
Pesquisadora: Vejo que, além do que podem construir na escola, vocês buscam informações. Isso é muito importante.

Odara: Eu acho que a escola impulsiona e a gente tem que buscar por fora. Porque é uma escola em geral não tem como trabalhar só a cultura negra. Porque não está formando só pessoas expert em cultura negra, está formando pessoas para entrar na universidade, para passar no vestibular. Então não tem como focar só nisso. Eu acho que a escola impulsiona e a gente tem que buscar mais de fora, porque não dá para trabalhar tudo aqui, é muita coisa.

Dudu: Exatamente.

Muraguili: Mas geralmente quando você não estuda... Que nem eu, já era da religião, mas eu não tinha essa coisa... esse empoderamento, essa aceitação de falar assim: "Eu sou negra". Eu não tinha essa cabeça, entendeu? Eu sabia o que era a minha religião, mas não entendia a fundo o que era a cultura afro-brasileira, entendeu? Eu não sabia o que era a África, o que acontecia. A escola, como Odara falou, ela impulsiona a gente, ela dá uma base, um alicerce para a gente ir construindo. Ela incentiva a gente a procurar mais e a entender mais.
}

A escola é vista como uma intermediadora e incentivadora e ressignificadora na construção do conhecimento relacionado às culturas e histórias africana e afro-brasileira. Ao sugerir que a escola the forneceu um "alicerce" para buscar conhecimentos que a auxiliaram no desenvolvimento de empoderamento e autoidentificacao como negra, Muraguili sinaliza que a valorização das culturas e histórias africana e afro-brasileira na escola tem interferido positivamente nas representações sobre "ser negro".

Na perspectiva de Manuela a respeito da escola quilombola, evidencia-se o sentimento de que falta um maior envolvimento da família com a mesma sobre a reivindicação da efetivação do currículo quilombola. No entanto, ela acredita que as transformações, ainda que 
lentas, estão acontecendo e que serão melhor percebidas em um futuro próximo. Acredita, também, que a interação entre os saberes formais e informais (relativos ao currículo quilombola), poderá ocorrer de forma mais sistematizada, particularmente na sala de aula, a partir do momento em que os alunos formados hoje pela escola se tornarem pais. De seu ponto de vista, eles terão uma maior consciência da importância da valorização das culturas e histórias africana, afro-brasileira e quilombola e passarão a reivindicar sua inserção na educação de seus filhos, caso ela não esteja acontecendo. Expõe que o desenvolvimento de um trabalho mais efetivo relacionado à proposta quilombola de educação poderá ocorrer também por meio de estudantes quilombolas, que foram formados pela escola, e agora cursam licenciaturas nas universidades. Acredita que esses professores nativos da comunidade serão mais proativos na implementação do currículo quilombola, nesse contexto escolar:

\footnotetext{
Pesquisadora: Para o ano que vem quais são suas expectativas com relação às diretrizes curriculares estaduais?

Manuela: Eu acho que vai melhorar. Eu preciso achar que sim, né? ... E olhando também o passado, melhora. Sabe por quê? Porque quando eu tenho o amparo legal... porque enquanto diretora... porque eu sou empoderada enquanto Manuela, enquanto diretora se eu não tiver uma lei eu não fico empoderada. Então, enquanto diretora eu falo: "Olha gente está aqui. Não sou eu quem estou pedindo, não é Manuela quem está pedindo não, é a diretora. Porque a diretora é exigida pela secretaria de educação". Às vezes essa exigência não existe muito, sabe? Mas eu faço. Se a visão da escola é essa mistura de saberes e a comunidade não percebe a escola lá fora. Porque a comunidade não cobra? Se quando ela colocou o filho dela aqui eu disse a ela que existiria essa troca de saberes.

Pesquisadora: Quando você acha que vai acontecer em sala de aula?

Manuela: Eu acho que daqui uns vinte anos. Porque daqui a vinte anos o meu aluno vai ser o pai da criança que vai estar aqui. Então, a família lá já conhece, já valoriza, e vê a necessidade de que se cumpra essas diretrizes para educação quilombola. Então, ele vai perceber que o filho não está tendo... que esta interação no currículo não está acontecendo na escola. Ele vai começar a pressionar. Acredito nessa formação. E também estou acreditando que... eu tenho aqui cinco estudantes fazendo licenciaturas, cinco quilombolas, elas vão retornar. Elas vão ser minhas professoras ou a diretora da escola. Então, ela vai implementar. Então, vai acontecer pela família que já vai estar formada e vai acontecer quando esse estudante voltar como profissional da escola.
}

Para Manuela, a escola tem uma função social essencial, que não é exclusivamente sua, mas que também lhe cabe: contribuir para a construção da identidade quilombola nesse quilombo urbano. Segundo a diretora, a problemática em torno do auto-reconhecimento da comunidade como quilombola trouxe dificuldade, a princípio, em conseguir apoio pedagógico do ODERE, principal grupo que apoia a escola hoje.

[...] a professora Laura, que é a coordenadora do ODERE, ela só veio a nós aceitar, de fato, agora. Ela batia na tecla que tinha que ter primeiro o autorreconhecimento, ela não reconhecia a gente porque a comunidade não se autorreconhecia. Aí, eu fui fazendo o trabalho e ela observou que é possível também de cima para baixo. [...] Ao invés da comunidade convencer a escola, a escola faz o convencimento da comunidade. Aí, ela veio a acreditar, porque houve mudanças marcantes, ocorreram 
mudanças que percebemos, que traços da comunidade podem ser vistos agora como traços positivos no autorreconhecimento. Aí, ela está nós dando esta força maior. No primeiro momento, ela não acreditava que teria possibilidade.

Ressaltamos, mais uma vez, que o auto-reconhecimento como quilombola é um processo, assim como a construção da identidade quilombola e a própria constituição da escola enquanto quilombola. Nesse contexto, a escola inicia com seus sujeitos um processo de desconstrução em que se entende que as concepções não devem ser interpretadas a partir de significações absolutas, mas a partir de significações múltiplas (KREUTZ, 1998). Um processo, como bem evidenciam os sujeitos da pesquisa, lento e trabalhoso, cheio de incertezas, de entraves, mas que está em curso.

A escola é vista por todos os entrevistados, unanimemente, como um símbolo que identifica a comunidade como território quilombola, enquanto fonte de resgate de sua cultura e espaço de produção simbólica. Nesse ponto, a fala de Pedro é bastante ilustrativa: "Tem o colégio Duque de Caxias que hoje é conhecido como Milton Santos que é a escola padrão, é uma escola centralizada no quilombola..." Ela se configura, nesse quilombo urbano, como um pequeno mocambo onde seus sujeitos tecem narrativas, a partir da abertura de um baú empoeirado, como diz Dudu, cheio de formações, informações, contradições que interferem no processo de construção das identidades, seja, ela negra ou quilombola, por possibilitar novas formas de identificação. Os dilemas e produções que advêm desse processo, ainda que enviesados pelo racismo, indicam resistência. Há de se ter um olhar atento para a percepção das pequenas mudanças, pois elas podem indicar um movimento ininterrupto:

Odara: Eu acho que a escola tem um papel importante porque eles desconstroem a gente, a gente desconstrói em casa e de casa desconstrói no bairro, que desconstrói na cidade. Eu acho que em comparação a antes já é um avanço considerável, mas ainda tem muita coisa para ser desconstruída.

É possível afirmar, portanto, que a escola figura como protagonista por se constituir a instituição pública por excelência dentro do quilombo, pelo número de pessoas que agrega e pelas gerações que ali se inserem quanto e, especialmente, por sua essência formativa de (des)construção. 


\section{CONSIDERAÇÕES FINAIS}

Analisar os sentidos de identidade quilombola produzidos pelos sujeitos que participaram da pesquisa, bem como discernir o papel da escola nessa construção, foram os eixos que nortearam esse trabalho.

O reconhecimento oficial de Barro Preto como território de quilombo constituiu uma conquista de importância inquestionável. Porém, não marcou apenas o término de um processo, mas o início de outro. A própria denominação de "remanescente de quilombo", para além do rótulo jurídico ou de fórmula legal, serviu como elemento catalizador do processo de construção da identidade para os moradores do antigo bairro de Barro Preto. Dessa forma, esse nome "quilombo", e essa expressão pouco usual "remanescente" desencadearam na escola e na comunidade uma intensa reflexão sobre o significado de "ser quilombola".

Antes de qualquer demora, o primeiro enunciado que vem à mente como resposta à pergunta "o que é ser quilombola" é o de que "ser quilombola é ser negro". Não por acaso, alguns moradores do quilombo, em determinada ocasião, chegaram à conclusão: "Acham que agora somos negros”.

Ora, "ser negro é..." Infelizmente, por efeito da lógica tecida durante séculos de opressão, as reticências são preenchidas por representações negativas. O conceito de "raça" surgiu de forma implícita, mas recorrente, nas entrevistas. A identidade quilombola não pôde ser problematizada exclusivamente em termos étnicos, foi preciso discuti-la também em termos raciais, diante da pluralidade de significados subjacentes na discussão sobre o corpo, sobre o que significa ser negro, etc. Tal discussão remeteu à problemática do racismo e das representações sobre "raça" subentendidas nos discursos dos moradores quando se referiam ao que é ser negro. Havia os que consideravam raça como algo real, efeito da transmissão genética de caracteres físicos, havia os que a consideravam um constructo relativamente arbitrário, e ainda outros que assumiam esse arbitrário social como instrumento de afirmação étnica e política. Assim, a dimensão racial acabou repercutindo na problematização da dimensão étnica. Uma vez que desenvolver uma etnicidade pressupõe uma construção coletiva, o ponto inicial dessa construção, em uma comunidade majoritariamente negra, é o questionamento e a desconstrução de ideologias que postulam a naturalização da hierarquia entre grupos humanos para assegurar privilégios materiais e simbólicos a uns em detrimento de outros.

Ora, nem todos os quilombolas apresentam as mesmas características fenotípicas. Assim, independente desse critério de pertença, a identidade dos moradores do quilombo foi buscada no passado, de outra forma não seria possível imaginar-se como remanescente de 
quilombo. O próprio termo "remanescente", com sua conotação quase mítica, liga a comunidade aos primeiros ocupantes do território. Deste modo os habitantes do quilombo foram levados a resgatar histórias de opressão então vividas, muitas delas condicionando situações ainda não superadas, mas também a elaborar narrativas sobre experiências, aprendizados e conquistas coletivas.

O fato de comunidades quilombolas, contemporaneamente, serem tratadas como grupos étnicos, ou entendidas como "novas etnias" (ALMEIDA, 2002), não exclui o diálogo e vínculo com sua ancestralidade. Concordamos com Oliveira Filho (1998, p. 64), que argumenta: “[...] o que seria próprio das identidades étnicas é que nelas a atualização histórica não anula o sentimento de referência à origem, mas até mesmo o reforça. É da resolução simbólica e coletiva dessa contradição que decorre a força política e emocional da etnicidade".

Entendemos que a ancestralidade, ocasionalmente, pode ter um caráter fictício e mitológico, isto é, ela necessariamente não tem como fundamento vínculos consanguíneos com antepassados, redes de parentesco ou permanência de gerações sucessivas numa mesma terra. No caso de Barro Preto, a ancestralidade é mencionada pelos moradores como algo que lhes assegura a condição de sujeitos de direito, na medida em que o reconhecimento legal do quilombo se fez em consequência do vínculo com o território. A ancestralidade aparece como algo que tem como base o território e a memória.

Outro ponto a considerar é que as falas aqui transcritas ressaltam o estigma social que recai sob o quilombo, sua marginalização e a forma pejorativa com que muitos habitantes da cidade de Jequié se referem à comunidade. Enquanto comunidade periférica urbana, Barro Preto é marcada pelos mesmos problemas sociais e econômicos que afetam as periferias das cidades brasileiras. Segundo Carril (2006b, p. 243), existe uma correlação histórica entre quilombo e periferia, observada na fala daqueles que habitam esses territórios onde "[...] revelam-se permanências reeditadas pelos processos sociais espaciais engendrados na contemporaneidade".

"Ser quilombola” é uma construção que abarca sentidos construídos em diálogo com outros sujeitos e grupos sociais. Esses sentidos demarcam fronteiras, que diferenciam o quilombo urbano de periferia de outras comunidades urbanas periféricas, e a identidade negra e quilombola de outras identidades. Os sentidos de "ser quilombola" evidenciados na fala dos sujeitos da pesquisa, sinalizam que esse processo de diferenciação se encontra em curso.

Território e ancestralidade aparecem como elementos importantes para definir a identidade quilombola; a paisagem, vestígios e monumentos (como o Abarracamento e Caixa 
d'água) servem para caracterizá-lo como quilombo e marcar seu vínculo com uma ancestralidade negra territorial. A memória foi sublinhada como suporte para resgatar a origem quilombola, a territorialidade, nas palavras de Dudu, é uma "trançazinha", confeccionada pelo entrelaçamento das lembranças ligadas à terra que ressaltam os traços históricos e culturais e que dotam o grupo de singularidade.

O processo identitário envolve, portanto, dinâmicas internas e externas ao grupo, reflexões sobre si, sobre sua representação social para outros grupos, sobre a forma com que se vê os outros grupos. É sobre a base territorial que o grupo vai repensar sua representação no contexto social da cidade, contrastando-se com outros grupos: “'quem somos nós?' - 'de onde viemos e aonde vamos?' - ‘qual é a nossa posição na sociedade?'; ‘quem são eles?' - 'de onde vieram e aonde vão? - 'qual é a posição deles na sociedade?"” (MUNANGA, 2004a, p. 14). Esse repensar conduz à produção de identidade e de território do ponto de vista afetivosimbólico e de resistência.

A escola representa, para os sujeitos, uma instituição que torna a história presente e reafirma esse território como quilombola. Para eles, sua função seria, entre outras, a de contribuir para criar meios de reflexão e de questionamento da comunidade sobre si mesma. Em outras palavras, a escola pode criar condições para a comunidade se reposicionar como atuante e dotada de poder.

Esse empoderamento, na fala dos sujeitos, diz respeito à ressignificação do corpo negro e ao resgate às matrizes culturais e históricas africanas e afro-brasileiras. Percebemos, neste caso, que há uma preocupação da escola em orientar suas ações para o desenvolvimento da autoestima de alunos negros e quilombolas, e para a qualificação dos saberes da comunidade, de modo que ela possa se reconhecer como tendo valores próprios. Dessa forma, a escola buscou se apropriar do legado africano e afro-brasileiro e incorpora-los como referência curricular.

A dificuldade e a complexidade desta tarefa foram enfatizadas, os sujeitos da pesquisa apontaram o racismo e a ideologia do branqueamento como os grandes obstáculos a superar. As religiões de matriz africana e afro-brasileira, por exemplo, surgem como um dos sentidos de identidade negra e quilombola. Ao mesmo tempo em que essas religiões afirmam a identidade quilombola, por conta da alta densidade simbólica e pela relação íntima com cultura e com a memória da população negra, elas atuam também como obstáculo, uma vez que muitas igrejas cristãs, ao demonizar entidades sagradas afro-brasileiras, ao tomar referências culturais como questões de fé, torna aqueles que frequentam os terreiros e, por extensão, aqueles que tentam 
compreender e valorizar seus rituais, símbolos e narrativas, alvos de incompreensões, de fanatismo e de violências várias.

Assim, segundo alguns entrevistados, há casos de alunos e professores que, em virtude de pertencerem a religiões evangélicas e neopentecostais, resistem em tratar de questões que envolvem a cultura africana e afro-brasileira. Todavia, conforme relato da diretora, a situação vivida na época da pesquisa constituía um avanço, pois no início das ações da escola parte dos alunos recusavam-se a partilhar das atividades que envolviam a cultura negra, o que incluía aspectos do currículo e do cotidiano escolar, como a prática da capoeira e a merenda oferecida pela escola. Esse preconceito, em especial contra as religiões africanas e afro-brasileiras, constituiu, assim, um dos desafios a ser superado pela escola para efetivação do currículo quilombola.

O corpo negro, finalmente, tornou-se um marcador importante, surgiu como um dos pontos centrais dos enunciados ligados à identidade negra e quilombola, sua afirmação reconhecida como ato político. Em outras palavras, o que os sujeitos de pesquisa evidenciam é que, quando se é negro e quilombola, a afirmação da identidade passa pela afirmação do corpo como atitude política, como novo posicionamento nas relações de poder. Nesse ponto, importante lembrarmos as análises de Hall (2000), segundo o qual as identidades são posições que o sujeito é levado a assumir, uma sutura realizada através da articulação entre discursos, práticas e processos sociais que constituem o cerne da subjetividade. Essa sutura pressupõe investimento e é alimentada pelo sentido de pertencimento. Daí a necessidade sentida pela escola de multiplicar representações e referências capazes de valorizar o corpo negro para que os alunos construam uma imagem positiva do que é ser negro e ser quilombola. A transformação da imagem do corpo marcada pelo racismo em imagem positiva faz parte do vir a ser, do tornarse quilombola.

Assim, enfatizamos a importância da escola e da organização política na desconstrução de ideologias engendradas pelo racismo. A construção de uma identidade positiva ganha verdade na ação coletiva. "A afirmação da identidade contribui para que a comunidade defina o seu futuro, desenvolva os seus projetos de vida no território e fortaleça a sua cultura. É a identidade que afirma quem somos, onde estamos e o que queremos, de forma a envolver as pessoas individualmente e o grupo enquanto coletivo". (SILVA, 2013, p. 21).

Os alunos e os membros da associação de moradores entrevistados reconhecem que a escola, mesmo diante de obstáculos, tem desempenhado papel importante na desconstrução de estereótipos, atuando no desenvolvimento de sentidos de pertencimento e de afirmação da 
identidade negra e quilombola. Contudo, têm consciência dos limites da ação da escola e da necessidade de que suas ações sejam compartilhadas por outras instituições de dentro e de fora da comunidade. Dentro desses contornos, as discussões e entrevistas realizadas permitiram perceber que efetivamente a escola tem contribuído para a produção de sentidos positivos sobre "ser negro" e "ser quilombola". O que pode ser observado na pessoa daqueles que são o centro do fazer escolar, os alunos, cujo grau de criticidade e de consciência sobre as relações étnicoraciais é patente. Eles estão a par de discussões emergentes sobre as problemáticas que envolvem essas relações, sinalizando que o contexto escolar tem servido de incentivo à busca de conhecimentos e ao aprofundamento do assunto.

Em seu percurso de tornar-se quilombola, a escola tem enfrentado desafios para a implementação do currículo condizente com a proposta da Educação Escolar Quilombola. Esses desafios se relacionam com vários fatores: à dificuldade ou falta de preparo do professor para tratar de questões relacionadas à história e cultura africana e afro-brasileira; à falta de recursos; à falta de apoio da esfera pública municipal, etc.

Contudo, entre recuos, avanços, fracassos e sucessos a escola tem sido referência nas identificações dos sujeitos que nela circulam e se configurado como um espaço de acolhimento de sujeitos que, diante do rótulo jurídico, se veem impelidos a pensar sobre o que é ser quilombola, o que é ser negro e o que é uma comunidade remanescente de quilombo. O fato de receber alunos de outras localidades da cidade enriquece e colabora para que se discuta e se defina, por contraste, a identidade quilombola; além disso, proporciona que a mesma seja problematizada e pensada por indivíduos de outros grupos sociais. Ressaltamos neste estudo que o movimento de construção identitária é dialógico: a relação entre "eu" e o "outro", ou entre "nós" e "eles", pressupondo sempre a diferença, implicando contraste com marcas diferenciais derivadas do outro. Como ressalta Silva (2000), a afirmação da identidade envolve sempre a marcação da diferença e a construção de fronteiras, entre quem pertence ou não, entre quem está dentro e quem está fora, entre quem sou e o que não sou.

Os sentidos evidenciados pelos sujeitos revelam que há produção de uma identidade quilombola em curso. Importante mencionar que centramos as discussões em torno de alguns sentidos do "ser quilombola" identificados como relevantes para os sujeitos - ancestralidade, corpo, ato político, religião, território e memória -mas outros sentidos se apresentam. Não sabemos quais critérios de pertença, quais sinais diacríticos serão escolhidos futuramente pelo grupo para diferenciar-se, para demarcar fronteiras, pois se trata de uma produção em aberto. 
O caminho é cheio de interrogações e a única certeza é que a ação comunitária é necessária para que os moradores da comunidade possam dialogar entre si e com outras comunidades, organizar-se, desenvolver, aprofundar e ampliar vínculos. Afinal, nas palavras de Carlos: "Ser quilombola é você se assumir e realmente buscar seus direitos que foram negados no passado e que hoje continuam sendo negados". 


\section{REFERÊNCIAS ${ }^{113}$}

ABA. Documentos do Grupo de Trabalho sobre as Comunidades Negras Rurais. In: Boletim Informativo NUER, n. 1, 1994. Disponível em: < http://webcache.googleusercontent.com/search?q=cache:EUO6mIDi_GoJ:www.abant.org.br/f ile\%3Fid\%3D548+\&cd=3\&hl=pt-BR\&ct=clnk\&gl=br $>$. Acesso em: 11 abr. 2013.

ALMEIDA, A. W. B de. Terras de preto, terras de santo, terras de índio: uso comum e conflito. HEBETTE, Jean (Org.). Na trilha dos grandes projetos. NEAD, 1989, p. 163.

ALMEIDA, A. W. B de. Quilombos: sematologia face a novas identidades. SMDDH; CCN. (Org.) Frechal Terra de Preto: Quilombo reconhecido como Reserva Extrativista. São Luís: 1996, p. 11-19.

ALMEIDA, A. W. B de. Os Quilombos e as Novas Etnias. In O’Dwyer, Eliana C. (Org) Quilombos: identidade étnica e territorialidade. Rio de Janeiro: Ed. FGV, 2002, p. 83-108.

ANDRADE, M. de P. De pretos, negros. Quilombos, e quilombolas: notas sobre a ação oficial junto a grupos classificados como remanescentes de quilombos. Boletim Rede Amazônia, ano 2, n.1, p. 37-43, 2003.

ANDRÉ, M. E. D. A. Estudo de Caso em Pesquisa e avaliação educacional. Brasília: Liber Livro Editora, 2005.

ARAÚJO, U. C. de. Palestra do Prof. sobre Quilombos Urbanos concedida ao Bando de Teatro Olodum em evento realizado no Teatro Vila Velha, Salvador (BA). Publicada em 28 de abril de 2014. Biblioteca Virtual 2 de Julho. Disponível em: < https://youtu.be/U4B_NHkx3kU >. Acesso em: 10 de outubro de 2017.

APPIAH, K. A. Identidade Racial e identificação Racial. Tradução de Gisele dos Santos Belmon. Griot - Revista de Filosofia, Amargosa, Bahia, v. 2, n.2, dez. 2010. Disponível em: https://www2.ufrb.edu.br/griot/edicoes-anteriores?id=17. Acesso em: 02/02/2017.

ARGUEDAS, A. G. Território e identidade quilombola: uma reflexão sobre a emergência de novos sujeitos sociais e políticos no Brasil. VII CONGRESSO BRASILEIRO DE GEÓGRAFOS. Anais do VII CBG. 2014. Disponível em: <http://www.cbg2014.agb.org.br/resources/anais/1/1404564825_ARQUIVO_Territorioeident idadequilombola,CBG.pdf> Acesso em: 17 nov. 2017.

ARRUTI, J. M. A Emergência dos Remanescentes: Notas para o Diálogo entre Indígenas e Quilombolas. MANA 3(2):7-38, 1997.

ARRUTI, J. M. Territórios Negros. "Propriedade ou território?”. Não paginado e não datado. Disponível em:

http://www.geografia.fflch.usp.br/graduacao/apoio/Apoio/Apoio_Valeria/flg0563/1s2011/Ter ritorios_Negros.PDF>. Acesso em: 03 dez. 2017.

${ }^{113}$ De acordo com a Associação Brasileira de Normas Técnicas (ABNT NBR 6023). 
ARRUTI, J. M. Direitos Étnicos no Brasil e na Colômbia: Notas Comparativas sobre Hibridização, Segmentação e Mobilização Política de Índios e Negros. Horizontes Antropológicos, Porto Alegre, ano 6, n. 14, p. 93-123, nov. 2000.

ARRUTI, J. M. Agenciamentos Políticos da "Mistura": Identificação Étnica. Agenciamentos Políticos da "Mistura": Identificação Étnica e Segmentação Negro-Indígena entre os Pankararú e os Xocó. Estudos Afro-Asiáticos, Ano 23, nº 2, 2001, pp. 215-254.

ARRUTI, J. M. Mocambo - Antropologia e História do Processo de Formação Quilombola. Bauru. São Paulo: EDUSC, 2006, 368 p.

ARRUTI, J. M. Conceitos, normas e números: uma introdução a Educação Escolar Quilombola. Revista Contemporânea de Educação, vol. 12, n. 23, jan/abr de 2017.

BARDIN, L. Análise de conteúdo. Tradução de Luís Antero Reto e Augusto Pinheiro. LisboaPortugal: Edições 70, 1995.

BARAÚNA, L. M. P. B. À flor da pele. In: CARONE, I.; BENTO, M. A. S. (Orgs.). Psicologia social do racismo: estudos da branquitude e branqueamento no Brasil. Vozes: Rio de Janeiro, 2007.

BARTH, F. Grupos étnicos e suas fronteiras. In: POUTIGNAT, P.; STREIFF-FENART, J. Teorias da etnicidade. São Paulo: Editora: UNESP, 1997. p. 187-227.

BARTOLOMÉ. Miguel A. As etnogêneses: velhos atores e novos papéis no cenário cultural e político. Revista Mana, v. 12, n. 1, p. 39-68, 2006.

BASTIDE, R. As religiões Africanas no Brasil: Contribuições de uma sociologia das interpretações de civilizações. Editora: Universidade de São Paulo, 1971.

BRASIL. Constituição da República Federativa do Brasil. Brasília: Senado, 1988.

BRASIL. Lei n 9.394, de 20 de dezembro de 1996. Estabelece as diretrizes e bases da educação nacional. Diário Oficial da União, Brasília, DF, 23 dez. 1996.

BRASIL. Decreto Presidência da República nº 3.912 de 10 de setembro de 2001.

BRASIL. Decreto Presidência da República nº 4.887 de 20 de novembro de 2003.

BRASIL. Lei 10.639, de 9 de janeiro de 2003. D.O.U de 10/01/2003.

BRASIL. Decreto Presidência da República nº 6.040 de 7 de fevereiro de 2007.

BRASIL, Conselho Nacional da Educação. Parecer CNE/CP 3/2004, de 10 de março de 2004a. Diretrizes Curriculares Nacionais para a Educação das Relações Étnico-Raciais e para o Ensino de História Cultura Afrobrasileira e Africana. Diário Oficial da União de 19/5/2004.

BRASIL. Diretrizes Curriculares para as relações étnico-raciais. Brasília, Distrito Federal. 2004b. Disponível em: < http://www.acaoeducativa.org.br/fdh/wp- 
content/uploads/2012/10/DCN-s-Educacao-das-Relacoes-Etnico-Raciais.pdf>. Acesso em: 17 de agost de 2017.

BRASIL. Ministério da Educação / Secretaria da Educação Continuada, Alfabetização e Diversidade. Orientações e Ações para Educação das Relações Étnico-Raciais Brasília: SECAD, 2006.

BRASIL. Conselho Federal de Educação (CNE). Resolução CEB nº 4, de 13 de julho de 2010a. Define Diretrizes Curriculares Nacionais Gerais para a educação básica. Diário Oficial da União, Brasília, DF, 14 jul. 2010. Seção 1, p. 824.

BRASIL. Conselho Nacional de Educação (CNE). PARECER CNE/CEB No: 7/2010b. Diretrizes Curriculares Nacionais Gerais para a Educação Básica, Brasília, DF, 9/7/2010, Seção 1, Pág.10. Disponível em: http://portal.mec.gov.br/index.php?option=com_docman\&view=download\&alias=5367pceb007-10\&Itemid=30192> Acesso em: 04 nov 2017.

BRASIL. Conselho Nacional de Educação. GOMES, Nilma, Lino (relatora). Texto - referência para a elaboração das Diretrizes Curriculares Nacionais para a Educação Escolar Quilombola. Brasília, 2011.

BRASIL. Parecer CNE/CEB, no 16/2012a - Diretrizes Curriculares Nacionais para a Educação Escolar Quilombola. Aprovado em: 5 jun. 2012. Disponível em: < http://etnicoracial.mec.gov.br/images/pdf/diretrizes_curric_educ_quilombola.pdf> Acesso: 00 de sete, 2017.

BRASIL. Conselho Nacional de Educação (CNE). Resolução CEB no 8, de 20 de novembro de 2012b. Define Diretrizes Curriculares Nacionais para a Educação Escolar Quilombola na educação básica. Diário Oficial da União, Brasília, DF, 21 nov. 2012. Seção 1, p. 26.

BRASIL. Plano Nacional de Implementação das Diretrizes Curriculares Nacionais para Educação das Relações Étnico-Raciais e para o Ensino de História e Cultura Afrobrasileira e Africana. Ministério da Educação, Secretaria de Educação Continuada, Alfabetização, Diversidade e Inclusão. Brasília: MEC, SECADI, 2013 a.

BRASIL. Diretrizes Curriculares Estaduais para a Educação Escolar Quilombola. Resolução CEE/CEB No 68/2013b.

BENTO, M. A. S. Branqueamento e Branquitude no Brasil. In: CARONE, I.; BENTO, M. A. S. (Orgs.). Psicologia social do racismo: estudos da branquitude e branqueamento no Brasil. Vozes: Rio de Janeiro, 2007.

BHABHA, H. K. O local da cultura. Tradução de Myriam Avila, Eliana Lourença de Lima Reis, Glaucia Renate Gonçalves. Belo Horizonte Editora: UFMG, 1998.

BRAH, A. Diferença, diversidade e diferenciação. Cadernos Pagu, Campinas, n. 26, jun. 2006. Disponível em: < http://www.scielo.br/pdf/cpa/n26/30396.pdf>. Acesso em: 21 dez. 2014. 
BRITO, A. E. C. de. Entre negro e branco: socialização de filhos mestiços por famílias interétnicas. In: OLIVEIRA, I. de; SILVA, P. B. G. e (Orgs.). Negro e educação: Identidade negra - pesquisas sobre o negro e a educação no Brasil. ANPED; Ação Educativa. 2003.

CAMPOS, A. Do quilombo à favela: A produção do "espaço criminalizado" no Rio de Janeiro. Bertrand Brasil: Rio de Janeiro, 2007.

CARDOSO, M. A. O movimento negro em Belo Horizonte: 1978-1998. Dissertação (Mestrado em História) - Universidade Federal de Minas Gerais, Belo Horinzonte, 2001. Disponível em: <http://livros01.livrosgratis.com.br/cp000210.pdf> Acesso em: 27 nov. 2017.

CARNEIRO DA CUNHA, M. Antropologia do Brasil - Mito, História e Etnicidade. São Paulo: Brasiliense: Editora da Universidade de São Paulo, 1986.

CARNEIRO DA CUNHA, M. In: CARVALHO, M. R. G. de (Org.). Mobilização Política e Cidadania. Salvador, OEA/UFBA/EGBA, 1989.

CARRIL, L. de F. B. Quilombo, território e geografia. In: Revista Agrária, no 3, pp. 156-171, São Paulo, 2006a. eletrônica: http://www.revistas.usp.br/agraria/article/download/92/91.

CARRIL, L. de F. B. Quilombo, favela e periferia: a longa busca da cidadania. São Paulo: Annablume; Fapesp, 2006b.

CHALHOUB, S. Medo branco de almas negras: Escravos, libertos e republicanos na cidade do Rio. O medo Revista Brasileira de história. São Paulo, v. 8, nº 16. Ma.1988/ago.1988, pp. 83-105.

CHALHOUB, S. Visões de Liberdade: uma história das últimas décadas da escravidão na corte. São Paulo: Companhia da Letras, 1990.

CASHMORE, E. Dicionário de relações étnicas e raciais. São Paulo: Selo Negro Edições, 2000.

CERQUEIRA, D. R. C.; MOURA, R. L. de. Nota Técnica: Vidas perdidas e racismo no Brasil. IPEA (Instituto de Pesquisa Econômica Aplicada) Brasília, 2013. Disponível em: < http://www.seppir.gov.br/central-de-conteudos/publicacoes/pub-pesquisas/nota-tecnica-vidasperdidas-e-racismo-no-brasil.pdf >. Acesso em: 15 nov. 2017.

CIAMPA, A. da C. Identidade. In: LANE, S. T. M.; CODO, W. (Orgs.) (Org.). Psicologia social: o homem em movimento. São Paulo: Brasiliense, 2001. p.58-75.

CONFERÊNCIA NACIONAL DE EDUCAÇÃO (CONAE). Documento final. Brasília: MEC, SEA, 2010. Disponível em: <

http://conae.mec.gov.br/images/stories/pdf/pdf/documetos/documento_final_sl.pdf $>$. Acesso: 09 set 2017.

COSTA, A. C. F. Educação, Turismo e Ação Griô: Impactos da modernidade na comunidade quilombola do Remanso (Lençóis-BA). Dissertação (Mestrado em História). Faculdade de Filosofia, Letras e Ciências Humanas. Universidade de São Paulo, 2015. 
COSTA, E. S. Racismo política pública e modos de subjetivação em um quilombo do Vale do Ribeira. Tese (Doutorado - Programa de Pós-graduação em Psicologia. Área de Concentração: Psicologia Social) - Instituto de Psicologia da Universidade de São Paulo. 2012.

COSTA, J. F. (Org.) Da cor ao corpo: a violência do racismo. Violência e psicanálise. $3^{\mathrm{a}}$. ed. Rio de Janeiro: Graal, 2003.

COSTA E SILVA, A. A manilha e o Libambo. A África e a escravidão de 1500 a 1700 . Rio Nova Fronteira, 2011.

CROCHIK, José Leon. Preconceito, indivíduo e sociedade. Temas psicologia, Ribeirão Preto, v. 4, $\mathrm{n}^{\circ} \quad 3, \quad$ p. 47-70, dez. 1996. Disponível em: $<$ http://pepsic.bvsalud.org/scielo.php?script=sci_arttext\&pid=S1413389X1996000300004\&lng=pt\&nrm=iso>. Acesso em: 22 abr. 2017.

CUNHA JUNIOR, H. Etnia Afrodescendente, Pluriculturalismo e Educação. Revista Pátio. Artes Médicas. Ago./out. 1998.

CUNHA JUNIOR, H. Candomblé: como abordar esta cultura na escola. Revista Espaço Acadêmico (UEM), v. 102, p. 97-103, 2009.

CUNHA JUNIOR, H. Afrodescendência e espaço urbano. In: CUNHA JUNIOR, H.; RAMOS, M. E. R. (Orgs). Espaço urbano e afrodescendência: estudos da espacialidade negra urbana para o debate das políticas públicas. Fortaleza: Edições UFC, 2007.

CUTI. Quem tem medo da palavra negro. In: KON, N. M.; ABUD, C. C.; SILVA, M. L. da (Orgs.). O racismo e o negro no Brasil: questões para a psicanalise. São Paulo: Perspectiva, 2017.

DAYRRELL, J. A escola como espaço sócio-cultural. In: DAYRREL, J. (Org.) Múltiplos olhares sobre Educação e Cultura. Editora: UFMG. Belo Horizonte, 1996.

Desenvolvimento Humano para Além das Médias. Brasília: PNUD: IPEA: FJP, 2017 Disponível em: < http://www.br.undp.org/content/dam/brazil/docs/IDH/desenvolvimentoalem-das-medias.pdf > Acesso em: 12 nov 2017.

DOMINGUES, P. Movimento Negro Brasileiro: alguns apontamentos históricos. Revista Tempo, v. 12, n. 23, p. 100-122, 2007. Acesso em 20 dez. 2016. Disponível em: < http://www.scielo.br/pdf/tem/v12n23/v12n23a07>.

ERIKSON, E. H. Identidade, juventude e crise. Rio de Janeiro: Editora Guanabara, 1968.

FANON, F. Pele negra, máscaras brancas. Tradução de Renato Silveira. Salvador: EDUFA, 2008.

FERNANDES, V. F. Educação e relações raciais: percepções de alunos e professores de uma escola pública de São Carlos. Dissertação (Mestrado em Educação Escolar). Universidade Estadual Paulista (UNESP), Araraquara, 2010. 
FERNANDES, F. S. O monumental e o íntimo: dimensões da memória da resistência no documentário brasileiro recente. Revista Estudos Históricos, Rio de Janeiro, v. 26, n. 51, p. 55-72, ago. 2013. Disponível em: <http://bibliotecadigital.fgv.br/ojs/index.php/reh/article/view/7195/9365>. Acesso em: 27 out. 2017.

FERREIRA-SANTOS, M. O Ancestral: entre o singular e o universal. 2012. Disponível em: $<$ https://edisciplinas.usp.br/pluginfile.php/345975/mod_forum/intro/ancestral_singular_univer sal.pdf >. Acesso em: 16 maio 2017.

FERREIRA-SANTOS, M. Ancestralidade e convivência no processo identitário: a dor do espinho e a arte da paixão entre Karabá e Kiriku. Educação anti-racista: caminhos abertos pela Lei Federal $n^{\circ}$ 10.639/2003. Secretaria de Educação Continuada, Alfabetização e Diversidade. Brasília: Ministério da Educação, 2005. (Coleção Educação para todos).

FUNARI, P. P. de A. A arqueologia de Palmares. Sua contribuição para o conhecimento da história da cultura afro-brasileira. In: REIS, J. J.; GOMES, F. dos S. (Orgs.). Liberdade por um Fio: História dos quilombos no Brasil. São Paulo: Companhia da Letras, 1996, p. 26-51.

FCP - FUNDAÇÃO CULTURAL PALMARES. Quadro geral de comunidades remanescentes de quilombos (CRQs). Disponível em: http://www.palmares.gov.br/file/2017/09/QUADRO-DE-COMPARATIVO-DECERTIFICA\%C3\%87\%C3\%95ES-ANUAIS-09-2017.pdf

FURTADO, M. B.; PEDROZA, R. L. S.; ALVES, C. B. Cultura, identidade e subjetividade quilombola: uma leitura a partir da psicologia cultural. Psicologia \& Sociedade, Belo Horizonte, v. 26, n. 1, p. 106-115, 2014. Disponível em:

GILROY, P. Entre campos: nações, cultura e o fascínio da raça. Tradução de Célia Maria Marinho de Azevedo et al. São Paulo: Annablume, 2007.

GATTI, B. A. Grupo focal na pesquisa em ciências sociais e humanas. Brasília: Líber Livro, 2005.

GLASS, Ronald. Entendendo raça e racismo: por uma educação racialmente crítica e antirracista. Revista Brasileira Estudos Pedagógicos, v.93, n. 235, p. 235, p. 883-913, set/dez. 2012.

GOFFMAN, E. Estigma: notas sobre a manipulação da identidade deteriorada. Rio de Janeiro: Zahar, 1978.

GOFFMAN, E. A representação do eu na vida cotidiana. Petrópolis: Vozes, 1985.

GOMES, F. dos S. Mocambos e quilombos: uma história do campesinato negro no Brasil. São Paulo: Claro Enigma, 2015. (Coleção Agenda Brasileira).

GOMES, N. L. Corpo e cabelo como símbolos da identidade negra. 2006. Disponível: < $<$ http://www.acaoeducativa.org.br/fdh/wp-content/uploads/2012/10/Corpo-e-cabelo-comos\%C3\%ADmbolos-da-identidade-negra.pdf $>$. Acesso em: 27 nov. 2017. 
GOMES, N. L. Salões étnicos como espaços estéticos e políticos de identidade negra. In: GROSSI, M. P. et al. (Orgs.) Movimentos sociais, educação e sexualidades. Rio de Janeiro: Editora Garamond, 2002.

GOMES, N. L. A contribuição dos negros para a pensamento educacional brasileiro. In: SILVA, P. B. G. e.; BARBOSA, L. M. de A. (Orgs). Pensamento negro em educação no Brasil: expressões do movimento negro/ São Carlos: Ed. Da UFSCar, 1997.

GOMES, N. L. Educação, identidade negra e formação de professores/as: um olhar sobre o corpo negro e o cabelo crespo. Educação e Pesquisa, São Paulo, v.29, n.1, p. 167-182, jan./jun. 2003.

GOMES, A. M. da S. Etnobotânica e territorialidades negras urbanas da Grande Belo Horizonte: Terreiros e quintais. In: SANTOS, R. E. dos S. (Org.). Questões urbanas e racismo. Petrópolis, RJ: DP et Alii Brasília, DF : ABPN, 2012.

GONÇALVES FILHO, J. M. A dominação racista: o passado e o presente. In: KON, N. M.; SILVA, M. L. da; ABUD, C. C. (Orgs.). O racismo e o negro no Brasil: questões para a psicanalise. Editora: Perspectivas, São Paulo, 2017.

GUILLEN, I. C. M. Ancestralidade e oralidade nos movimentos negros de Pernambuco. Africa's , v. 3, p. 174-207, 2016.

GUIMARÃES, A. S. A.; HUNTLEY, L. (Orgs.). Tirando a máscara: ensaios sobre racismo no Brasil. São Paulo: Paz e Terra, 2000.

GUImARÃES, A. S. A. Classes, raças e democracia. São Paulo: Fundação de apoio à Universidade de São Paulo: Ed. 34, 2002.

GUIMARÃES, A. S. A. Preconceito racial: modos, temas e tempos. São Paulo: Cortez, 2008.

GUSMÃO, N. M. M. de. Da antropologia e do direito: impasses da questão negra no campo. Palmares em Revista, Brasília: Fundação cultural Palmares, n.1, p. 1-13, 1996.

GUSMÃO, N. M. M. Da antropologia e do direito: impasses da questão negra no campo. Fundação Cultural Palmares. Brasília, 1999.

GUSMÃO, N. M. M. Terras de uso comum: oralidade e escrita em confronto. Afro-Ásia, n. 16, $1995 . \quad$ Disponível em: <https://portalseer.ufba.br/index.php/afroasia/article/view/20850/13450> Acesso em: 24 mar. 2017.

HAERTER, L. A categoria "território" como elemento de autoadscrição étnica. Revista eletrônica do grupo de pesquisa identidade! da Escola Superior de Teologia (Faculdades EST). São Leopoldo: Rio grande do Sul. V. 17, N. 1, jan-jun, 2012. Disponível em: http://periodicos.est.edu.br/index.php/identidade/article/view/317/382 Acesso em: 10 de março de 2017.

HALBWACHS, M. A Memória Coletiva. São Paulo: Vértice, 1990. 
HALL, S. Identidade cultural e diáspora. In: Revista do Patrimônio Histórico e Artístico Nacional. Rio de Janeiro, IPHAN, 1996, p. 68-75.

HALL, S. Quem precisa de identidade? In: SILVA, T. T. da (Org.). Identidade e diferença: a perspectiva dos estudos culturais. Petrópolis: Vozes, 2000. p. 103-133.

HALL, S. Da diáspora: Identidade e mediações culturais. Tradução de Adelaine La Guardiã Resende. Belo Horizonte: UFMG; Brasília: Representação da UNESCO no Brasil, 2003.

HALL, S. A identidade cultural na pós-modernidade. Rio de Janeiro: DP\&A, 2006.

HIRANO, L. F. K. O olhar oposicional e a forma segregada: raça, gênero, sexualidade e corpo na cinematografia hollywoodiana e brasileira (1930-1950). ACENO, Vol. 2, N. 3, p. 142-158. Jan. a Jul. de 2015. ISSN: 2358-5587.

HIRANO, L. F. K. O imaginário da branquitude à luz da trajetória de grande otelo: raça, persona e estereótipo em sua perfomance artística. Afro-Ásia [online]. 2013, n.48, pp. 77-125. Disponível em: < http://www.scielo.br/scielo.php?script=sci_arttext\&pid=S000205912013000200003 > Acesso em: 06 nov 2017.

INCRA. (Ministério do Desenvolvimento Agrário Instituto Nacional de Colonização e Reforma Agrária). Regularização de território quilombola: Perguntas e respostas. Diretoria de ordenamento da estrutura fundiária coordenação geral de regularização de territórios quilombolas - DFQ. Disponível em: <http://www.incra.gov.br/sites/default/files/incraperguntasrespostas-a4.pdf>. Não datado. Acesso em: 23 março de 2017.

INEP - Instituto Nacional de Estudos e Pesquisas Educacionais. Anísio Teixeira. Censo escolar da educação básica, 2016. Notas Estatísticas. Disponível em: http://download.inep.gov.br/educacao_basica/censo_escolar/notas_estatisticas/2017/notas_est atisticas_censo_escolar_da_educacao_basica_2016.pdf Acesso em: 11 set 2017.

KREUTZ, L. Identidade étnica e processo escolar. Cadernos de Pesquisa (Fundação Carlos Chagas), São Paulo, n.107, p. 79-97, 1999.

LEITE, I. B. Os Quilombos no Brasil: questões conceituais e normativas. Etnográfica. Vol. IV (2), p. 333-354, 2000.

LEITE, I. B. Remanescentes das comunidades dos quilombos: Memórias do Cativeiro e políticas e reparação no Brasil. REVISTA USP, São Paulo, n.68, p. 104-111, dezembro/fevereiro 2005-2006.

LEITE, I. B. O Projeto Político Quilombola: Desafios, Conquistas e Impasses Atuais. Estudos Feministas, Florianópolis, 16(3): 965-977, setembro-dezembro/2008.

LEITE, I. B. Repertórios culturais, identidades étnicas e educação em território de maioria afrodescendente. In: OLIVEIRA, I.; SILVA, P. B. G. e (Orgs.) Identidade negra: pesquisas sobre o negro e educação. 2003. Disponível em: http://www.acaoeducativa.org.br/relacoesraciais/wpcontent/uploads/2013/12/Negro-Educacao-2-INEP.pdf

LIMA, I. M. de F. Maracatus-Nação. Ressignificando velhas histórias. Recife: Bagaço, 2005. 
LIMA, M. B. Identidade étnico-racial no Brasil: Uma reflexão metodológica. Ano 2, volume 3 - p. 33-46 - jan-jun de 2008.

LITTLE, P. E. Territórios Sociais e Povos Tradicionais no Brasil: por uma antropologia da territorialidade. Série Antropologia $N^{\circ}$ 322. Departamento de Antropologia/UnB. Brasília 2002.

LOURO, G. L. (Org) Pedagogias da sexualidade. In: LOURO, G. L. O corpo educado: Pedagogias da sexualidade. Belo Horizonte: Autêntica, 2000.

LOPES, A. Escola, socialização e cidadania: um estudo da criança negra numa escola pública de São Carlos. São Carlos, 1994. Dissertação (Mestrado em Educação) - Universidade Federal de São Carlos.

LÜDKE, M. e ANDRÉ, M. Pesquisa em educação: abordagens qualitativas. São Paulo: EPU, 1986.

LUZ, M. A. Cultura negra e a ideologia do recalque. Edições Achiamé Ltda. 1983.

MARINHO, T. A. A construção da subjetividade entre os kalunga do Vão do Moleque. RBSE 9(26): 629-688, Ago2010. Disponível em: < https://odonto.ufg.br/up/133/o/ThaisArt.pdf>. Acesso em: 02 dez. 2017.

MARTINS, G. A. Estudo de caso: uma estratégia de pesquisa. 2 ed. São Paulo: Atlas, 2008.

MATTOS, H. Memórias do cativeiro: narrativas e identidade negra no antigo Sudoeste cafeeiro. In: RIOS, A. M. L. e MATTOS, H. M. (Orgs.). Memórias do cativeiro: família, trabalho e cidadania no pós-abolição. Rio de Janeiro: Civilização Brasileira, 2005, p. 35-135.

MATTOS, H. "Remanescentes das comunidades dos quilombos": memória do cativeiro e políticas de reparação no Brasil. Revista USP, São Paulo, n.68, p. 104-111, dezembro/fevereiro 2005-2006.

MATTOS, H. Entrevista à Revista de História. Entrevistador: Marcello Scarrone. Data: 01/11/2008.Disponível em: <http://www.revistadehistoria.com.br/secao/entrevista/hebemattos>. Acesso em: 06 jan. 2013.

MELUCCI, A. A invenção do presente: movimentos sociais nas sociedades complexa. Petrópolis: Vozes. 2001.

MEMMI, A. Retrato do colonizador precedido pelo retrato do colonizado. Tradução de Ronald Corbisier e Mariza Pinto Coelho. 2 ed. Rio de Janeiro. Paz e Terra, 1977.

MINAYO, M. C. de S. O desafio do conhecimento científico: pesquisa qualitativa em saúde. $2^{a}$ edição. São Paulo/Rio de Janeiro: Hucitec-Abrasco, 1993.

MINAYO, M. C. (org). Pesquisa Social: Teoria, Método e Criatividade. $6^{a}$ Edição. Petrópolis: Editora Vozes, 1996. 
MINAYO, M. C. O desafio do conhecimento: pesquisa qualitativa em saúde. São Paulo - Rio de Janeiro: Hucitec-Abrasco, 1998.

MIRANDA, S. A. Educação escolar quilombola em Minas Gerais: entre ausências e emergências. Revista Brasileira de Educação, Rio de Janeiro: ANPEd; Campinas: Autores Associados, v. 17, n. 50, p. 369-498, maio/ago. 2012.

MONGA, C. Éticas dos usos do corpo. Uma teoria do amor-próprio. In: Niilismo e negritude: as artes de viver na África. Tradução de Estela dos Santos Abreu. São Paulo: Martins Fontes, 2010. (Coleção Dialética).

MOORE, C. Carlos. (Entrevista). Moore desconstrói senso comum sobre o racismo. Entrevista concedida a equipe da Imprensa da APP-Sindicato In: Revista online: GELEDES. Instituto da mulher negra. Date: 23/12/2012. In: Artigos e reflexões. Entrevista: Disponível: <https://www.geledes.org.br/carlos-moore-desconstroi-senso-comum-sobre-o-racismo/>

MOORE, C. (Entrevista). Um negro em eterno exilio. Entrevistadora: Eliane Brum. EL País (Jornal Global). Publicado em. 31 de agos. 2015. Disponível em: < https://brasil.elpais.com/brasil/2015/08/31/opinion/1441035388_761260.html>. Acesso em: 28 de agos. 2017.

MOSCOVICI, S. A representação social da psicanálise. Rio de Janeiro: Zahar. 1978.

MOURA, C. Rebeliões na Senzala, Quilombos, Insurreições, Guerrilhas. São Paulo, Ed. Ciências Humanas. 1981.

MOURA, C. Quilombos, Resistência ao Escravismo. São Paulo, Editora Ática. 1987.

MOURA, C. África \& Brasil. Revista Palmares - Fundação Cultural Palmares, Ministério da Cultura. Brasília, DF, n. 5, p. 9-15, 2000.

MOURA, G. Ilhas negras num mar mestiço. Carta: fala, reflexões, memórias. Publicação do gabinete do senador Darcy Ribeiro, Brasília 4, n.13, 1994, p.

MOURA, G. Aprendizado nas comunidades quilombolas: currículo invisível. In: BRAGA, M. L. de S.; SOUSA, E. P. de; PINTO, A. F. M. (Orgs.). Dimensões na Inclusão no Ensino Médio: mercado de trabalho, religiosidade e educação quilombola. Brasília: MEC/BID/UNESCO, 2006. (Coleção Educação para Todos).

MÜLLER, T. M. P.; Coelho, W. de N. B. A lei no.10.639/2003 e a formação de professores: Trajetórias e perspectivas. PERSPECTIVAS. Revista da ABPN, v. 5, n. 11, jul.-out. 2013, p. 29-5.

Disponível em:

em: $\quad<$

http://abpnrevista.org.br/revista/index.php/revistaabpn1/article/view/188/184> Acesso em: 17 agos. 2017.

MUNANGA, K. Origem e Histórico do Quilombo na África. In: Revista USP, nº 28, dez/fev 1995. 
MUNANGA, K. Identidade, cidadania e democracia: algumas reflexões sobre os discursos antiracistas no Brasil. Resgate, n. 6, p. 17-24, 1996.

MUNANGA, K. Rediscutindo a Mestiçagem no Brasil: Identidade Nacional versus Identidade Negra. Belo Horizonte: Autêntica, 2004a (1 $1^{\text {a }}$ ed. 1999).

MUNANGA, K. (Entrevista). A difícil tarefa de definir quem é negro no Brasil. Estudos avançados, v. 18 , n. 50, p. 51-66, 2004b. Dispinível em: <http://www.scielo.br/scielo.php?script=sci_arttext\&pid=S0103-40142004000100005>

Acesso em: 27 out. 2017.

MUNANGA, K. (Entrevista). Nosso racismo é um crime perfeito. Entrevistadores: Camila Souza Ramos e Glauco Faria, Revista Fórum, 20 nov 2012a. Disponível em: https://www.revistaforum.com.br/digital/77/nosso-racismo-e-um-crime-perfeito/ Acesso em: 20 nov 2017.

MUNANGA, K. Negritude e identidade negra ou afrodescendente: um racismo ao avesso? Revista da ABPN, v. 4, n. 8, p. 06-14.jul. out. 2012b. Disponível em: <https://www.revistaforum.com.br/2012/02/08/nosso_racismo_e_um_crime_perfeito/> Acesso em: 16 nov. 2017.

MUNANGA, K. (Entrevista). A preponderante geografia dos corpos. Entrevistadora: Leslie Chaves. In: Revista do Instituto Humanitas Unisinos (IHU- online). São Leopoldo, 16 de novembro de 2015. Edição 477 Ano XV. Disponível em: <http://www.ihu.unisinos.br/entrevistas/549024-a-preponderante-geografia-dos-corposentrevista-especial-com-kabengele-munanga>. Acesso em: 16 nov. 2017.

MUNANGA, K. As ambiguidades do racismo à brasileira. In: KON, N. M.; SILVA, M. L. da; ABUD, C. C. (Orgs.). O racismo e o negro no Brasil: questões para a psicanalise. Editora: Perspectivas, São Paulo, 2017.

MUNANGA, K.; GOMES, N. L. Para entender o negro no Brasil de hoje: história, realidades, problemas e caminhos. São Paulo: Global, 2004.

MUNANGA, K.; GOMES, N. L. O negro no Brasil de Hoje. São Paulo: Global, 2006.

MOREIRA, A. F. B.; SILVA, T. T. da. Sociologia e Teoria Critica do Currículo: uma introdução. In: MOREIRA, A. F. B.; SILVA, T. T. da. (Orgs.) Currículo, Cultura e Sociedade. São Paulo: Cortez: Editora. 1994, 7-8.

NASCIMENTO, A. do. O quilombismo: documentos de uma militância pan-africanista. Petrópolis, RJ: Editora Vozes, 1980.

NASCIMENTO, L. "Lembrança eu tenho da Saracura": Notas sobre a população negra e as reconfigurações urbanas no bairro do Bexiga. Revista Intratextos, 2014, vol. 6, nº 1, p. 25-50. DOI: http://dx.doi.org/10.12957/intratextos.2014.7099.

NETO, O. C. O trabalho de campo como descoberta e criação. In: MINAYO, M. C. de S. (Org.). Pesquisa Social: Teoria, Método e Criatividade. Petrópolis: Vozes, 1994. 
NOGUEIRA, I. B. Significações do Corpo Negro. Tese (Doutorado em Psicologia Escolar e do Desenvolvimento Humano) Universidade de São Paulo(IPUSP), São Paulo, 1998. Disponível em: <http://www.ammapsique.org.br/baixe/corpo-negro.pdf >. Acesso em: 15 nov. 2017.

NOGUEIRA, O. (1954). Preconceito racial de marca e preconceito racial de origem Sugestão de um quadro de referência para a interpretação do material sobre relações raciais no Brasil. Tempo Social, revista de sociologia da USP, v. 19, n. 1, pp. 287-308, 2006.

NORA, P. (1984) Entre memória e história: a problemática dos lugares. Tradução de Yara Aun Khoury. Projeto História. Revista do Programa de Estudos Pós-Graduados de História. São Paulo. n.10, p. 7-28, dez, 1993. ISSN 2176-2767. Disponível em: <http://revistas.pucsp.br/index.php/revph/article/view/12101>. Acesso em: 24 mar. 2017.

O'DWYER, E. C. Quilombos: identidade étnica e territorialidade. Rio de Janeiro: FGV, 2002, p. 13-42.

O'DWYER, E. C. Terras de quilombo: identidade étnica e os caminhos do reconhecimento. TOMO São Cristóvão. SE Nº 11 jul./dez. 2007.

O'DWYER, E. C. Terras de quilombo no Brasil: direitos territoriais em construção. AIRUS. Revista de Ciências Humanas e Artes ISSN 0103-9253 v. 14, n. 1/2, jan./dez., 2008.

O'DWYER, E. C. Quilombos: Os caminhos do reconhecimento em uma perspectiva contrastiva entre o Direito e a Antropologia. Fronteiras, Dourados, MS, v. 11, n. 19, jan./jun. 2009.

OLIVA, A. R. Entre máscaras e espelhos: reflexões sobre a Identidade e o ensino de História da África nas escolas brasileiras. Revista História. Hoje, v. 1, nº 1, p. 29-44- 2012.

OLIVEIRA FILHO, João Pacheco de; SANTOS, Ana Flávia Moreira. Reconhecimento étnico em exame: dois estudos sobre os Caxixó. RJ: Contra-capa/LACED, 2003.

OLIVEIRA, L. Expressões de vivência da dimensão racial de pessoas brancas: representações de branquitude entre indivíduos brancos. 2007. 137 f. Dissertação (Mestrado em Psicologia) - Faculdade de Psicologia, UFBA, Salvador, 2007.

OLIVEIRA, E. D. de. Filosofia da ancestralidade como filosofia africana: Educação e cultura afro-brasileira. Revista Sul-Americana de Filosofia e Educação. Número 18: maio-out/2012, p. 28-47.

OLIVEIRA, E. D. de. Cosmovisão Africana no Brasil: Elementos para uma Filosofia Afrodescendente. 2013.2 Disponível em: $<$ https://filosofiadaancestralidade.wordpress.com/2013/03/01/cosmovisao-africana-no-brasilelementos-para-uma-filosofia-afrodescendente-eduardo-david-de-oliveira/> .

OLIVEIRA, E. D. de. Filosofia da ancestralidade como filosofia africana: Educação e cultura afro-brasileira. Revista Sul-Americana de Filosofia e Educação. Número 18: maio-out/2012, p. 28-47. 
OLIVEIRA, E. D. Epistemologia da Ancestralidade. 2009. Disponível em: < http://filosofiaafricana.weebly.com/uploads/1/3/2/1/13213792/eduardo_oliveira_-

_epistemologia_da_ancestralidade.pdf> Acesso em: 15 nov. 2017.

OLIVEIRA, R. C. de. Identidade, etnia e estrutura social. São Paulo: Livraria Pioneira Editora, 1976.

OLIVEIRA, R. J. Segregação urbana e racial na cidade de São Paulo: as periferias de Brasilândia, Cidades Tiradentes e Jardim Angela. 2008. Tese (Doutorado em Ciências Sociais), Pontifícia Universidade Católica, São Paulo, 2008.

ORTIZ, R. A cultura brasileira e identidade nacional. São Paulo: Brasiliense, 1986.

PRANDI, R. As religiões afro-brasileiras e seus seguidores. Civitas, Porto Alegre, v. 3, nº 1, jun. 2003.

PEREIRA, J. S.; Roza, L. M. O ensino de história entre o dever de memória e o direito à história. Revista História. Hoje, v. 1, n ${ }^{\circ}$ 1, p. 89-110-2012

PEREIRA, T. H. Pele e sensibilidades: Práticas de memórias e identidades do negro na literatura (1909-1940). Dissertação (Programa de Pós-Graduação em Memória: Linguagem e Sociedade). 161f. Universidade Estadual do Sudoeste da Bahia, Vitória da Conquista, 2011. Acesso em: 16 agos. 2017. Disponível em: < http://www2.uesb.br/ppg/ppgmls/wpcontent/uploads/2017/06/Pereira-T-H.pdf> Acesso em: 12 nov 2017.

PINHEIRO, L. B. M. Negritude, apropriação cultural e a "crise conceitual" das identidades na modernidade. Universidade do Estado de Santa Catarina-XXVIII Simpósio Nacional de História-Florianópolis-SC-27-31 de julho, 2015.

PIZA, E. Porta de vidro: entrada para a branquitude. In: CARONE, I.; BENTO, M. A. S. (Orgs.). Psicologia social do racismo: estudos sobre a branquitude e branqueamento no Brasil. Petrópolis, RJ: Vozes, 2007.

POLLAK, M. Memória, esquecimento, silêncio. Revista Estudos Históricos, Rio de Janeiro, v. 2, n. 3, p. 3-15, jun. 1989. ISSN 2178-1494. Disponível em: <http://bibliotecadigital.fgv.br/ojs/index.php/reh/article/view/2278/1417>. Acesso em: 04 Mar. 2017.

POLLAK, M. Memória e identidade social. Revista Estudos Históricos, Rio de Janeiro, v. 5, n. $10, \quad$ p. 200-212, jul. 1992. Disponível em: <http://bibliotecadigital.fgv.br/ojs/index.php/reh/article/view/1941/1080>. Acesso em: 04 Mar. 2017.

POUTIGNAT, P.; STREIFF-FENART, J. Teorias da etnicidade. São Paulo: UNESP, 1998.

RAMOS, A. G. (1957). A introdução crítica à Sociologia brasileira. Rio de Janeiro. Andes.

REIS, J. J. "Escravos e coiteiros no quilombo do Oitizeiro- Bahia, 1806”. In: REIS, J. J.; GOMES, F. dos S. (Orgs.). Liberdade por um Fio: história dos quilombos no Brasil. São Paulo: Companhia da Letras, 1996, pp. 332-372. 
REIS, J. J.; GOMES, F. dos S. Uma história da liberdade. In: REIS, J. J.; GOMES, F. dos S. (Orgs.). Liberdade por um fio: história dos quilombos no Brasil. São Paulo: Companhia das Letras, 1996, pp. 9-25.

REZENDE, R. de C. Origens Africanas ou identificações mineiras? Uma discussão sobre a construção das identidades africanas em Minas Gerais do século XVIII. In: PAIVA, E. F.; IVO, I. P. (Orgs.). Escravidão, mestiçagem e histórias comparadas. São Paulo: Annablume: Belo Horizonte: PPGH-UFMG. Victória da conquista: Edições UESB, 2008. (Coleção Olhares).

ROCHA, L. M. M.; LIMA, I. de S. A História do quilombo anunciado em seu tambor: a música da nação Xambá como forma disseminadora da sua identidade cultural. In: Anais do XI CONGRESSO LUSO AFRO-BRASILEIRO DE CIÊNCIAS SOCIAIS, 2011. Disponível em: $<$ http://docplayer.com.br/15146815-A-historia-do-quilombo-anunciado-em-seu-tambor-amusica-da-nacao-xamba-como-forma-disseminadora-da-sua-identidade-cultural.html>. Acesso em: 27 nov. 2017.

ROLNIK, R. (1989) Territórios negros nas cidades brasileiras: etnicidade e cidade em São Paulo e Rio de Janeiro. In: SANTOS, R. E. dos S. (Org.) Diversidade, espaço e relações étnico-raciais: O negro na geografia do Brasil.. Belo Horizonte: Editora: Gutenberg, 2009.

ROSEMBERG, F. Psicanalise e relações raciais. In: KON, N. M.; SILVA, M. L. da; ABUD, C. C. (Orgs.). O racismo e o negro no Brasil: questões para a psicanalise. Editora: Perspectivas, São Paulo, 2017.

SANSONE, L. (Org.). Negritude sem etnicidade: o local e o global nas relações raciais e na produção cultural negra no Brasil. Tradução de Vera Ribeiro. Salvador: Edufba; Pallas, 2003.

SANTANA, G. B. B. Terras de uso comum e identidades coletivas: ressignificando o conceito e a função da propriedade. 2008. Disponível em: <http://www.ibdu.org.br/imagens/TERRASDEUSOCOMUMEIDENTIDADESCOLETIVAS .pdf> Acesso em: 20 set. 2016.

SANTOS, A. R. dos. Desenvolvimento local: mito ou realidade? O caso do pólo de confecções de Jequié/BA. Salvador, 2009. 100 f. Dissertação (Mestrado em Desenvolvimento Regional e Urbano) Universidade Salvador - UNIFACS, Salvador, 2009.

SANTOS, B. de. S. Pela mão de Alice: o social e o político na pós-modernidade. $7^{\text {a }}$ Edição. Edições Afrontamento. 1999.

SANTOS, B. de. S. (Org.) Os processos da globalização. In: SANTOS, B. de. S. A globalização e as ciências sociais. São Paulo: Cortez, 2002, pp. 25-102.

SANTOS, B. de. S. A queda do Angelus Novus: Para além da equação moderna entre raízes e opções. Revista Crítica de Ciências Sociais $\mathrm{n}^{\mathbf{0}}$ 45, Maio, 1996. Disponível em: <https://estudogeral.sib.uc.pt/handle/10316/10804>. Acesso em: 11 de junh. 2017.

SANTOS, F. Práticas Pedagógicas nas relações étnico-raciais: Identidade e memória. Revista da ABPN, v. 1, n. 3 - nov. 2010 - fev. 2011, p. 211-230. 
SANTOS, M. O espaço do cidadão. São Paulo: Editora da Universidade de São Paulo, 2007.

SANTOS, M. R. dos. Histórias de reencontro: ancestralidade, pertencimento e enraizamento na descoberta de ser negra. Dissertação (Mestrado em Psicologia Social). Instituto Psicologia da Universidade de São Paulo, São Paulo, 2014.

SANTOS, M. S. Memória coletiva: trauma e cultura: um debate. Revista USP. São Paulo, no 98, p. 51-68. Jun./jul./agos, 2013. Disponível em: < http://www.revistas.usp.br/revusp/article/viewFile/69270/71727> Acesso em: 27 nov. 2017.

SANTOS, M. W.; CRUZ, A. C. J. da. Diásporas e comunidades quilombolas: perspectivas metodológicas para o ensino de história da África e da cultura afro-brasileira. Revista História. Hoje, v. 1, no 1, p. 193-215. 2012.

SANTOS, O. S. dos. Uma viagem histórica pelas Estradas da Esperança: representações literárias do cotidiano, da região e da desativação da Estrada de Ferro Nazaré (Bahia, 19601971). Dissertação (Mestrado em História), Universidade do Estado da Bahia (UNEB). Disponível em: < http://www.ppghis.uneb.br/_dissertacoes/oscar_santana_dos_santos.pdf>. Acesso em: 06 nov 2017.

SANTOS, Y. L. dos. Além das senzalas: Arranjos escravos de moradia no Rio de Janeiro. (1880-1850). Dissertação (Mestrado em História Social). Faculdade de Filosofia e Letras. Universidade de São Paulo (USP). São Paulo, 2006.

SELIPRANDY, F. "Los rubios" e os limites da noção de pós-memória. Significação: Revista de Cultura Audiovisual, Brasil, v. 42, n. 44, p. 120-141, dec. 2015. Disponível em: <http://www.revistas.usp.br/significacao/article/view/103652>. Acesso em: 11 jun. 2017.

SEMINÁRIO VIRTUAL NACIONAL: história e cultura africana e afro-brasileira na escola / Dossiê 2014 (1.: 2012 : Florianópolis, SC). Anais do I Seminário Virtual Nacional: história e cultura africana e afro-brasileira na escola / Dossiê 2014. Florianópolis, Santa Catarina, Maio 2012 / Organizadores: Moisés Santana, Wilma de Nazaré Baía Coelho, Paulino de Jesus Cardoso, Rafael da Silva Oliveira. - Itajaí, SC: Casa Aberta, 2014.

SEPPIR. Programa Brasil Quilombola. Diagnóstico de ações realizadas em 2012. Disponível em: < http://www.seppir.gov.br/portal-antigo/publicacoes/diagnosco-do-programa-brasilquilombola-marco-de-2012-1> Acesso em: 12 nov 2017.

SILVA, A. C. da. A representação social do negro no livro didático: o que mudou? por que mudou? Salvador: EDUFBA, 2011.

SILVA, E. As Camélias do Leblon e a abolição da escravatura uma investigação de história cultural. Companhia das Letras, São Paulo, 2003.

SILVA, D. J. da. Educação Quilombola: um direito a ser efetivado. Centro de Cultura Luiz Freire. Instituto Sumaúma, PE, 2013. 
SILVA JUNIOR, M. R. da. Racismo, uma leitura. In: KON, N. M.; SILVA, M. L. da.; ABUD, C. C. (Orgs.). O racismo e o negro no Brasil: questões para a psicanalise. Editora: Perspectivas, São Paulo, 2017, p. 161-178.

SILVA, S. R. da. Quilombos no Brasil: a memória como forma de reinvenção da identidade e territorialidade negra. Artigo no XII Colóquio Internacional de Geocrítica, Bogotá, p. 1-14, maio 2012. Disponível em: http://www.ub.edu/geocrit/coloquio2012/actas/08-S-Rezende.pdf Acesso em: 27 out. 2017.

SILVA, T. D. (Texto para Discussão). Educação Escolar Quilombola no Censo da Educação Básica. Instituto de Pesquisa Econômica Aplicada - Ipea, Rio de Janeiro abril de 2015.

SILVA, T. T. (Org. Trad.). A produção social da identidade e da diferença. In. Identidade e diferença: a perspectiva dos estudos culturais. Petrópolis: Vozes, 2000. p. 73-102.

SILVÉRIO, V. R. et al. As relações étnico-raciais e a educação. In: MISKOLCI, R. (Org.). Marcas das diferenças no ensino escolar. São Carlos: EDUFSCar, 2010.

SLENES, R. W. Na senzala, uma flor: esperanças e recordações na formação da família escrava - Brasil Sudoeste, século XIX. Rio de Janeiro: Nova Fronteira, 1999.

SOUZA, M. C. C. C. de. Sob o silêncio da escola, a memória. Revista Brasileira de História, vol.17, n. 33, p. 280-292. São Paulo: Anpuh/Unijui, 1997.

SOUZA, N. S. Tornar-se negro: as vicissitudes da identidade do negro brasileiro em ascensão social. Rio de Janeiro: Edições Graal, 1983.

SOUZA, O. Fantasia de Brasil: As identificações na busca da identidade nacional. São Paulo: Editora: Escuta, 1994.

SCHUCMAN, L.V. Entre o "encardido", o "branco" e o "branquíssimo": Raça, hierarquia e poder na construção da branquitude paulistana. Tese doutorado- Programa de Pós-graduação em Psicologia. Instituto de Psicologia da Universidade de São Paulo. São Paulo, 2012, 160 f.

TEIXEIRA, L. M. P. Comunidade de Tomé Nunes: Memória e construção identitária no Alto Sertão Baiano. Dissertação (Mestrado em História). UNEB, Santo Antônio de Jesus, 2010.

TRIVIÑOS, A. N. S. Introdução à pesquisa em ciências sociais: A pesquisa qualitativa em educação. São Paulo: Atlas, 1987.

VALENTE, A. L. A lei 10. 639.03 e seus desafios. In: CUNHA, A. S. de A. (Orgs.) Construindo quilombos, desconstruindo mitos: A educação formal e a realidade quilombola no Brasil, São Luís, SETAGRAF, 2011.

WISSENBACH, M. C. Entre o sagrado e o profano: reflexões sobre o catolicismo popular e as tradições africanas no Brasil escravista e no pós-Abolição. Apresentação FEA/USP, realizada a partir da tese da autora: Ritos de magia e sobrevivência. Sociabilidades e práticas mágico religiosas no Brasil (1890-1940). Tese de Doutoramento, FFLCH/USP, 1997. Não datado.

Disponível em: 
http://brasilafrica.fflch.usp.br/sites/brasilafrica.fflch.usp.br/files/Entre\%20o\%20sagrado\%20e $\% 20 \mathrm{o} \% 20$ profano\%20Cris\%20Wissenbach.pdf> Acesso em: 21 nov 2017.

ZAMBUZZI, M. O espaço material e imaterial do Candomblé na Bahia: o que é como proteger? Dissertação (Mestrado em Arquitetura) Faculdade de Arquitetura. Universidade Federal da Bahia, 2010. 


\section{APÊNDICE A - Carta de apresentação da pesquisa}

\section{À comunidade remanescente de quilombo de Barro Preto e ao Colégio Estadual Doutor Milton Santos}

Programa de programa de pós-graduação da Faculdade de Educação da USP - FEUSP. Linha de pesquisa: Psicologia da Educação. Área de concentração: Educação para as relações étnico-raciais.

carta de apresentação à comunidade de barro preto

Viemos por meio desta carta solicitar a autorização da referida comunidade, assim como da unidade escolar inscrita em seu território, Colégio Estadual Professor Milton Santos, para realização de uma pesquisa intitulada Educação e relações étnico-raciais: Da escola ao quilombo a formação da identidade quilombola.

Sou aluna do doutorado em Educação da Universidade de São Paulo (USP), com área de interesse em Educação para as Relações Étnico-Raciais, sob a orientação da Prof. a . Doutora Maria Cecília Cortez Christiano de Souza. Em comum acordo com a minha orientadora, escolhi a comunidade quilombola de Barro Preto como campo de pesquisa.

As razões da escolha foram as ações realizadas por essa comunidade escolar para modificar o currículo escolar em virtude da sua realidade enquanto escola quilombola. A pesquisa tem como objetivo observar e analisar a proposta de educação da referida escola quilombola por meio de dados materiais e não materiais. Dentre as observações a serem realizadas, estão: Projeto Político-Pedagógico da escola entre outros materiais produzidos; os processos educativos desenvolvidos pela comunidade escolar; mecanismos de participação da comunidade nos processos educativos; percepção dos agentes escolares (professores, alunos, gestores, entre outros) com relação as experiências desenvolvidas na escola (através de entrevistas individuais e grupos focais). Pretendemos realizar entrevista também com membros da comunidade, caso seja necessário.

Certas do aceite da comunidade quilombola de Barro Preto, agradecemos antecipadamente.

São Paulo, setembro de 2015.

Aluna pesquisadora: Viviane Barboza Fernandes

vibf@usp.br

Orientadora: Prof ${ }^{a}$. Doutora Maria Cecília Cortez Christiano de Souza.

mcccs@usp.br 


\title{
APÊNDICE B - Termo de Consentimento Livre e Esclarecido
}

\author{
Educação e relações étnico-raciais: Da escola ao quilombo a formação da identidade quilombola.
}

Essas informações estão sendo fornecidas para sua participação voluntária neste estudo, que será realizado através de entrevistas individuais e aplicação de questionário. A pesquisa tem como objetivo identificar como são desenvolvidos os processos educativos na escola quilombola, buscando compreender como vem sendo conduzidas as práticas pedagógicas e em que medida elas interferem na formação e afirmação da identidade quilombola.

- Não há benefício direto ao entrevistado, pois consiste em uma pesquisa sem fins lucrativos, que será utilizada na formação (doutorado) da pesquisadora Viviane Barboza Fernandes.

- O entrevistado está suficientemente esclarecido dos possíveis riscos e desconfortos e poderão, a qualquer momento, solicitar outros esclarecimentos a esse respeito.

- Em qualquer etapa do estudo o entrevistado terá acesso ao profissional responsável pela pesquisa para esclarecimento de eventuais dúvidas. A principal pesquisadora, Viviane Barboza Fernandes, do Departamento de Pós-graduação da Faculdade de Educação da Universidade de São Paulo (FEUSP), pode ser contatada através do telefone (11) 30913519 ou do e-mail vibf@usp.br

- É garantida a liberdade do entrevistado de retirar seu consentimento a qualquer momento e deixar de participar do estudo, sem qualquer prejuízo.

- As entrevistas poderão ser gravadas (arquivos em áudio, formato digital $3 \mathrm{gpp}$ ou similar). Os registros ficarão em posse do principal pesquisador por tempo indeterminado. As transcrições, assim como os arquivos em áudio, poderão ser disponibilizados ao entrevistado, caso o mesmo os requeira.

- Ao fim do estudo, será solicitado ao entrevistado que assine o termo de cessão de direitos sobre seu depoimento oral, o que permitirá a publicação do depoimento no todo ou em parte.

- Não há despesas pessoais para o entrevistado e não há compensação financeira pela sua participação.

- Os dados e o material coletado serão usados somente para fins de pesquisa e publicação acadêmica, no Brasil ou no exterior, garantido o anonimato do participante.

\section{Declaração de consentimento}

Acredito ter sido suficientemente informado e esclarecido a respeito das informações que li, descrevendo o estudo Educação e relações étnico-raciais: Da escola ao quilombo a formação da identidade quilombola. Discuti com a pesquisadora Viviane Barboza Fernandes sobre a minha decisão em participar desse estudo. Ficaram claros para mim quais são os propósitos do estudo, os procedimentos a serem realizados, seus desconfortos e riscos e as garantias de esclarecimentos permanentes. Ficou claro também que minha participação não envolve despesas e que poderei retirar o meu consentimento a qualquer momento, durante o mesmo, sem penalidades. Concordo voluntariamente em participar desse estudo, através da assinatura do presente termo, em duas vias, ficando uma em meu poder e outra em poder da responsável pela pesquisa.

Nome do entrevistado

RG:

Declaro que obtive de forma apropriada e voluntária o consentimento livre e esclarecido do $\mathrm{Sr}$ (a)

Viviane Barboza Fernandes

RG: 33.407.037-5

de de 


\section{APÊNDICE C - Roteiro de Entrevista com as gestoras da escola}

\section{Pessoal}

1) Qual seu nome?

2) Fale um pouco sobre sua história de vida? (Sua vida aqui na comunidade).

3) A quanto tempo trabalha nesta escola?

4) O que entende por identidade quilombola?

5) Se você fosse definir Educação Escolar Quilombola, qual seria essa definição?

\section{Reconhecimento da comunidade como remanescente de quilombo}

1) O bairro foi reconhecido como quilombo em 2007. Como foi o processo de reconhecimento desta comunidade como remanescente de quilombo. Você acompanhou este processo? (Ou o que você sabe sobre isso?)

2) Dificuldades encontradas para processo de reconhecimento?

3) A comunidade participou do seu reconhecimento enquanto quilombola?

4) Como a escola vivenciou esse processo?

\section{Escola}

1) O nome da escola foi escolhido pela comunidade?

2) Os professores são oriundos da comunidade?

3) A escola tem um currículo voltado para a educação quilombola?

4) Quais são os desafios de se construir uma proposta de educação como essa?

5) As atividades contemplam elementos históricos e socioculturais da comunidade? A história de formação da comunidade contribuído com o desenvolvimento da proposta de educação? Em que medida?

6) Quais atividades (ações) vêm sendo pensadas e realizadas com intuito de valorização da cultura negra e formação da identidade quilombola?

7) Que reflexos você observa nos alunos com relação as atividades desenvolvidas?

8) O Projeto Político-Pedagógico, o currículo tem contado com a participação da comunidade?

9) Quais orientações pedagógicas para os professores da comunidade com o objetivo de se apropriarem da escola em seus aspectos políticos e pedagógicos em função da consolidação da identidade quilombola. Que cursos são realizados atualmente?

10) A escola possui um calendário escolar específico?

11) Há discussão em nível municipal em torno da lei 10.639/2003, revisão curricular da Rede municipal de Ensino?

12) Quais organizações não governamentais vem apoiando a escola atualmente?

13) De que forma a educação proporcionada pela escola vem afetando a vida dos alunos e da comunidade? 


\section{ANEXO A - Imagens da comunidade Barro Preto}

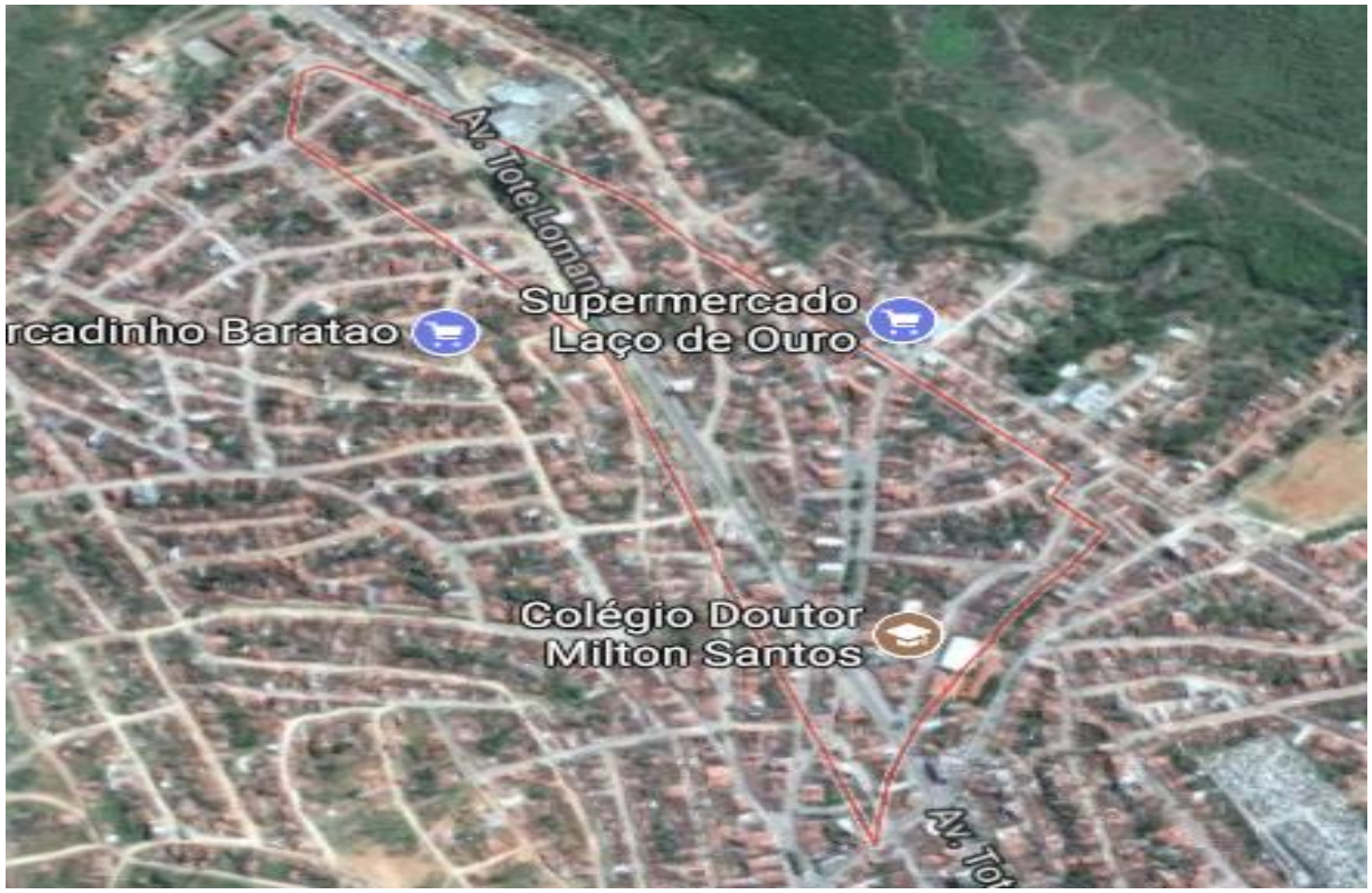

Mapa do bairro Barro Preto. Fonte: Google Mapas.

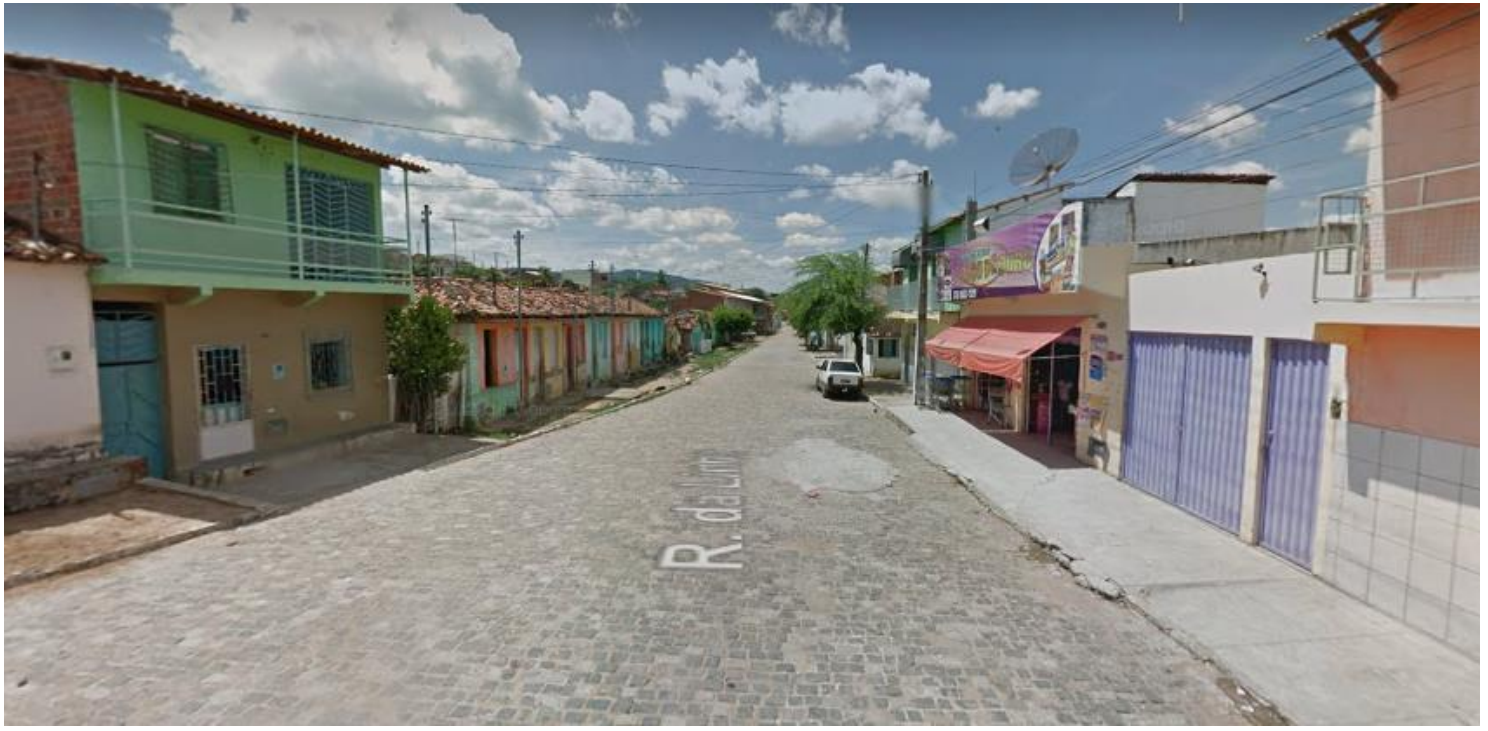

Fonte: Google Mapas. 


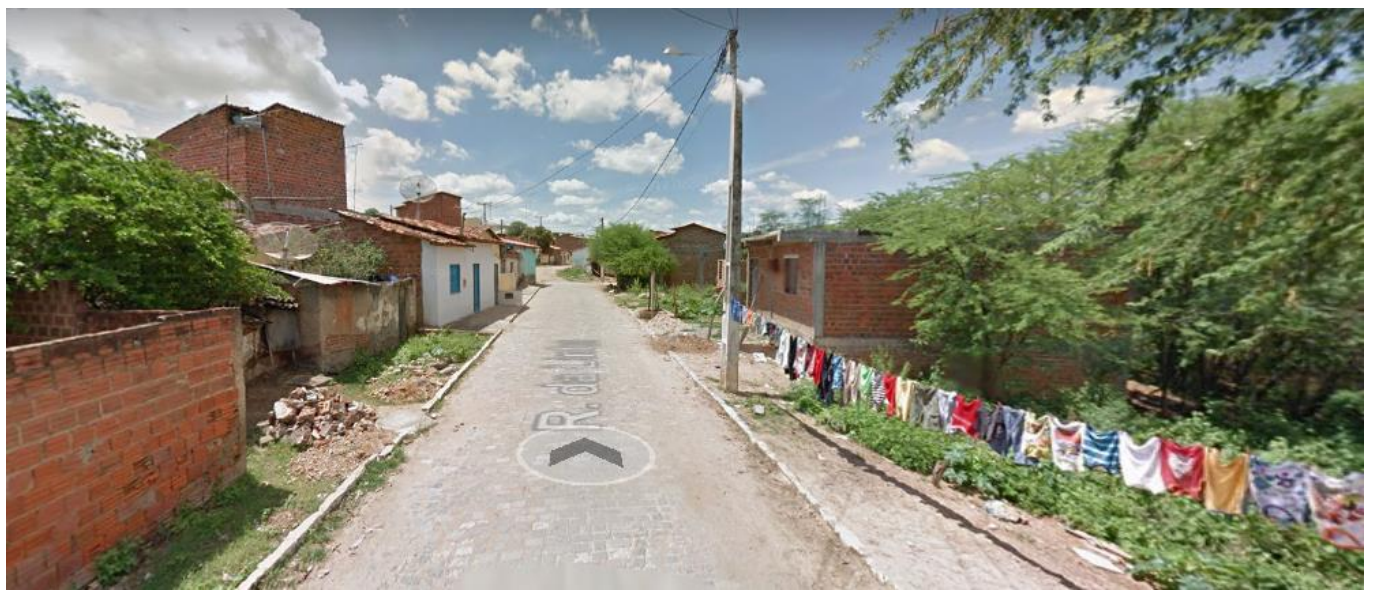

Rua da Linha. Fonte: Google Mapas.

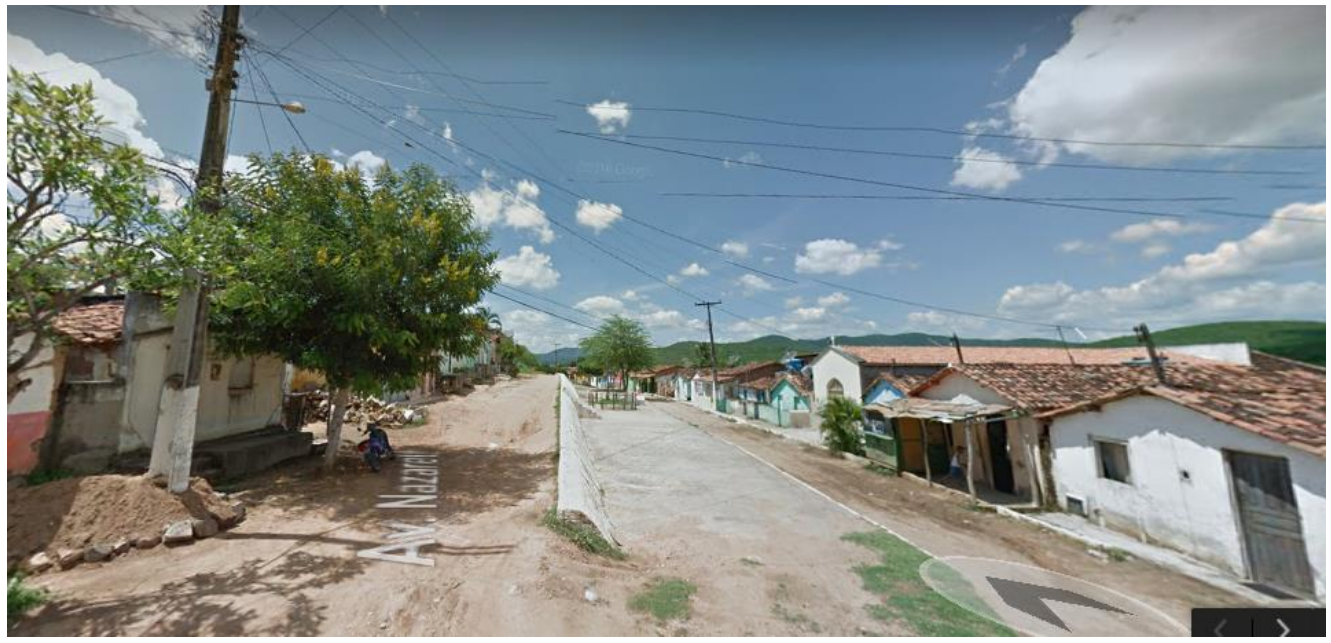

Av. Nazaré das Farinhas - Corte da Linha do Trem. Fonte: Google Mapas.

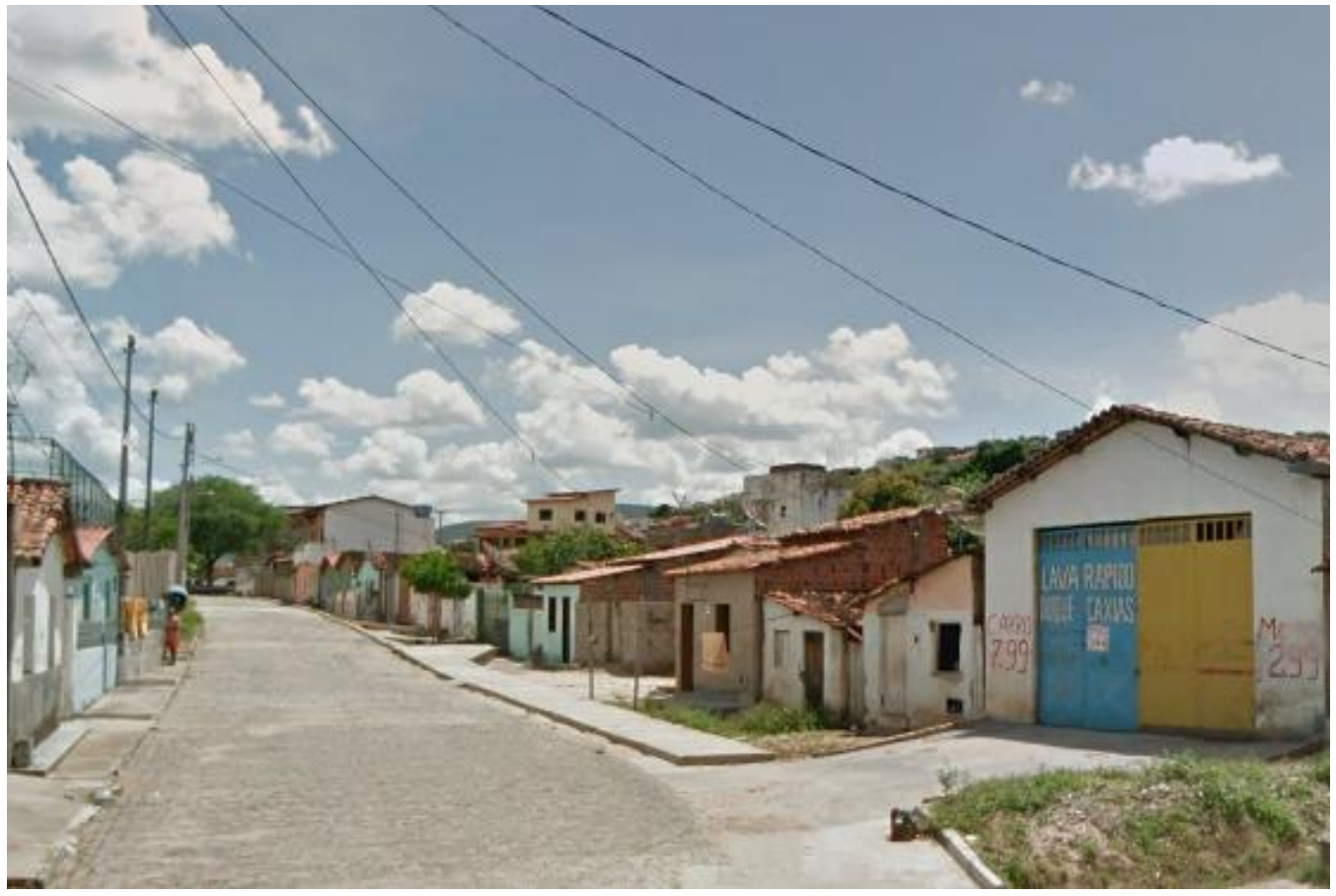

Fonte: Google Mapas. 


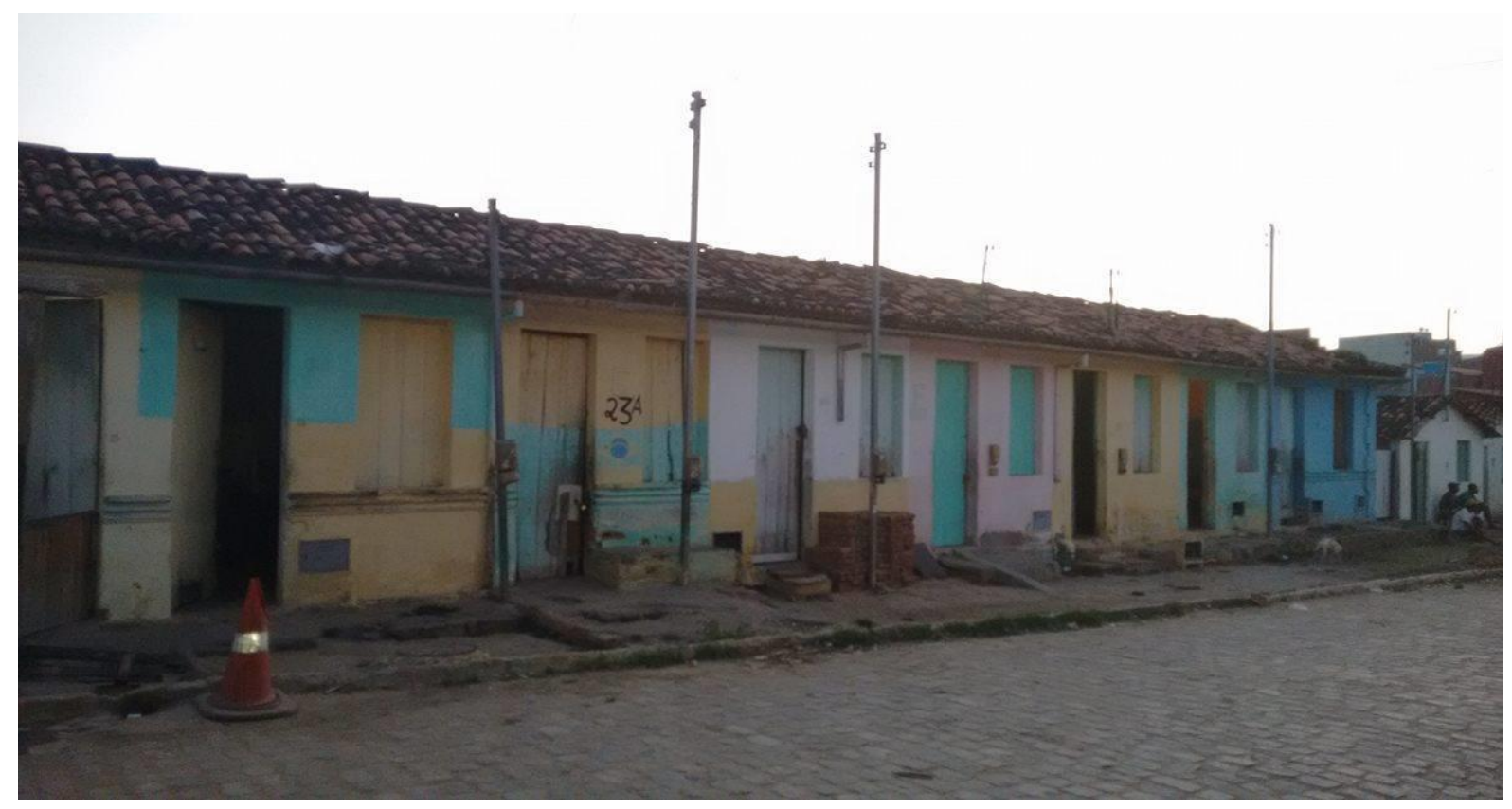

Abarracamento

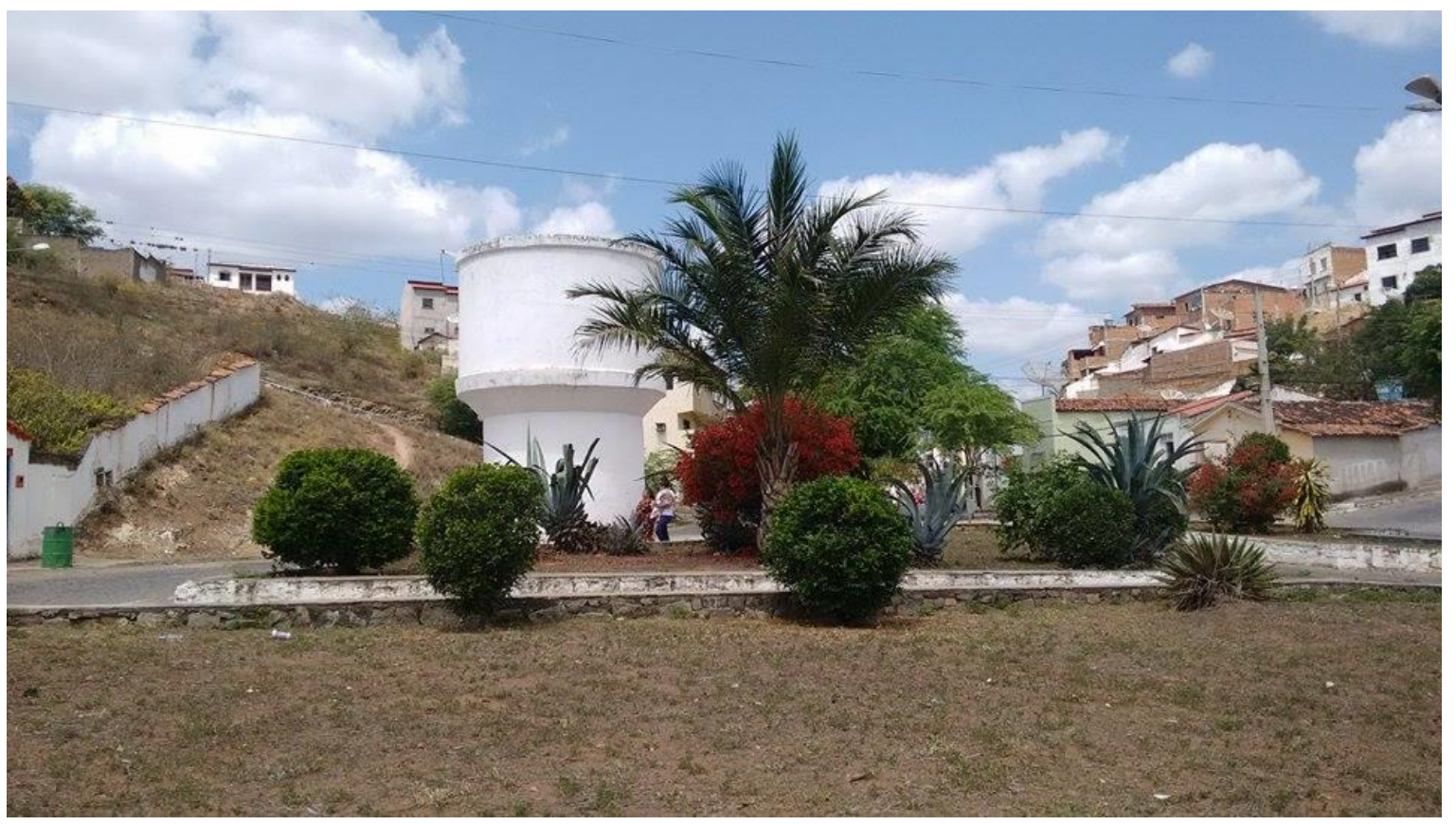

Caixa D’Água 


\section{ANEXO B - Imagens do Colégio Estadual Dr. Milton Santos}

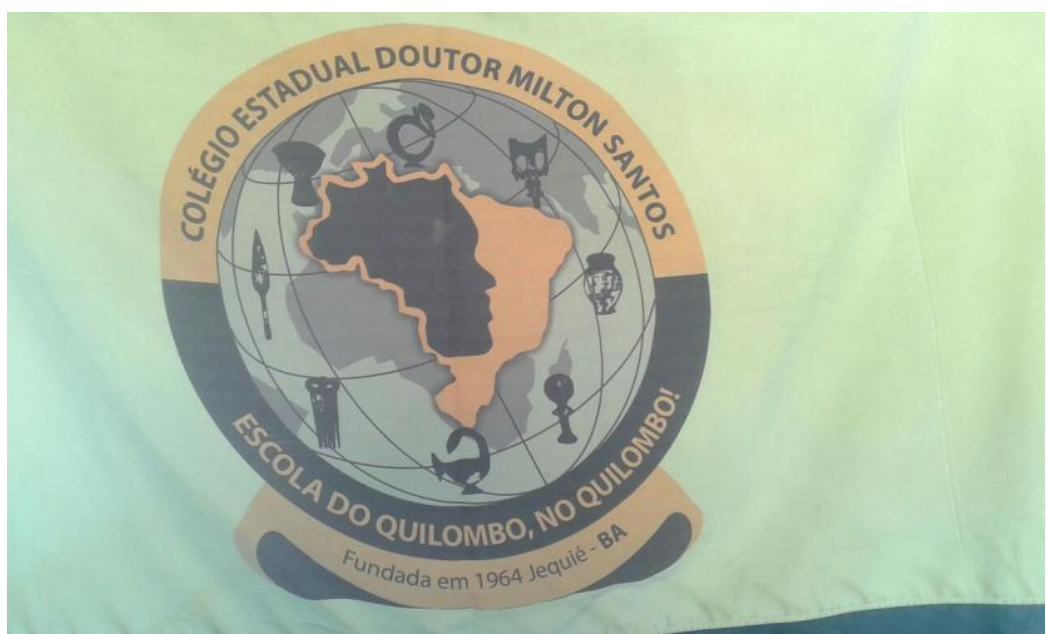

Fotografia do Brasão da Escola. Tirada por Dudu.

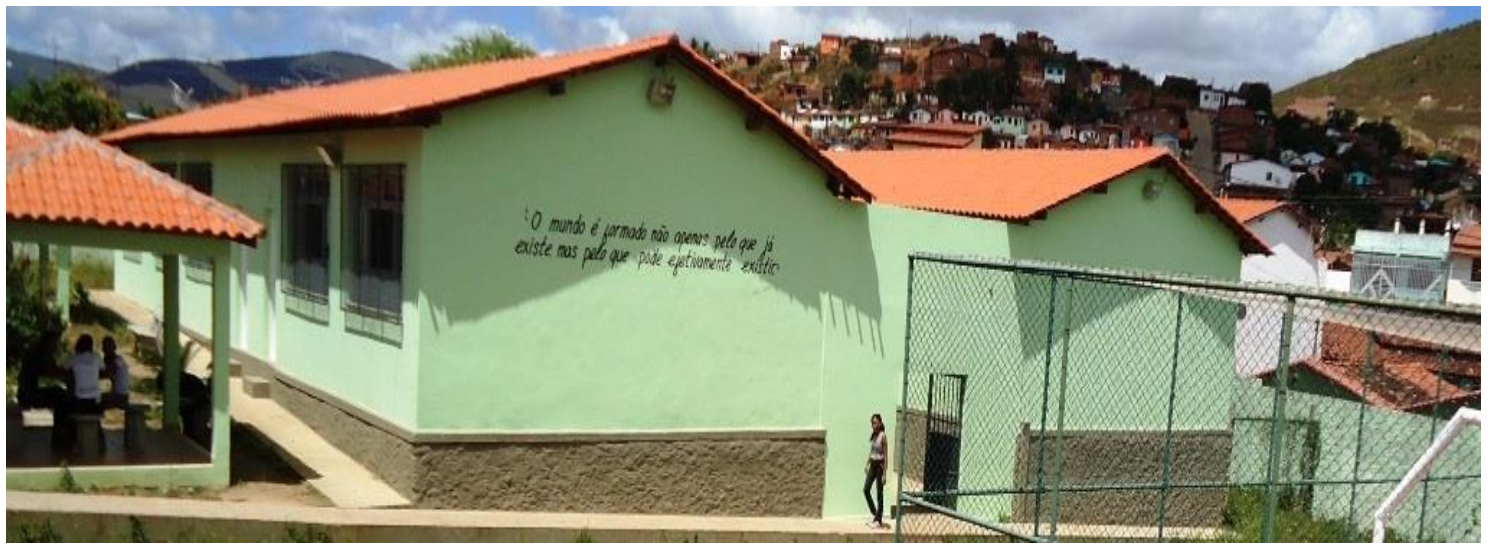

Foto da Escola. Fonte: Blog do Colégio Estadual Doutro Milton Santos. Disponível em: < http://educacaoquilombolaurbana.blogspot.com.br/>

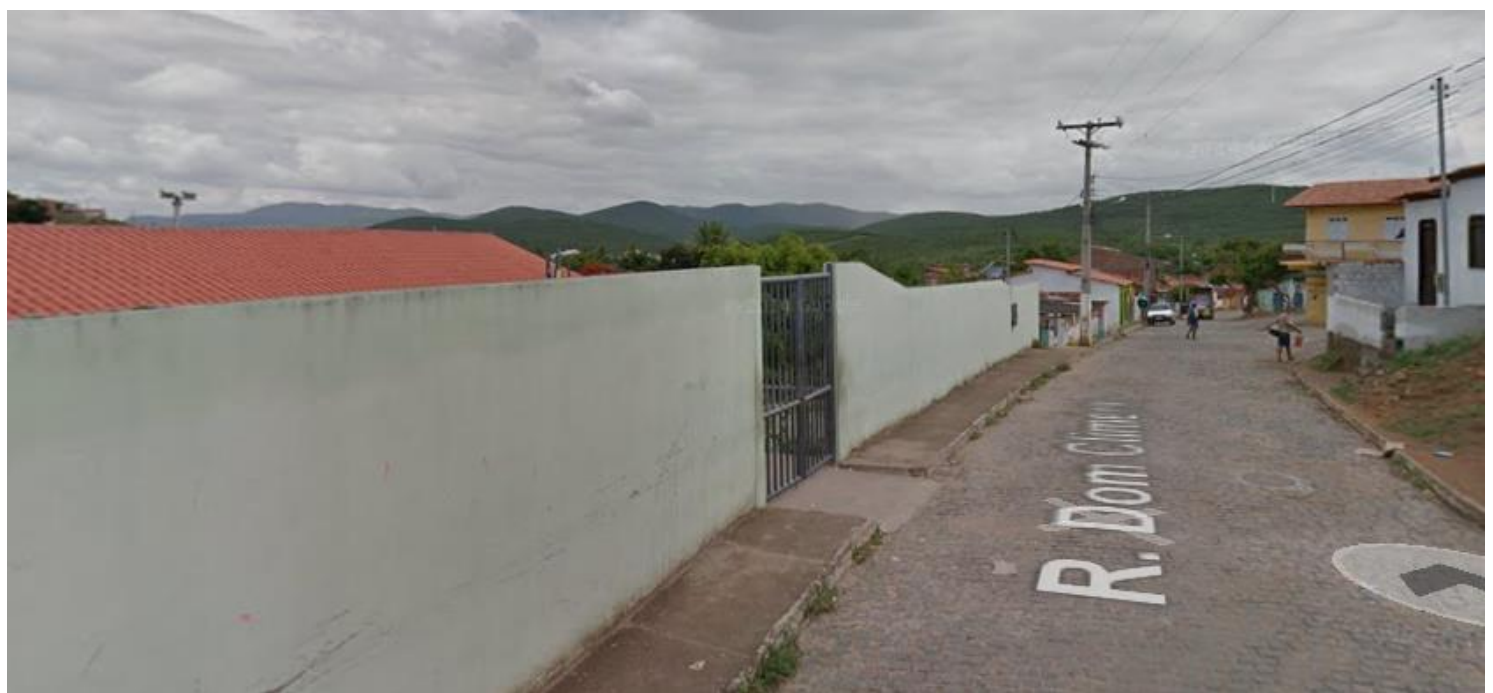

Rua da Escola: Dom Climério. Fonte: Google Mapas. 


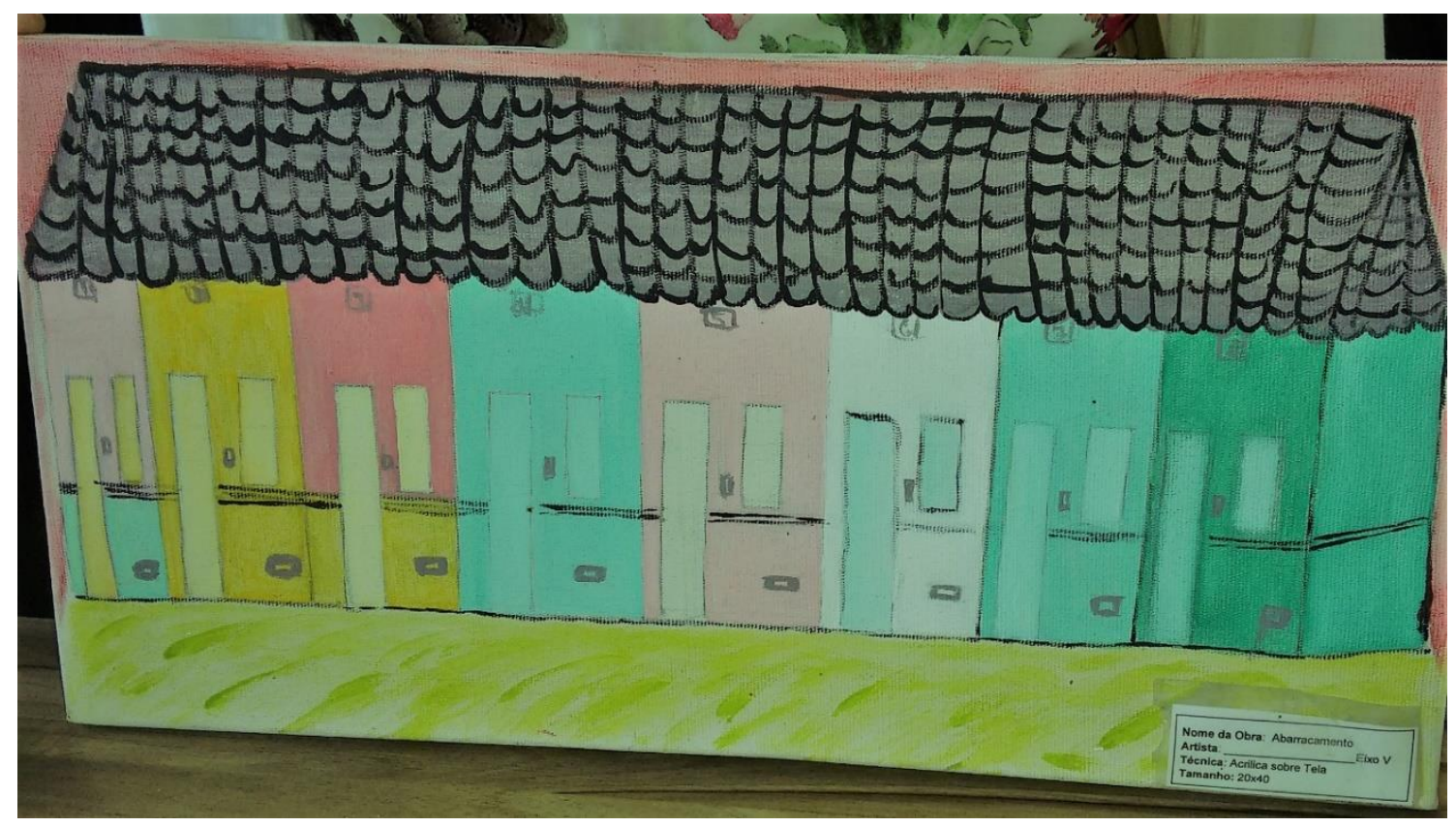

Desenho do abarracamento feito por um dos alunos.

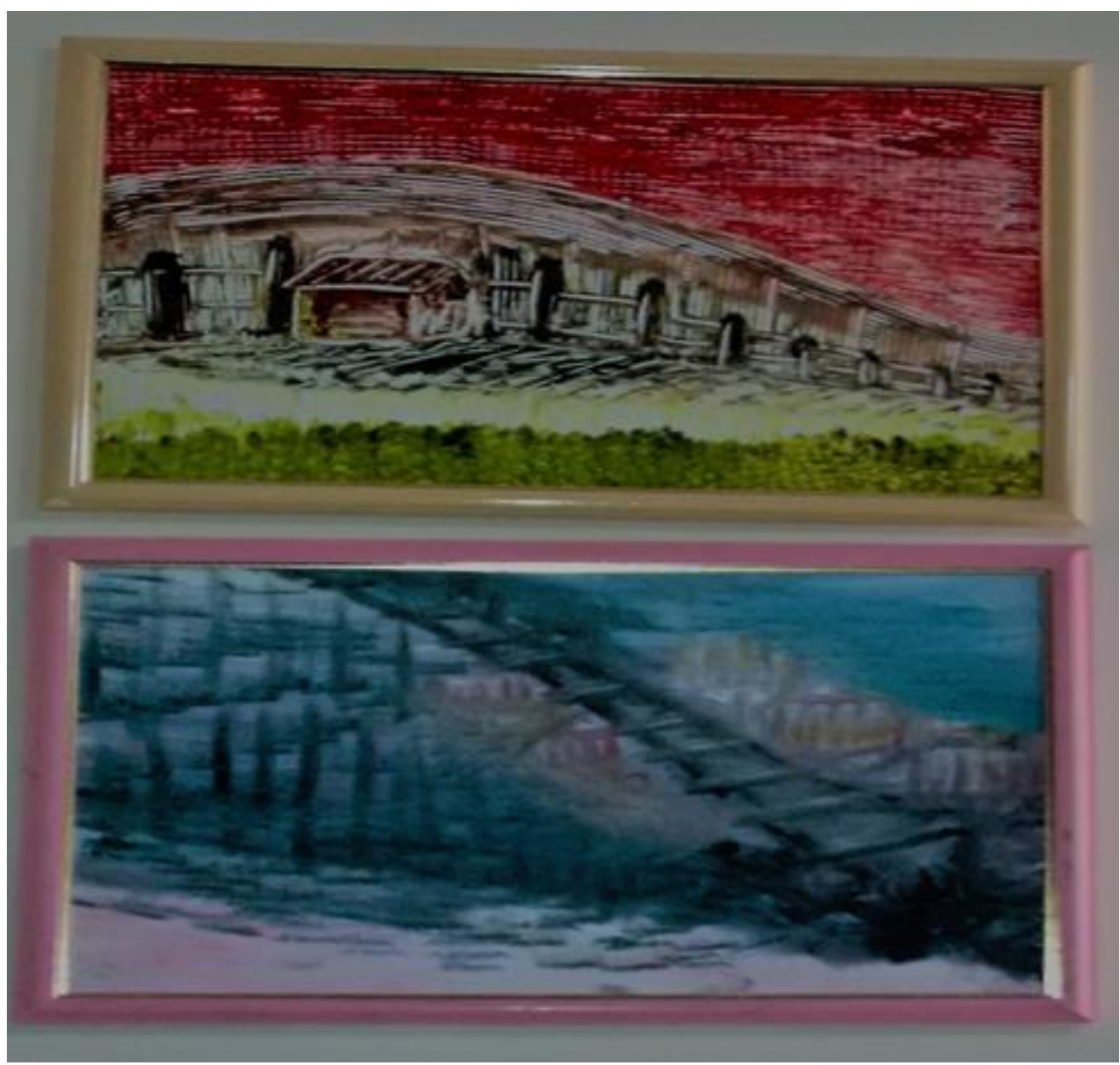

Desenhos feitos por alunos - Construção antiga e linha do trem próximas a Caixa D’Água. 


\section{ANEXO C - Certidão de reconhecimento de Barro Preto como comunidade remanescente de quilombo}

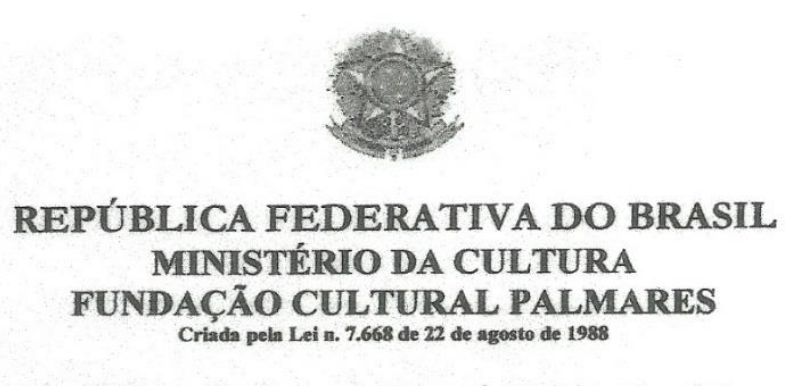

Diretoria de Proteção ao Patrimônio Afro-Brasileiro

CERTIDÃO DE AUTO-RECONHECIMENTO

O Presidente da Fundação Cultural Palmares, no uso de suas atribuições legais conferidas pelo art. $1^{\circ}$ da Lei $n .7 .668$ de 22 de Agosto de 1988 , art. $2^{\circ}, \S \S 1^{\circ}$ e $2^{\circ}$, art. $30, \S 40$ do Decreto $n$. 4.887 de 20 de novembro de 2003 , que regulamenta o procedimento para identificação, reconhecimento, delimitação, demarcação e titulação das terras ocupadas por remanescentes das comunidades dos quilombos de que trata o art. 68 do Ato das Disposições Constitucionais Transitórias e artigo 216 , I a V, $\S \S 1^{\circ}$ e $5^{\circ}$ da Constituição Federal de 1988, CERTIFICA que a Comunidade de Barro Preto, localizada no município de Jequié, Estado da Bahia, registrada no Livro de Cadastro Geral n. 09, Registro n. 919 , fl. 33 , nos termos do Decreto supramencionado e da Portaría Interna da FCP n. 06, de 01 de março de 2004, publicada no Diário Oficial da União n. 43, de 04 de março de 2004, Seção 1, f. 07, É REMANESCENTE DAS COMUNIDADES DOS QUILOMBOS.

Declarante(s):

Genivaldo Batista Santos

Presidente da Associação de Moradores do Barro Preto CNPJ n० 08.178.859/0001-05

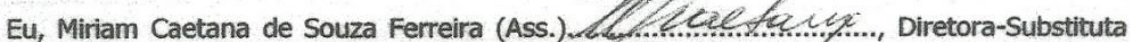
da Diretoria de Proteção do Patrimônio Afro-Brasileiro, a lavrel e a extraí. Brasilia/DF, 01 de março de 2007.

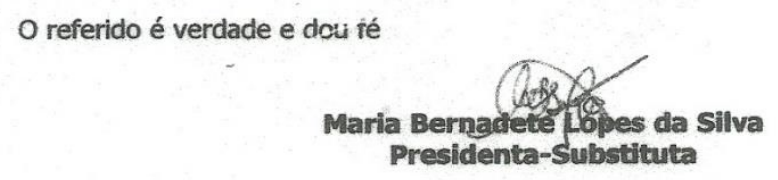

\footnotetext{
SBN Quadra 02 - Ed. Central Brasilia - CEP: 70040-904 - Brasilia - DF - Brasi Fone: (0 XX 61) 3424-0106(0 XX 61) 3424-0137 - Fax: (0 XX61) 3326-0242 E-mail:chefiadegabinete@palmares.gov.br http://wmw.palmares.gov.br

"A Felicidade do negro é uma felicidade guerreira" (Wally Salomão)
} 